\title{
The \\ Finances of the Union of South Africa
}

M. H. DE KOCB 


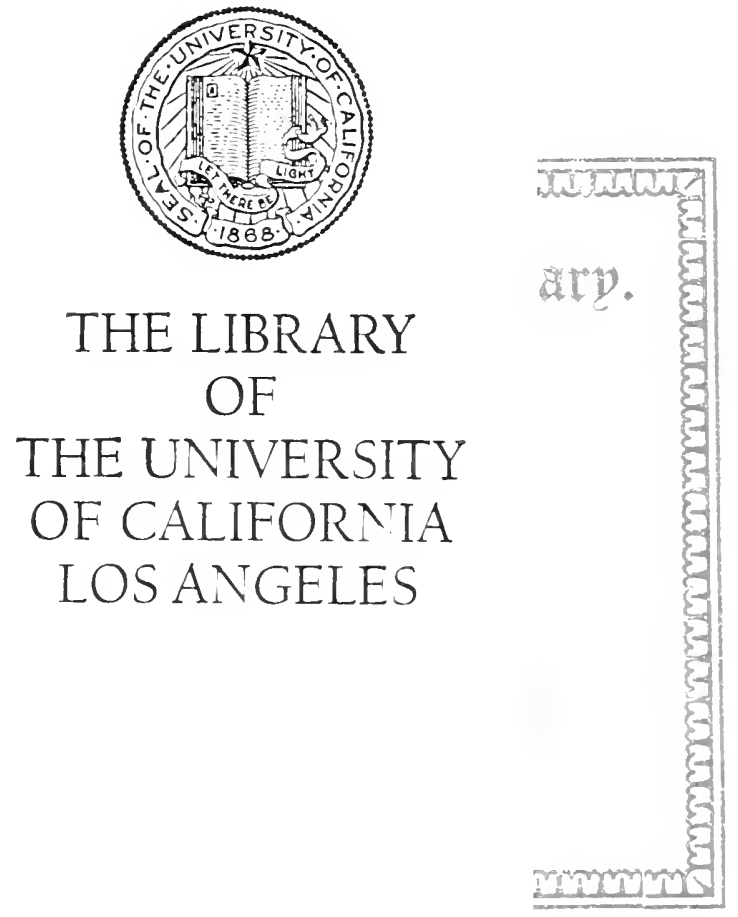


This

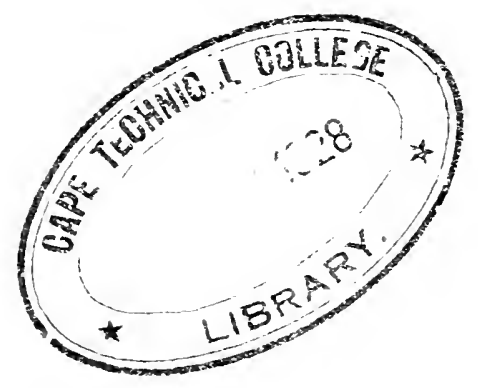





\title{
AN ANALYSIS
}

\author{
OF
}

\section{THE FINANCES OF THE}

\section{UNION OF SOUTH AFRICA.}

BY

M. H. DE KOCK,

B.A. (CAPE), M.A. and PH.D. (harvard). Senior Lecturer in Economics, Uxipersity of Cape Town.
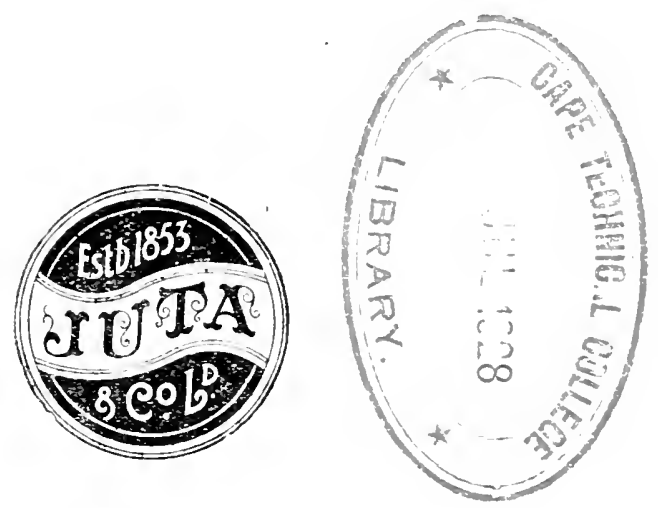

JUTA \& CO., LTD.,

CAPE town. PORt elizabeth. Uitenhage. JOHANNesburg. 1922. 
$6^{68}$

$31^{0^{0^{\circ}}}$ 


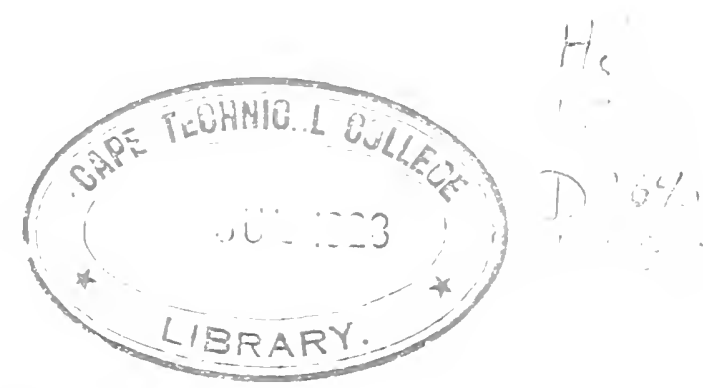

\section{PREFACE.}

This analysis of the finances of the Union of South Africa since its inception was made in partial fulfiment of the requirements for the degree of Ph.D. in Economics at Harvard University, U.S.A. As my doctoral dissertation it was confined to the period from 1910 to 1920 (the first decade of the Lnion), but before it was transmitted to the printer's the necessary alterations were made in respect of taxation and financial relations between the Union and the Provinces, in view of the important amendments introduced in 1921 and 1922. An Appendix was also added, which is intended to be a general summary of South African finance since the establishment of Union, with special reference to the financial years 1920-21 and 1921-22, thus bringing the material up to date.

The method of analysis adopted was that of scientifie economic inquiry, and the viewpoint taken was that of the economist and not of the politician or administrator. The subject of public finance is intimately connected with economics, politics, law and administration, but only economic. legal and administrative considerations have been taken into account. Politics has been relegated to the background in the attempt to discuss the financial transactions of the Union and Provincial Governments from an impartial standpoint. It has not been $m y$ aim to attribute certain actions to political motives or to trace the effects of political considerations. Where such has occurred it is to be regarded as incidental.

In accordance with custom I regard it as my duty to avail myself of this opportunity to acknowledge my indebtedness to all who have rendered any assistance to me, financially or otherwise. I wish to express herewith my gratitude and sincere appreciation of :

(1) the financial assistance in connection with my study and research work in America, rendered by (a) my father, Mr. G. P. C. de Kock, $(b)$ the Cape Helpmekaar Society which awarded me a scholarship of $£ 300,(c)$ Mr. J. Carinus, and (d) Mr. Wege, in his capacity as Manager of the Standard Bank at Malmesbury.;

(2) the helpful adrice and kindness of Professor Bullock of Harvard Cniversity: under whose guidance and supervision 
I carried out my researeh work and whose friendly critieism, valuable suggestions and words of encouragement eontributed largely towards the realization of my aims and the alleviation of $\mathrm{my}$ burdens;

(3) the co-operation of those Government officials who furnished me with the necessary reports and statistical publications (free of charge) and with the special information requested in my letter's, such as the Secretary for Finance, UnderSecretary for Finance (Mr. Middleton), Director of Census and Statistics, General Manager of Railways and Harbours, Postmaster-General, Commissioner for Inland Revenue, Assistant Controller and Auditor-General, Secretary for Lands, Chief Conservator of Forests, Superintendent of Guano Islands, etc. ;

(4) the offer of the Union Government to contribute $£ 200$ to wards the cost of publication of this treatise and of that on "Government Ownership in South Africa" in exchange for 150 copies of each, the offer having been tendered by Minister Burton;

(5) the valuable services rendered by Miss Olive Howe (of Cambridge, Mass., U.S.A.) who voluntarily undertook the arduous task of typing three copies of the original manuscript ; and

(6) the co-operation of Mr. Dunean, Manager of the firm of J. C. Juta \& Co., in connection with the publication of this book.

Finally, I wish also to utilize this opportunity to express my high regard for that valuable annual compilation of the Director of Census and Statistics known as the "Official Year Book of South Africa," which proved to be the most eonvenient source of information.

I hereby place the results of my researeh work at the disposal of the general publie with the hope that my first publication will be favourably received by the reading eommunity.

"Leeuwendans,"

M. H. DE KOCK.

Klipheuvel,

Dist. Malmesbury. 


\title{
TABLE OF CONTENTS.
}

\author{
INTROIDUCTION.
}

PART 1.

EXPENDITURES.

Chapter 1: Constitutional Expenditure.-Financial Adninistration.

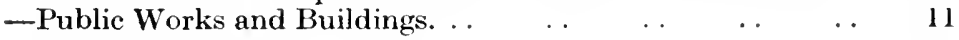

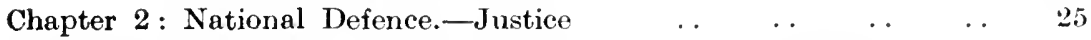

Chapter 3 : Education.-Agriculture.-Promotion and Regulation of $\begin{array}{llllllllll}\text { Industry } & \ldots & \ldots & \ldots & \ldots & \ldots & \ldots & \ldots & \ldots & 37\end{array}$

Chapter 4: Public Health.-Dependent and Defective Classes.-

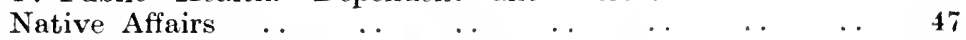

Chapter 5: Public Debt Charge.-Miscellaneous Expenditure . 52

PART 2.

REVENUES.

A. Commercial Revenues.

1. Industries.

Chapter 1: Railways

Chapter 2: Harbours.-Steamships.-Post Office, Telegraphs and

Telephones.-Land Bank .. .. .. .. .

2. Domains.

Chapter 3: Crown Lands and Land Settlement._Forestry $\quad \ldots \quad \ldots \quad \ldots \quad 93$

Chapter 4: Mining Lands and Mining Rights.-Irrigation.-Gnano

Islands $\quad \ldots \quad$.

3. Investments.

Chapter 5: Investment of Cash Balances and Deposits .. $\quad \ldots \quad 119$

B. Administrative Revenues.

Chapter 6: Fees.-Departmental Rceeipts.-Fines and Forfeitures.Rents of Government Houses and Buildings.-Miscellaneous $\begin{array}{lllllllllll}\text { Revenues . . } & \ldots & \ldots & \ldots & \ldots & \ldots & \ldots & \ldots\end{array}$ 
C. Reverees from lixatios.

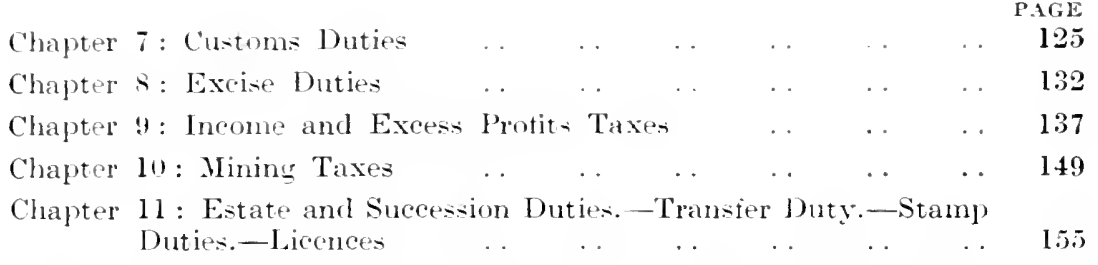

Chapter 12: Native Taxes.-Land Tax.-House Tax.-Miscellaneous

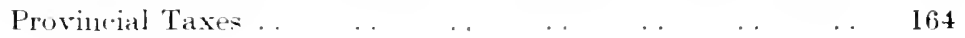

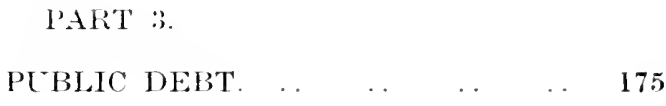

\section{PART 4.}

ADMINISTRATION AND CONTROL OF THE FINANCES.

Chapter 1: Financial Relations between the Union and the Provinces 185

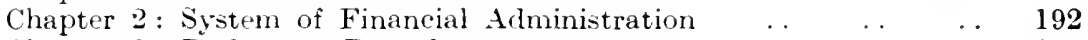

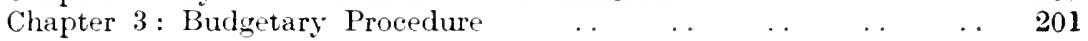

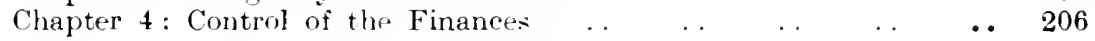

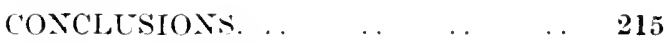

\section{APPENDIX.}

General Survey of the Finances of the Union of South Africa from 1910 to 1922 , with special reference to the financial years

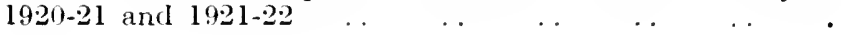




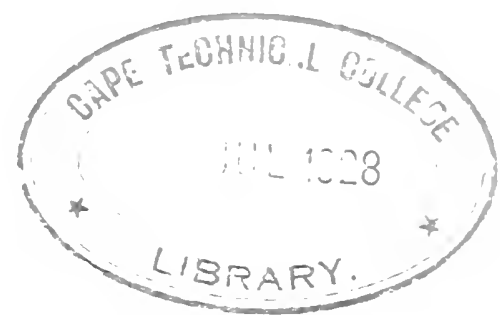

\section{THE FINANCES OF THE UNION OF SOUTH AFRICA.}

\section{INTRODUCTION.}

The Union of South Africa is constituted under the South Africa Act of 1909 (9 Edw. 7, ch. 9), which was passed by the Parliament of the United Kingdom on September 20 of that year. In terms of that act the self-governing colonies of the Cape of Good Hope. Natal, the Transraal and the Orange Rirer Colony were united on May 31, 1910, in a legislative mion under one central govermment under the name of the Union of South Africa, those colonies becoming original provinces of the Union under the names of the Cape of Good Hope, Natal, the Transval, and the Orange Free State, respectively.

The act constituting the Union provides for the appointment by the King of a Goremor-General. who, with the adrice of an Executive Council (of which the members are chosen and summoned by him), administers the exeentive govermment of the Union as the Goremor-General-in-Council." The appointment of the Governor-General by the King is merely nominal, for in reality he is appointed by the British Cabinet which happens to be in office at the time; but though appointed in this way, he is expected, as the representative of the King, to be strictly impartial and above party. ${ }^{3}$ In theory the Executive Commeil is appointed by the Gorernor-General; in practice, he sends for the recognized leader of that party which commands the majority of votes in the House of Assembly, and asks him to form a Ministry. If the Ministry can no longer command a majority in the Lower House, it has to resign, and the Governor-General then sends for someone else to form a Ministry. In short, the Executive eonsists of a Ministry formed according to the principles of responsible govermment.' The technical term adopted in the Constitution, "The GovernorGeneral-in-Couneil," means, in fact, the "Govermment."

1 S.A. Act, sec. 4.

2 Ibid., secs. 9, 12 and 13 .

3 Howes: History. Part 2. p. 394.
+ Blehy : South Africa and the British Empire, past 2. 1. 373. 
The Act also provides for the establishment of departments of state by the Governor-General in Couneil (that is, the Union Government), the Governor-General appointing not more than ten officers for the administration thereof. Such officers are ministers of state for the Union and members of the Executive Council. ${ }^{5}$ These ten ministers are known as Ministers with Portfolio-that is, administering departments of State, such as Finance, Railways and Harbours, Defenee, Agriculture-but there may, in addition, be any number of Minister's without portfolio. ${ }^{6}$

The legislative power of the Union is vested in the Union Parliament, which eonsists of the King, the Senate, and a House of Assembly. ${ }^{\top}$ The Senate has 40 nembers, of whom eight are nominated by the Govermment (four of them to be selected mainly on the ground of their thorough acquaintance with the reasonable wants and wishes of the coloured, races in South Afriea), and eight are elected for each of the four provinces of the Union. The first Senators of the latter type were elected, for a term of ten years, by joint sittings of the two Houses of the old. Colonies, and vaeancies were to be filled by the Provineial Councils of the respective Provinees. After the expiration of the ten years (1910-1920), Parliament may provide for the subsequent constitution of the Senate, but "unless and until such provision shall have been made," the eight Senators of each Province are to be elected by a joint sitting of the members of the Provineial Council and the representatives of that Provinee in the House of Assembly. The presiding officer of the Senate is a President, eleeted by the Senators from among their own number. ${ }^{8}$

The House of Assembly was to eonsist of 121 members elected directly by the people for a period of five years. At the time of the establishment of the Union the country was divided into 121 constituencies, each returning one member, distributed as follows: Cape of Good Hope 51, Transvaal 36, Orange Free State 17, and Natal 17. As the population of any province increases, its number of representatives will increase proportionately till the House of Assembly comprises 150 members, when the members will be redistributed according to the number of voters on a national basis without regard to provineial boundaries. ${ }^{9}$ The House of Assembly is presided over by a Speaker, elected by the representatives from among their own number.

\footnotetext{
5 S.A. Act, sec. 14.

Howes: History, part 2, p. 400.

B Ibid, secs. $24 \cdot 27$.

S.A. Act, sec. 19 .

${ }^{9}$ S.A. Act, secs. 32.34.
} 
The powers of Parliament, as defined in the Act of Union, are of a comparatively extensive nature. It has full power to legislate for the peace, order and good govermment of the Union." However, sinee the King is a part of the Union Parliament, its power to legislate is limited by the necessity of obtaining the King's assent to all bills before they can become law. For this purpose bills are to be presented to the Governor-General, as the King's representative.

When a bill has been passed by both Houses of Parliament, it is to be presented to the Governor-General for the King's assent, and he "shall declare according to his diseretion, but subject to the provisions of this Act, and to such instructions as may from time to time be given in that belralf by the King, that he assents in the King's name, or that he withholds assent, or that he reserves the bill for the signification of the King's pleasure." Bills dealing with certain specified matter's, such as the abolition of Provineial Councils and changes in regard to the House of Assembly, must be "reserved" by the Governor-General. Even if the GovernorGeneral has assented to a bill-and it has thus become law-the King may disallow any such law within a year thereafter. ${ }^{12}$

With regard to finance the eontrol of Parliament is eomplete. The following provisions are made in respect of Noney Bills.:-

(1) Bills appropriating revenue or moneys or imposing taxation are to originate only in the House of Assembly. But a bill is not to be taken to appropriate revenue or moneys or to impose taxation by reason only of its containing provisions for the imposition or appropriation of fines or other peeuniary penalties.

(2) The Senate may not amend any bills so far as they impose taxation or appropriate revenue or moneys for the services of the Government.

(3) The Senate may not amend any bill so as to increase any proposed charges or burden on the people. ${ }^{13}$

In this respect the position of the South African Senate is identical with that of the English House of Lords, in that neither has the power to introduce or amend any bills; they have either to accept or to reject them as they stand.

In theory the functions of the Senate, as an Upper House, are to revise and amend the laws of the Lower House, and so to serve

10 Ibid. see. 59 . In 1915 the number of constituencies was increased to 130 , and in the beginning of 1920 to 134 .

11 S.A. Act, ser. 64.
12 Ibid., sec. 65. (In such matters the King merely acts upon the advice of his Ministers.)

13 S.A. Art, sec. 60. 
in times of popular excitement as a check upon hasty legislation; and for this reason it was constituted in such a way as not to be directly controlled by the popular vote. But in practice it is not as a rule in a position to do so, owing to the late date in the session at which bills are submitted to it, and also because its members have not enough personal influence and prestige to enable it satisfactorily to discharge its functions. ${ }^{14}$

While under the Union Constitution all matters of national, or general conecrn are placed under the control of the Central Government, each Province is provided with a separate administration for the management of its local, or special, affairs. The Provincial Administrations, as constituted by the South Africa Act, are composed in each case of an Administrator, an elective Council and an Executive Committee.

The Administrator is appointed by the Union Government, for a term of five years. ${ }^{15}$ The Provincial Councils consist of the same number of members as are elected in the respective provinces for the House of Assembly, with the proviso that in any province whose representatives in the House of Assembly shall be less than twenty-five in number, the Provincial Council shall consist of twenty-five members. ${ }^{16}$ In accordance with this provision the Provincial Councils of the Orange Free State and Natal each consist of twenty-five members, whereas in the House of Assembly those two provinces are represented merely by seventeen members in cach case. The members of the Provincial Councils are elected, for a period of three years, by the parliamentary voters in the parliamentary constituencies of the Union, except in the case of the two above-mentioned provinces where additional constituericies had to be created. ${ }^{17}$ The Executive Committees consist of four persons, elected by the respective Provincial Councils, with the Administrator as chairman. ${ }^{18}$

The Provincial Councils have power to legislate by ordinance on certain subjects specified in the Act, and on such other subjects as may be delegated to it. All ordinances passed by a Provincial Couneil are suljeet to the veto of the Union Government. ${ }^{19}$

Provision was made for the appointment of a commission of inquiry into the financial relations which should exist between the Union and the provinces. This commission was to consist of one representative from each province and was to be presided

\footnotetext{
14 Howes: History, part 2, p. 396.

17 Ibid, secs. 70.71 .

15 S.A. Act, sec. 68.

if Ibid, sec. 70 .

13 Ibid, sec. 78 .

19 Ibid, sec. 90.
} 
over by an officer from the Imperial Service. Pending the completion of the inquiry, the Union Government was to pay certain sums annually out of the Consolidated Revenue Fund to the Administrator of each province.

In respect of revenues, the South Africa Act provides for the institution of $(a)$ a Railway and Harbour Fund, ${ }^{20}$ into which are to be paid all revenues raised or received by the Union Government from the administration of the railways, ports, and harbours a Consolidated Revenue Fund, ${ }^{21}$ into which are to be paid all other revenues raised or received by the Govermment; and (c) a Provincial Revenue Fund ${ }^{22}$ in every province, into which are to be paid all revenues raised by or acciuing to the Provincial Council and all moneys paid over by the Union Government to the Provincial Council.

Provision is also made for the appointment of a Controller and Auditor-General by the Govermment. This officer can only be removed by the Government when an address praying for such removal is presented. to the Governor-General by both. Houses of Parliament. The Controller and Auditor-General is to exercise such powers and functions and to undertake such duties as may be assigned. to him by the Govermment. ${ }^{23}$

The form of the South African Constitution is indicated by the official designation adopted in the Act of 1909- the Union of South Africa. It is a mion as distinguished from a federation, such as in the case of the United. States of America, the Dominion of Canada, and the Commonwealth of Australia. There is a vital difference between the two varieties. Professor Dice $y^{24}$ enunciated. the following as the three leading characteristies of foderalism: the supremacy of the constitution, the distribution among bodies with limited and co-ordinate authority of the different powers of government, and the authority of the courts to act as the interpreters of the constitution. These characteristics do not at all apply to the Union Constitution. In the first place the Parliament of the Union, and not the Constitution, is supreme. Sccondly, power is not distributed among bodies with limited and co-ordinate authority, but resides ultimately in the Parliament. Thirdly, the courts have no more authority than in Great Britain to act as interpreters of the constitution. It is from the principle of the supremacy of Parliament that flow all the fundamental differenees between a federal constitution and a unitary constitution such as

20 \& $2 \mathrm{t} \mathrm{S.A.} \mathrm{Act,} \mathrm{sec.} 117$.

22 Ibid, sec. 89.
23 Irid, sec. 132.

24 The Lraw of the Constitution, p. 136. 
that framed for South Africa. The South African Parliament is not supreme in the manner in which the British Parliament is supreme, because it is subject to the limitations which the British Constitution imposes upon all Colonial Parliaments. ${ }^{25}$ In addition, though the Union Parliament has a general power to repeal or alter the Constitution as set out in the South Africa Act, the exercise of this power is altogether withheld in respect of certain provisions, and made conditional in respect of certain other provisions, of the Act. ${ }^{26}$ But, within the Union, Parliament is supreme in the sense that there is no fetter upon its absolute freedom of action; the only restrictions are from without, namely, from the Imperia authorities. 27

It has been remarked, and justifiably too, that the unitary principle finds its most complete fulfilment in the chapter dealing with finance and railways. ${ }^{28}$ All revenues, from whatever source, over which the several Colonies had power of appropriation at the establishment of the Union, and all the railways, harbours and ports belonging to the Colonies were vested in the Central Goremment. The financial relations between the central and local governments were not subjected to a rigid definition, as in the federal constitutions of the United, States, Canada or Australia, but provision was made for an elastic system of finance by assigning the final determination of those relations to the Union Parliament, which is to effect such readjustments as altered conditions and circumstances may demand.

The establishment of the Union was prompted, in no slight degree, by the realization of the substantial economies likely to be effected by the unification of the railways, government departments and civil services of the four colonies-the substitution of one for four administrative systems. Various other factors have been enumerated, such as the consolidation of the public debts with the consequent improvement in South Afriean credit, the increased power of self-defence and self-government, the gain of that stability which attracts capital and promotes enterprise, the strength to deal with native problems, and the miformity of trade regulations. ${ }^{29}$

As a result, then, of the unification of the four colonies and the adoption of a unitary, rather than a federal, constitution, the

\footnotetext{
25 Brand: The Union of South Africa, p. 43.

26 Worsfold: The Trion of S.A.. p. 164.

27 Howes : History, part 2, p. 395.

28 Brand: The Union of S.A., p. 89.

29 Bleby : South Africa and the British Empire, part 2, p. 376.
} 
Union Government was placed in control of an extensive series of industries and domains. In view of the lack of private initiative and the small inducement to private capital in a country of vast area with a very sparse European population, the Colonies had been obliged to undertake the development of the modern facilities of transportation and communication and to promote the development of agriculture in all its aspects; so that the Union Government acquired the ownership of railways, harbours, post offices, telegraphs, telephones, savings banks, land banks, Crown lands, forests, irrigation works, guano islands, mining lands and mining rights.

The subject of this thesis, "The Finanees of South Afriea from 1910 to 1920," refers merely to national (or Union) and provincial finance and takes no account of local finance, the reason being that in South Afriea public finance resolves itself into two distinet phases-Union and Provincial finance, on the one hand, and local finance on the other-and that within the limits of a thesis justice eannot be done to both phases.

Provincial finance is virtually a part of Union finance, the two being so closely knit together as to warrant their consolidation for the purpose of scientifie analysis. In fact, the Provincial Governments were instituted primarily with a view to securing the decentralization which was considered expedient in respect of primary and secondary education, roads and bridges, hospitals and poor relief, these activities having been under the jurisdiction of the central governments of the constituent colonies.

The study of the finances of South Africa from 1910 to 1920 is of special significance in view of the many important problems involved. In the first place, the period under review represents the first decade of Union Government in South Africa, the union of the four British self-governing colonies (Cape of Good Hope, Transvaal, Orange Free State, and Natal) having been effected on the 31st May, 1910. The establishment of the Union brought about a substantial change in financial policy. The rivalry between the Colonial Governments had produced considerable development in some phases of economic life to the obvious detriment of others. On the unification of the colonies, a broad policy of general economic development was adopted, and it was decided to extend the scope of governmental activity in respect of land settlement, irrigation, forestry, agricultural credit, etc., and to undertake with vigour the extension of the railway, harbour, postal, telegraph and telephone services which had already been well developed by the colonies. 
Seeondly, the abnormal war conditions cluring one-half of the decade created new and difficult problems. The conquest of German Soutl-West Africa and the other war operations of the Union oceasioned an expenditure of about $£ 39,000,000$, of which $£ 8,000,000$ was paid out of revenue and $\$ 31,000,000$ out of loan funds. The interest on the war debt and the increase in general expenditures, as the result of the enhanced cost of living and of materials, necessitated the extension of existing forms of taxation and the introduction of new forms. The aftermath of the war presented even greater difficulties than the war itself.

Thirdly, the adoution of a unitary system of government led to the institution of provincial arlministrations with strictly subordinate powers and narrowly-confined functions. The financial relations between the Union and the Provinces were not prescribed in the Constitution, but were provided for in a legislative enactment known as the Financial Relations Act of 1913. These relations are not rigidly defined and are subject to change as altered conditions and circumstances may demand. The system of provincial government prevailing in Sonth Africa is admitted to be an experiment and may be abolisher at any time by the Union Parliament.

Method.-In general the methor adopted is that of the text book on public finance, in acrordance with which the thesis is divided into four parts :

Part 1. Expenditures:

Part 2. Revenues:

Part 3. Public Debt :

Part 4. Administration and Control of the Finances.

The expenditures are classified aceording to the activities of the Union and Provineial Governments in the following manner: constitutional expenditure (expenditure for head of state, legislature and for any other department of the Govermment the expenses of which do not fall under any of the heads of expenditure), and expenditures on financial administration, public works and buildings, national defence, justice, edneation, agriculture, promotion and regulation of industry. public health, dependent and defective classes, native affairs, public debt charge, and miscellancous serviees. The commercial expentitures are treated in Part 2 in connection with commercial revenues.

The revenues are grouped under three main heads:

(1) Commercial revenues ;

(2) Administrative revenues;

(3) Revenues from taxation. 
The commereial revemues are sub-divided into $(a)$ revenue from industries, (b) revenue from domains. and $(c)$ revenue from investments. The administrative revenues are sub-rlivided into (a) fees, (b) departmental receipts, $(c)$ fines and forfeitures, $(d)$ rents of Government houses and buildings, and $(e)$ miscellaneous revenue; and the revenues from taxation are classified according to the various kinds of taxes, such as the eustoms and excise dnties, ineome tax, excess profits tax, mining taxes, native taxes, inheritance tax, transfer duty, provineial taxes proper. stamp duties, and licences.

The public debt is analysed into its constituent elements, and an attempt has been made to determine the relation between the reproductive and the unproductive debt by ardopting the ineidence of interest eharges as a basis : that is, by ascertaining the proportion of interest which is earned by the various objects of capital outlay and that which has to be met from taxation, and applying the proportions so ascertained to the publie debt.

The subject of firancial administration and control is treated in four chapters, entitled as follows :-

(1) Financial relations between the Union and the Provinees ;

(2) System of financial administration ;

(3) Budgetary procedure ;

(4) Control of the finances. 



\section{PART I.}

\section{EXPENDITURES.}

CHAPTER 1.

Constitutional Expenditure.-Financial Administration.Public Works and Bulldings.

(1) Constitutional Expenditures.

A. Governor-General.-The Union Constitution provides for the appointment of a Governor-General as the representative of the King, and for the payment of an annual sum of $£ 10,000$ out of the Consolidated Revenue Fund as his salary. ${ }^{1}$ The annual expenditure in respect of the office of the Governor-General is about $£ 22,000$.

Fiscal Year.

1911-12

$1913 \cdot 14$

$1915 \cdot 16$

1917.18

1919-20

Expenditure on the Office of the Governor-General2

$£ 23,776$

23.784

22,762

21,298

24,804

B. Prime Minister.-The Department of the Prime Minister serves as the channel of eommunication between the GovernorGeneral-in-Council and the Departments of State, and between the Executive Council and Parliament.

Fiscal Year.

$\begin{array}{ccccc}1911-12 & \ldots & \ldots & \ldots & \ldots \\ 1913-14 & \ldots & \ldots & \ldots & \ldots \\ 1915-16 & \ldots & \ldots & \ldots & \ldots \\ 1917.18 & \ldots & \ldots & \ldots & \ldots \\ 1919-20 & \ldots & \ldots & \ldots & \ldots\end{array}$

Expenditure on Office of Prime Minister. ${ }^{3}$

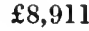

7,698

7,156

7,893

28,134

The large miscellaneous expenditure in 1919-20 is due to the contribution of $£ 16,234$ towards the expenses of the Secretariat of the League of Nations. ${ }^{4}$

C. Parliament.-The Parliament of the Union consists of two Houses, the Senate and the Legislative Assembly. The Senate is

1 S.A. Act, sees. $9-10$.

2 O.Y.B. 1918 , p. 688 , and O.Y.B. 1920.
3 O.Y.B. 1918, p. 689, and O.Y.B 1920.

4 Auditor-Genera!'s Report for 1919 .20, p. 109. 
conposed of 40 members, of whom eight are nominated by the Government and eight are clected for each of the four Provinces of the Union. The Legislative Assembly comprised 121 members during the five-year period from 1910 to 1915 and 130 during that from 1915 to 1920 . In 1920 the number of constitueneies was increased to 134 in accordance with the increase of population in the Transval. Provision is made in the Union Constitution for an annual allowance of $£ 400$ to members of the Senate and the Legislative Assembly, subject to deductions in the ease of absence."

\section{Parlanentary Expenses.}

$\begin{array}{cccccc}\text { Head of Expenditure. } & 1911-12 . & 1913-14 & 1915-16 . & 1917-18 . & 1919-20 . \\ & \mathfrak{f} & \mathfrak{f} & \mathfrak{f} & \mathfrak{f} & \mathfrak{f}\end{array}$

Allowances to Senators and Members

$\begin{array}{lllllllll}\text { of the Assembly } \ldots & \ldots & \ldots & 40,401 & 58,129 & 69,426 & 62,725 & 57,375\end{array}$

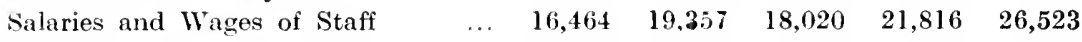

$\begin{array}{lllllllllll}\text { Hansard } & \ldots & \ldots & \ldots & \ldots & 4,000 & 5,880 & 2,280 & 418 & 1,122\end{array}$

$\begin{array}{llllllllll}\text { Miscellaneous } & \ldots & \ldots & \ldots & \ldots & 3.124 & 2,365 & 1,612 & 2,250 & 2,827\end{array}$

$\begin{array}{llllllll}\text { Total } & \ldots & \ldots & 63,989 & 85,731 & 91,338 & 91,209 & \mathbf{8 7 , 8 4 7}\end{array}$

D. Provincial Administrations,.--Each Province is provided with a separate administration for the management of its local, or special. affairs. The Provineial Administrations are composed in each case of an Administrator. an elective Council, and an Executive Committee. The salaries of the Administrators are paid by Parliament, but the allowances of the members of the Provincial Councils and of the Fxecutive Committees are paid out of the respective Provineial Revenue Funds. The Provincial Councillors receive an amnual allowance of $£ 120$. which may be reduced on aceount of absenee. ${ }^{6}$ The expenditure on the Provincial Administration has been subject to a very considerable increase, as illustrated in the following table:--

Expenditure on the Provincial Administrations.7

Head of Expenditure.

1911-12. 1913-14. 1915-16. 1917-18. 1919-20.

\begin{tabular}{|c|c|c|c|c|c|c|c|c|}
\hline \multicolumn{4}{|c|}{ Salaries and Wages of Administrative } & $\mathfrak{f}$ & f & $\mathfrak{f}$ & $\mathfrak{E}$ & $\mathfrak{f}$ \\
\hline Staffs & $\ldots$ & $\ldots$ & $\ldots$ & 53,035 & 61,701 & 72,655 & 89,686 & 130,879 \\
\hline \multicolumn{9}{|c|}{ Executive Committees and Provincial } \\
\hline Councils & $\ldots$ & $\ldots$ & $\ldots$ & 17,192 & 18,422 & 23,825 & 21,845 & 25,253 \\
\hline Transport & $\ldots$ & $\ldots$ & $\ldots$ & 3,133 & 5,803 & 7,689 & 8,948 & 12,410 \\
\hline General Expenses & $\ldots$ & $\ldots$ & $\ldots$ & 7,999 & 65,289 & 86,549 & 130,713 & 129,716 \\
\hline \multicolumn{2}{|c|}{ Total } & $\ldots$ & $\ldots$ & 81,359 & 151,215 & 190,718 & 251,172 & 342,366 \\
\hline
\end{tabular}

5 S.A. Act, sec, 56.

6 O.Y.B. 1919 , p. 156 .
7 O.Y.B. 1918, p. 705. 
The exceptional increase in expenditure in respect of the salarics and wages of the administrative staff's of the four Provinees is due to the growth of the permanent staffs from $68 \mathrm{~s}$ in 1911 to $854 \mathrm{in}$ $1918,{ }^{8}$ and to the war bonus and rise in pay. The general expenses advanced suddenly from $£ 7,999$ in 1911-12 to $£ 65,289$ in 1913-14, on account of the additional powers which were conferred on the Provincial Administrations by the Financial Relations Act ${ }^{9}$ of 1913. These powers were extended by the Finaneial Relations Extension Act ${ }^{10}$ of 1917 , occasioning still higher expenditures on the part of the Provinces in the Financial years 1916-17 and 1917-18. These general expenses include all other items which cannot be grouperl under the three great branches of provincial expenditure, namely, Education, Hospitals and Poor Relief, and Roads and Works. The total expenditure on general administration of the Provinecs shows an increase of 320 per cent., whereas the per capita expenditure, calculated with reference to the white population only, advanced 266 per cent., and that based on the total population 259 per cent.

\section{Per Capita Expenimture.}

Fiseal Year.
Expenditure per Capita Expenditure per Capita of White Population. of Total Population.

$$
\text { s. d. }
$$

$1911-12$

1915.16

1919.20

$\begin{array}{lllll}\ldots & \ldots & \ldots & 1 & 3 \\ \ldots & \ldots & \ldots & 2 & 9 \\ \ldots & \ldots & \ldots & & 4\end{array}$

$3 \cdot 2$

$11 \frac{1}{2}$

E. Department of the Interior.-The Department of the Interior is under the control of the Minister of the Interior, with the Secretary for the Interior as the permanent head. The activities of this department are of a comprehensive and discrsified nature, such as the registration of births, deaths and marriages. the management of the government printing works, the registration of voters and the conduct of parliamentary elections, naturalization, consular matters, the collection and compilation of statistics, supervision of museums, libraries, art galleries, astronomy, archives, ete., control of immigration and Asiatic affairs, supervision of government commissions, and the control of general matters affecting the Public Service other than financial control. ${ }^{11}$ These activities, apparently insignificant at first sight, constitute a substantial charge on the revenue, as evidenced by the following table:-

\footnotetext{
8 O.Y.B. 1919 , p. 111.

10 Act 9 of 1917

9 Act 10 of 1913 and O.Y.B. 1920.

11 O.Y.B. 1919, p. 106.
} 
Expanditure on 1nternat Affairs.12
Head of Expenditure.
1911-12. 1913-14. 1915-16. 1917-18. 1919-20.

\begin{tabular}{|c|c|c|c|c|c|c|c|}
\hline & & & $\mathcal{L}$ & $\mathfrak{f}$ & $£$ & $£$ & $\mathfrak{E}$ \\
\hline General Administration & $\ldots$ & $\ldots$ & 48,508 & 34,713 & 24,560 & 35,396 & 29,577 \\
\hline l'rinting and Stationery & $\ldots$ & $\ldots$ & 250.183 & 227,809 & 173,082 & 245,755 & 328,631 \\
\hline Immigration and Asiatie Af & fairs & $\ldots$ & 17.602 & 17,127 & 22.553 & 22,791 & 23,236 \\
\hline Registration of V'oters. and & Eleetio & ins & - & 17,448 & 17,465 & - & 36,887 \\
\hline C'ensus and Statisties & $\ldots$ & $\ldots$ & 102,508 & 10.221 & 6,385 & 13,162 & 41,047 \\
\hline Commissions $\ldots$ & $\ldots$ & $\ldots$ & 17,996 & 20.538 & 17,007 & 12,050 & 29,719 \\
\hline Libraries and Mnsenms & $\ldots$ & $\cdots$ & 39,707 & 31,807 & 22,524 & 26,420 & 27,879 \\
\hline Meteorology and Astronomy & & $\ldots$ & 6,399 & 4,958 & 6,460 & 6,188 & 4,983 \\
\hline Total & & & 482,903 & 364,621 & 290,036 & 361,762 & 521,959 \\
\hline
\end{tabular}

The expenditure on internal affairs illustrates the tendency, perceptible in connection with several items of expenditure, of a steady deerease after the establishment of Union, as the result of the economies effected by the consolidation of four Colonial departments into one Union department, until the bcginning of the war period which oceasioned a sudden decline, in view of the shrinkage of eertain sources of revenue affected by the war. The high mark of 1911-12 is due to the large appropriation for the extensive census which was undertaken during that year. If the expenditure in respeet of eensus and statisties had been normal in that year, the decrease in the following year would have been comparatively small.

'The first year of the war, however, presented a decline of about 15 per cent. over the expenditure of the precerling year. and the second year witnesiad a further decline. Subsequent to that the expenditure was subject to an advance again, due to the increased cost of living. The introduction of the general war bonus in 1918 and of the general rise in salaries and wages in 1919 oceasioned a considerable advance in the public expenditure-an increase of about 45 per cent. in 1919-20 as compared with 1917-18. This feature will be olserved in virtually every branch of expenditure in the aforegoing table, the vear $1917-18$ showing an increase in expenditure over that of the precerling year, and the year 1919-20 again over that of 1917-18. These branches of expenditure afford excellent scope for retrenchment in the case of an emergeney, without unche sacrifice.

In the matter of printing and stationery. the war reductions were made principally in "contract printing and binding" and in "stationery," the former declining from $£ 50,800$ in 1913-14

12 O.Y.B. 1918, P1) 687, 689, and 694, and O.Y.B. 1920. 
to $£ 43,051$ in $1914-15$ and $£ 25,146$ in $1915-16$, and the latter from $£ 50,690$ in $1913-14$ to $£ 39,565$ and $£ 36,809$, respectively, in the two following years. ${ }^{13}$ The expenditure on salarics and wages constitutes on the average about onc-third of the total expenditure on printing and stationery. This was only slightly lowered during the earlier part of the war period.

The per capita expenditure in respect of printing and stationery is considerable. Taking the financial year 1912-13 as a normal year and assuming that the white population very closely approximates the appropriate basis of computation, it is found that the per capita.figure is as high as $3 \mathrm{~s}$. $6 \mathrm{~d}$.

As to immigration and Asiatic affairs, the high peak of $1916-17$ is due to an appropriation of $£ 10.212^{14}$ for the repatriation of Asiatics.

The irregularity in the case of the expenditure on the registration of voters and on elections is to be ascribed to the absence or presence of a general election, the high figures of 1913-14, 1915-16 and 1919-20 being accounted for by the provincial or national elcctions.

The abnormal expenditure of $\$ 102.508$ in 1911-12 in connection with the collection of statistics was caused by the great census that was undertaken in that year. A central statistical office for the Union was established on April 1, 1917, with the Director of Census as the administering officer and a Statistical Council of eight members, in accordance with the provisions of the Statistics Act ${ }^{15}$ of 1914 .

The expenditure shown under the heading of Commissions includes the salaries of the members of the Public Service Commission and staff, together with incidental expenses. Provision was made in the Union Constitution for the appointment of this Public Service Commission, in which was vested the control of the appointment, discipline, resignation and superannuation of Government officials. ${ }^{16}$ In addition to this there are Statutory, Parliamentary and Departmental Commissions. ${ }^{17}$

The expenditure on libraries and museums takes the form of grants by the Union Govermment, these grants serving as the most important source of revenue in the case of museums-in some cases almost the sole source, as with the South African Museum at Cape Town, the revenue of which in 1917-18 was composed of a government grant of $£ 4,200$ and $£ 417$ from other sources. ${ }^{18}$

13 O.Y.B. 1919 , p. 847.

14 Ibid, p. 846 .

15 Act 38 of 1914 .
16 S.A. Act, sec. 142.

17 O.Y.B. 1919 , p. 848.

18 Ibid, p. 312. 
As regards meteorology and astronomy, the Transvaal Observatory, which had been established in 1903 by the Transvaal Government, was taken over by the Union Government and renamed the "Union Obscrvatory" by government proclamation ${ }^{19}$ in 1912, under the direction of the Astronomer of the Union. It is the official astronomical and meteorological station in the Union. ${ }^{2}$

F. Civil Pensions.- The Public Service and Pensions Act ${ }^{21}$ of 1912 provides for the establishment of three pension funds:-(1) the Administrative and Clerical Division Pension Fund; (2) the General Division Pension Fund ; and (3) the Defence, Police and Prisons Pension Fund. Each fund consists of $(a)$ contributions by members of the Public Service and $(b)$ contributions by the Government.

The Government contributions compriee the following:-(1) a sum equal to the aggregate of the current contributions made by officers to their respective funds; (2) various minor contributions relating to special cases; and (3) interest at the rate of $3 \frac{1}{2}$ per cent. per annum on the daily average uninvested balances of the funds. ${ }^{22}$

The Public Service and Pensions Act imposes five additional charges on the public revenue in respect of pensions and gratuities. In the first place, if a member of the public service is obliged to retire therefrom owing to severe bodily injury or permanent illhealth occasioned without his default in the discharge of and specially attributable to his official cluties, the Government is to grant him a pension varying according as his capacity to contribute to the support of himself and his dependents is materially impaired or totally ilestroyed. ${ }^{23}$

Secondly, if a member of the public Service loses his life as the result of an injury or an illness contracted under the aforementioned circumstances, whether reath occurs immediately or within one year after the injury or commencement of the illness, the Government is to grant his widow or children, or father, mother, brother or sister dependent upon him for support and maintenance, such annuity or gratuity as the necessities of the case may require. If any such member had contributed to the pension fund of his division, the amount of the contributions made by this member and the amount paid from revenue to the fund in respect of such member, together with interest at the rate of $3 \frac{1}{2}$ per cent. per annum, are (i) be repaid to revenue out of the fund.. ${ }^{24}$

\footnotetext{
19 Govt. Notiec No. (1!2 (1.5.12).

20 O.Y.B. 1919, p. 71.

it $1 \mathrm{C}^{2} 29$ of 1912 .

22 Act 29 of 1912 , sec. 26 .

23 Ibid, secs. 46 and 49 .

$24 \mathrm{Ibid}$, secs. 47 and 50 .
} 
Thirdly, an officer who has contributed to the pension fund of his division in respect of a period of 10 year's or more is, if discharged from the Public Service owing to the abolition of his office or a reorganization or readjustment of departments or offices in the Public Service, entitled to an annuity calculated at the rate of one-sixtieth of his average pensionable emoluments for each year of contribution. The payment of any such annuity before the officer concerned attains the age of sixty years is to be made from revenue and not from the fund, but after he attains that age such payments are made out of the fund. ${ }^{25}$

Fourthly, an officer who has attained the age of 55 years may be required to retire on pension, but all annuities paid before that officer is entitled to retire at the age of 60 are to be charged to revenue and not to the fund. ${ }^{26}$

Finally, an officer who has continuously occupied, for at least ten years immediately preceding retirement, an office or post in a leper or lunatic asylum or in a govermment institution used for the treatment of infectious or contagious diseases and who comes in daily contact with patients suffering from leprosy, lunacy, or such diseases, is entitled to retire on pension on attaining the age of 50 years and to have a period of five years added for the purpose of calculating his pension upon his retirement, so much of the pension as is attributable to the added service being paid out of revenue. ${ }^{27}$

As a result of the elaborate pension system prevailing in the Union, the expenditure in regard to eivil pensions and gratuities constitutes quite a heavy charge on the public revenue. as testified by the table $e^{28}$ on the following page.

The sudden increase in the expenditure in 1912-13 as compared with that in the preceding year is due to the coming into effect of the Public Service and Pensions Act on August 1, 1912, which entailed larger contributions by the Government, and also to the reorganization of the Government departments, which occasioned a higher compensation charge.

\footnotetext{
25 Act 29 of 1912 , sec. 32 .

28 O.Y.B. 191S, p. 691 ; O.Y.B. 1919

26 Ibid, sec. 30 (2).

27 Ibid, sec. $30(3)$. p. 848; and Appropriation Accounts, $1919-20$.
} 
Expenditure on Civil Pensions.

Heading. 1911-12. 1912-13. 1914-15. 1917-18. 1919-20.

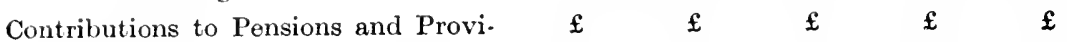

$\begin{array}{lllllllll}\text { dent Funds } & \ldots & \ldots & \ldots & \mathbf{7 4 , 9 8 5} & 114,866 & \mathbf{8 8 , 0 7 4} & \mathbf{1 1 6 , 6 4 7} & \mathbf{1 3 0 , 4 3 9}\end{array}$

$\begin{array}{llllllll}\text { Compensation Allowances } & \ldots & \ldots & 137,779 & 162,281 & 141,980 & 128,828 & 121,362\end{array}$

$\begin{array}{llllllll}\text { Superannuation Allowances } & \ldots & \ldots & 102,434 & 107,284 & 105,924 & 127,359 & 138,142\end{array}$

$\begin{array}{llllllllll}\text { Invalid Allowances } & \ldots & \ldots & \ldots & 51,330 & 53,139 & 60,083 & 66,940 & \mathbf{7 8 , 7 7 1}\end{array}$

$\begin{array}{llllllll}\text { Miscellaneous Allowances } & \ldots & \ldots & 22,984 & 25,269 & 22,714 & 23,973 & 280,925\end{array}$

$\begin{array}{lllllllll}\text { Totals } & \ldots & \ldots & 389,512 & 462,839 & 418,775 & \mathbf{4 6 3 , 6 4 7} & \mathbf{7 4 9 , 6 3 9}\end{array}$

The large miscellaneous expenditure in 1919-20 is due to the inclusion of the estimated deficit of $£ 250,000$ on the Transvaal Administrative and Clerical Service Pension Fund. 29

\section{Per Capita Expenditure.}

Fiscal Year.

$1911-12$

$1914-15$

$1919 \cdot 20$
Expenditure per c.spita of the white popuation.

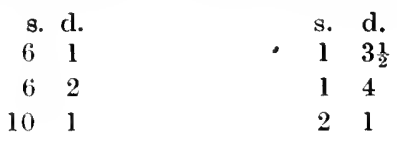

\section{G. High Commissioner and Trades Commissioner.-The High} Commissioner for the Union of South Africa, who is stationed at London, is the representative of the Union Government in the United Kingdom for such purposes as may be required. He serves as a general agent for the Union in London in financial, eommereial and other matters. The Trarles Commissioner, again, is charged with the supervision and direction of the trade interests of the Union in the United Kingdom and elsewhere. ${ }^{30}$

The expenditure on the offices of the High Commissioner and the 'Trades Commissioner likewise presents an example of minimum expenditure in the first two years of the war, followed by a substantial increase toward the end of the deeade.

Expenditure on the High Commissioner and Trades Commissioner. 31

Service.

High Commissioner

1911-12. 1913-14. 1915-16.1917-18. 1919-20.

$\mathfrak{f}$

'Trades Commissioner...

Total

29 Appropriation Accounts, 1919-20.

30 O.Y.B. 1919, p. 105.
31 O.Y.B. 1918, p. 690 , and O.Y.B. 1920. 


\begin{tabular}{|c|c|c|c|}
\hline \multirow[b]{2}{*}{ Fiscal Year. } & \multicolumn{3}{|c|}{ Sumary of Constitutional Exienditure. } \\
\hline & $\begin{array}{c}\text { Total } \\
\text { Constitutional } \\
\text { Expenditure. }\end{array}$ & $\begin{array}{l}\text { Expenditure per } \\
\text { capita of White } \\
\text { Population. }\end{array}$ & $\begin{array}{l}\text { Expenditure per } \\
\text { capita of Total } \\
\text { Population. }\end{array}$ \\
\hline & $\mathfrak{£}$ & E s. d. & s. d. \\
\hline 1911.12 & $1,085,617$ & $\begin{array}{llll}0 & 16 & 11\end{array}$ & 37 \\
\hline $1913-14$ & $1,099,436$ & $\begin{array}{lll}0 & 16 & 6\end{array}$ & $\begin{array}{ll}3 & 6\end{array}$ \\
\hline $1915-16$ & $1,080,705$ & $\begin{array}{llll}0 & 15 & 8\end{array}$ & $\begin{array}{ll}3 & 4\end{array}$ \\
\hline 1917.18 & $1,227,015$ & $\begin{array}{llll}0 & 17 & 0\end{array}$ & $\begin{array}{ll}3 & 7\end{array}$ \\
\hline $1919 \cdot 20$ & $1,809,510$ & 146 & $5 \quad 1$ \\
\hline
\end{tabular}

\section{(2) Financial Administration.}

The Department of Finance is placed under the control of the Minister of Finance, who is responsible to Parliament. The Secretary for Finance is the permanent head of the Department, the functions of which permit of the following sub-division: (1) the Treasury, (2) the department of Inland Revenue, (3) the department of Customs and Excise, and (4) the department of the Controller and Auditor-General.

The general control of the finances of the Union (excepting the finances of the Railway and Harbour Administration) is vested in the Treasury. It is charged with the performance of all duties relating to appropriation and supply (except for the services of the Railway and Harbour Administration), with the regulation of the financial relations between the Union Government and the Provincial Administrations, the raising and management of loans, the payment of pensions and gratuities, the supervision of banking institutions and the regulation of the currency.

The department of Inland Revenue is concerned with the imposition, assessment and collection of revenues other than customs and excise, these being assigned to the department of Customs and Excise, which is also charged with the registration of shipping and the protection of the publie from adulterated food and drink in respect of imported goods. ${ }^{32}$

The department of the Controller and Auditor-General exercises control over the issues from the Exchequer. It is also entrusted with the audit of the public accounts, including those of the Railway and Harbour Administration, and with the preparation of a report. to Parliament on the results of the audit. The office of Controller and Auditor-General was created by the Union Constitution. ${ }^{33}$ Under this heading is included the expenditure for the audit of provincial accounts, for which likewise provision is specifically

O.Y.B. 1919, p. 105.

33 S.A. Act, sec. 132. 
made in the South Africa Act. ${ }^{34}$ In each Province there is an auditor of accounts appointed and paid by the Union Government.

A tabular presentation of the financial expenditures will serve to illustrate a combination of the various tendencies in South African finance during the period under eonsideration.

Expenditures on the Financial Administration. 35 1911-12. 1913-14. 1915-16. 1917-18.1919-20.

\begin{tabular}{|c|c|c|c|c|c|c|c|c|}
\hline Treasury & $\cdots$ & $\ldots$ & $\ldots$ & $\begin{array}{c}\mathfrak{E} \\
47,643\end{array}$ & $\begin{array}{c}£ \\
43,370\end{array}$ & $\begin{array}{c}£ \\
39,532\end{array}$ & $\begin{array}{c}£ \\
38,503\end{array}$ & $\begin{array}{c}\mathfrak{E} \\
52,927\end{array}$ \\
\hline Inland Revenue & $\ldots$ & $\ldots$ & $\cdots$ & 35,077 & 27,705 & 39,482 & 53,968 & 82,541 \\
\hline Customs and Excise & $\ldots$ & $\ldots$ & $\ldots$ & 158,252 & 145,274 & 138,082 & 146,604 & 183,375 \\
\hline Auditor-General & $\ldots$ & $\ldots$ & $\ldots$ & 52,939 & 46,276 & 38,529 & 52,710 & 62,611 \\
\hline Provincial Audit & $\ldots$ & $\ldots$ & & 2.269 & 2,368 & 1,585 & 2,603 & 3,132 \\
\hline & & $\cdots$ & $\ldots$ & 296,180 & 264,493 & 257,210 & 294,388 & 384,586 \\
\hline
\end{tabular}

In the first place, the expenditure in connection with the department of inland Revenue shows an almost continuous increase. This is attributable to the extension of the activities of the department on account of increased taxation, which was occasioned by the prevalence of war conditions. Income taxation was introduced in $1914^{36}$ and was considerably extended in subsequent years in accordance with the intensity of the need for additional revenue. In 1917 the Income Tax Consolidation Act ${ }^{3 i}$ was passed, providing for the imposition of four taxes: Normal tax, super tax, Dividend tax and Excess Profits tax. In addition, a duty on the export of diamonds was imposed in $1916^{38}$, and two special war levies of

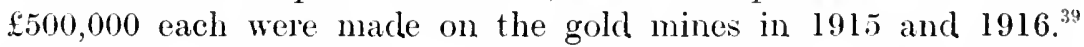
In order to cope with the additional demands on the Internal Revenue department, the permanent staff was increased from $66 ;$ in 1914 to 127 in 1918 ; and, moreover, the latter year witnessed 83 temporary assistants on the pay-roll of the department. ${ }^{40}$ As a result of this the expenditure increased over 130 per cent. between 19]1-12 and 1919-20.

As regards the 'Treasury, the department of Customs and Excise and the department of the Controller and Auditor-General, the expenditures present a decrease at the beginning of the war period in consequence of a policy of retrenchment wherever possible, followed by an increase toward the end of the period in view of

34 Ibid, sec. 92.

35 O.Y.B. 1918, p. 689, and Quarterly Abstract of Union Statistics, Oct. 1920, p. 77.

36 Act 28 of 1914 .
37 Aet 41 of 1917 .

38 Act 36 of 1916 .

39 Acts 24 of 1915 and 34 of 1916 .

40 O.Y.B. 1919 , p. 111 . 
war bonuses to civil servants, an increase which was even accentuated after the cessation of hostilities on aceount of the further enhancement of the cost of living and a general rise in the salaries of public officials. In all three departments coneerned the expenditures for the financial year 1917-18 were still slightly lower than those for 1911-12. Until 1918 the war bonus facilities applied merely to married men in receipt of a salary of less than $£ 360$ per annum, and consequently did not constitute a heavy burden on revenue, especially as the amount of the war bonus was only $£ 30$ per year. Toward the end of 1918, however, the war bonus was extended to unmarried officials as well as to those whose emoluments

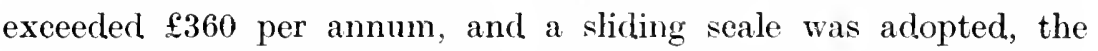
amount of the bonus rising in proportion to the amount of the salary. This new regulation entailed a substantial inerease in expenditures in 1918-19, an increase of about 14 per cent. over those of the preceding year. In 1919 , as a result of the reconmendations of the Public Service Commission of Inquiry which was appointed by the Union Government for the purpose of investigating the claims of the civil servants for higher salaries, a general inerease in salaries was granted, which likewise represented a heavy drain on revenue, causing another inerease of abont 14 per eent. in the expenditures of the rarious sub-departments of the department of Finance.

Taking the Department of Finance as a whole, the period from 1911-12 to 1919-20 registers an increase of about 30 per cent.--from

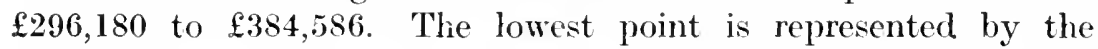
first year of the war, 1914-15, when the expenditure had declined to $£ 253,061$. Regarding the white population as a justifiable basis for a per eapita eomputation in this case, there has been a per capita increase of 13 per eent. as contrasted with a total inerease of 30 per cent. As to the total population, the per capita inerease was merely 11 per cent.

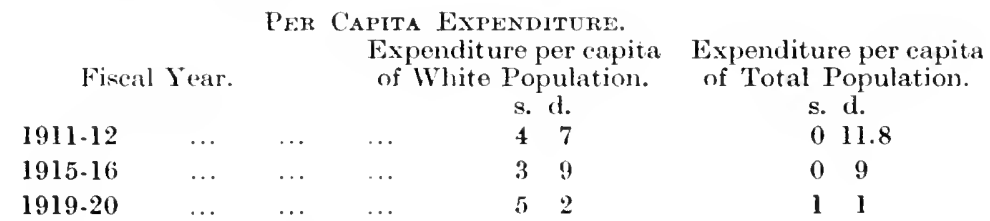

(3) Public Works and Buildings.

The Department of Public Works is charged with the erection, equipment and maintenance of public offices and institutions for the Union and various provineial purposes, the erection of pro- 
vincial and inter-provincial bridges, the provision of accommodation and other services for all departments throughout the Union, and the administration of Government property in mban areas. It is represented in Parliament by the Minister of Public Works and has, as its permanent head, the Secretary for Public Works. As regards technical experts, the departmental staff includes. ten district engincer's, stationed at the important centres, and an electrical engineer. ${ }^{41}$

The relation between the eentral and the provincial governments in respect of this sphere of activity was clearly defined in the Union Constitution. The Provincial Administrations were entrusted with "local public works, with the exception of railroads, ports, harbours and other works which extend beyond the borders of the province, subject to the power of Parliament to declare such works national," and with "roads and bridges, except when initing two provinces". 42 In other words, the jurisdiction of the Provincial Governments was confined to purely local works and provincial roads and bridges, whereas inter-provincial roads and bridges and all institutions of a national character were assigned to the Union Government.

The policy of both the central and the local governments was to make substantial appropriations every year from revenue for the crection of new works, buildings, roads and bridges. The advent of the war, however, obliged the authorities to resort to retrenchment in the matter of public works and buildings, not only with reference to appropriations from revenue but also from loan funds.

The central and provincial expenditures from revenue on public works and buildings are presented in the following table :- ${ }^{43}$

Head of Expenditure.

1911-12. 1913-14. 1915-16. 1917-18. 1919.20.

Administration, Engineering and Architects' Staff ... ...

Rents, Rates, Insurance, Water and Jight $\ldots \quad \ldots \quad \ldots$

Now Works and Buildings ...

Maintenance of Works and

\begin{tabular}{|c|c|c|c|c|c|c|c|}
\hline Buildings & $\ldots$ & $\ldots$ & 201,736 & 200,044 & 135,410 & 146,887 & 176,212 \\
\hline New lioads & $\ldots$ & $\ldots$ & 89,510 & 146,286 & 62,395 & 99,389 & 131,802 \\
\hline Maintenance of & Roads... & $\ldots$ & 268,361 & 328,738 & 272,513 & 308,285 & 448,538 \\
\hline New Bridges & $\ldots$ & .. & 64,118 & 6,689 & 5,806 & 2,080 & 4,165 \\
\hline Maintenance of & Bridges & . & 7,971 & 24,535 & 12,640 & 13,391 & 14,158 \\
\hline Miscellancous & $\ldots$ & $\ldots$ & 833 & 4,296 & 6,856 & 26,882 & 224,818 \\
\hline & 'l'otal & $\ldots$ & $1,656,549$ & $1,518,549$ & $1,007,835$ & $1,029,747$ & $1,574,498$ \\
\hline
\end{tabular}

41 O.Y.B. 1918, P. 105.

42 S.l. Act, sec. 8.5.

\begin{tabular}{rrrrr}
$\mathfrak{f}$ & \multicolumn{1}{c}{$\mathfrak{f}$} & \multicolumn{1}{c}{$\mathfrak{c}$} & \multicolumn{1}{c}{$\mathfrak{c}$} & \multicolumn{1}{c}{$\mathfrak{c}$} \\
196,217 & 232,517 & 179,372 & 197,589 & 295,266 \\
& & & & \\
257,569 & 274,859 & 284,402 & 176,362 & 200,364 \\
570,234 & 282,585 & 48,441 & 58,882 & 79,175 \\
& & & & \\
201,736 & 200,044 & 135,410 & 146,887 & 176,212 \\
89,510 & 146,286 & 62,395 & 99,389 & 131,802 \\
268,361 & 328,738 & 272,513 & 308,285 & 448,538 \\
64,118 & 6,689 & 5,806 & 2,080 & 4,165 \\
7,971 & 24,535 & 12,640 & 13,391 & 14,158 \\
833 & 4,296 & 6,856 & 26,882 & 224,818 \\
\hline 656,549 & $1,518,549$ & $1,007,835$ & $1,029,747$ & $1,574,498$ \\
\hline
\end{tabular}

43 O.Y.B. 1918, pp. 696 and 709, and O.Y.B. 1920 . 
Most of the items of expenditure in the aforegoing table were subject to reduction in the first few years of the war. The most notable decreases are eneountered in the ease of the construetion of new works, buildings and roads, in respeet of which the expenditure declined from $£ 453,560$ in $1913-14$ to $£ 271,244$ in 1914-15 and $£ 110,836$ in $1915-16$, as well as in that of the maintenance of works, buildings and roads, the expenditure on which declined from $£ 528,782$ in $1913-14$ to $£ 384,590$ in $1914-15$ and $£ 407,923$ in 1915-16. In the matter of inter-provincial roads and bridges the expenditure was virtually negligible after 1914. The total expenditure from revenue showed a deerease of over 30 per cent. in 1915-16 as eompared with the expenditure in 1913-14, which represents quite a substantial retrenehment. Toward the end of the decade the expenditure was enhanced by the increased cost of living and of materials, but in spite of the depreciation in the purchasing power of money the expenditure for 1919-20 was practically on a par with that of 1913-14.

The capital outlay, on the other hand, was not subject to any considerable reduction at the beginning of the war, as revealed in the following table :-

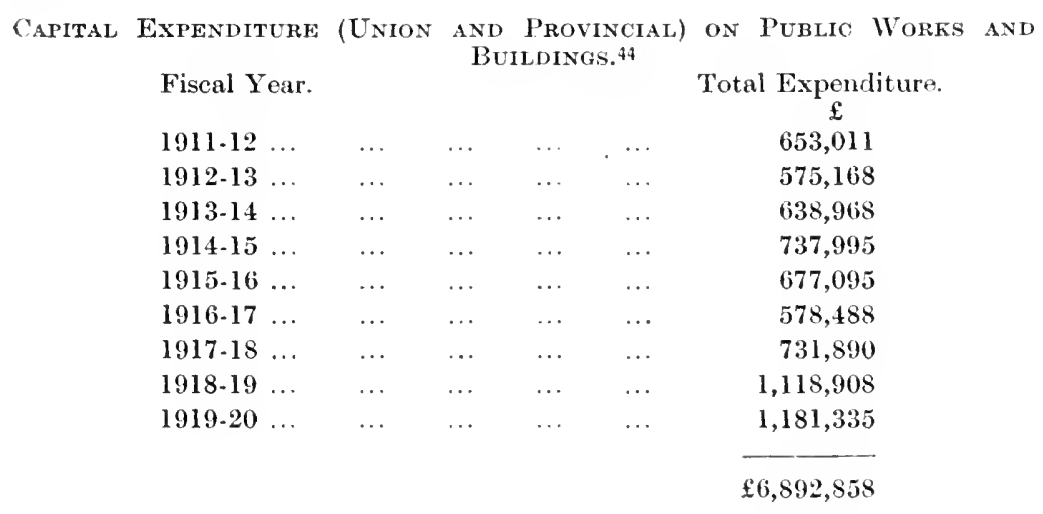

The expenditure from revenue on the construction of new works, buildings, roads and bridges represented a considerable sum, amounting in 1911-12 to $£ 723,862$ and in 1912-13 to $£ 1,078,726$. The prevalenee of war conditions and the need for retrenchment brought it down to $£ 116,642$ in $1915-16$, a very striking contrast to the expenditure of 1912-13.

As regards the construetion of roads the Orange Free State is the only provinee that has incurred capital expenditure in respeet

44 O.Y.B. 1918, p. 716, and O.Y.B. 1920.

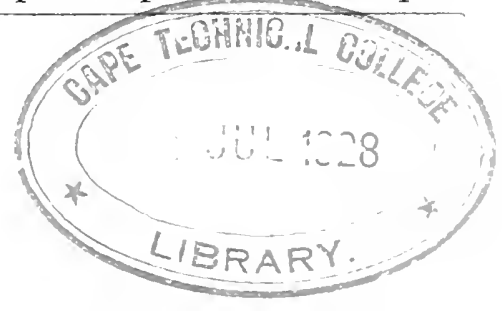


thereof, and that is comparatively insignificant, amounting merely to $£ 139,561^{45}$ from April 1, 1913, to March 31, 1918. This is to be accounted for by the provisions of the Financial Relations Act of 1913 for loans to the provinces by the Treasury in respect of capital or non-recurrent expenditure, such expenditure being defined as " expenditure upon the erection, construction, acquisition, extension or improvement of any building, bridge, pont, or upon any work or undertaking of a permanent nature in relation to a matter entrusted to the province, but not expenditure upon the construction of a road, unless authorised by the Treasury in special cases." ${ }^{46}$ This restriction has proved to be effective, the Orange Free State being the only province which, during the period under consideration, had occasion to resort to capital expenditure in regard to the construction of roads; and during the five-year period from April 1, 1913, to March 31, 1918, such expenditure constituted more than one-third of the total capital expenditure of that province, namely, $£ 139,561$ out of $£ 392,325 .{ }^{47}$

The Financial Relations Act contains further provisions in respect of the capital expenditure of the provinces, namely, that if the expenditure upon any building or extension thereof does not exceed $£ 500$, or if the expenditure upon any bridge, pont or other such work or undertaking does not exceed $£ 1,500$ such expenditure is deemed to be normal or recurrent expenditure, except by provision of the Executive Committee of a province with the approval of the Union Treasury. ${ }^{4 i}$

The per capita expenditure from revenue on public works and buildings, with regard to the white population, declined from £1 5s. 10d. in 1911-12 to $£ 1$ 1s. 3d. in 1919-20, a decrease of 18 per cent. as compared with an absolute decrease of 5 per cent.

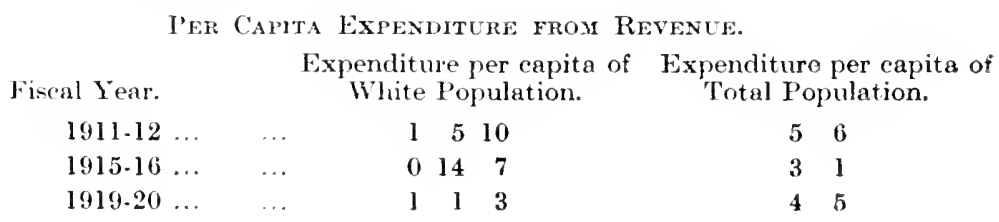

45 O.Y.B. 1919, p. $\$ 75$.

46 Act 10 of 1913 , sec. i.

47 O.Y.B. 1919 , p. 875. 


\section{CHAPTER 2.}

\section{National Defence.-Justice.}

\section{(1) National Defence.}

The military expenditures of the Union, during the decade under consideration, permit of sub-division into two distinet categories: (a) the expenditure in respect of the ordinary peace establishment, covering the period from the inception of the Union (Nay 31, 1910) to the declaration of war by Great Britain (August 4, 1914), and (b) the war expenditures, which extend into 1920.

The naval expenditures, on the other hand, consist merely of an annual contribution of $\$ 85,000$ to the British Navy.

The military and naval expenditures fall within the jurisdiction of the Union Department of Defence, which is represented in Parliament by the Minister of Defence. The Secretary for Defence is the permanent head of the department. The defence system of the Union was instituted by the Defence Aet ${ }^{1}$ of 1912, which stipulates that every eitizen of European descent is liable, between his seventeenth and his sixtieth year, to render in time of war personal service in defence of the country in any part of South Africa within or without the Union ${ }^{2}$; and, further, that every eitizen of sound physique between the ages of seventeen and twentyfive is liable to undergo a eourse of peace training for four years. ${ }^{3}$

Prior to the inauguration of this system, the defence establishment of the Union was composed merely of the District Headquarters Staffs and the Cape Mounted Riflemen, comprising a joint foree of about 1,000 men and representing the permanent and professional element, and the Militia and Volunteer Corps which was taken over from the four Colonies by the Union. ${ }^{4}$

The administration of the Union Defence Force is vested in a Council of Defence, a headquarter staff, and instructional and administrative staffs for the fiftcen military districts of the Union. ${ }^{5}$ The Union Defence Force is of the nature of a militia and is constituted as follows: (1) the Permanent Force, consisting of five regiments of South Afriean Mounted Riflemen equipped with batteries of artillery, and forming the first line of defence, and acting in

1 Act 13 of 1912 .

2 Ibid. sec. 1.

3 Ibid, sec. 2.
4 Worsfold : Union of S.A., p. 444.

5 Act 13 of 1912. secs. 29 and 30. 
time of peace as a police force throughout large portions of the Union $^{6}$; (2) the Coast Garrison Force, consisting of the South African Garrison Artillery and the Coast Defence Corps, the members of which are voluntarily enrolled and are paid for the attendance of drills ${ }^{7}$; (3) the Citizen Force, composed of all persons liable to render personal service in time of war (other than members of the forces mentioned) and comprising three divisions, the Active Citizen Force, the Citizen Force Reserve, and the National Reserve. ${ }^{8}$ The Active Citizen Force consists of men who are undergoing peace training for four years between the ages of seventeen and twentytive. ${ }^{9}$ The Citizen Force Reserve is divided into two classes, A and $\mathrm{B}$, class $\mathrm{A}$ being composed of men who have undergone peace training and are not over 45 years of age, and class B of men who are serving or have served in Rifle Assoniations and who are not over 45 years of age." 'The National Reserve embraces all citizens between the ages of 17 and 60 years who are not serving in any other portion of the Defence Force. ${ }^{11}$

The expenditures in respect of the peace establishment of the Union were as follows: ${ }^{12}$

\begin{tabular}{|c|c|c|c|}
\hline & Expendituro & Expenditure per & Expenditure per \\
\hline Period. & $\begin{array}{c}\text { Establishment } \\
\mathfrak{f}\end{array}$ & $\begin{array}{l}\text { Population. } \\
\text { s. d. }\end{array}$ & Population. \\
\hline
\end{tabular}

May 31,1910 , to Mar.

\begin{tabular}{|c|c|c|c|c|}
\hline 31,1911 & $\ldots$ & 361,151 & - & - \\
\hline 1911.12 & & 456,707 & $\begin{array}{ll}7 & 2\end{array}$ & 1 \\
\hline 1912.13 & $\ldots$ & 787,365 & 120 & 2 \\
\hline 1913.14 & $\ldots$ & $1,279,567$ & 193 & 4 \\
\hline April 1, 1914 & ug. & 451830 & 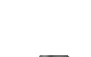 & - \\
\hline
\end{tabular}

The financial year 1912-13 shows a considerable increase in expenditure over that of the preceding year due to the coming into effect of the Defence Act of 1912, and in 1913-14 there was a further increase as a result of the expansion of the activitics of the Defence Department. The Defence Force system occasioned an increase of almost 200 per cent. in the normal military expenditures in 1913-14 as compared with those in 1911-12.

Upon the declaration of war the defenee organization was placed on a war basis. The requirements of registration and training in respect of all eitizens between the ages of 17 and 25 were tem-

\footnotetext{
6 Ibid, secs. 11 and 12 .

7 Ibid, sec. 13.

8 J bid, sec. 16.

9 Ibid, sec. 17.

10 Ibid, sec. 20.

11 Ibid. sec. 21 .

12 S.Y.13. 1914-15, p. 230.
} 
porarily suspended, and certain divisions of the organized Defence Force were called out on duty in order to release the Imperial troops from service abroad. In September, 1914, a special session of Parliament was convened, and it was resolved to undertake the conquest of German South-West Africa. As a result of this resolution of Parliament General Beyers, the Commander-in-Chief of the Union, tendered his resignation in protest against the projected military policy of the Government. This course of action served to stimulate certain sections of the population in the Orange Free State and in the Transvaal (the former Boer Republics) to organize an armed protest, as the military authorities had initiated a policy of commandeering the farmers for active service in German SouthWest Africa in view of the physical difficulties which were likely to be encountered in such a sparsely-populated and desert-like territory, and of the superior ability of the rural inhabitants to endure the probable hardships. The armed protest developed into a rebellion, and civil war raged for two months, the rebellion being virtually suppressed in December, 1914.

Immediately after the conchusion of domestic hostilities, the German South-IVest African campaign was undertaken in earnest and was financerl entirely by the Union Government. The eonquest was completed by the beginning of July, 1915, when the German troops surrendered. The territory was proclaimed a military protectorate, and the administration and garrisoning thereof was undertaken by the Union Government:

Toward the end of 1915 the Union Government proposed to raise voluntary contingents for service in Europe, called "Imperial Service Contingents." These contingents were to be maintained by the British Government, and the Union Government offered to contribute towards the eost of maintenance. In the beginning of 1916 General Smuts was placed in supreme command of the British troops engaged in the campaign against German East Africa. The Union Government assumed the task of securing recruits for the purpose of reinforcing the army operating in that region, as such was wholly insufficient. The cost was to be borne by the Imperial Treasury, but the Union Government proposed to pay the difference between the Imperial rates of pay and allowances for Union contingents in Central and East Africa and those prevailing in the Union Active Citizen Force.

In addition, expenditures were incurred in connection with the internment camps at Pietermaritzburg and in respect of compensation for rebellion losses. 
The war expenditures of the Union may aecordingly be classified under five heads: (1) direct war expenditure; (2) expenditure with regard to the administration and garrisoning of the South-West Afriea Military Protectorate; (3) military pensions; (4) cost of maintenance of internment camps; and (5) compensation for rebellion losses.

The direct war expenditure includes all expenditures incurred in connection with the South African rebellion, the German SouthWest Afriean campaign, the contributions of the Union Government towards the cost of Imperial Service Contingents raised in the Union. and the appropriations for the additional remuneration of Union forees engaged in Imperial military service in Central and East Africa. These expenditures eonstitute the overwhelming proportion of general war expenditures and were estimated to amount to $£ 35,694,000^{13}$ on the 31st March, 1920 .

As regards the administration and garrisoning of the South-West Africa Military Protectorate, the total expenditure (after deducting revenue) was estimated to comprise $\mathfrak{f 2}, 205,950^{14}$ by Mareh 31 , 1920. An analysis of the expenditure in this connection during the financial year 1916-17 will serve to inclieate the range of governmental activities in that territory :- ${ }^{15}$

Service.

(a) Administration

(b) Garrison

(c) Public Works and Irrigation

(d) Posts, 'Telegraphs and Telephones

(e) Miscellaneous
Expenditure.

$\mathfrak{f}$
21,843
596,982
41,271
23,852
60,444

$\mathfrak{f 7 4} 4,392$

Total

- Military Pensions.-Prior to the recent European war military pensions represented an insignifieant item of expenditure, the number of persons in receipt of pensions in respect of former wars being relatively small. Even the first few years of the war did not appreciably affect the amount of such expenditure. It was not until 1918 that military pensions commenced to assume important dimensions, the years 1919 and 1920 witnessing further aceentuations of this problem.

In 1916 the first War Special Pensions Aet $^{16}$ was passed, with a view to making special provision for the payment of pensionable

\footnotetext{
13. Half-yearly Abstract of Union 15 Appropriation Acconnts, 1916-17. Statisties, lime 1019, p. 89.

14 Ibid.

15 Appropriation Acco $n 1$ ts, $1916 \cdot 17$.
16 Act 29 of 1916.
} 
benefits or awards to persons who had sustained wounds or injury or who had contracted diseise or suffered permanent ill-health while on active service in any of His Majesty's Forees, and to the dependents of persons who had been killed or who had died from wounds or injury received or disease or illness contracted while on active service. Further Acts were passed in 1917, 1918 and 1919, the War Special Pensions Aet of $1919^{17}$ being the most important legislative enactment in regard to military pensions.

The provisions of this Act are sub-divided under five headings: (1) Compensation for disablement, the pension being based either on the degree of general physical disablement or on the loss of earning eapacity ${ }^{18} ;(2)$ compensation in respect of deceased soldiers, the widow of a deceased soldier receiving a pension, together with an allowance in respect of each child maintained by her ${ }^{19}$; compensation in respect of Government servants, who receive the civil pension in addition to the military pension: ${ }^{29}(4)$ compensation to disabled nurses; (5) compensation in respect of military service in previous South African wars.

The following table elearly illustrates the movement of the expenditure in regard to military pensions and gratuities, showing the varying effects of the four legislative measures according to the intensity of the pecumiary provisions and the scope of their application.

\begin{tabular}{|c|c|c|c|}
\hline scal Year. & $\begin{array}{c}\text { Expenditure on } \\
\text { Military Pensions. }{ }^{21}\end{array}$ & $\begin{array}{l}\text { Expenditure per } \\
\text { capita of White } \\
\text { Population. }\end{array}$ & $\begin{array}{l}\text { Expenditure per } \\
\text { capita of Total } \\
\text { Population. }\end{array}$ \\
\hline
\end{tabular}

$\begin{array}{cccccccc} & & & \mathfrak{L} & \text { s. } & \text { d. } & \text { s. } \\ 1911-12 & \ldots & \ldots & 34,123 & 0 & 6 \frac{1}{2} & 0 & 1 \frac{1}{2} \\ 1913-14 & \ldots & \ldots & 29,199 & 0 & 5 & 0 & 1 \\ 1915-16 & \ldots & \ldots & 44,300 & 0 & 7 \frac{1}{2} & 0 & 1 \frac{1}{2} \\ 1917-18 & \ldots & \ldots & 107,906 & 1 & 6 & 0 & 3.8 \\ 1918-19 & \ldots & \ldots & 290,444 & 4 & 0 & 0 & 10 \\ 1919-20 & \ldots & \ldots & 755,535 & 10 & 0 & 2 & 1\end{array}$

The War Special Pensions Acts of 1916 and 1917 occasioned large relative increases in expenditure, but it was left to the Acts of 1918 and 1919 to register substantial absolute increases.

In respect of the internment camps, an official estimate presents the total expenditure to have been $£ 817,171^{22}$ on March 31,1920 .

\begin{tabular}{|c|c|}
\hline $\begin{array}{l}\text { 'Act } 42 \text { of } 1919 . \\
18 \mathrm{Ibid} \text {, sec. } 2 . \\
19 \mathrm{Ibid} \text {, sec. } 16 \text { (1). } \\
20 \mathrm{Ibid} \text {, sec. } 29 .\end{array}$ & $\begin{array}{l}21 \text { O.Y.B. 1918, p. } 691 \text {, and Appro- } \\
\text { priation Accounts, 1919-20. } \\
22 \text { Half-ycarly Abstract of Union } \\
\text { Statisties, June } 1919, p .80 \text {, and Appro. } \\
\text { priation Accounts, } 1919-20 \text {. }\end{array}$ \\
\hline
\end{tabular}


The compensation for rebcllion losses represented an expenditure of $£ 72,391 . .^{22}$

The war expenditures of the Union were defrayed mainly from loan funcls, the annual appropriations from revenue being the mere equivalent of the normal expenditure for defence purposes, plus the expenditure on military pensions. The total war expenditures may be represented in tabular form as follows :- ${ }^{22}$

\begin{tabular}{|c|c|c|c|c|c|}
\hline \multicolumn{3}{|c|}{$\begin{array}{l}\text { Fiscal Period. } \\
\text { Aug. 4, 1914-Mar. } 31\end{array}$} & \multirow{2}{*}{$\begin{array}{c}\text { From } \\
\text { Revenue Funds. } \\
\stackrel{f}{ } \\
939,461\end{array}$} & \multirow{2}{*}{$\begin{array}{c}\text { From } \\
\text { Loan Funds. } \\
£ \\
9,258,959\end{array}$} & \multirow{2}{*}{$\begin{array}{c}\text { Total. } \\
\mathfrak{E} \\
10,198,420\end{array}$} \\
\hline 1915 & $\ldots$ & $\ldots$ & & & \\
\hline $1915 \cdot 16$ & $\ldots$ & $\ldots$ & $1,044,300$ & $10,707,138$ & $11,751,438$ \\
\hline 1916-17 & $\ldots$ & $\ldots$ & $1,347,658$ & $2,670,058$ & $4,017,716$ \\
\hline 1917.18 & $\ldots$ & $\ldots$ & $1,407,906$ & $3,452,156$ & $4,860,062$ \\
\hline $1918-19$ & $\ldots$ & $\ldots$ & $1,590,444$ & $3,213,785$ & $4,804,229$ \\
\hline 1919.20 & $\ldots$ & $\ldots$ & $2,276,065$ & $2,072,626$ & $4,346,691$ \\
\hline & & $\ldots$ & $8,605,834$ & $31,374,722$ & $39,980,556$ \\
\hline
\end{tabular}

The foregoing table indicates that the bulk of the war expenditure (56 per cent.) had been met by March, 1916. The major portion of this expenditure was incurred in connection with the campaign in German South-West Africa, which was successfully terminated in July, 1915. The result was that at a comparatively early stage of the war period the war expenditures had occasioned an addition of about $£ 1,000,000$ to the annual interest charge, which again represented an increase of about 6 per cent. in the ordinary expenditures of the Union Government (excluding railways and harbours) for the year 1916-17. By Narch, 1920, the war expenditures from loan funds had involved an annual interest charge of about $£ 1,432,219$, which is practically the same as the appropriation for defence from revenue funds in 1919-20, namely, $£ 1,520,530$.

The interest on the debt contracted on account of the war operations, constituting a charge against revenue, may justifiably be included in a computation of the war expenditures defrayed from revenue, and would accordingly increase the percentage of war expenditures met from that source. However, taking into consideration merely the specific appropriations from revenue for war purposes, it will be found that 21 per cent. of the total war expenditure was defrayed from revenue funds.

The per capita expenditure in respect of the war operations in which the Union was involved (taking the total expenditure as

22 Half-yearly Abstract of Union Statisties, June 1919, p. 80, and appropriation Accounts, 1919-20. 
on March 31,1920 ) is $\mathfrak{f 2 7}$ for the white population and $\mathfrak{f 5} 12 \mathrm{~s}$. for the total population.

(2) Justice.

A. Departmental Administration.-On the establishment of the Union a Ministry of Justice was created in substitution for the practice previously in force in each of the Colonies, under which the Attorney-General had been a nember of the Ministry and had assumed ministerial responsibility for the Law Department of the Colony. In accordance with the provisions of the South Africa Act $^{23}$ the administration of justice throughout the Union was placed under the control of the Minister of Justice. An exception was, however, made in regard to powers, authorities and functions relating to the prosecution of crimes and offences, which were vested in an attorney-general for each province. These attorneysgeneral are members of the public service of the Union and are appointed by the Union Government.

The expenditure in respect of departmental administration includes that relating to the conduct of government litigation, the drafting of government bills and publication of statutes and statutory regulations, and the granting of legal advice to Government departments.

Expenditure on Departmental Admistration.24

$\begin{array}{cccc}\text { Total } & \begin{array}{c}\text { Expenditure per } \\ \text { capita of White } \\ \text { Population. }\end{array} & \begin{array}{c}\text { Expenditure per } \\ \text { capita of Total } \\ \text { Population. }\end{array}\end{array}$

$\begin{array}{ccccccc} & & & \mathcal{E} & \text { s. } \text { d. } & \text { d. } \\ 1911-12 & \ldots & \ldots & 60,263 & 0 & 11.3 & 2.4 \\ 1913-14 & \ldots & \ldots & 68,146 & 1 & 0 & 2.6 \\ 1915-16 & \ldots & \ldots & 69,108 & 1 & 0 & 2.5 \\ 1917-18 & \ldots & \ldots & 66,660 & 0 & 11.2 & 2.3 \\ 1919-20 & \ldots & \ldots & 69,896 & 011.3 & 2.3\end{array}$

This item of expenditure has been comparatively stationary, the variations from year to year having been very slight, especially after 1913-14.

B. Superior Courts.-Prior to the inauguration of the Union, the administration of justice in each Colony was entrusted to a Supreme Court, the powers and authorities whereof were defined by statute. Within the limits of the Colony, each Supreme Court had full jurisdiction, subject to appeal in the last resort to the Judicial Committee of the Privy Council in England. 
The Sonth Afriea Act created one Supreme Court for the whole Inion, consisting of the Chief Justice of South Africa, the ordinary julges of appeal, and the other judges of the various divisions of the Supreme Court of South Africa in the Provinces. An Appeal ('ourt was also instituted, known as the Appellate Division of the supreme ('ourt of South Africa, eomposed of the Chicf Justice, the two ordinary judges of appeal, and two additional judges of appeal who are assigned to the Appellate Division by the Union Government from the provincial divisions of the Supreme Court. ${ }^{25}$

At the establishment of the Union the respective Supreme Courts of the eomstituent Colonies became Provincial Divisions of the Supreme Court of South Africa, each for its Province, the presiding judge in each such division being styled the Judge-President.

Each Province is divided into circuit districts, and Circuit Courts are held by a judge twice a year in each district.

Thus the system of administration of justice in Superior Courts in South Africa comprises the following judicial institutions :-

(1) Court of Appeal ;

(2) Provincial Divisions of the Supreme Court at Cape Town, Pretoria, Pietermaritzburg and Bloemfontein, and Local Divisions in the three chief industrial centres, the Rand, Kimberley, and the Eastern Districts of the Cape Province ;

(3) Circuit Courts held by the Provincial Divisions in the smaller towns of the four Provinces.

Expenditure on Superior Courts. 26

\begin{tabular}{|c|c|c|c|c|}
\hline Fiscal lear. & & $\begin{array}{c}\text { Total } \\
\text { Expenditure. } \\
\mathfrak{f}\end{array}$ & $\begin{array}{l}\text { Expenditure per } \\
\text { capita of White } \\
\text { Population. } \\
\text { s. d. }\end{array}$ & $\begin{array}{l}\text { Expenditure per } \\
\text { capita of Total } \\
\text { Population. } \\
\text { d. }\end{array}$ \\
\hline$\ldots$ & $\ldots$ & 203,739 & 3 & 8 \\
\hline$\ldots$ & $\ldots$ & 199,539 & 30 & 7.6 \\
\hline$\ldots$ & $\ldots$ & 180,736 & 27 & 6.6 \\
\hline$\cdots$ & $\cdots$ & 179,788 & 26 & 6.3 \\
\hline$\ldots$ & $\ldots$ & 209,046 & 210 & 7 \\
\hline
\end{tabular}

The expenditure on Superior Courts has also been fairly stationary, the difference between the disbursements in 1911-12 and 1919-20 being insignificant. The policy of economy induced by the war was applicd with success in respect of this item of expenditure, the amount in 1917-18 being less than that in 1913-14 by about 10 per cent. The rise in the cost of living, however, necessitated 
an increase in emoluments, with the result that the expenditure in 1919-20 surpassed the pre-war level by a small margin.

C. Magistrates' Courts and Offices.-These are the lower eourts which have jurisdietion in the magisterial district for which they are created. Prior to January 1, 1918. the jurisdiction of magistrates' courts was determined by the provisions of a considerable number of statutes passed by the respective legislatures of the Colonies now comprised in the Union. Subsequent to that date it had been governed by a consolidating and amending Act (Magistrates' Courts Aet). ${ }^{27}$

In addition to his judicial functions, the magistrate acts as the local representative and agent of the Union Government, dealing with such matters as the preparation of the voters' lists, the keeping of the civil register, supervision of tax collection. of the military organization in his slistrict, ete. In short, the magistrate's office is a composite ageney undertaking all the local functions of the various govermmental departments.

Expenditure on Magistrates' Courts and Offices. ${ }^{2 *}$

\begin{tabular}{|c|c|c|c|c|}
\hline Fiscal Year. & & $\begin{array}{c}\text { Total } \\
\text { Expenditure. } \\
\mathfrak{f}\end{array}$ & $\begin{array}{l}\text { Expenditure per } \\
\text { capita of White } \\
\text { Population. } \\
\text { s. d. }\end{array}$ & $\begin{array}{l}\text { Expenditure per } \\
\text { capita of Total } \\
\text { Population. } \\
\text { s. d. }\end{array}$ \\
\hline$\ldots$ & $\ldots$ & 427,818 & 68 & 15 \\
\hline$\ldots$ & $\ldots$ & 440,675 & (i) $7 \frac{1}{2}$ & 14.9 \\
\hline$\ldots$ & $\ldots$ & 428,013 & (i) $2 \frac{1}{2}$ & 13.7 \\
\hline$\ldots$ & $\ldots$ & 433,139 & $\begin{array}{ll}6 & 0.7\end{array}$ & 13.2 \\
\hline$\ldots$ & $\ldots$ & 500,243 & $\begin{array}{ll}6 & 9\end{array}$ & 15 \\
\hline
\end{tabular}

In respect of this branch of expenditure the principle of economy was capable of execution. During the first three years of the war the expenditure was kept below the level of 1913-14, but the introduction of the general war bonus in 1918 and the rise in salaries and wages in 1919 occasioned a substantial increase during the last two years of the decade. However, during the period from 1911-12 to 1919-20 the expenditure on magistrates' courts and offices was enhanced merely by 17 per cent.

D. Police.-A Chief Commissioner was appointed for the Union, with administrative headquarters at Pretoria. The various systems and methods prevailing prior to the Union were consolidated and unified, and the police forees of the Colonies reorganized as the South African Police. On the 31st of May, 1910, 
the police forces of the Colonies comprised 10,169 (6,232 Europeans and 3,937 natives, coloured and Indians), whereas on March 31, 1919 , these had declined to $7,505 .^{29}$

This decrease is to be ascribed to three factors: (1) retrenchment consequent upon the establishment of the Union and the consolidation of the four Colonial forces; (2) the Defence Act ${ }^{30}$ of 1912 provicled for a permanent force, consisting of five regiments of Sonth African Mounted Riflemen, which in time of peace acts as a police force throughout large portions of the Union ${ }^{31}$; (3) after the outbreak of the war a large number of police officers enlisted from time to time and the vaeancies could not all be filled, the number of resignations exceeding the number of approved applications.

Expenditure on Police. 32

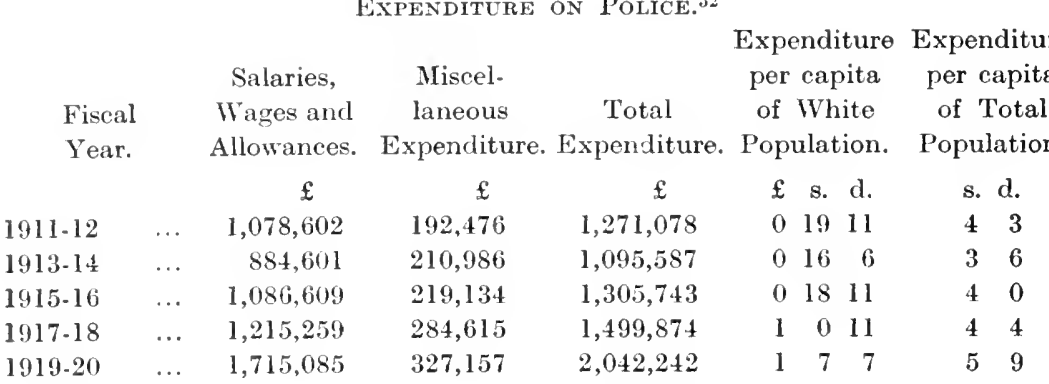

The diminution of the police foree oceasioned by the reorganization of the Colonial forces and the creation of a permanent military force under the Minister of Defence explains the decline in the expenditure on police from $£ 1,271,078$ in $1911-12$ to $£ 1,095,587$ in 1913-14. Subsequent to that year there was a steady increase, as the result of, first, the policy of regarding police officers on active service as being on leave of absence and granting them half-pay in addition to paying their substitutes; secondly, the introduction of the war bonus; and finally, the inerease in salaries and wages. In consequence of the operation of these factors the expenditure on police was subject to an inerease of 60 per cent. during the period under review.

E. Prisons and Reformatories.-The administration of the prisons of the Union is placed under the Direetor of Prisons in the Departmont of Justice. The guiding principles of the Union penal system

29 O.Y.B. 1919 , p. 412.

3c Act 13 of 1912 .

31 O.Y.B. 1918, p. 355.
32 O.Y.B. 1918, p. 693, O.Y.B. 1919 , p. 850 , and Appropriation Accounts 1919.20 . 
are to rescue the child from criminal environment and prevent it from becoming a criminal; to build up and supplement in the criminal the elements necessary to prevent a recurrence of crime, and, if all else fails, by means of the indeterminate sentence to remove the habitual criminal from society and prevent his remaining a menace to it; but even then to allow him an opportunity of self-redemption. It seeks to attain these objects through the instrumentality of government industrial schools for waif and stray children, of reformatories for children who have committed crime, and of various penal institutions for adults. (The factor's operating in the prison for the purpose of reformation are religious and moral influences, schooling, drill and discipline, the training of the hand and the eye, and sound literature.)

With a view to minimizing the dangers of a sudden release the prison farm has been introduced. where the prisoner gradually accommodates himself to the conditions of outside life. As regards the native, the road camp has been created, so that for venial offences against the pass law. the tax law, or the masters and servants law, he goes direct from court to camp and never actually enters a gaol. ${ }^{33}$ In 1918 there were 9 convict prisons, 185 gaols, 7 reformatories, 3 road camps, 2 farm colonies and inebriate reformatories, 8 labour outstations, and 2 prison farms. ${ }^{34}$

There has been a steady increase in the expenditure on prisons and reformatories as shown in the following table: $-{ }^{35}$

Service.

\begin{tabular}{|c|c|c|c|c|c|c|c|}
\hline \multirow{2}{*}{$\begin{array}{l}\text { Administration ... } \\
\text { Prisons and Gaols : }\end{array}$} & \multirow[t]{2}{*}{$\cdots$} & $\ldots$ & $\begin{array}{l}\mathfrak{f} \\
12,354\end{array}$ & $\begin{array}{l}f \\
14,158\end{array}$ & $\begin{array}{l}\mathfrak{f} \\
15,549\end{array}$ & $\begin{array}{l}\mathfrak{E} \\
14,212\end{array}$ & \multirow[t]{2}{*}{$\begin{array}{l}\mathfrak{f} \\
18,492\end{array}$} \\
\hline & & & & & & & \\
\hline Staff $\quad \ldots$ & $\ldots$ & $\ldots$ & 289,769 & 297,331 & 305,462 & 328,595 & 470,930 \\
\hline Inmates & $\ldots$ & $\ldots$ & 134,703 & 150,939 & 138,672 & 147,523 & 172,678 \\
\hline Reformatories ... & $\ldots$ & $\cdots$ & 14,114 & 27,078 & 28,495 & 36,983 & 48,000 \\
\hline Industrial Schools & $\ldots$ & $\ldots$ & 6,370 & 12,255 & 18,710 & 28,639 & 61,227 \\
\hline & & $\cdots$ & 457,310 & 501,761 & 506,888 & 555,952 & 771,327 \\
\hline
\end{tabular}

The increase of 70 per cent. in the expenditures on prisons and reformatories, during the period under review, is attributable to the war bonus, rise in salaries and wages, increase in the number

3 O.Y.B. 1918 , p. 348.

24 O.Y.B. 1918, p. 348.
35 O.Y.B. 1918, p. 691 and O.Y.B. 1919, p. 848 and O.Y.B. 1920. 
of penal establishments and industrial schools, and the improvement of housing accommodation. This increase was continuous but was held in check up to the third year of the war.

Per Capita Expenditure.

Fiscal Year.

Expenditure per capita of White Population.

Expenditure per capita of s. d. Total Population.

1911.12

$1915 \cdot 16$

$7 \quad 2$

1919.20

74

$10 \quad 5$

8. d.

16

161

$2 \quad 2$ 


\section{CHAPTER 3.}

Education, Agriculture, Promotion and Regulation of INDUSTRY.

(1) Education.

A. Primary and Secondary Education.-In accordance with the provisions of the South Africa Act, ${ }^{1}$ for a period of five years (191015) and thereafter until otherwise determined by Parliament, primary and secondary education was placed under the control of the Provincial Administrations. No legislation has been introduced to alter this administrative arrangement, and as a result each Province has continued to follow its own system and to shape its development according to its own separate policy. Thus four systems of state or state-aided education prevail, which though akin in some respects are entirely dissimilar in others.

Subject to final control of the Provincial Administration, the central direction of public education in each province is exercised by the Provincial Education Department, the permanent head of which in the Cape of Good Hope is the Superintendent-General of Education, in Natal the Superintendent, in the Transvaal and the Orange Free State the Director. ${ }^{2}$

In the Cape of Good Hope, the Transvaal, and the Orange Free State, local school administration is conducted by school boards and school committees. the unit of administration being the school district. In the latter two provinces, however, the school board is mainly an advisory body with general powers of supervision over all public schools in its district, and under its control school committees exercise supervision over the individual schools. In the Cape of Good Hope, on the other hand, the school board has the power, subject to the department, to establish and maintain schools. and is entrusted with the general financial control of schools under its jurisdiction, including the fixing of scales of fees and the hire of buildings. Every public school under a board is ordinarily managed by a committee elected by the parents. Natal has no system of local administration in respect of Government schools. but advisory school committees have been established in some localities to promote local interest. ${ }^{3}$

In 1918 there were 7,723 state and state-aided schools in the Union, of which 4,846 served the white population and 2,877 the 
coloured. 'The total number of scholars was 503,253, namely, 283,149 white and 220,104 coloured. ${ }^{4}$

Taking the white population as the only appropriate basis of calculation, it will appear that the relation between the number of scholars and the population in 1918 in the Cape of Good Hope was practically identical with that in the Transvaal (19.7 and 19.8 respectively), in spite of the fact that in the former province school fees pay on an average one-fourth of the total expenditure on school education, whereas free education prevails in the latter.

The central expenditure on school ciucation is defrayed from grants made by Provincial Councils supplemented by local sources of revenue, if any. In the Cape of Good Hope grants-in-aid of the salaries of teachers and in aid of the purehase of equipment and hire of buildings in the case of all classes of schools are made from the central funds. Contributions from local sources are derived almost entircly from school fees, and until 1917 (in the case of schools under boards) also from a local rate of $\frac{1}{8} \mathrm{~d}$. in the pound on the capital value of rateable property, levied by the local authority to make up any deficiency in the accounts of school boards. 'This local educational rate has been abolished. In the ease of schools controlled by school boards (i.e. the large majority of European schools) the proportion of revenue derived from the Government in 1916 was 68.6 per eent,. from the local rate 5.8 per cent., from fees 25 per cent., and from other sources .6 per cent. In Natal and the Orange Free State the entire cost is defrayed from the central fund, receipts from school fees being paid into that fund. In the Transvaal school education is free, the whole cost being met from the provincial revenue. ${ }^{5}$

The provincial expenditures in respect of primary and secondary education present a striking illustration of increasing public expenditures, as indieated in the following table. ${ }^{6}$

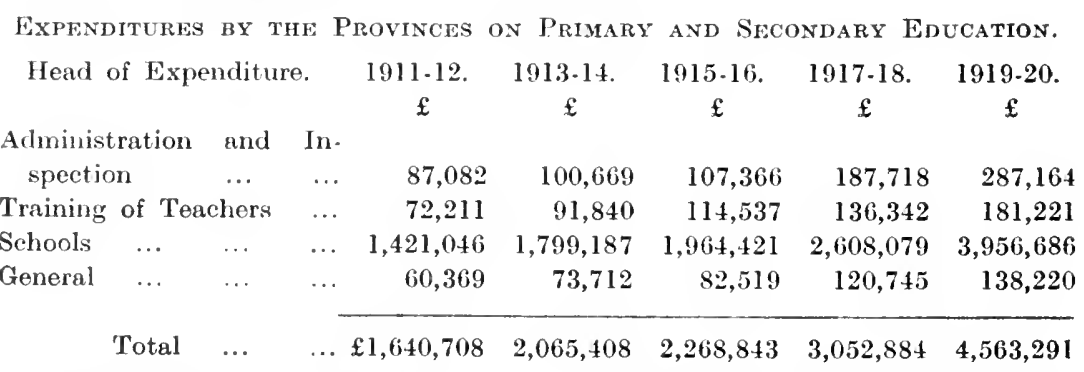

4 Xbid, p. 288.

5 O.Y.B. 1918, p. 261.

${ }^{6}$ O.Y.B. 1918 , p. $706 \&$ O.Y.B. 1920 
During the eight-year period under review the provincial expenditures on education were enhanced by 178 per cent., the causes. of this spectacular increase being two-fold:--

(a) the extension of the educational activities of the provinces, as evideneed by the increase in the number of state and stateaided schools in the Union from 5,872 in 1910 to 7,723 in 1918, of scholars from 299,257 to 503,253 , and of teachers from 10,912 to 18,301 respectively $;^{\top}$

(b) increase in salaries due to increased cost of living, the depreciation in the purchasing power of money affecting also the general expenditures.

Expenditure on edueation eonstitutes by far the most important itcm of ordinary provineial expenditure, and in view of the extraordinary advance in educational expenditures, the proportion has tended to increase, as will appear from the following table.

Fiscal Year.

$1911 \cdot 12$

1915-16

$1919-20$
Percentage of Total

Provincial Expenditure Ordinary Expenditure on Education. of Provinces.

$\mathfrak{f}$

$$
1,640,708
$$

$2,268,843$

$4,563,291$
$\%$

57

67

71

As regards the provincial distribution of elucational expenditures, the Cape of Good Hope took the lead with $£ 663,662$ out of a total of $£ 1,640,708$ disbursed in 1911-12, followed by the Transvaal with $£ 628,625$, the Orange Free State with $£ 192,948$, and Natal with $£ 155,473$. In 1919-20, however, the allocation was as follows:Transvaal $£ 1,759,114$, Cape of Good Hope $£ 1,676,208$, Orange Free State $£ 671,921$, and Natal $£ 456,048$.

The eost per scholar in respect of the provincial expenditure on education varies considerably in the several provinces according as the entire cost is borne by the Provincial Revenue Fund or merely grants-in-aid of the expenditure incurred by school boards are made. The Cape of Good Hope and the Transvaal constitute the most appropriate examples within the limits of the Union, for a comparison of this nature. 
Cost of Education of White Scholars in the Cape of Good Hope and the TransvaAl in 1917.8

Provincial Exp. on Education.

$$
\text { Cost per }
$$

l'rovince.
Cost per head of White Population. i s. d.

Cape of Good Hope scholar. f s. d. Transvaal ...

8110

$\begin{array}{lll}13 & 19 & 8\end{array}$
Total Cost of Education.

Cost per Cost per hoad White of White Scholar. Population. $£$ s. d. $\quad$ s. d.

$\begin{array}{llllll}11 & 0 & 8 & 2 & 2 & 4\end{array}$

$\begin{array}{llllll}13 & 9 & 8 & 2 & 3 & 7\end{array}$

In respect of the provincial expenditure, the cost per white seholar or per head of the white population is much lower in the Cape Province than in the Transvaal, due to the fact that in the former provinee fees are charged to the extent of about 25 per cent. of the total expenditure on school education whereas in the latter the entire cost is met from the general revenue of that province. But even with regard to the total cost of education, the eosts per white seholar and per head of the white population are slightly in favour of the Cape of Good Hope, which may be attributed to the higher salaries of teachers prevailing in the Transvaal.

B. Higher Education. Supervision of all higher education is vested in the Union Government and is excersised by the Union Department of Education, which makes grants-in-aid to the various educational institutions falling within the seope of its jurisdietion.

Until April 2, 1918, the Union was served by one university only-the University of the Cape of Good Hope. This university was, by its Act of incorporation, confined to the functions of an examining body, the teaching being undertaken by the University Colleges, of which there were eight. These eolleges prepared students for the university examinations. ${ }^{9}$

The University Acts of $1916^{111}$ provided for the ineorporation of the South African College as the University of Cape Town, of Victoria College as the University of Stellenbosch, and of the University of the Cape of Good Hope as the University of South Africa with headquarters at Pretoria, embracing six constituent eolleges. ${ }^{11}$

The Union Department of Education also supervises the training and eertification of teachers for the high schools, the conduct of technical and commercial examinations for the National Advisory Board. and the activities of the industrial schools and certified institutions under the law regarding protection of children. ${ }^{12}$

\footnotetext{
8 O.Y.B. 1918, p. 274.

9 O.Y.B. 1918, p. 251.

11 O.Y.B. 1918, p. 251.

in Acts 12, 13 and 14 of 1996.

12 O.Y.B. 1919 , p. 105.
} 
The funds required for the operation of the universities and eolleges are derived from three sources:-

(a) grants-in-aid from the Union Government, varying from 47 per cent. of the total cost of one university to 81 per cent. of that of another;

(b) fees from students, varying from 30 to 12 per cent. of the total cost :

(c) investment of endowment funds.

In the financial year 1919-20 the Union Government contributed the sum of $£ 148,640$ towards the maintenance of universities and colleges, or 60 per cent. of the total cost, and students' fees furnished

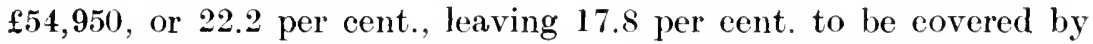
the income from endowment funds. The total cost per student during that year was $£ 101,{ }^{13}$ so that the east to the Union Government was about $£ 61$ per student.

In contrast with the substantial and continuous inerease in the expenditure on primary and secondary education, the expenditure on higher education was subject to fluctuations, as shown in the following table. ${ }^{14}$

Expenditure on Higher Education.

Fiscal Year.

1911.12

1912.13

1913.14

1915.16

1917.18

$1919 \cdot 20$

\section{Expenditure per}

Total
Expenditure.
$\mathfrak{f}$
107,888
159,252
128,250
110,288
133,482
198,824

capita of

White Population.

$\begin{array}{rr}\text { s. } & \text { d. } \\ 1 & 8 \\ 2 & 5 \\ 1 & 11 \\ 1 & 7 \\ 1 & 10 \\ 2 & 8\end{array}$

Expenditure per per capita of

Total Population.

d.

4.3

6.2

4.9

4

4.7

6.6

The irregularity of the expenditure on higher education during the period under consideration is attributable to several factors :-

(1) In some years speeial building grants are made to certain colleges. For example, the high mark of 1912-13 is in greater part explained by the building grants of $£ 15,000$ and $£ 12,000$ which were made to the Victoria and Rhodes University Colleges respeettively in that year, and by the government contribution of $£ 5,000$ to the building fund of the University of the Cape of Good Hope. ${ }^{15}$

\footnotetext{
13 Aurlitor-General's Report 1919-20. p. 145.

14 O.Y.B. 1918, P. 694 and O.Y.13. 1920.
} 
(2) The deerease in expenditure during the first two years of the War was oceasioned by the policy of economy necessitated by the shrinkage of certain sources of revenue and the increase in the interest eharge.

(3) The considerable advance in expenditure during the last two years of the deeade was the result of the inereased cost of living and of materials.

\section{(2) Agriculture.}

The Union Department of Agrieulture exereises control over the agrieultural activities of the Government. The Minister of Agriculture is responsible to Parliament for the policy and aets of the department. The Secretary for Agrienture is the permanent departmental head and is assisted by two Under-Seeretaries, one of these being in charge of Agrieulture proper and the other of Agricultural Education.

(il) Agriculture Proper.-The activities in respeet of agriculture proper are maintained by a number of Divisions and Offices presided over by scientific and technical officers. There are 15 divisions, 2 offices and a library. The ehief divisions are those of (a) sheep and wool, charged with the eradication of seab and the promotion of sheep and goat industries by advising upon the grading and management of sheep and goats, $(b)$ the Veterinary Division, dealing with the prevention of the introduetion of eontagious diseases of live stock into the Union, with the eradication of such diseases as are present. and with the protection of live stock against enzootie diseases by inoculation and other means, and $(c)$ the Division of Veterinary Research. Other divisions are those of Botany and Plant Pathology, Entomology, Tobaceo and Cotton, Viticulture, Horticulture, Dairying, Dry-Farming, Co-operation, ${ }^{16}$ etc. The names of these divisions sufficiently indicate the range of activities within the jurisdietion of the department of agriculture.

During the decade from May 31, 1910 to March 31, 1920, the sum of $£ 302,420^{17}$ was expended from loan funds for agrieultural purposes. The annual expenditure from revenue, however, constitutes the main item for eonsideration.

15 O.Y.13. 1918, p. 415.

it S.Y.B. 1914-15, p. 232, and O.Y.B. 1920. 
Ordinary Expenditure on Agriculture Proper. 18

\begin{tabular}{|c|c|c|c|c|c|c|}
\hline Fiscal & Year. & & $\begin{array}{c}\text { Total } \\
\text { Expenditure. }{ }^{19}\end{array}$ & $\begin{array}{l}\text { Expenditure per } \\
\text { capita of } \\
\text { White Population. }\end{array}$ & $\begin{array}{r}\text { Expe } \\
\text { eq } \\
\text { Total }\end{array}$ & $\begin{array}{l}\text { nditur } \\
\text { apita } \\
\text { Popul }\end{array}$ \\
\hline & & & $£$ & B. d. & & s. d. \\
\hline 2 & $\ldots$ & $\ldots$ & 538,104 & $8 \quad 5$ & & 1 \\
\hline & ... & $\ldots$ & 399,936 & $\begin{array}{ll}6 & 0\end{array}$ & & 1 \\
\hline 6 & $\ldots$ & $\ldots$ & 351,029 & $\begin{array}{ll}5 & 1\end{array}$ & & 1 \\
\hline & $\ldots$ & $\ldots$ & 455,582 & 64 & & 1 \\
\hline & $\ldots$ & $\ldots$ & 557,281 & 76 & & 1 \\
\hline
\end{tabular}

The expenditures on agriculture present the phenomenon, peculiar to several items of expenditure, of a steady decrease up to a certain period, generally 1915-16, followed by an annual inerease. This phenomenon is mainly to be aseribed to the policy of retrenchment which was practised in several of the government departments subsequent to the establishment of the Union, in order to secure the economies rendered capable of attainment by the consolidation of the four colonial departments into the single Union department as well as those rendered necessary by the declaration of war, followed by the granting of war bonuses to eivil servants and a general inerease in salaries and wages.

However, in spite of the substantial deeline in the purchasing power of money in recent years, the absolute expenditure for 1919-20 is only slightly in exeess of that in 1911-I2, whereas the per capita expenditure has been diminished by about 10 or 11 per cent.

(b) Agricultural Education.-Agricultural Schools and Experiment Farms have been established at several points in the Union. There are five Agrieultural Schools, seven Experiment Stations, and three Stud Farms. The farms on which the schools are situated are well stocked, well equipped, and representative of the agricultural conditions of their respeetive areas, and they cnable the breeding of pedigree live stock and the eultivation of land to be undertaken on a suitable seale for the benefit of students and the improvement of the stock of the country. The laboratory and class-room aceommodation and equipment provided suitable faeilities for a sound

18 This does not include the expenditure incurred in connection with the Government Guano Islands which fall within the jurisdiction of the Department of Agriculture, as such is treated in conjunction with the revenue from that source. 1920.
19 O.Y.B. 1918, p. 695, and O.Y.B. 
training in the science of agriculture. In addition to their educa. tional duties the staff perform some extension, experiment and researeh work, and it is contemplated that in due course three more or less independent branches will be developed at each institution for college work. experiment and research work, and extension work. ${ }^{21}$

('onsiderable progress has been made in developing extension work. During the financial year 1917-18 the staff of the agrieultural schools undertook 400 lectures and demonstrations, ehiefly at agricultural shows, at meetings of agricultural bodies and at other gatherings in the rural districts. It is estimated that during the same financial year the sehools dealt with about 10,000 inquiries of farmers and others seeking advice and information upon subjeets connected with agriculture. ${ }^{21}$

A large part of the work on the farms attached to the schools is devoted to experimental work under the direction of specially trained officials. These farms are more or less representatively situated in the various provinees, so that the requirements of the greater part of the Union are satisfactorily complied with. Experiments are conducted mainly in animal husbandry, field husbandry, and fertilizers and manures. In addition to the field trials laboratory research is also undertaken. Arrangements are made at each of the schools for the analysis of soils and agricultural materials, and for the testing of milk and seeds required by farmers.

Scholarships are annually awarded to students for special study abroad in agriculture, veterinary seience, and other related seiences, for the purpose of training promising young South Africans to fill posts in the Union Department of Agrieulture..

Expenditure on Agriculturat Education. ${ }^{2: 2}$

\begin{tabular}{|c|c|c|c|c|c|c|}
\hline Fiscal & Tear. & & $\begin{array}{c}\text { Total } \\
\text { Expenditure. } \\
\mathfrak{f}\end{array}$ & $\begin{array}{l}\text { Expenditure per } \\
\text { per capita of } \\
\text { White Population. } \\
\text { s. d. }\end{array}$ & $\begin{array}{r}\text { Expe } \\
\mathrm{e} \\
\text { Total }\end{array}$ & $\begin{array}{l}\text { enditure per } \\
\text { apita of } \\
\text { Population. } \\
\text { d. }\end{array}$ \\
\hline 1911.12 & $\ldots$ & $\ldots$ & 89,247 & 15 & & 3.6 \\
\hline $1913-14$ & $\ldots$ & $\ldots$ & 111,487 & 18 & & 4.3 \\
\hline $1915-16$ & $\cdots$ & $\ldots$ & 73,238 & 11 & & 2.7 \\
\hline $1917-18$ & $\ldots$ & $\ldots$ & 81,778 & 12 & & 2.9 \\
\hline $1919 \cdot 20$ & $\ldots$ & $\ldots$ & 117,410 & 17 & & 4 \\
\hline
\end{tabular}


The expenditure on agrieultural education was likewise affected by the War. The expenditure on salaries was subject to a steady increase as the result of expansion of the teaching staff and, subsequent to 1917 , of the war bonus and the rise in salaries; but substantial economies were effected ruring the first years of the war in respect of experimental work and maintenance charges. 'The increased cost of supplies made itself felt after 1917, but in spite of that the maintenance charges for 1919-0) were $854,0.23$ as compared with $£ 71,510$ in $191: 3-14$.

\section{(3) Promotion and Regulation of Industiy.}

At the establishment of the Union, provision was made for a Department of Commerce and Industries in addition to the Department of Mines which was inherited from the Colonies. On a rearrangement of portfolios, however, the Department of Commerce and Industries was abolished in 1912, and the portfolio of Mines was extended to include industries. the title being altered to that of "Mines and Industries."

The activities of the Department of Nines and Industries may be characterized as follows:-control of mining and prospecting : mining enginecring; issue of elaim licences, prospecting permits, mineral leases, alluvial diamond licenees; regulations governing underground and surface work on mines; registration of nining titles; medical examination of applieants and periodical examination of all mine labourers, and other matters generally connected with miners' phthisis ; control and payment of miners' phthisis compensation : geological reports and surveys; inspection of mines and factories; prevention and settlement of industrial disputes: labour employment bureaus ; wages boards ; control and regulations of industries:; industrial research and the publication of technical, seicntific and statistical information.

In 1916 an Industries Advisory Board was appointed. consisting for the most part of business men and designed to adrise the Minister in regard to the industrial development of the Union and especially on questions of an economic eharacter. The necessity for scientific methods of research and management in regard to industrial development was also recognised, and after negotiations with representatives of the various Scientific Socicties throughout the Union, a Seientific and Technical Committee was created in 1917. In the following year these two institutions were amalgamated under the title of the Advisory Board of Industry and Science. 


\section{Expenditure on Mines and Industries, ${ }^{23}$}

Expenditure per Expenditure per

Fiscal Year.

Total capita of capita of Expenditure.

White Population. Total Population.

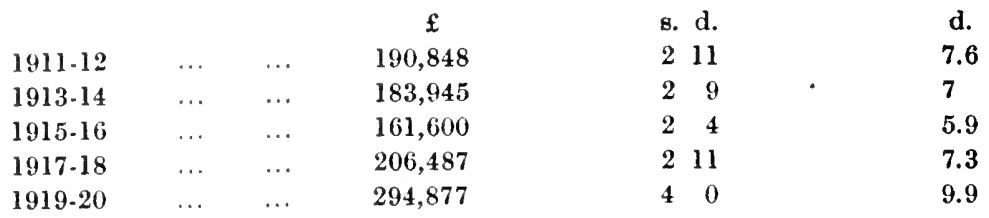

The expenditure on mines and industries was subject to reduction in the carly stages of the war in consequence of a policy of economy, wherever possible, but the introduction of the general war bonus in 1918 and of the rise in salaries and wages in 1919, in addition to the expansion of the staff, occasioned an enhancement of expenditure to a considerable extent, the amount for 1919-20 exceeding that of 191112 by more than 50 per cent.

The most important items of expenditure under this heading are :-

(a) engineering, which absorbs about $£ 50,000$ per annum;

(b) mining commissioners, who occasion an annual expenditure of about $£ 35,000$;

(c) contribution towards expenditure incurred in the prevention of miners phthisis and in the payment of compensation to victims of that disease, which amounts on an average to about $£ 50,000$ per annum. 


\section{CHAP'LR 4.}

Public Healti. Dependent and Defective Classes. Native AfFitrs.

(1) Public Health.

No specific provision was made in the Union Constitution for the administration of the public health laws in force in the constitucnt Colonies at the establishment of the Union, but that function was interpreted as falling within the juriscliction of the Union Govemment and was entrusted to the Department of the Interior, which engaged the services of a Medical Offeer of Health for the Union and assistant health officers in the larger towns.

In 1917, after a conference of Government health officers, a sub-department of Public Health was constituted in the Department of the Interior under the direction of the Medical Officer of Health. who had formerly occupied an advisory position only. The importance of this phase of governmental activity was realised more fully during the latter part of the decade under consideration, especially in view of the ravages of the Influenza Epiclemic in 1918. Consolidating legislation was introduced in 1919 and provision was made for an independent Department of Public Heaith under the control of a Minister of Public Health.

The Department of Public Health deals with a variety of matters, such as public health in general, contagions diseases and lock hospitals, inspection of areas of local authorities, water supplies and drainage schenes, food adulteration, vaceination, registration of medical practitioners, chemists, dentists, midwires and trained nurses, ${ }^{1}$ etc.

For certain purposes, such as the contiol of sanitation, outbreaks of infections disease, and other measures undertaken in the interests of the health of any urban community, the local anthorities have health officers and health departments with local jurisriction.

With regard to the performance of the health and medical services for which the Government is responsible in the various districts of the Union, medical officers known as district surgeons are generally

1 O.Y.B. 1918, p. 103. 
employed, those in the large centres devoting all their time to the work, but the large majority engage their services to the Government concurrently with their private practice.

The expenditure on pubhe health has been subject to violent flucthation as a result of abnormal conditions.

\begin{tabular}{|c|c|c|c|c|c|c|}
\hline Fiscal & Year. & & $\begin{array}{l}\text { Expenditure on } \\
\text { Public Health. } \\
\qquad \mathfrak{L}\end{array}$ & $\begin{array}{l}\text { Expenditure per } \\
\text { capita of } \\
\text { White Population. } \\
\text { s. d. }\end{array}$ & $\begin{array}{r}\text { Expe } \\
\text { ca } \\
\text { Total }\end{array}$ & $\begin{array}{l}\text { nditure per } \\
\text { pita of } \\
\text { Population. } \\
\text { s. d. }\end{array}$ \\
\hline $1911-12$ & $\ldots$ & $\ldots$ & 101,453 & 17 & & $\begin{array}{ll}0 & 4\end{array}$ \\
\hline $1913-14$ & & $\ldots$ & 105,229 & 17 & & $\begin{array}{l}0 \quad 4 \\
\end{array}$ \\
\hline $1915-16$ & $\ldots$ & $\ldots$ & $\mathrm{I} 12,199$ & $17 \frac{1}{2}$ & & $\begin{array}{ll}0 & 4.1\end{array}$ \\
\hline $1917-18$ & $\ldots$ & & 133,973 & $110 !$ & & $\begin{array}{ll}0 & 4.7\end{array}$ \\
\hline $1918-19$ & $\ldots$ & & 376,096 & 52 & & $\begin{array}{ll}1 & 1\end{array}$ \\
\hline $1919-20$ & $\ldots$ & $\ldots$ & 234,006 & 32 & & $0 \quad 7 \frac{1}{2}$ \\
\hline
\end{tabular}

The policy of economy occasioned by the War did not result in a reduction of this item of expenditure in the early stages of hostilities as in the case of certain other items, but it succeeded in checking the rapid growth likely to result from an expansion of activities. The abnormal expenditure for 1918-19 was caused by the Spanish Influenza Epidemic which made its appearance in September, 1918, and affected the whole of the Union. By the end of 1918 the epidemic had been brought under control, but periodical outbreaks of minor significance continued and necessitated an additional expenditure of $£ 70,282^{3}$ during the financial year 1919-20. A portion of the increase in this expenditure is of course attributable to the war bonus and the rise in salaries and wages.

\section{(2) Expenditure on the Dependent and Defective Classes.}

(a) Hospitals. - In accordance with the provisions of the South Africa Act, ${ }^{4}$ hospitals and charitable institntions were placed under the control of the Provincial Administrations. In the Cape of Good Hope and the Orange Free State all state-aided hospitals, dispensaries, or convalescent homes are under the direct control and management of hospital boards, which are financed by Provincial subsidies calculated on the amount of their revenue derived from patients' fees and voluntary contributions and bequests. In Natal four hospitals are directly controlled by the Provincial Administration; and in addition to these there are seven other institutions

\footnotetext{
1920 .

2 O.Y.B. 1918, p. 694, and O.Y.B. 3 Auditor-General's Report for 1919 . 1920 , p. 228 .

4 Sec. 85.
} 
which receive financial assistance from provincial funds but are controlled by other than Government authority. In the T'ransvaal nine hospitals are maintained by the Province, and nine others supported by grants-in-aid. ${ }^{5}$

The expenditure on hospitals and charitable institutions represents on an average about $S$ per cent. of the total ordinary expenditure of the Provinces.

(b) Mental Asylums.-The direct control of mental asylums is vested in the Union Government, and in particular in the Department of the Interior, the chief officer being known as the commissioner of mentally disordered or defective persons. Provision has been made for the appointment of boards to visit and report on the institutions and the welfare of the patients."

There are eight mental asylums in the Union, which oecasion an annual expenditure of more than $£: 00,000$ by the Government.

(c) Leper Institutions.--The leper institutions ave likewise under the control of the Union Government. Compulsory segregation of lepers is enforced by legislation in each province. All cases of leprosy are to be reported to the Government, and where the nature of the discase has been fully establisher, the patients are remover to one of the leper institutions.

(d) Poor Relief.-Poor relief falls mainly within the jurisdiction of the Provinces, the Union Government granting financial assistance only on exceptional occasions. For example, in the rear 1916-17 the Union Government contributed $£ 64,563^{7}$ towards the relief of distress from loan funds, necessitated by the prevalenec of a severe drought in certain regions of the country ; and in 1913-14 the Government disbursed $£ 15,305^{-8}$ from revenue for poor relief. In general, howerer; the Provinees alone are active in this respect.

There is no poor law in any of the Provinces, and the greater part of assistance rendered to persons in poverty and distress is that afforded by the various benevolent institutions. The annul expenditure on poor relief by the Provinees amounts merely to about $£ 50,000$.

Summary of expenditure.-The expenditure on the dependent and defective classes represents a comparatively large burden, as evidenced by the following table:- ${ }^{9}$

5 O.Y.B. 1918, pp. $235 \cdot 236$.

5 Ibid. p. 239.

7 O.Y.B. 1918 , p. 716.
8 Ibid, p. 694. 1920.
9 Ibid, p.p. $69+$ and 708, and O.Y.P. 


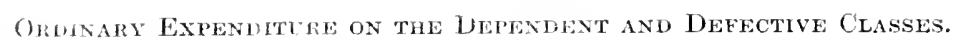

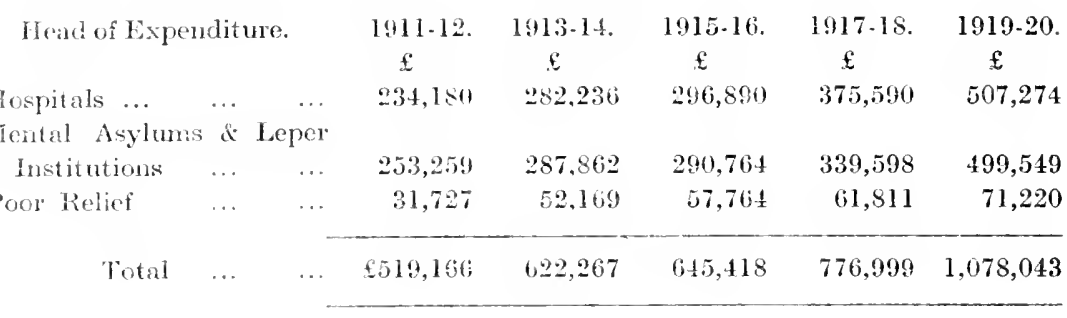

The cxpenditure on the dependent and defective elasses has been aubject to a continuous inerease, but the natural growth was crmen hat checked during the first two rears of the war in view of the need for cconomy. Towards the cnd of the war, however, the increased cost of living and of supplics oreasioned a considerable abrence in expenditne. The extraordinary increase of 100 . per eent. dning the period under review is mainly atributable to the depreaistion in the purchasing power of money, but to a lesser extent also to the extusion of goremmental activity in such matters as the care of the sick, the dofectre, and the poor.

\section{PER CAPITA FXPENDITUTI.}

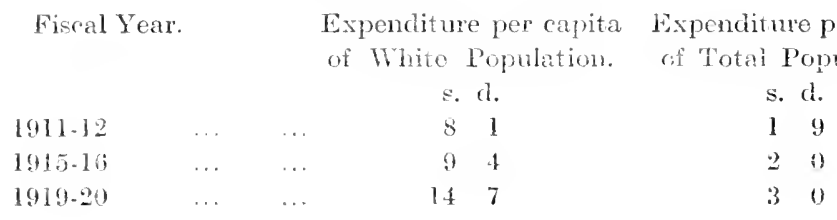

(i) Sulie Affeins.

A bapante Depatment of State under a Minisicr of Native Afrairs was fstablished at the consummation of the Luion. This department is chaged with the administration of the Yative Territories in the Trankei, Zululand, and chemhe. inchuling native reserves; the dirction and supervision of the recruitment of native labour, especially for mining purposes ; the control of native taxation and the pass system; the gencral supervion of all matters concerning the welfare and interests of the native races of the Union."

'The departinental organization comprises $(a)$ the Head Office at Pretoria moler the Secretary for Native Allais, with an UnderSecretary and ntaff; $(b)$ the Chici Magistrate at Untata, controlling the Truisken Territories (with 27 magistracies); (c) the Chief Sative ('ommissioner at Pietermaritzburg, dealing with native 
administration throughout the Natal Province, including Zululand; and $(d)$ the Director of Native Labour, with his headquarters at Johannesburg, controlling the registration and pass system on the Rand. ${ }^{11}$

A large number of hereditary and appointed ehiefs and hathnen are in receipt of salaries and allowanees from the Government, either provided for in treaties of annexation or paid for services rendered to the Government. These officers act and report through the magistrates and the officers of the department, and are in charge of tribes, scetions of tribes. Or loeations, as the case may be. The anmul expenditure in iospect of subsidies and allowanees to chiofin and headmen is about $f: 0,000$. $^{1:}$

Since the inauguration of a deninite dipping poliey by the Government, the responsibility for the crection, maintenanes and eontrol of some hundreds of̂ dipping tanks in natire locations and reserves has devolved on the Department of Native Affairs, acting in this matter on behalf of the Department of Agriculture, levying and collecting rates to meet the capital outlay and the cost of maintenanes in this connection. ${ }^{13}$

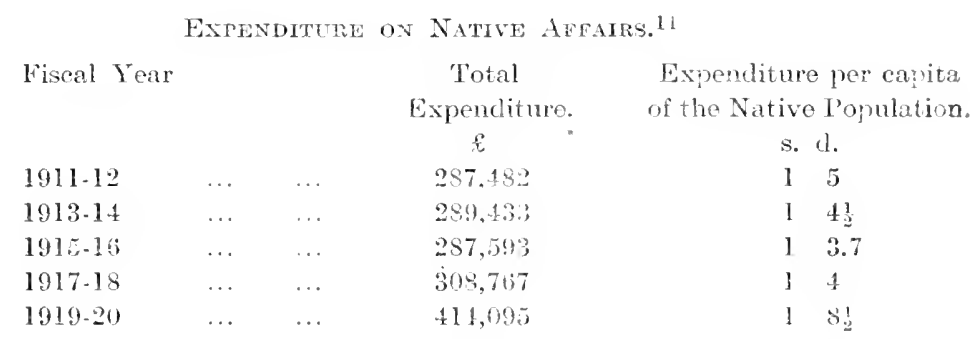

The expenditure on native affairs was kept well in eheck until about 1917 , subsequent to which the general war bonus and the rise in salaries and wages caused a substantial inercase in expenditure. Durng the period under consideration the per capita expenditure: in respect of the native population was inereased by about 20 per. cent., as compared with an increase of 44 per eent. in the totit expenditure.

11 O.Y.B. 1918, \%. 194.

12 O.Y.B. 1918. p. 697.

13 Ibid, p. 195. 140.x.13. 1918, P. 697 and O.Y.P3 1920 . 
CHAPTER 5.

\section{Public Debt Charge.-Mscellaneous Expenditure.}

\section{(1) Public Debt Charge.}

The public debt charge eomprises the following items:

(a) the net interest charged to the unproductive debt ;

(b) the contributions to the sinking fund provided for by Colonial statutes;

(c) the cost of management.

In the Union of South Africa, where the Central Government undertakes the management of the railways, harbours, telegraphs, telephones, land banks, land settlement, forestry, irrigation works and irrigation loans, ete., the gross interest eharge represents a considerable amount and has given rise to numerous instances of confusion, misconception, and anxiety. In the absence of scientufic accounting, the only available means of computing the net interest eharge on the unproductive debt is to deduet from the gross interest charge the interest paid by the Railway and Harbour Administration on that part of their capital ${ }^{2}$ whieh is included in the gross public debt, the interest on Government loans to settlers, irrigation boards, land bank, ete., and the small Post Office surplus which may, for the purpose under consideration, be regarded as interest on the eapital investment in respeet of the posts, telegraphs, and telephones.

Redemption is provirled for by various Colonial statutes, the annual redemption payments being generally in excess of $£ 600,000$. The most important of such redemption payments are those made in connection with the guaranteed loan of $£ 35,000,000$, granted by the British Government to the Transvaal and the Orange Free State in 1903 (the year after the close of the Boer II ar) for the purpose of recoustruction, and the guaranteed loan of $£ 5,000,000$ by the British Government to the Transvaal in 1907, on both of which an annual redemption of 1 per eent. is due, eomprising the sum of $£ 400,000$.

c.f. Part 3: Public Debt.

2 The interest paid into the Treasury by the Administration on capital con- tributed out of general revenue is treated as commercial revenue in Part 2. 
Public Debt Charge.

\begin{tabular}{|c|c|c|c|c|c|c|}
\hline \multicolumn{2}{|l|}{ Head of Expenditure. } & $\begin{array}{c}1911 \cdot 12 . \\
\mathfrak{E}\end{array}$ & $\begin{array}{c}1913 \cdot 14 \\
f\end{array}$ & $\begin{array}{c}1915 \cdot 16 . \\
f\end{array}$ & $\begin{array}{c}1917.18 \\
f\end{array}$ & $\begin{array}{c}1919 \cdot 20 \\
£\end{array}$ \\
\hline Net Interest Charge & $\cdots$ & $1,182,539$ & $1,183,598$ & $1,573,050$ & $2,113,866$ & $2,485,698$ \\
\hline Redemption & $\ldots$ & 639,681 & 647,432 & 588,864 & 560,710 & 498,253 \\
\hline Cost of Management & $\ldots$ & 25,838 & 30,918 & 22,460 & 23,961 & 27,078 \\
\hline Total Debt Charge & $\ldots$ & $1,848,058$ & $1,861,948$ & $2,184,374$ & $2,698,537$ & $3,011,029$ \\
\hline
\end{tabular}

The great increase in the interest charge was occasioned by the debt of 30 million pounds incurred in connection with the war. 'The decrease in the contributions to the sinking fund out of revenue, after 1914 , is to be attributed to the need for cconomy, the redcmption payments being confined, as far as possible, to statutory requirements.

During the period uncler review, the net interest charge was more than doubled and the total debt charge increased by about 60 per cent. Such was the revolutionary effect of the war.

Per Capita Expenditure.

Fiscal Year.

$\begin{array}{cccc} & & & £ \\ 1911-12 & \ldots & \ldots & 1,848,058 \\ 1915-16 & \ldots & \ldots & 2,184,374 \\ 1919-20 & \ldots & \ldots & 3,011,029\end{array}$

\begin{tabular}{|c|}
\hline $\begin{array}{c}\text { Per capita of } \\
\text { White } \\
\text { Population. }\end{array}$ \\
\hline f s. d. \\
\hline $\begin{array}{lll}1 & 8 & 10\end{array}$ \\
\hline $\begin{array}{lll}1 & 11 & 8\end{array}$ \\
\hline $\begin{array}{lll}2 & 0 & 8\end{array}$ \\
\hline
\end{tabular}

\section{Per capita of \\ Total \\ Population.}

s. d.

$6 \quad 2$

$6 \quad 8$

$8 \quad 5$

\section{(2) Miscellaneous Expenditures.}

A. Survey of Diagrams.-Each Province has a Surveyor-General who is charged with the examination of the diagrams necessary for effecting the transfer of property. This is due to the fact that the system of land registration in the Union is based on the principle that every deed granting or conveying landed property either is to have a diagram of the property being conveyed attached to such deed or is to refer back to a previous deed with diagram attached. The area of the land, its dimensions, locality, deseription of its boundaries, etc., are all clearly set forth in the diagram which is referred to in, and may be taken to be a component part of, the deed of conveyance. The necessity for accuracy in the survey upon which the diagram is based is therefore obvious, and, to insure this, no diagram is aecepted for registration with a deed of grant or transfer unless signed by a surveyor duly admitted to practice as such in that 
Province of the Union in which the land being dealt with is situated, and approved by the Surveyor-General of that Province. ${ }^{3}$

In the Transvaal no charge is made by the Government for the work of examining for approval diagrams of private property, whereas in the other Provinces certain fees are imposed by law or regulation, varying according to the nature of the work. ${ }^{4}$

The expenditure in ennnection with this survey of diagrams has been fairly stationary and is almost entirely an outlay on salaries, wages and allowances.

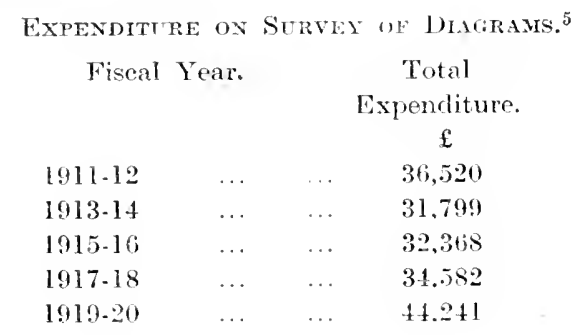

B. Registration of Decds.- In the Cape of Good Hope there are four offices for the registration of deeds, each office being under the control of an officer called the Registrar of Deeds, and undertaking registration in respect of that portion of the Province which is specially assigned to it. In each of the other three Provinces there is only one Deeds Office. ${ }^{6}$ These Deeds Offices secure quite a considerable amonnt of revenne in the form of transfer duties, stamp duties and fees. 'The two latter are more than sufficient to defray the expenditure of these establishments. The expenditure has been comparatively stationary during the period under review.

\begin{tabular}{|c|c|c|}
\hline Fiscal & Year. & $\begin{array}{c}\text { Total } \\
\text { Expenditure } \\
£\end{array}$ \\
\hline $1911-12$ & & 27,594 \\
\hline $1913-14$ & $\ldots$ & $2 \overrightarrow{7}, 019$ \\
\hline 1915.16 & $\ldots$ & 26,850 \\
\hline $1917-18$ & & 29,336 \\
\hline 1919.20 & $\ldots$ & 37,406 \\
\hline
\end{tabular}

(. Compensation to Colonial Capitals.-Provision was made in the Union Constitution for the payment of compensation to the Colonial Capitals for diminution of property or decline in rateable

ज.Y.B. 1918 , P. 387.

4 Itid, p. 389.

5 Ibid, p. 695, and O.Y.13. 1920.
6 O.Y.B. 1919, pp. $490-501$.

7 O.Y.B. l918, p. 69l, and O.Y.B. 1920. 
value by reason of their ceasing to be the seats of government of their respeetive colonies. In the case of Pietermaritzlourg and Bloemfontein the compensation comprises a grant to the municipal couneils of 2 per eent. per annum on their debts, as existing on the 31st of January, 1909, and as ascertained by the Controller and Auditor-General. As regards Cape Town and Pretoria, the legislative and administrative capitals respectively of the Union, no compensation was granted. One-half of such grants is to be applied to the redemption of the debts of those eities. After the tenth annual grant has been paid to any of such towns. the Govermment, with the approval of Parliament, may after due inquiry withiraw or reduee the grant. ${ }^{8}$

The amnual compensation to the old Colonial Capitals was fixed at $\mathbb{E} \pm 2,492 . ?$

D. Miscellamenits Expenses.

$\begin{array}{rccc}\text { Fiscal Year. } & & \begin{array}{c}\text { Miscellaneous } \\ \text { Expenses. }\end{array} \\ 1911-12 & \ldots & \ldots & 73,816 \\ 1913-14 & \ldots & \ldots & 160,95 ! \\ 1915-16 & \ldots & \ldots & 13,423 \\ 1917-15 & \ldots & \ldots & 35,052 \\ 1919-29 & \ldots & \ldots & 143,6126\end{array}$

Commercial Expenditures. -The commercial expenditures, i.e. expenditures in respect of the commereial enterprises of the Union Govermment such as railways, harbours, post office, telegraphs, telephones, etc., are treated in comeetion with commercial revenues in Part 2.

8 S.A. Act, sec. 133.

S Appropriation Aceomuts 1:11:17.
10 O.Y.B. 1918, pp. tist and 705, and O.Y.1. 1920

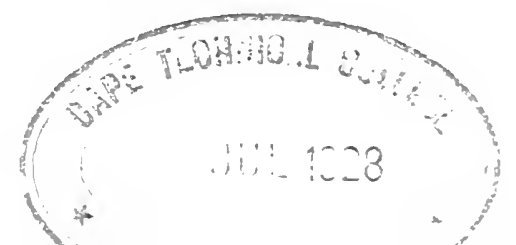





\title{
PART II.
}

\section{REVENUES.}

\section{A. COMMERCIAL REVENUES.}

1. Industries.

\author{
CHAP'TER 1.
}

\author{
RAILWAYS.
}

Introduction.-In South Africa railway construction was initiated by private enterprise in 1859, Cape Colony being the pioneer and Natal a elose second. At the time of the discovery of the diamond mines in Griqualand West, in 1870, the only completed lines of railway in South Africa consisted of 63 miles of private line in Cape Colony and two miles of private line in Natal. Thus, on account of the lack of private initiative and the slow progress of railway development under private ownership and the need for transportation facilities, the State was prompted to make an incursion into the realm of railways. The Cape and Natal Governments decided to undertake the railway development of the country and negotiated the purchase of the private lines in existence. The foundation of Kimberley and the diamond industry and the declaration of the Rand as a public goldfield, followed by the sudden birth of Johannesburg and the rapid conversion of the barren uplands around it into the greatest industrial centre of South Africa, served as powerful agencies in stimulating the railway development under State control.

Although the great bulk of railway extension has been undertaken by the State, private companies have also participated to a certain extent. At the establishment of the Union in 1910 the railways within the four original colonies comprised 7,041 miles of Govermmentowned line and 545 miles of privately-owned lines, ${ }^{1}$ serving an area of 470,000 square miles and a white population of 1,255,545. By 1919 the mileage of Govermment lines had been increased to 9,542 , representing an increase of 35 per cent. during the nine-year perrod. 
whereas the mileage of private lines declined to 507,38 miles of line having been taken over by the Union Government."

Administration of the Union Government Railuays.-In accordance with the provisions of the South Africa Act all the railways belonging to the four Colonies at the establishment of the Union were transferred to the Union Government, and the control and management thereof was rested in a Board consisting of three commissioners, appointed by the Government, with a Minister of State as chairman. Each commissioner holds office for a period of five years and is eligible for reappointment. ${ }^{3}$

The Railway Board served as the main organ of control and management in respect of the South African Railways until 1916 . when legislation was introduced to make further provision as to the administration, operation, control and management thereof. In accordance with this legislation the railways of the Union are to be adininistered and operated under the control and authority of the Union Govermment. This is exercised through the Minister of Railways who is adrived by the Board. The management and operation of the railways are, subject to the control of the Minister, rested in the General Manager, who is governed by such regulations as the Hinister may from time to time frame after consultation with the Board. ${ }^{+}$

Cnder the new system the Board was reduced to an advisory body. The Board is to advise the Hinister upon all matters of policy concerning the administration and operation of the railways, and is also empowered to take such measures and secure such information as may enable Parliament to be informed and satisfied as to the expediency or inexpediency of undertaking the construction of a proposel new line. Every proposal for the construction of any line of railway, before being submitted to Parliament, is to be considererl by the Board, which is to report thereon and to advise whether the proposed line of railway should or should not be constructed. If any such line is constructed contrary to the advice of the Board, and if the Board is of opinion that the revenue derived from the operation of such line will be insufficient to defray the costs of operation and maintenance and of interest on the capital invested therein. it is to frame an estimate of the annual loss which, in its opinion, will result from such operation. Such estimate is to be examined by the Controller and Auditor-General, and when approved by him the amount thereof is to be paid over annually 
from the Consolidated Revenue Fund to the Railway and Harbour Fundi. ${ }^{5}$

This safeguard against the construction of unremuncrative lines (which is a serious disadvantage of government ownership in a country where representative government prevails) was prompted by certain discreditable incidcnts in colonial railway history, particularty in the Cape Colony. ${ }^{6}$ In a democratic country the success of Government ownership of railways is jeopardised by popular requests for unprofitable extensions. In the legislative asiscmbly the representatives will display all the eloquence at their command in the presentation of the claims of their respective electoral districts for new lines, whether there is any likelihood of such proving to be remunerative or not. 'The dianger' emerges when the Government is not so firmly entrenched as to be able to withstand the demands of the legislature. Under a system of responsibie gorernment where the excutive is dependent upon the riajority vote of the legislature, the menace to success is intensined. Up to the present this safeguard has proved to be very effective in exercising a restraining influence upon the activities of Parliament with regard to extensions. In Prussia and Switzerland the disadvantagcous effects of the inability on the part of the Government to withstand the popular demands for extensions into unremunerative areas and for better stations in conncetion with beantifying projects were clearly discemible in the years just precaling the war.

Principles of Railway Administration in South Africa.-The main principles of railway administration in the Union may be briefly summarized as follows:-(1) the railways are to be administered in accordance with business principles, due regard being had to agricultural and industrial development within the Union and to promotion, by means of cheap transport, of the settlement of an agricultural and industrial population in the inland portions of all provinees of the Union $;^{i}$

(2) the cost principle is to serve as the basis of the system, the total earnings to be no more than are sufficient to meet the nceessary outlays for operation, maintenance, improvement, depreciation, and the payment of interest due on capital $;^{\top}$

(3) the uniformity of rates is to be maintained by means of an equalization fund, into which are to be paid all profits earned from

5 S.A. Act, sec. 130.

6 Brand: The Union of South Africa.

7 S.A. Act, sec. 127 p. 95 . 
time to time and from which any deficits that may oceur are to be met, with a view to avoiding, as far as possible, a disturbanee in trade ;

(4) the Railway Achministration is to be an independent organization free from political interference;

(5) the railway finances are to be treated in a separate budget and not subjected to manipulation by the Treasury; and

(6) the loss arising ont of the operation of unprofitable lines constructed by authority of Parliament and eontrary to the adviee of the Railway Board is to be paid ont of general revenue.

The Act of Union not only constitutes the railways a complete and ristinct service of the Union Govermment, but it also provides that the railway revenues and expenditures shall be aecounted for entirely separate from those of other government departments. The Department of Railways is an independent department subject to the authority of the Minister of Railways, who is responsible to Parliament for the activities of the department. Provision was made in the Constitution for a Railway Fund, into which are to be paid all revenues raised or reecived by the Covernment from the administration of the railways, such fund to be appropriated by Parliament for the purposes of the railways. ${ }^{9}$ The administration of the Prussian railways, however, was not entrusted to a separate ministry of railways but was rested in the Minister of Publie Works. the railway department of the ministry (Eisenbahnabteilung) being under the supervision of an under-secretary." Also. the Prussian railway system did not provide for a separate hudget, but the revenues and expenditures of the state railways were aceominted for in the general budget along with the general revenues and cxpenditures, the net surplus being applied toward the payment of general expenditures. In the Swiss railways both the independent budget and the equalization fund prevail.

In respect of responiveness to public opinion. no direet provision has been made in the South Afriean lailway organization, whereas in the Prussian and Swiss railways an elaborate system of national and district advisory councils has been instituted. The powers of Parliament in respect of the railways afford the sole opportunity for responsiveness to popular demands in South Afriea, as Parliament is entrusted with the power of appropriation not only with regard to the ordinary operating expenditure but also the eapital expenditure. However, this eoncession is eonsiderably minimised by the forementioned safeguard against the construction of new lines.

8 Ibid, sec. 128.

9 S.A. Act, sec. 117.
10 Johnson \& van Metre: Principles of Railroad Transportation, p. $\mathbf{4 2 2}$. 
Departmental Organizution.-The executive head of the Railway Department is the General Manager, in whom is rested the entire management and control. Directly responsible to the General Manager are four Assistant General Managers, each eontrolling his respeetive system, the Engincer-in-Chief, and the Chief Mechanical Engineer. Under each Assistant General Manager, and directly responsible to him, are Dirisional Superintenclents, who control one of the Divisions in each system ; and under each Divisional Superintendent there are Superintendents and Assistant Superintendents (Technical, Commereial and Operating), who are placed in eharge of the staff operating the railways. ${ }^{11}$ The centralization of the South African railway organization presents a striking contrast to the decentralization prevailing in the Prussian system, where the operation of the railways was entrusted to 21 directories, each having charge of the railways in a particular section of the country.

There is a fairly close analogy between the organization of the government railways in South Africa and that of an ordinary business establishment. The Railway Board with the Minister of Railways as chairman corresponds ronghly with the Board of Directors of a private company, the former constituting the policy-determining body of the railway organization just as the Board of Directors determines all questions of general policy in eonnection with a commereial enterprise. Secondly, the status of the General Manager of the South African railways is virtually identical with that of the General Manager of a large business institution. In both cases the General Manager is the executive head, the individual entrusted with the execution of the policy determined by the Board and with the duties of administration and management.

Capital and Capitalization.-The capital of the South African railways has been derived from three different sources, namely, from loan funds, from general revenue, and from railway earnings. The great bulk of the railway eapital has been secured by means of government loans, and since the establishment of the Union that has been practically the only method of obtaining capital for the construction of new lines or of new works on existing lines.

Prior to the Union substantial sums of money were contributed to the capital fund of the railways from general revenue and railway earnings. At the establishment of the Union the contributions from railway earnings had amounted to $£ 4,358,591$, and the sum of $£ 13,014,186$ had been contributed by the colonial governments to- 
wards the eapital expenditure of the railways and harbours from general revenue. ${ }^{12}$ On the railway capital derived from railway earnings no interest is payable, hut in respect of the contributions from general revenue and loan funds interest is paid into the Consolidated Revenue Fund by the Railway administration.

At the time of Union the capital entitler to interest amounted to f75,160,228. By Narch 31, 1919, the eapital had been increased to $£ 93,908,143,{ }^{13}$ representing an increase of $£ 18,807,915$ or 25 per cent. as compared with an increase of 35 per cent. in the mileage of open ines. In 1918-19 the interest charge amounted to $£ 3,213,842$, incolving an average rate of interest of 3.4 per cent.

In respect of capitalization the South African railways show a very low figure. The average capitalization of the Union railways was $£ 9,811$ per mile in 1919 , as compared with about $£ 13,000$ in the United States, $£ \geq 3,000$ in Prussia, and $£ 50,000$ in Great Britain. ${ }^{12}$ There are several causes for this low rate of capitalization in South Africa, such as $(a)$ the low price of land, which renders it possible to recure the right of way and terminal facilities at small expense, $(b)$ a large supply of cheap unskilled labour as the result of a large native population, (c) the slight density of track mileage in view of the fact that the Union is a sparsely populated country, $(d)$ the narrow gauge prevailing in South Africa (the standard gauge being $3 \mathrm{ft}$. 6 in., and the $2 \mathrm{ft}$. gange being used in the case of some branch lines), and (e) the low interest charge of capital cluring the period of construction.

Financial Results.-Regarding the degree of coniormity of the financial results with the principles or policy adrocated in respect of a particular industry as the measure of success of government ownerwip, the South African railways will be deserving of inclusion in the list of successful government industries if over a period of ten rears an approximate balance of revenues and expenditures is attained and if miformity of rates has been realised within such a periou!

The first decade of government ownership of railways in the Union of South Africa (1910-20) is not to be subjected to a rigid test of success, inasmuch as it has proved to be most inappropriate for scientifie investigation as to success or failure for a two-fold reason. To the first place, the initial years marked the transition from the old Colonial policy of maximum profits to the new Union policy of

1. Quarterly supplement to Union Situtistics, Oct. 1920 , p. 74.

13 O.Y.B. 1919 , pp. 812 and 868 .
14 Johnson and van Metre: Principles of Railroad Transportation; pp. 111, 112 and 428 . 
balancing revenues and expenditures; and, secondly, the readjustment was no sooner accomplished than the European War appeared on the scene, which occasioned a serious disturbance in traffic, trade and costs, and effected the inconvenient disorganization of the railway finances. Taking into consideration the powerful counteracting forces set in motion by the World War, the test of success of government ownership, in its application to the South African railways during the decade in question, needs to be modified so as to accord with the abnormal circumstances and conditions. Subject to such warranted modification the test of success may be construed as prescribing merely reasonable conformity, under the stress of abnormal influences, with the principles enunciated in the Union Constitution. Any deviation that is justified by war conditions, as testified by similar tendencies all over the world, will not be discounted at its face value, but allowances will be made as nearly as possible in proportion to the necds of the case.

(1) The Period of Reorganization (1910-1913).-The first problem of the railway authorities was the gradual elimination of the colonial practice of using the State railways as agencies of taxation. The policy of making gradual reductions in rates and fares until the approximate balancing of revenues and expenditures had been accomplished was initiated at an early stage. Reductions were made in compariatively rapid succession. By the end of 1912 provision had been made for the surrender of railway revenue to the extent of $£ 1,336,500$ per annum, based on the volume of traffic at the time, and distributed as follows :-

$\begin{array}{lrllllr} & & & & & & \\ \text { Passengers } & \ldots & \ldots & \ldots & \ldots & \ldots & 149,000 \\ \text { Goods and vehicles } & \ldots & \ldots & \ldots & \ldots & 1,076,500 \\ \text { Live stock.. } & \ldots & \ldots & \ldots & \ldots & \ldots & 45,000 \\ \text { Parcels } \ldots & \ldots & \ldots & \ldots & \ldots & \ldots & 16,000 \\ \text { Private sidings charges } \ldots & \ldots & \ldots & \ldots & 50,000 \\ \text { Total } \ldots & \ldots & \ldots & \ldots & \ldots & £ 1,336,500\end{array}$

Besides the general reductions mentioned above, casual reductions in rates were being made continually. ${ }^{15}$

The most striking feature of the results of operation during the period under review was the extraordinary increase in the passenger and parcels receipts year by year since the establishment of the Union, notwithstanding the substantial reductions in fares. 
RAILWAY EARNINGS DURING THE PERIOD From 1910-19l3. ${ }^{16}$

\begin{tabular}{|c|c|c|c|c|c|c|}
\hline & 1910. & 1911. & 1912. & 1913. \\
\hline \multicolumn{2}{|c|}{ Hear of Revenue. } & & $£$ & $\mathfrak{f}$ & $\mathfrak{f}$ & $\mathfrak{E}$ \\
\hline Passengers & $\ldots$ & & $2,812,577$ & $3,078,300$ & $3,308,347$ & $3,377,243$ \\
\hline Parcels & $\ldots$ & $\ldots$ & 288,555 & 316,889 & 338,841 & 361,017 \\
\hline Goods and & Minerals ( & & & & & \\
\hline than Coal) & $\ldots$ & $\ldots$ & $6,463,161$ & $6,150,428$ & $6,130,732$ & $6,044,619$ \\
\hline Coal ... & $\ldots$ & $\ldots$ & $2,017,130$ & $2,014,242$ & $1,969,182$ & $1,890,793$ \\
\hline Live stock & $\ldots$ & $\ldots$ & 384,802 & 388,595 & 388,086 & 379,287 \\
\hline Other Traftio & Receipts & $\ldots$ & 99,370 & 100,022 & 77,793 & 77,653 \\
\hline Miscellaneou & & $\ldots$ & 291,937 & 280,789 & 273,376 & 258,143 \\
\hline ot: & & & & $2,329,265$ & $12,486,35$ &, 755 \\
\hline
\end{tabular}

The passenger receipts for 1913 showed an increase of about 20 per cent. orer those for 1910 , and the parcels receipts were enhanced by about 25 per cent. These increases are to be attributed in considerable measure to greater density of traffic as the result of lower fares. For example, the additional passenger earnings had involved an increase of 26 per cent. in the number of passengertrain miles, as compared with an increase of 17 per cent. in the mileage of open line.

The goods receipts, howerer. were more seriously affected by the reductions and the constant displacement of oversea import trade by that in domestic products, as the new railway authorities had formulated preferential rates on South African produce and manufactures. There was a decline of abont $6 \frac{1}{2}$ per eent. in the earnings on goods and mincral traffic. This decline in revenue was not due to a reduction in the tomnage carried by the railways, but was the result of two factris which were becoming more and more important every year in their effeet on the earnings from goods and minerals, namely, the reduction of rates and the increased proportion of low-rated traffic, i.e. South African products, handled by the railways. ${ }^{17}$

The foregoing table indicates the very slight difference in the total railway earnings of the four respective rears. The revenue was comparatively stationary during the entire period, notwithstanding the fact that by the end of 1913 the mileage of line had been increased by 17 per eent. since the date of Union-8.282 miles as compared with 7.041 miles. $^{18}$ The revenue accruing from the operation of the new lines was virtually balanced by the reduction in the revenue from the existing lines. $\begin{aligned} 16 \text { Q.A. of Tnion Statisties, Oct., } & 17 \text { Report of General Manager for } 1912 . \\ 1920, \mathrm{p} .73 . & \end{aligned}$ 
In 1913 the passenger receipts represented 27.2 per cent. of the total reeeipts, goods and minerals (other than coal) contributing 48.8 per cent. and eoal 16.07 per eent.

While the railway earnings were practically stationary during the four-year period under consideration, the ordinary operating expenditure and renewal eharges were subject to a steady increase, as illustrated by the table following:-

RAILWAY EXPENdTURe ${ }^{19}$ From 1910 To 1913.

$\begin{array}{ccccc}\text { Hearl of Expenditure. } & 1910 . & 1911 . & 1912 . & 1913 . \\ & \mathfrak{L} & \mathfrak{f} & \mathfrak{f} & \mathfrak{L} .\end{array}$

Maintenance of Permanent

Way and Works ...

Maintenance of Rolling Stock

Running Expenses... ...

Traffic Expenses

$\begin{array}{llll}1,222,288 & 1,257,920 & 1,362,233 & 1,433,617 \\ 1,197,710 & 1,310,088 & 1,405,253 & 1,585,922 \\ 1,641,247 & 1,698,590 & 1,796,067 & 2,008,316 \\ 1,378,164 & 1,510,545 & 1,638,932 & 1,791,640\end{array}$

General Charges and Superannuation ... ... ...

$\begin{array}{llll}\text { Cartage } & \ldots & \ldots & \ldots\end{array}$

Total Ordinary Operating Expenditure $\quad . . \quad \ldots$

Relaying, Strengthening, etc. Depreciation :

Permanent Way \& Works Rolling Stock

564.955

426,271

$$
394,817
$$

492.498 199,794 224,496 239,330 $2+1,917$

\begin{tabular}{|c|c|c|c|}
\hline $6,104,158$ & $6.427,910$ & $6,836,632$ & $7,553,916$ \\
\hline- & - & 176.127 & $230,07: 3$ \\
\hline 282,001 & $334,67.5$ & 355,158 & 367,493 \\
\hline$+76,525$ & 678,981 & 744,757 & 813,214 \\
\hline 758,526 & $1,013,656$ & $1,276,042$ & $1,+10,780$ \\
\hline $6,862,681$ & $7,441,566$ & $8,112,674$ & $8,964,690$ \\
\hline
\end{tabular}

Total Renewals

Total Operating Expenditure

The total operating expenditure was subject to an inerease of $\mathbf{2 5 . 6}$ per cent., which compares favourably with an increase of 28 per eent. in the number of passengers carried, 16 per cent. in the tonnage of revenue earning freight, 30.8 per cent. in train and chine mileage, and 17 per cent. in mileage of line. In respect of renewal and depreeiation eharges, a very substantial increase is to be noted, namely, $\mathfrak{6 5 2 , 2 5 4}$ or 86 per eent. This is to be attributed to the fact that the large surpluses during the first three years of the Union enabled the railway administration to make larger contributtions to the renewals fund. In 1913 the total renewal eharges represented slightly more than 11 per cent. of the total receipts and 1.7 per cent. of the total eapital investment.

Thus, the rise in the operating expenditure is aceounted for partly by the inerease in the mileage of line worked, partly by the greater 
density of traffic, and partly by the more liberal provision for depreciation and renewals.

The operating ratio had undergone a considerable inerease during this period. In 1910 it was 55.5 per cent., which is an exceptionally low ratio, but by 1913 it had risen to 72.3 per cent. This great increase in the operating ratio is the result of the reductions in rates and fares which caused the revenue to be practically stationary, whereas the operating expenditure was enhanced by the abovementioned factors. The increase in the operating ratio was not a source of eoncern or anxiety to the railway administration, since it was an inevitable adjunct of the new railway policy.

The financial results of this period of reorganization may be summarised in tabular form in the following manner :--

\begin{tabular}{|c|c|c|c|c|c|c|}
\hline Heading & & & $\begin{array}{c}1910 . \\
£\end{array}$ & $\begin{array}{c}1911 . \\
£\end{array}$ & $\begin{array}{c}1912 . \\
\mathfrak{f}\end{array}$ & $\begin{array}{c}1913 \\
\mathfrak{f}\end{array}$ \\
\hline Net Income ... & $\ldots$ & $\ldots$ & $5,565,905$ & $5,063,302$ & $4,485,564$ & $3,322,556$ \\
\hline Interest & $\ldots$ & $\ldots$ & $2,401,143$ & $2,426,973$ & $2,619,470$ & $2,751,314$ \\
\hline Net Profit & $\ldots$ & $\ldots$ & $£ 3.164,762$ & $2,636,329$ & $1,866,094$ & 571,242 \\
\hline
\end{tabular}

The continuons diminution in the net income is not to be construed as the result of state maladministration, but as the result of a systematic attempt to carry into efiect the cost principle specified in the Union Constitution. In 1910 the net profit was 4.2 per cent., in 19113.10 per cent., in 19122.35 per cent., and in 1913.69 per cent. The areage net profit earned by the Prussian state railways prior to the war was about 3 or $3 \frac{1}{2}$ per cent.

The specific proviso on the Union Constitution that the necessary administrative and financial arrangements for the execution of the new railway policy were to be made within four years from the date of Union was practically complied with by the end of 1913. The net profit of 4.2 per cent. in 1910 had been reduced to a fraction of one per cent. by 1913. The approximate balance of revenues and expenditures had been secured, leaving a net profit large enough to meet the deficit that had become a customary result of harbour administration. The harbours had been associated with the railways under the South Africa Act for purposes of control and administration, and as they represented a losing proposition most of the time, the railways were required to yield a small profit sufficient to cover the harbour deficit. The year 191:3, may therefore be regarded as marking the completion of the readjustment and reorganization.

The results of this period of reorganization serve as an indication of the possibilities of railway atlministration in South Africa in 
normal times under eonditions of maximum exploitation. Taling the financial results of the first two years, 1910 and 1911, when the reduction of fares and rates had not yet diffuserl its effects to any marked extent over the railway aceounts, the South Afriean railways are found to be on a par with the Prussian state railways in respect of financial success ; and the Prussian railways are regarded as the most striking example of successful government ownership of railways.

The ability of the South African railways to carn substantial profits in the absence of eonstitutional restrictions on the earning power of the system has been sufficiently demonstrated in the foregoing pages. In its application to the first four years of Union railway administration, the test of financial suceess prescribes an approximation of revenue and expenditure by the end of the fourth year. Such has been attained within reasonable and safe limits, and therefore the Union railways are deserving of being termed a suceessful state enterprise in respeet of its reorganization. Heneeforth the test of sueeess would be the ability of the railway authorities to retain the approximate balance of earnings and expenses.

2. The War Period (1914-1918).- The outbreak of the European War in 1914 marked the inauguration of a long period of abnormal conditions. oecasioning a serious disturbance in the eost of operation as well as in trade and traffie. The intensity of this disturbance has indeed varied in different countries, but on the whole it has been a world-wide phenomenon, affeeting the railway finances of countries in the remotest eorners of the globe. In an effort to balanee revenues and expenditures. various expedients were devised by railway authorities all over the world aceording to the conditions prevailing in any particular country. The expedients most commonly adopted were the following :-

(a) augmenting the revenues by inereases in rates and fares;

(b) making smaller appropriations for depreciation and renewals in the hope that a speedy cessation of hostilities will restore normal eonditions ; and

(c) reducing train mileage.

At different times all of these expedients were adopted by the railway authorities in South Afriea.

The rise in the cost of operation ean be presented most satisfaetorily in tabular form, henee the table on the following page.

During the period from 1914 to 1918-19 the total operating expenditure was enhaneed by $\mathfrak{E 4}, 042,962$. or 45 per eent., as eompared with an inerease of $12 \frac{1}{2}$ per cent., in open mileage, 4.7 per cent. in train mileage, 2.2 .9 per cent. in the number of passengers carried, 
and 17 per cent. in the tonnage of revenue-earning traffic. It is apparent, therefore, that there has been a considerable net increase in operating expenditure due to a rise in the cost of operation, the increase in expenditure being only partly accounted for by the increase in open mileage and in density of traffic. The rise in the cost of operation during this period may be attributed to the war bonus, the increased cost of Indian and native labour, the rise in the seale of pay of guards, drivers, and cleaners. and the enhanced cost of railway supplies.

The war bonus was an item of comparative insignificance until the latter half of 1918, when the recommendations of the Public Service Commission of Inquiry were put into effect and an elaborate war bonus system was instituted, with retrospective effect as from

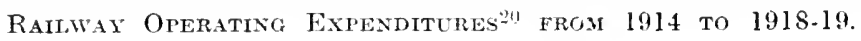

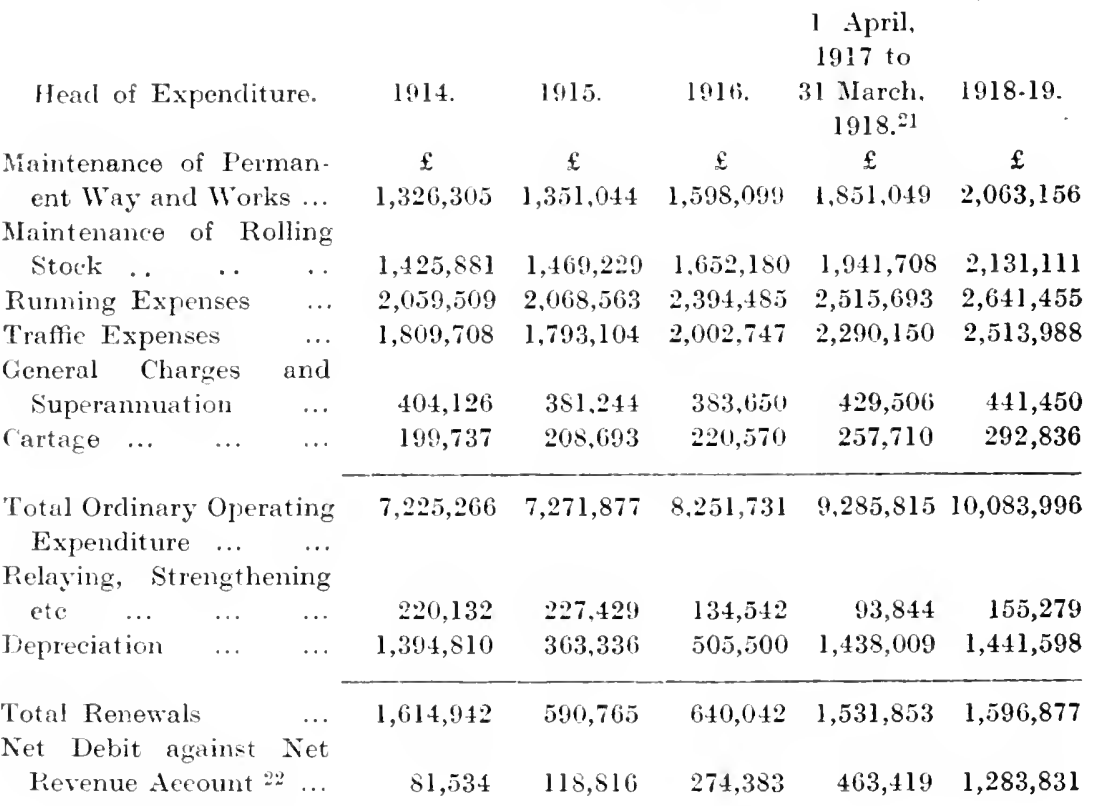

Total Operating Expen-

diture ...

$8,921,742 \quad 7,981,453 \quad 9,166,156 \quad 11,281,087 \quad 12,964,70_{4}$

20 O.Y.B. 1919 , pp. 810.812.

21 The period of 3 months from January 1, 1917. to March 31, 1917, marked the period of transition from the ealendar year to the finaneial year as the basis of the railway aceounting system.

22 This net debit against the net reverue aceount comprises the charges in respect of war bonus, half-pay of employees on active service, lines leased from private companies, and miscellaneous items of expenditure, minus certain miseellaneous reeeipts which are eredited to that account. The table is constructed in this manner on aceount of the lack of detailed statistics. 
I April, 1918. occasioning an additional expenditure of over $£ 1,000,000$. It was decided to regard these temporary allowances as a debit against the net revenue account and not as an clement in the operating expenditure.

The rise in operating cost would have been larger if travelling restrictions had not been introduced and economy in train mileage secured in that way. The railway authorities were obliged to curtail travelling facilities in view of the limited rolling -stock lesonrees at their command and in view of the fact that the means of arlequate replenishment were cut off. It became imperative to reduce train mileage as far as possible, and the adoption of a policy involving the curtailment of the passenger service as well as the entire withdrawal of excursion trains and fares, was reluctantly decided upon. It was estimated that this policy resulted in a saving of 800,000 train miles during $1917 .^{23}$

In respect of depreciation a small appropriation had been made in 1915, as there had been a deficit of $£ 191,000$ at the end of 1914 due to a decline in earnings occasioned by the outbreak of the war and the South African rebellion. However, the tide changed, the railway accounts showing a surphus of $£ 1,310,380$ at the end of 1915 . so that on March 31, 1916, a special appropriation of $£ 958,497$ was made to the Renewal Fund from the profit for the year. ${ }^{24}$ In view of this special appropriation from the profit for the year 1915-16, the ordinary appropriation in respect of renewals for 1916 was likewise.

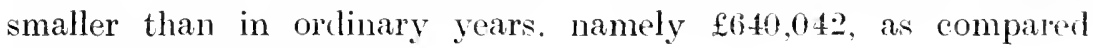
with $£ 1,410,780$ in 1913 .

The reduction in depreciation charges formed a part of the general policy of economy and was resorted to in the hope that a speedy cessation of hostilities would restore normal conditions. By 1917 , however, it was apparent that the war was destined to continue for

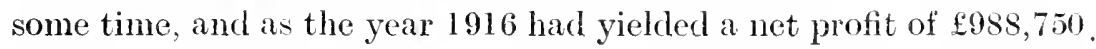
it was deeided to return to normal expenditures on renewals the rates and fares having been increased to yield more revenue.

During the period from $191+$ to $1918-19$ the railway earuings showed an increase of 32 per cent., as compared with an increase of 45 per cent. in the case of the total operating expenditure.

23 Board of Trade Joumal, May 16 , 1918 , p. 619 .

2) O.Y.B. 1918 , p. 659 . 
RaIlway Earnings ${ }^{25}$ From 1914 to 1918.19.

\begin{tabular}{|c|c|c|c|c|c|c|}
\hline \multicolumn{2}{|c|}{ Head of Revenue. } & $\begin{array}{c}1914 . \\
£\end{array}$ & $\begin{array}{c}1915 . \\
£\end{array}$ & $\begin{array}{c}1916 . \\
\mathfrak{E}\end{array}$ & $\begin{array}{c}1917-18 \\
£\end{array}$ & $\begin{array}{c}1918-19 \\
£\end{array}$ \\
\hline Passengers & $\ldots$ & $3,190,366$ & $3,457,086$ & $3,443,323$ & $3,801,928$ & $4,210,159$ \\
\hline \multicolumn{7}{|c|}{ Goods and Minerals (other } \\
\hline than Coal) & $\ldots$ & $5,396,131$ & $5,651,294$ & $5,808,660$ & $5,932,736$ & $6,517,038$ \\
\hline Coal & $\ldots$ & $1,842,809$ & $1,776,100$ & $2,815,244$ & $3,152,412$ & $3,083,204$ \\
\hline Live Stock & $\ldots$ & 448,995 & 596,983 & 466,683 & 524,921 & 520,315 \\
\hline Parcels ... & $\ldots$ & 362,900 & 352,322 & 338,479 & 369,838 & 397,235 \\
\hline Other Traffic $\mathrm{R}$ & eceipts ... & 77,868 & 79,479 & 77,935 & 80,477 & 80,548 \\
\hline Miseellaneous & Receipts & 254,135 & 284,626 & 306,743 & 453,548 & 473,780 \\
\hline
\end{tabular}

Total

$11,573,20+12,197,890 \quad 13,257,067 \quad 14,315,860 \quad 15,282,279$

The year 1914 shows a decline in earnings of $£ 815,551$ in comparison with 1913, as a result of the disturbance in trade and traffic caused by the ontbreak of the European War and of the South African Rebellion. Even the earnings for 1915 were $£ 190,865$ less than those for 1913. In 1916, however, the earnings were increased by more than $£ 1,000,000$ over those for 1915 . This increase was mainly due to the enhanced receipts in respect of the coal traffic, in consequence of the increased demand for bunker coal and the imposition of a special sureharge of 6 s. per ton on all coal used for bunkering purposes. In 1917-18 the coal receipts were still further enhanced by an additional surcharge of $4 \mathrm{~s}$. per ton of bunker coal, thus making the total special surcharge on bunker coal 10s. per ton. This surcharge was imposed in view of the fact that an increase in the bunker coal rates was the means of securing additional revenue that would least affect the South African producer and consumer.

In May, 1918, the financial position necessitated further increases, and this was the first occasion on which the rates on internal traffic were advanced. A sureharge of $2 \frac{1}{2}$ per cent. was added to ordinary passenger fares and 5 per cent. to season tickets, and in addition a general terminal charge was levied, varying from $6 \mathrm{~d}$. to $2 \mathrm{~s}$. 6d. per ton according to the class of traffic. On account of the reduction in the bunkering trade and the diversion of shipping to the northern hemisphere during the latter stages of the war, as also of the greatly enhanced cost of living and of materials after the Armistice, it was necessary to make a further increase in January, 1919, in the form of a surcharge of 10 per cent on goods, live stock, and parcels lates. At the same time, the opportunity was utilized to revise the passenger fares and adjust anomalies inherited from pre-Union days. 
The increase of 32 per cent. in railway earnings during the period from 1914 to 1918-19 was only to a small extent the result of inereased rates and fares. The main contributing factor was the substantial inerease in traffie, both passenger and freight; namely, an inerease of 22.9 per cent. in the number of passengers earried, 21.5 per eent. in the tomnage of goods traffie, and 14 per eent in the tonnage of coal traffie.

The increase of traffie was the result of a marked expansion of internal and interprovineial trade, due chiefly to the growth of agricultural produetion and the establishment of new industries. It was a remarkable feature that a heavy deeline in imported traffie had been eounterbalanced by a contemporaneous increase in internal traffie. 'The restrietion of imports in eonsequence of limited shipping aecommodation afforded a substantial stimulus to domestic produetion. The elass of traffic earried over the railways had thus undergone a change. In 1911 low-rated traffie constituted 84 per cent. of the total, whereas in May, 1919, the percentages were 92 per cent. for the low-rated traffie and $s$ per cent for the high-rated traffie. ${ }^{26}$ This had the effeet of depreeiating rates and reducing the revenue for the same volume of traffie handled, thereby altering the relationship of revenue earned to work performed. The inerease in rates in respect of goods and mineral traffie was eounterbalanced by the increase in the proportion of low-rated traffie, the average earnings per ton of goods earried in 1918-19 being even slightly less than in 1914.

Summary of Financial Results of War Period.-The following table $^{27}$ shows the net profit or loss in respect of the operation of the railways during the period from 1914 to 1918-19:-

\begin{tabular}{|c|c|c|c|c|c|c|}
\hline \multirow{3}{*}{ leading } & & \multicolumn{5}{|c|}{$\begin{array}{l}1 \mathrm{Jan} \text {. } \\
1917 \text { to }\end{array}$} \\
\hline & 1914. & 1915. & 1916. & $\begin{array}{l}31 \text { March, } \\
1917 .\end{array}$ & 1917.18 & 1918.19 \\
\hline & $\mathfrak{f}$ & $f$ & $\mathfrak{E}$ & $£$ & $\mathfrak{f}$ & $\mathfrak{E}$ \\
\hline Net Income & $2,651,462$ & $4,216,432$ & $4,090,911$ & $1,133,549$ & $3,034,773$ & $2,317,575$ \\
\hline Interest & $2,842,486$ & $2,919,552$ & $3,102,162$ & 778,669 & $3,216,525$ & $3,213,842$ \\
\hline
\end{tabular}

Net Profit or

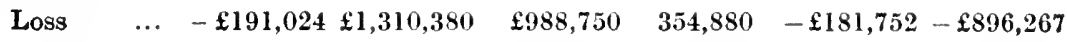

Taking into eonsideration the fact that the large profit for 1915 was due to the small depreeiation and renewal charges provided for in that year and that a special appropriation of $£ 958,497$ was made

\footnotetext{
26 Report of General Manager for 27 O.Y.B. 1919, pp. 809 and 812. 1919-20.
} 
in 1916 to the Renewal Fund from the profit, which renders it necessary to dednet that sum from the profit of $£ 1,310,380$ for 1915 in an effort to secure a comparable basis, the financial result of the operation of the Union railways during the perjod from 1914 to $1918-19$ proves to be a small net profit of $\$ 426,470$.

Under normal eonditions the test of financial sueeess, in its application to the South African Railways, prescribes an approximate balanee of earnings and expenditures and comparative uniformity in rates and fares over a period of years. In respect of the War period, howerer, the test of financial suceess needs to be modifier, in view of the abnormal conditions, and is to be interpreted as preseribing merely an approximate balance of revenues and expenditures and requiring that increases in rates and fares be not excessive.

With regard to the period under review both of these conditions have been fulfilled. In adding up the profits on the one side and the losses on the other, realised over a period of more than five years, the result of the calculation is a small balance of $£ 4: 26,470$ in favour of profits. In the matter of rates and fares the increases were slight in comparison with those prevailing in other countries at the time. At the end of the war period the increases in operation in South Africa eomsisted merely of :-- 1 ) a general advance of 10 per cent. in passenger fares and freight rates, and (2) a speeial surcharge of $10 \mathrm{~s}$. per ton on all coal to be used for bunkering purposes. These inereases in rates and fares were smaller than almost anywhere else in the world at the time. Thus the conclusion may be justifiably drawn that, not only in respect of the period of reorganization, but also in respect of the war period. the South African railways have proved to be deserving of being termed a suceessful state enterprise.

3. The Alteimath.--Expcetation that the termination of the war wonld be followed hy a general and rapid improvement in transportation conditions were not fulfilled. The war period had its own speeial dificulties, but the post-War period had given rise to others no less perplexing. Throughout the greater part of the world there has been eonstant industrial and soeial unrest - the aftermath of the war. This unrest was felt in South Africa in a lesser degree than in other parts of the world, but the Union had its own problems, as it was still dependent upon oversea countries for many vital necessities and the delay in obtaining these requisites retarded the industrial development as well as the equipment of the railways to cope with the increasing traffie demands.

The magnitude of the railway development during the first decade of the Union ean be most strikingly illustrated by means of a com- 
parison with the collective figures for the colonial systems in 1909 , the year prior to the Union :-

Open Mileage

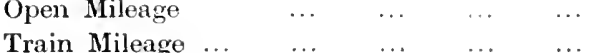

$\begin{array}{cc}\text { Increase. } & \text { Percentage. } \\ 2,650 \text { miles. } & 39 \\ 13,913,000 \text { miles. } & 71 \\ £ 23,342,000 & 32 \\ 32,541,000 & 116 \\ 3,346,000 \text { tons. } & 90 \\ 2,516,000 \text { tons. } & 49\end{array}$

The following table shows the gross revenues and expenditures, anel the cleficits, for the rears $1919-20$ and $1920-21$ :-

\begin{tabular}{|c|c|c|c|c|c|c|}
\hline & Headi & $\operatorname{ming}$. & & & $1919-20$ & 1920.21 \\
\hline & & & & & $\mathfrak{E}$ & $\mathfrak{t}$ \\
\hline Gross & Expenditure & $\ldots$ & $\ldots$ & $\ldots$ & $20,284,131$ & $25,366,597$ \\
\hline Gross & Revenue & $\ldots$ & $\ldots$ & $\ldots$ & $19,575,709$ & $23,945,145$ \\
\hline & Defici & & $\ldots$ & $\ldots$ & $\mathfrak{f 7 0 8 , 4 2 0}$ & $£ 1,421,452$ \\
\hline
\end{tabular}

The expenditure for $1919-20$ exceeded that for $1918-19$ by $£ 3,571,152$, or 21 per cent., and in $1920-21$ the expenditure was enhanced by a further 25 per cent., due to increased rates of pay, additions to the cost of living allowances, the extension of the eight-hour day. and the enormously enhanced cost of railway supplies.

With a view to meeting this extraordinary increase in the expenditure the railway authorities were obliged to resort to further increases in rates and fares. In November, 1919, the surcharge on goods, parcels, and live stock traffic was increased from 10 to 25 per cent., and a io per cent. surcharge was imposed on passenger fares. In April, 1920, the former surcharge was increased from 25 per cent. to $33 \frac{1}{3}$ per cent., while that on yassenger fares was increased from one-tenth to one-sixth. At the same time a consolidated increase of 20s. per ton over pre-war rates was introduced in respect of bunker coal, and a consolidated net increase of $2 \mathrm{~s}$. 2d. per ton on export coal. In July, 1920. the surcharge on bumker coal of $20 \mathrm{~s}$. was increased to $30 \mathrm{~s}$. per ton, and the rates for export cargo coal were increased by $10 \mathrm{~s}$. per ton, and that for coal for bunkering ships taking full cargoes of export coal was increased by כas. per ton. In October, 1920, a general revision of the rates and fares was introduced, the main objects being to secure additional revenue and to place the tariffs on a basis adapted to the altered agricultural and industrial conditions of the Union and conducive to its economic development. Estimates show that at the end of 1920 the average

28 Q.A. of Union Statisties, July 1921, p. 69. 
increase for all kinds of traffic was approximately 58 per cent. above pre-war rates. If the increases on bunker and export eoal are excluded, on the grounds that they did not to any appreciable extent affect the people of South Africa, the average inerease on the remaining traffic was approximately 42 per cent.

The year 19:0-21 proved to be a year of severe trial for the railway management. In view of the defieit of $£ 708,422$ resulting from the operation of the railways during 1919-20, the management had reluctantly deeided to make a further advance in rates and fares. It was estimated that this increase would rield additional revenue to the extent of $£ 816,000$, and a small surplus was expeeted to result. However, urgent lemands were made by the railway officials and employees for a further increase in salaries and wages on account of the rise in the eost of living during the first half of 1920 . These demands were granted and involved an additional expenditure of about $£ 800,000$. This necessitated a further inerease in rates and fares, which was estimated to yield about $£ 1,000,000$ in revenue. Once more the railway authorities reckoned on a surplus at the end of the year. only to be clisappointed again and confronted with new obstacles. This time it was the falling off in the traffic, both passenger and freight. The reduction in imports alone involved a loss of about $£ 900,000$ in railway earmings. T'he depression in trade and commerce was acute and necessitated the general revision of rates referred to above. However, the final result was a deficit of

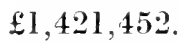

With regard to the year 1921-22 the poliey of the railway authorities is to diminish the operating expenditure rather than to increase the rates and fares, which, it is realised, have now reached the stage where any further increase would yield praetically no increase in revenue. The estimated expenditures for 1921-22 are less than the actual expenditures of $1920-21$ by about $£ 1,500,000$. In respect of certain items of expenditure economies will be effeeted to the extent of $£ 2,500,000$, of which the most important are :$£ 1.724,000$ on account of the gradual elimination of the war bonus, and $£ 498,000$ in respeet of train mileage; but in other ways the expenditure will be enhaneed by about $£ 1,000,000 .^{29}$

On the other hand, the estimated revenues for 1921-22 are less than the actual revenues for $1920-21$ by about $£ 940,000$. This is to be attributed to the reduction in the rates on bunker and export coal with a view to retaining the coal trade, which was endangered by foreign eompetition, and to the renewed decline in passenger and 
goods traffic. If the year 19:1-2:2 witnesses a sudden revival of trade and prosperity, a surplus may be earned, otherwise another deficit will arise. The estimated deficit on account of the railways is $£ 792,622$.

The deficits have been carried to the revenue distribution aecount and are to be paid for by future profits. This implies that for a series of years the railways will be operated with a view to earning a profit in order to liquidate the deficits that have accumulated as a result of abnormal conditions. When that object has been attained. the railways will return to the cost prineiple and merely aim to pay expenses. It must be borne in mind, however, that the railway deficits are somewhat diminished by the net surpluses earned by the harbours and steamships, which are united with the railways under one management, the three being treated as one enterprise from the point of view of administration. For example, in 1920-21 the operation of the railways resulted in a deficit of $£ 1,421,452$, whereas the harbours and steamships yielded a joint surplus of $£ 371,761$, leaving $£ 1,049,691$ as the net deficit incurred by the Railway and Harbour Administration.

The years following the war period have thus proved to be beset with greater difficulties than the five years of the war period itself. Whereas the railways were found to have been successful during the first eight years of the first decarle of the Union, they have become a losing proposition cluring the last three years. This retrogression, however, is the result, not of mismanagement or change in management or political interference, but of a series of abnormal conditions which have been refleeted in railway administration in every country in the world. Railway deficits have become proverbial, and railway rates have been advanced in some countries to 200 and 300 per cent. above pre-war level. On making a comparison between the rates and fares prevailing in Sonth Africa at the beginning of 1921 and those prevailing in other countries at the same time, it appeared that South Africa was one of the countries that had experienced the smallest increases in rates and fares. In the light of such a comparison and in view of the facts that the deficits, taken altogether, hardly amount to the net profit of 1910 , the first year of the Union, the conclusion may be drawn that the South African railways have been able to comply with the test of financial success within reasonable limits.

In view of the cost principle serving as the basis of the railway system and the requirement that all railway carnings are to be applied for railway purposes only, except in the case of deficits in the har- 
bour aceounts, the railways appear to be of no fiseal signifieance. During the first three years of the Union, when they were partially operated on the profit principle and yielded large surpluses, the sum of $£: 3,179,000$ was paid over to the Union Treasury, namely, f1.5:0,000 in $1910-11, £ 1.159,000$ in $1911-12$ and $£ 500,000$ in 1912 . $1: 33^{3 \prime}$ However, after the completion of the readjustment in 1913, any surplus earned was to be paid into the equalization fund; so that the railways are practically isolated from the fiscal system of the Union.

On the other hand, interest is paid to the Treasury by the Railway and Harbour Administration on a sum of $£ 13,138,263$ (in 1920) which represents railway capital raised from general revenue by the Colonies prior to the establishment of the Union; so that the Treasury receives annually from the railways and harbours an amount of. about $\$ 450.000$ which may be classified as an item of commercial revenuc. Since 1913 this is the sole revenue aecruing to the Union Treasury from the railways and harbours, and as such it is not of the nature of a profit earned by those enterprises but is really interest on the investment of the surplus re renues of the eonstituent Colonies. 


\section{('HAP'TER:-}

Harbours, Stendiships, Post Office, Thlegrapis ind 'TelePHONES, LAND BANK.

(1) Harbours.

The harbours, ports, and lighthouses of the Union of South Africa are owned and managed by the Union Government. They are associated under the South Afriea Act with the railways of the Union for the purposes of control and administration, and financially are upon the same footing as the railways in accordance with the provisions of the constitution dealing with the Railway and Harbour Fund. The management and operation of the railways and harbours are. subject to the control of the Minister of Railways and Harbours, vested in the General Manager of Railways and Harbours. who is governed by such regulations as the Minister may from time to time frame after consultation with the Railway and Harbour Board.' These are the sole enterprises of the Union Government which are conducted in accordance with eommercial prineiples, and in respect of which a separate budget is submitted to Parliament; and from the administrative point of view they are to be regarded as one enterprise.

There is only one aspect of administration with regard to which provision was made in the case of harbours and not in the case of railways, namely, the institution of advisory boards. Each advisory board consists of seven members, one member to be nominated by the Municipal Council of the town at which the harbour is situated, three by the Chamber of Commcree of such town. and the remaining three mombers by the Governor-General. In the nomination of the last mentioned three members, one is selected with a view to representation of the shipping interest, and one to the representation of the persons paying wharfage or landing, shipping, or transhipping dues at the harbour. ' The main function of these boards is to advise the Administration upon any matter affecting the interest or welfare of the respective harbours: the construction. maintenance,

1 Act 17 of 1916 , sec. 2 .

act 22 of 19I6. sec. 11 (1). 
and upkeep of harbour works ; the landing, shipping, and transhipping of cargo; the charges upon goods and upon shipping, etc. By the institution of the advisory boards provision has been made for responsiveness to public opinion to the extent indicated above.

Capital Expenditure.-The total capital expenditure incurred in connection with the harbours of the two coastal provinces of the Union, the Cape of Good Hope and Natal, amounted to $£ 10,259,180^{3}$ on March 31, 1919. At the establishment of the Union in 1910, the sum of $£ 11,399,523^{4}$ had been expended on capital account in respect of the harbours of the two coastal colonies, but in September, 1916 , assets to the value of about $£ 2,000,000$ were transferred from the Harbour Capital Account to the Rajlway Capital Account. During the period from 1910 to 1919 the new capital expenditure on harbours incurred by the Union Government amounted merely to about $£ 1,000,000$, the colonial governments having attended to the main clevelopment.

Financial Results.-In the case of the harbours, as with the railways, the Union Constitution prescribed the adoption of business methods in the managenent and operation thereof, and of the cost prineiple as the basis of the financial policy; but whereas the colonial railways had yielded substantial profits which were to be disposed of by reductions in rates and fares, the harbours had yielded deficits from year to year.

Assuming as the basis of sound judgment the axiom that the suecess of a public industry depends on the degree in which the financial results aceord with the prescribed policy, the South African harbours may be regarded as a successful government enterprise if over a period of ten years an approximate balance of revenues and expenditures has been attained. In view of the fact, however, that the first decade of the Union is not suitable for the application of this test of suceess on account of the reorganization during the first five years and the abnormal war conditions of the latter half, a modification of the test is required, which is to be interpreted as implying the attainment of the approximate equalization of revenue and expenditure within a reasonable period after the establishment of the Union and the maintenance of the equalization for the remainder of the decade.

Revenue.-The following table ${ }^{5}$ shows the earnings of the Union harbours over a period of years and the yield of the various dues and eharges that are levied.

3 O.Y.B. 1919 , p. 769.

4 S.Y.B. $1914 \cdot 15$, p. 183.
5 O.Y.B. 1918, p. 619 , and O.Y.B. 1919 , p. 770 . 
Head of Revenue.

Dues on Ships ...

Dues on Goods and Live

Stock ... ...

Charges for Water ...

Charges for Tugs and

Lighters $\quad \ldots \quad \ldots$

Landing, Shipping and

Transhipping Charges

Charges for:

Cranage Services ...

Dry Dock and Ships ....

Coaling Operations ...

Rents and Miscellaneous

Revenuo

Total ...
$1912 . \quad 1914$.

$\mathfrak{E}$

104,206

280,056

15,836

47,328

355,251

30,050

18,750

42,449

$£$

120,531

1916.

1917-18.

1918.19.

$\mathfrak{E}$

136,364

$\mathfrak{E}$

$141,24.5$

$\mathfrak{E}$

103,759

244,572

363,253

475,360

$58: 3,133$

20,005

19,815

25,284

13,952

44,281

74,114

92,381

76,339

398,391

282,741

$5.32 !$

3,175

\section{0,982}

34,151

46,717

43,739

10,346

17.066

40,210

29,416

47,618

46,258

57,085

$53,113 \quad 64,061 \quad 56,470 \quad 53,994 \quad 28,742$

$£ 947,039 \quad £ 976,331 \quad £ 1,031,592 \quad £ 926,778 \quad £ 939,340$

In view of the recurring deficits in respect of the administration of the harbours, the dock. harbour, and port dues were inereased by 25 per ecnt. in June, 1916. As from September 1, 1916, a completely revised tarifi of harbour dues and charges at the principal ports of the Union was instituted, with a view to ensuring that the harbours collectively, as apart from the railways, shall be self-supporting. and to reconciling as far as practicable the port and harbour charges in such manner as to render them equally fair in their incidence to the coastal and the inland consum(r." As a result of these and subsequent changes. the dues on goods and live stoek yielded a considerable increase in revenue from 1916 onwards.

The year 1916 witnessed a further important adjustment in regard to harbour finance. The earnings and expenses in connection with shore work at the harbours, which were previously included in the harbour accounts, were included in the railway accounts as from September 1, 1916. This resulted in a substantial reduction in harbour revenue from landing, shipping, and transhipping charges in 1916, and in its virtual disappearanee, from 191718. Thus, in spite of the increase in the charges and dues, the harbour revenue for the finaneial year 1918-19 was even slightly less than the revenue for the year 1912, on account of the transfer of certain harbour revenues to the railway aecount.

Expenditure.-The following table ' ${ }^{\top}$ shows the amount and character of the operating expenditure on the harbours :1916.

6 Board of Trade Journal, Sept. 28,

? O.Y.B. 1918, p. 619, and O.S.B. 1919. P. 770. 
Head of Expenditure.

Maintenance and Upkeep

Trafhe Working ...

General Charges, etc. ...

Total Ordinary Working

Expenditure ... ...

Depreciation

Total Operating Expendi-

ture

\begin{tabular}{ccccc}
1912. & 1914. & 1916. & $1917-18$. & $1918-19$. \\
$\mathfrak{f}$ & $\mathfrak{f}$ & $\mathfrak{f}$ & \multicolumn{1}{c}{$\mathfrak{f}$} & \multicolumn{1}{c}{} \\
269,382 & 296,614 & 305,604 & 298,396 & 319,013 \\
266,818 & 322,440 & 249,275 & 39,882 & 37,895 \\
56,938 & 52,458 & 44,660 & 31,818 & 37,063
\end{tabular}

$\begin{array}{rrrrr}593,138 & 671,512 & 599,539 & 370,096 & 393,971 \\ 215,383 & 184,735 & 57,000 & 86,849 & 85,895\end{array}$

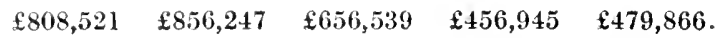

The operating expenditure in respect of harbours was subject to a considerable deerease in 1916, and to a still further decline in $1917-18$, in eonsequenee of $(a)$ the transfer of expenses in connection with the shore work at the harbours to the railway aceounts, and $(b)$ the reduction in depreciation eharges as a war emergeney measure. A portion of the reduction in depreciation is to be attributed to the transfer of certain assets, to the amount of $£ 2,000,000$, from harbours to railways during 1916 , the depreciation charge in respect of such assets being subsequently provided for in the railway appropriations ; but the major part of the reduetion was due to the eeonomy neeessitated by the war.

The interest charge in conneetion with the administration of harbours in South Afriea, where the construction was rendered an expensive undertaking by such physieal obstacles as sand-bars, constitutes a comparatirely high proportion of the total expenditure. In 1912 the interest on the eapital expenditure represented 32 per eent. of the total current expenditures, and in 1918-19 about 40 per eent., the higher percentage in the latter year being due to the large reduction in the operating expenditure.

The harbours also represent an enterprise in which the staff is relatively small. On Mareh 31, 1918, the regular staff comprised 1,461 members-780 white and 681 coloured employees, and in addition there were 799 casual employees, making up a total of $2,260{ }^{8}$

Summary of Financial Operations.-The financial results of the South African harbours may be summarised in tabular form as follows:--. 9 


\begin{tabular}{|c|c|c|c|c|c|c|}
\hline Heading. & $\begin{array}{l}1911.12 . \\
\mathfrak{f}\end{array}$ & $\begin{array}{c}1913.14 . \\
£\end{array}$ & $\begin{array}{l}1915 \cdot 16 . \\
£\end{array}$ & $\begin{array}{l}1917 \cdot 18 . \\
\mathfrak{E}\end{array}$ & $\begin{array}{l}1918 \cdot 19 \\
\mathfrak{E}\end{array}$ & $\begin{array}{l}1919-20 \\
£\end{array}$ \\
\hline Gross Revenue & 869,427 & $1,043,615$ & 999,958 & 928,091 & 940,285 & $1,010,265$ \\
\hline \multicolumn{7}{|l|}{ Gross Expen- } \\
\hline deture & $1,107,273$ & $1,289,826$ & $1,083,907$ & 822,604 & 883,205 & 993,071 \\
\hline $\begin{array}{cc}\text { urplus or } \\
\text { Deficit } \quad \ldots\end{array}$ & 237,846 & 246,211 & $-\mathfrak{E} 83,949$ & f105, 487 & $\mathfrak{£ 5 7 , 0 8 0}$ & $£ 17,1$ \\
\hline
\end{tabular}

The adjustment of harbour finance so as to eomply with the provisions of the Union Constitution, namely, that the harbours are to be managed in accordanee with business principles and that the earnings are to be suficient to pay expenses, was effected in 1916. During the first five years of the Union the harbours had yielded an annual deficit of substantial amount. In the latter half of the decade, however, there was an annual surplus, which tended to diminish with the rise in the cost of operation.

This adjustment was brought about as the result of three factors: - $(a)$ the revision of the harbour tariffs, embodying an increase in the dues and charges; (b) the transfer of certain functions to the railways, namely, the work of landing, shipping, and transhipping eargoes; and $(c)$ the reduction of depreciation charges in order to partially offset the increased cost of operation occasioned by the war.

Thus, the harbours proved to be a self-supporting enterprise of the Union Government during the second half of the decade under consideration.

In 1920-21 a net surplus of $£ 318,156^{111}$ was attained, which might be attributed in the main to the large inerease in shipping and in the total tonnage handled at South African ports, due to the return to their regular trade routes of ressels which had been employed in other spheres during the war. For the year 1921-22 a net surplus of about $£ 50,000^{11}$ was estimated by the Minister of Railways and Harbours, the sharp decrease resulting from the anticipated contraetion of shipping activities.

The harbours have been transformed from a losing to a self-supporting enterprise, and there is every reason to expect that normal times will confirm this transformation.

(2) Steamships.--In 1919 the Union Government acquired several steamships of German origin by virtue of its participation in the War. These steamships were placed under the control of the Railway and Harbour Administration, to be operated in aecordance with the principles and regulations governing the railways and harbours.

\footnotetext{
10 Quarterly Abstract of Union Statis- 11 Budget Speech, April 1921. tics, July 1921 , p. 69.
} 
In view of the fact that the railways have been operated at a deficit in recent years, the steamships were to yield as large a surplus as possible under the cireumstances, and as a result of the great demand for shipping in South African waters in 1919 and 1920, they were able to produce a relatively large surplus, as inclicated in the following table. ${ }^{12}$

\begin{tabular}{|c|c|c|c|c|}
\hline Heading ... & $\ldots$ & $\begin{array}{c}1919-20 . \\
\mathfrak{f}\end{array}$ & $\begin{array}{c}1920.21 \\
\mathfrak{f}\end{array}$ & $\begin{array}{l}\text { 1921-22. (Estimates) } \\
\mathfrak{f}\end{array}$ \\
\hline Gross Revenue & $\ldots$ & 268,903 & 351,943 & 292,482 \\
\hline (iross Expenditure & $\ldots$ & 176,573 & 298,337 & 256,233 \\
\hline Set Surplus & $\ldots$ & $f 92,330$ & 403,1606 & $£ 36,2+9$ \\
\hline
\end{tabular}

(3) P'ost Office, T'elegruphs, and Telephones.

The Inion Department of Posts and Telegraphs was created on the 31st Hay, 1910, when the Union was constituted. The administration and control of the Department is, subject to the authority of the Minister of Posts and Telegraphs, vested in the Postmaster-General, who is entrusted with the supervision and control of all persons in the service of the Department, and all post offices, and postal, telegraph. and telephone services. ${ }^{13}$

The Department of Posts and Telegraphs is not conducted in accordance with commercial principles, as in the ease of the railways and harbours. In the first place, no direct provision is made for a complete capital account. The eapital investment in respect of the postal, telegraph, and telephone services of the Union does not permit of very accurate computation. since the capital expenditure of the post office, and to a certain extent of the telegraphs and trephones, is included under the head of " public works and buildings," in which case a considerable proportion of the expenditure is defrayed from revenue.

With regard to telegraphs, a capital expenditure of $£ 1,077,189$ was iccorded at the establishment of the Union in 1910. By the (nd of 1920 it had advanced to $\$ 1,298,951$, which is an increase of conly 20 per cent., whereas in the case of the telephones there was an increase of 213 per cent.-from $\mathfrak{E} 83,239$ in 1910 to $£ 2,797,011$ in 1920. ${ }^{11}$ This capital expenditure relates to telegraph and telephone apparatus, fixtures, materiaks, etc., and does not include building aecomodation.

\footnotetext{
12 Quarterly Abstract of Union Statis. tics, July 1921, p. 69.

13 Act 10 of 1911 , s.e. 3.
}

14 S.Y.B. $1914 \cdot 15$, pp. 186 and 189 and Quarterly Abstract of Union Statisics, July 1921, p. 70. 
Secondly, as a corollary of the lack of a complete capital account, no provision is made for the payment of interest on the eapital investment from the postal, telegraph, and telephone revenues; not even in the case of the capital expenditure recorded under the separate head of "telegraphs and telephones" in the appropriations from loan funds. The gross receipts are paid into the Consolidated Revenue Fund and the operating expenditure paid out of that fund ; and the interest on the capital expenditure incurred in connection with the Department of Posts and Telegraphs is included under the head of "interest on publie debt" which is paid out of general revenue.

Thirdly, no provision is made for depreciation or even the maintenance of the buildings, the latter function being performed by the Department of Publie Works.

Thus, in contrast to the railways and harbours, the post office, with its allied institutions, the telegraphs and telephones, is not conducted in aceordance with business practices; it is not provided with a separate budgetary system, and as a result its finances are subject to the anthority of the Treasury: and it is not an independent organization but an ordinary government department. and as snch it is liable to politieal interference.

The Department of Posts and Telegraphs is generally represented as a self-supporting department, but upon investigation it proves to be self-supporting in a very limited sense only. The aim of the department is to pay expenses, but such are not taken to inelude interest on the borrowed eapital invested in the gigantie enterprise, or depreciation or even the maintenance of the buildings. The poliey of the Postmaster-General of the Union may be briefly charaeterised as follows:- to furnish the publie with all the modern facilities of communication at a reasonable rate with a view to promoting the general development of the country, and to maintain sueh facilities without imposing an excessive burden on the taxpayer.

In a sparsely-populated country of vast extent such as the Union of South Africa, the means of communication offer no prospects for making a profit and little, if any, for paying total expenses ; and under such conditions and circumstances the government alone is capable of furnishing and maintaining a nation-wide system of post offices, telephones and telegraphs. At the same time, the educational aspects of the postal service and the inestimable commereial advantages of the telegraph and telephone services are so signifieant that moderate charges are demanded even if such oeeasion a nett loss to the Treasury. 
Analysis of Expenditure.-An analysis of the current expenditures in respect of the post office, telegraphs, and telephones, considered as a joint activity of the Union Government, will suffice to indicate the interpretation of the cost principle in the accounts of that department ${ }^{15}:-$

\begin{tabular}{|c|c|c|c|c|c|}
\hline Head of Expenditure & $\begin{array}{c}1911-12 . \\
f\end{array}$ & $\begin{array}{c}1913-14 . \\
\mathfrak{f}\end{array}$ & $\begin{array}{c}1915-16 . \\
£\end{array}$ & $\begin{array}{l}1917-18 . \\
£\end{array}$ & $\begin{array}{c}1919 \cdot 20 . \\
£\end{array}$ \\
\hline Salaries and Wages & $1,02.5,738$ & $1,178,58: 2$ & $1,205,243$ & $1,354,847$ & $1,865,788$ \\
\hline Conveyance of Mails & 348.430 & 334,624 & 324,100 & 323,384 & 334,8 \\
\hline $\begin{array}{l}\text { Maintenance of Tele- } \\
\text { graphs and Telephones }\end{array}$ & 45,195 & 47,622 & $4 \pi, 728$ & 49,250 & 63,4 \\
\hline Miscellaneous ... & 71,841 & 97,269 & 78,634 & 93.647 & 123,230 \\
\hline
\end{tabular}

The expenditures on salarics and wages constitute the great bulk of the total expenditures of the department, the percentage rising from 68.8 in 1911-12 to 78.1 in 1919-20, in view of the large increase in such expenditures as the result of the introduction of the cxtensice war bonus in $191 \mathrm{~s}$ and the general rise in salaries and wages authorised in 1919. During the eight year period from 1911-12 to 1919-20 the expenditures on salaries and wages were enhanced by 82 per cent.. of which only a small proportion is to be attributed to the extension of the staff and of the departmental activities, the main contributing factors being the war bonus and the increased pay. The staff has been extended from 7,656 in 1911-12 to $9.650^{16}$ in 1919-20, an increase of 26 per cent. which therefore accounts merely for about one-third of the increase in the expenditure.

With regard to the conveyance of mails the expenditure has been comparatively stationary. In 1919-20 the sum of $£ \$ 1,844$ was paid to the South African Railways for the conveyance of mails, and ako an amount of $\{3,311$ to the New Cape Central Railways (a private sytem) for mails carried orer that line. ${ }^{17}$ The net amount payable by the Union of South Africa to the Union Castle Steamship Company for the conreyance of mails overseas between Cape Town and Southampton was $£ 26.634$ out of the total subsidy of f1.50.000. the remainder being asigned to Great Britain and the other contracting parties. Post-cart service contracts for the transportation of mails from the railway station to the post office, and

\begin{tabular}{|c|c|}
\hline $\begin{array}{l}15 \text { O.Y.13. } 1918, \text { p. } 1997 \text { O.Y.B. } 1919 . \\
\text { p. 854. and Alpropriation Arenunts } \\
1919.20 .\end{array}$ & $\begin{array}{l}16 \text { Report of Auditor-General for } \\
1919-20 . \text { P. } 308 \text {. } \\
17 \text { Ibid, p. } 310 .\end{array}$ \\
\hline
\end{tabular}


from the post office to the railway station, account for the remainder of the expenditure on the conveyance of mails.

Analysis of Rerenue.-An analysis of the so-called "Union Postal Revenue " will serve to inclicate the relative significance, from the point of view of finance, of the postal, telegraph, and telephone services of the Union.

\section{Post Office Revenue. ${ }^{18}$}

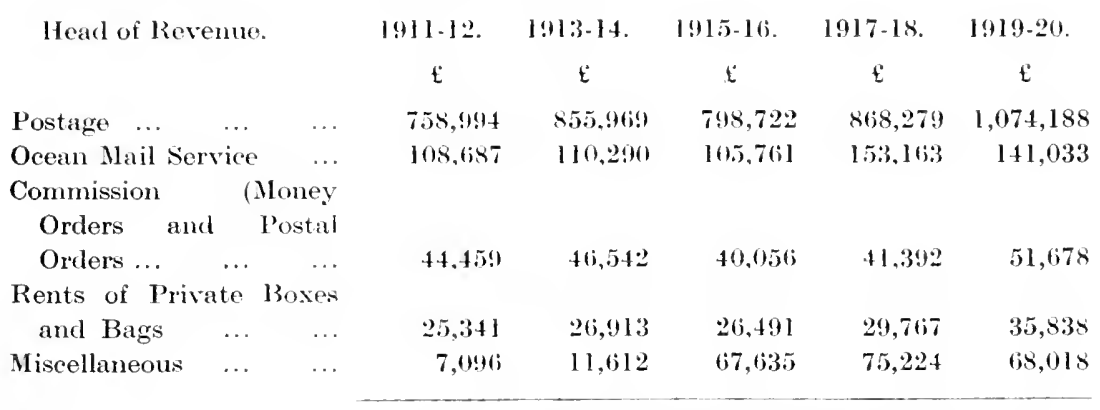

Total Post Office Revenue

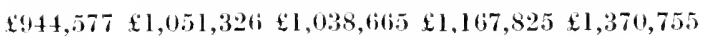

The postage receipts constitute the great bulk of the post office revenue, generally about 80 per cent. During the eight-year period from 1911-12 to 1919-20 the revenue from postage was enhanced by 41 per cent., which is partly accomted for by the extension of postal facilities, the number of post offices having been increased by 25 per cent., and partly by the general expansion of business during the latter stages of the war and the period immediately following the conclusion of the war.

The revenue from ocean mail service represents the contributions by Great Britain, Southern Rhodesia, and the Bechumaland Protectorate towards the payment of the subsidy to the Union Castle Steamship Company in terms of the mail contract entered into by those countries and the Union of South Africa. The fluctuations in this item of revenue are due to the fluctuations in the sailings of mail contract steamers, deductions from ocean mail contract payments being made for non-sailings. For example, in 1919-20 a deduction of 182.212 (or $57 / 104$ ths.) was made from the contract payment owing to the failure of the steamship company to convey the mails to South Africa 25 times and from South Africa 32 times.:

18 O.Y.B. 1918 , p. 686, and O.Y.B. 19 Auditor-Gensial's Repori for 1919.
1920.


Total Postal Revenue.

\begin{tabular}{|c|c|c|c|c|c|c|}
\hline Head of Revenue. & & $\begin{array}{c}1911-12 . \\
\mathfrak{f}\end{array}$ & $o_{0}$ & $\begin{array}{c}1913-14 . \\
f\end{array}$ & $\begin{array}{c}1917-18 . \\
\mathbb{E}\end{array}$ & $\begin{array}{c}1919-20 \\
£\end{array}$ \\
\hline P'ost Office Revenue & & 944,577 & 64 & $1,051,326$ & $1,167,825$ & $1,370,755$ \\
\hline Telegraph Revenue & & 329,139 & 22.5 & 370,008 & 380,024 & 475,231 \\
\hline Telephone Revenue & & $198,066^{\circ}$ & 13.5 & 263.792 & 425,752 & 523,641 \\
\hline
\end{tabular}

During the period under consideration the telegraph revenue was enhanced by 44 per cent., advaricing from $£ 329,139$ in 1911-12 to $£ 475,231$ in 1919-20, as compared with an increase of 35 per cent in the number of tclegraph offices open to the public, and 25 per cent. in the mileage of telegraph line. In 1917-18 there was a decrease in the ordinary paid traffic, but since the first quarter of 1918 there has been an appreciable expansion in the telegraph business.

With regard to the telephone receipts, there has been an extra-

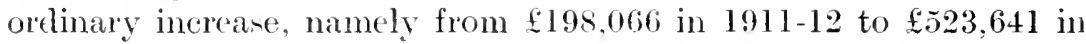
1919-20, an increase of 164 per cent. as compared with an increase of 175 per cent. in the mileage of telephone wire, and 100 per cent. it the number of telephones in use. Not only were increased facilities afforded to the public, but also the existing facilities were more fully used : and. in addition, the increased rates for trunk line services which came into operation in 1916 aceounted for a part of the extraordinary advances in telephone revenue.

Concerning the relative significance of the three distinct kinds of revenue handled by the Department of Posts and Telegraphs, an important alteration was effected. During the period from 1911-12 to 1919-20 the relative significance of the telephone revenue was considerably enhanced at the expense of both the postal and the telegraph revenue. Whereas in 1911-12 the telephone revenue was comparatively insignificant besirle the telegraph revenue, by 1919-20 the former had outstripped the lattei.

Summary of Financial Resulls.--The financial results of the post office, telegraphs, and telephones of the Union of South Africa may be most appropriately summarised in tabular form, the fact being taken into consideration that the expenditures as presented by the Department and adopted for the construction of the following table do not represent the total current expenditures from the commercial point of view, and that the revenue represents cash revenue, the value of free services rendered to other departments not being included. 
Heading.

Revenue $1911 \cdot 1$

$1913-14$

$1915-10$

$1917 \cdot 18$.

1919-20.

$\begin{array}{llllll}£ & £ & £ & £ & £\end{array}$

lixpenditure

$1,471,782 \quad 1,685,126 \quad 1,762,377 \quad 1,973,601 \quad 2,369,627$

Surplus or Defici

$1.491,204 \quad 1,658,097 \quad 1,655,705 \quad 1,821,128 \quad 2,387,362$

The Postal and Telegraph Administration of the Union has indeed succeeded in attaining the approximate equalization of revenues and expenditures, as qualified above, and thus realizing its aim to pay expenses and furnish the public with the means of communication at moderate rates. But, upon the application of business methods of accounting, it appears that the post office, telegraphs, and telephones constitute a losing enterprise. The value of free services rendered to other government departments is not nearly sufficient to offset the interest, depreciation and maintenance charges.

In spite of the rise in the eost of operation incident to the war. manifested in the form of higher salaries and wages as well as the increased cost of materials and transport, the Department did not have recourse to increases in rates and charges (with the exception of minor advanees in the telephone trunk line charges in 1916) during the entire period. The enlancement of the revenue as the result of the great expansion of business throughout the country was sufficient to meet the inerease in the expenditures occasioned by the factors referred to.

In view, however, of the deficit in 1919-20 and an anticipated further increase in the departmental expenditures, eertain rates and charges were increased in May, 1920, so as to yield additional revenue to the extent of $£ 400,000$ per annum; and in 1921 further increases were made. The penny postage has been raised to $2 \mathrm{l}$. per $\frac{1}{2} \mathrm{oz}$., the minimum eharge for a telegram to $1 \mathrm{~s}$. 3d., etc.

In such an enterprise as the post office the capital investment. if it could be accurately computed in the absence of a capital account, would be small as compared with other public enterprises. notably railways and harbours, as also the depieciation and maintenance charges. In respect of the telephone industry, however, the capital investment is high, and extensions and improvements necessitate new capital expenditure every year. The depreciation and maintenance charges are heavy, as the telephone instruments in use frequently become obsolete as the result of new inventions.

Financial Results of Post Office Savings Bank.-The Savings Bank is an adjunct of the Post Office and is operated by post office officials. in lieu of which an estimated amount is paid over each year to tho 
Postmaster-Gencral by the Public Debt Commissioners, to whom the investment of the funds of the Bank is entrusted. Any surplus that may result from the operations thereof is to be placed in a reserve fund, which was created primarily to provide against depreciation in the investments.

In 1919-20 the Savings Bank yiekled a net surplus of $£ 50,411$, which was assigned to the reserve fund, the balance of that fund being $£ 147,383$ on the 31st March, 1920, as indicated in the following tables.

Savings Bank Income Account" for the financial rear 1919-20.

To:

Interest on investments

profit on sale of strock

Balence, April 1, 1919

Surplus Interest
$B Y:$

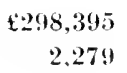

$\mathfrak{£ 0 0 , 6 7 4}$

$£ 300,674$

Reserve Fund.

$$
\begin{array}{rr}
\ldots 98,036 \\
\ldots \quad 50,411 \\
\hline \mathfrak{f} 148,447
\end{array}
$$

(4) Land and Agricultural Bank.

The Land and Agricultural Bank of South Africa was instituted by $l a w^{21}$ in 1912. Prior to that clate there were in operation three independent land banks, namely, the 'Transvaal Land and Agricultural Bank. the Land and Agricultural Loan Fund of the Orange Free State, and the Land and Agrieultural Loan Fund of Natal. On October 1, 1912, the three provincial banks ceased to exist, their assets and liabilities being taken over by the Land and Agrieultural Bank of South Africa, which might, for the sake of convenience be termed the "Union Land Bank."

Management and Control. (a) The Central Board.-The management of the bank is vested in a Central Board, consisting of a general manager (who is chairman) and four ordinary members, all of whom are nominated by the Governor-General.: (b) Local Boards.-In acklition to the Central Board there are local boards, eomposed of three members, who are likewise nominated by the Governor-

\footnotetext{
20 Auditor-ceneral's Repont for 1919 2 Aet is of 1912. I!? 1). P +(i).

22 Ibirl, sec's. 1 and 5 .
} 
General. These loeal boards, of which there are four in the Union, are endowed with advisory functions only. ${ }^{23}$ (c) Agents for the Baml. -Magistrates, field-eornets, police officers, and post office officials are direeted by law to act as agents of the bank, if the Central Board requires their assistanee in any matter.

Capital of Bank.-The Union Land Bank eommeneed operations with a eapital of $£ 2,735,000$, representing the loans made by the Colonial Governments, and by the Union Government during the period from May 31, 1910, to September 30, 1912. The amount of the eapital is not fixed but is subject to inerease to the extent of : (a) such sums of money as Parliament may from time to time by appropriation authorise the Minister of Finance to pay to the bank as part of its funds; and (b) such sums as the bank ean secure in conneetion with the advances made by the Union Government or the Colonial Governments for the construction of dipping tanks and the feneing of farms, whether the amounts recovered represent repayment of prineipal or interest or other charges in regard thereto."

In 1921 the Land Bank was authorised by Parliament to raise, upon sueh terms and conditions as it may determine, further funds by : (a) diseounting, with other banks, bills of eo-operative societies ; (b) overdrafts with other banks; and (c) issuing Land Bank bills

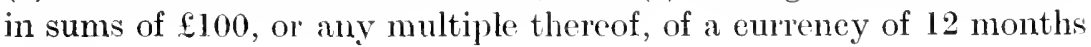
or less.

Such funds are to be employed solely for the purpose of finaneing eo-operative soeieties in the form of eash eredit accounts.

At the end of 1919 the capital of the Land Bank amounted

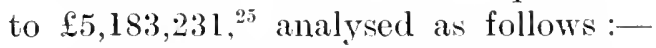

Capital Funds taken over from Provincial Land Banks in 1912 Advances received from the Union Treasury since 1912 Recoveries of advances for dipping tanks and fencing. .
$12,735,1) \times(0$ $2,275,000$

173.231

Total

$\mathfrak{f 5}, 183,231$

On September 30, 1922, the eapital amounted to $£ 6,161,338$.

The Land Bank Aet provides that the bank shall pay interest on its eapital at the rate of $3 \frac{3}{4}$ per ecnt. per annum (with the exeeption of the advances made by the Transvaal Land Bank in accordinnee with the Feneing Act of 1908 at the rate of $3 \frac{1}{2}$ per eent.), but that this rate of interest may be raised or lowered by deeision of Parliament. ${ }^{-1}$ In 1914 Parliament raised the interest to $4 \mathrm{per}$ cent. on advanees made to the bank after April 1, 1914. At the end of 1918 the interest

23 Act 18 of 1912 , sec. 13 .

2f Ibidl, ser. $20(1)$.
25 Auditor-General's Report for $1: 19$. 1920 , 1. 381.

26 Act 18 of 1912 , see. $20(2)$. 
payments were constituted as follows : $3 \frac{1}{2}$ per cent. on $\mathfrak{1 2}, 785,3 \frac{3}{4}$ per cent. on $\mathfrak{f} 4,268,225$, and 4 per cent. on $£ 625,000$, involving a total payment of $\mathfrak{E} 186,5.56$ as interest for the year. ${ }^{27}$

Functions of the Bank.-The main purpose of the bank is to make advanees :- $-(a)$ to farmers on security of first mortgage on arable and pasture lands, the amount of the advanee not to exceed . $\$ 2.000$, or 60 per eent. of the value placed on the land by the Central Board; (b) to settlers who oceupy Crown land on the leasing system or who hold Crown land under agreement of purchase ; $(c)$ to farmers for the construction of dipping tanks and for fencing; $(d)$ to co-operative agricultural associations upon the joint and several liability of the members for the debt of the soeiety and upon such additional security as the board may require. ${ }^{28}$

Purposes for which adrances may be made.--Advanees may be made by the Land Bank for the following purposes:--(a) purchase of land for agricultural and pastoral purposes; $(b)$ discharge of existing liabilities on land or, in special circumstances, any other existing liabilities ; (c) purchase of stock or plant of all kinds and of agricultural requirements generally; $(d)$ improvements. ${ }^{29}$

The following table ${ }^{3 \prime}$ indicates the nature and extent of the operations of the Land Bank :---

Purpose of Adrance.

Purchase of Land

Discharge of Existing Liabilities

Purchase of Stock ... ...

Tmprovements ... ... ...

Hiscellaneous ..

\begin{tabular}{|c|c|c|}
\hline 1914. & 1916. & 1918. \\
\hline E & $\mathfrak{E}$ & \pm \\
\hline 157,960 & 244,3211 & $412,74 t$ \\
\hline $107,0.57$ & 128,228 & 420,805 \\
\hline $41,56 t$ & 47,044 & 62,832 \\
\hline 46,831 & 53,920 & 51,574 \\
\hline 952 & 865 & 390 \\
\hline \pm 3.54 .361 & $£ 47 \neq, 377$ & $\mathfrak{f} 948,345$ \\
\hline
\end{tabular}

$\begin{array}{rrrr}\ldots & \ldots & \ldots & 952 \\ \ldots & \ldots & \ldots & £ 354.361\end{array}$

Financial Results.-During the period from Oetober, 1912, to

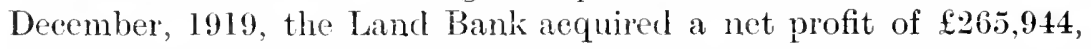
which was placed in the reserve fund in accordance with the provisions of the law. The Land Bank Act further stipulates that the reserve fund shall be applied to the liquidation of any losses or deficits that may ocew in any of the transactions of the bank. ${ }^{31}$ Up to the end of 1919 there had been no loss or deficit. On December 31 , 1919, the reserve fund comprised an amount of $£ 341,370$, composed of the sum of $£ 75,926$ taken over from the reserve fund of the provineial land banks, and the net profit of $£ 265,944$ acquired

27 O. Y.B. 1919 , p. 487 .

28 Act 18 of 1912 . secs. 23 and 28 .

c9 Ibid, sec. 19.
30 O.Y.13. 1919, p. 881.

31 Act 18 of 1912 , sec. $43(2)$. 
by the Union Land Bank. ${ }^{32}$ On September 30, 1922, the reserve

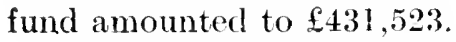

The bank is operated in accordance with commereial principles, but its aim is not to make large profits, and the Act stipulates that, as soon as the reserve fund amounts to $\$ 500,000$, the Central Board is to notify the Minister of Finance of that fact, who is then to submit the matter to the deliberation of Parliament as regards a possible reduetion of the interest on the loans or advances of the bank, in order to maintain the income of the bank as nearly as possible at the amount required to cover its working expenses and the interest payable to the Treasury. ${ }^{33}$

By 1919 the operations of the Land Bank had been sufficiently extended to leave an annual sum of $f 400,000$, representing the proceeds of repaid loans, available for re-investment, but in eonsequence of the development of the agrioultural industry throughout the Union and the accompanying requirement of capital, it is still necessary for Parliament to supplement the capital of the bank. However, the time does not appear to be very remote when the Union Land Bank will be in a position to discharge its functions entirely independent of the Treasury.

While as an independent enterprise the Union Land Bank has been successful, yielding a substantial net profit every year, it does not represent a paying investment for the Union Treasury, in view of the fact that the rate of interest payable on the advances from the Treasury to the Land Bank was still 4 per cent. by March 31, 1920, whereas the rate of interest on Govermment loans had been 4.1 and 5 per cent. since 1915. The Treasury had decided to raise the interest on Loan Fund issues to a figure which would represent the cost to the Treasury of borrowing the money, but on the aforementioned date no action had been taken.

It would seem more advisable, therefore. to relinguish the annual surplus earned by the Land Bank in favour of an increase in the rate of interest on loans from the Treasury rather than a recluction of the interest on the adrances of the bank iticelf. However, the main aim of the Union Government in respect of the Land Bank is the promotion of the development of agriculture in South Africa, and with a view to realizing this aim the loss ineured by the Treasury may be regarded as justifiable.

In 1921 it was further provided that, as soon as the reserve fund and the eapital of the bank total such amount as is, in the board's

\footnotetext{
32 Auditor-General's Report for 1919 . 1920 , p. 382 .

33 Act 18 of 1912 . sec. $43(4)$.
} 
opinion, adequate to enable the bank fully to carry out its objects, there is to be paid each year to the Minister such amount as the board shall direct out of $(a)$ the profits of the bank, and $(b)$ the reserve fund of the bank, provided that the amount of the reserve fund shall not be reduced below $£ 350,000$. All such amounts are to be applied by the Minister towards redemption of the capital funds of the bank.

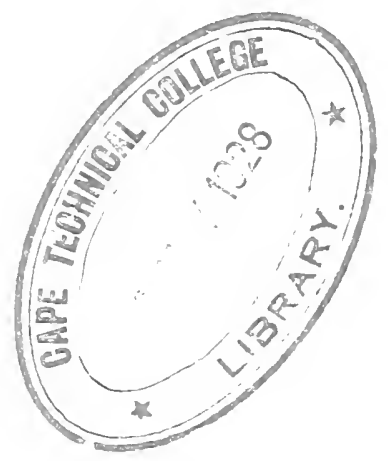




\title{
2. DOMAINS.
}

\author{
CHAPTER :?.
}

\section{Crown Lands and Land Settlement. Forrestry.}

\section{Crown Lands and Land Settement.}

'The administration of Crown lands and of land settlement within the Union of South Africa is vested in the Minister of Lands, who is responsible to Parliament for the activities of the Department of Lands, the permanent head of which is the Secretary for Lands.

Prior to the establishment of the Union each Colony administered its Crown lands under certain statutory provisions. In 1912 the Union Parliament passed a land settlement act ${ }^{1}$ with a view to securing uniformity of practice in the four provinees regarding the aequisition, exchange, and disposal of Crown lancls. The act, which represents an addition to. rather than a substitute for, any previous law, has proved generally satisfactory in its operation and has conformed to the needs of the time. An amending act ${ }^{2}$ was passed in 1917 and in 1920 to improve the terms and eonditions provided by the original act.

The main provisions of these acts empower the Minister of Lands :

(a) to acquire private land by purchase or exchange for land settlement purposes, and, after division into suitable holdings. advertisement in the Government Gazette and local newspapers. to dispose of such land or Crown lands similarly treated to approved applicants, on- lease for five years with an option to purchase extended over twenty-years ;

(b) to acquire and allot particular land seleeted by an applieant who is prepared to contribute in cash at least one-fifth of the total cost thereof $;^{4}$

(c) to make advances not exceeding $£ 500$ in amount to lessees under the acts for the purposes of developing their holding $\mathrm{s}^{5}$

(d) to cause boring operations to be effected or improvements of a substantial and permanent nature to be erected or con-

1 Act 12 of 1912 .

2 Act 23 of 1917.

3 Act 12 of 1912 , sers. 10 and 16 .
4 Ibid, sec. 11.

5 Act 28 of 1920 . 
structed, and to add the cost thereof to the purchase price of holdings. ${ }^{6}$

The following table ${ }^{i}$ serves to indicate the extent of the operations under the Union land settlements acts, from the passing of the first act in 1912 to March 31, 1919:

Heading.

$\begin{array}{lllll}\text { Lessees } & \ldots & \ldots & \ldots & \text { No. } \\ \text { Area ... } & \ldots & \ldots & \ldots & \text { Acres } \\ \text { Taluation } & \ldots & \ldots & \ldots & \mathfrak{£}\end{array}$

From October, 1912, to

Mlarch $31,1919$.

2,169

$4,236,675$

$1,479.783$

Unalienated Crown Land within the Union of South Africa.-In March. 1919, the approximate area of Crown land which may ultimately be taken up for agricultural or pastoral purposes was $43,080,242$ acres. distributed as follows : Cape Province, 26,713,330 acres; Transval, 13,900,886 acres; Natal, 2,466,026 acres. 'There is practically no unalienated Crown land in the Orange Free State. Successful boring operations would conduce to these lands being converted into farms on which prospective lessees might, with a fair hope of success, make a living.

Capital Expendilure in respect of Land Settlement.-During the ten-year period from the establishment of the Union in 1910 to March 31 , 1920, the sum of $£ 2.583,288^{\circ}$ had been expended on land settlement from hoan funds. Of this amount more than one-half, namely $f 1,374.720$, was disbursed during the two years from April. 1918, to March, 1920. This great increase of activity in respect of land settlement is mainly to be attributed to the obligation of the Union Government to provide for the returned soldiers. In the estimates for 1920-21 provision was made for an appropriation of $£ 977,000$ in regard to land settlement. 'Thus, while the outbreak of the war occasioned the reduction of capital expenditure on land settlement to a negligible amount, namely £189,218 in 1914-15 and $\$ 57,113^{10}$ in $1915-16$, the termination of hostilities served as a decided stimulus to the activities of the Department of Lands, in its attempt to solve the problem accompanying demobilization by the settlement of soldier's on the land, and at the same time to promote agricultural development.

Ordinary Expenditure on the Administration of Crown Lands and Land Settlemem Schemes.-The following table," giving parti-

6 Act 12 of 1912 , see. 44 .

7 O.Y.B. 1919 , pp. $478,79$.

8 Ibid, p. 484.

9 S.Y.B. $1914-15$ p. 232 , and Q.S. of Union statisties, Oct. 1920, p. 7s.

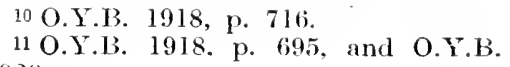
1920. 
culars as to the expenditure from general revenue on the administration of Crown lands and land settlement schemes, indicates the features peculiar to several items of expenditure, namely, a sharp reduction during the first two years of the war due to the policy of retrenchment and economy as the result of a shrinkiage in the yield of certain sources of revenue, followed by a gradual increase in expenditure until 1918, after which year the expenditure was considerably enhanced in consequence of the elaboration of the war-bonus system in that year and the general inerease in salaries and wages authorized in 1919, as well as the increased cost of materials.

Ordinar Expenditure on Crown Lands and Land Settlement.

Head of Expenditure. 1911-12. 1913-14. 1915-16. 1917-18. 1919-20.

\begin{tabular}{|c|c|c|c|c|c|c|}
\hline & & $\mathfrak{E}$ & $i$ & 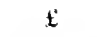 & $£$ & $\mathfrak{f}$ \\
\hline Salaries and Wages & $\ldots$ & 29,115 & 33,337 & 35,334 & $42,6+4$ & 62,366 \\
\hline Government Surveys & $\ldots$ & 20,313 & 15,849 & 12,126 & 8,144 & 7,824 \\
\hline \multicolumn{7}{|c|}{ Fencing and Maintenance } \\
\hline of Crown Land & $\ldots$ & 1.550 & 6,300 & 3,202 & 7,006 & 18,504 \\
\hline Miscellaneous & $\ldots$ & 48,972 & 36,213 & 11,066 & 24,308 & 29,590 \\
\hline Total $\ldots$ & $\ldots$ & 99,950 & 91,699 & 61,728 & 82,107 & $118,28.4$ \\
\hline
\end{tabular}

Revenue from Crown Lands and Land Settement Operations.

1. Receipts from the Sales of Crown Lands.-Up to the financial year 1915-16 the receipts from the sale of Crown lands constituted an item of ordinary revenue and were applied toward the payment of the general expenditure of the Union Government. In 1916, however, it was resolved by Parliament to credit such receipts to the Loan Account instead of the Revenue Account, to be devoted to the payment of non-recurrent expenditures. At the time the national debt had been increased by about $£ 20,000,000$ on account of the German-South-West-African campaign, and it was realized that the credit of the Union Government was liable to be impaired by the application of the revenue from the sales of Crown lands toward the payment of current expenditures, as such sales diminish the value of the security against which loans are raised. Thus, subsequent to 1916 the receipts from the sale of Crown lands have been credited to the Loan Aecount and have served to stay the growth of the publie debt to the extent of their amount. However, on account of the anticipated reduction in revenue for the year 1921-22 by several millions: of pounds sterling as the result mainly of the clepression in the mining industry, the Minister of Finance, in his budget specel delivered in April, 1921 , intimated the intention of the Government. 
with the approval of Parliament, to apply such receipts to the payment of current expenditures, the matter to be treated as an emergeney measure.

In public finance the ideal principle is to devote the entire receipts from the alienation of assets of the State to the redemption of deht, but in a new and partially undeveloped country, such as the Union of South Africa, where it is the duty of the Government to build up a patrimony for future generations, that principle may be modified to imply that one-half of such receipts is to be applied towards the payment of current expenditures, and the other half towards loan redemption.

The following table ${ }^{12}$ shows the amount of the revenue from the sale of Crown Lands devoted to the payment of ordinary expenditures, from 1911-12 to 1915-16.

\section{Revenue from the Sule} of Crown Lands.

$\begin{array}{cccccc} & \text { Fiscal Year. } & & \mathfrak{f} \\ 1911-12 & \ldots & \ldots & \ldots & \ldots & 85,034 \\ 1912-13 & \ldots & \ldots & \ldots & \ldots & 53,903 \\ 1913-14 & \ldots & \ldots & \ldots & \ldots & 47,824 \\ 1914-15 & \ldots & \ldots & \ldots & \ldots & \mathbf{2 5 , 7 7 8} \\ 1915-16 & \ldots & \ldots & \ldots & \ldots & 95,420\end{array}$

Subsequent to 1916 the amounts realized from such sales were larger than before, as indicated in the following table:- ${ }^{13}$

$$
\begin{gathered}
\text { Revenue from the sales } \\
\text { of Crown lands. }
\end{gathered}
$$

$\begin{array}{llllll}1916-17 & \ldots & \ldots & \ldots & \ldots & 113,011 \\ 1917-18 & \ldots & \ldots & \ldots & \ldots & 127,187 \\ 1918-19 & \ldots & \ldots & \ldots & \ldots & 201,178 \\ 1919-20 & \ldots & \ldots & \ldots & \ldots & 193,758\end{array}$

Thus, the total amount secured by the Union Government from the sale of Crown land chring the period from 1911-12 to 1919-20, was 8943,093 , of which $£ 307,959$ was assigned to the lievenue Aceount and $\$ 635,134$ to the Loan Account.

2. Quitrents.-Quitrents which represent in most cases merely the purehase price of Government land have been imposed in the Cape and Natal Provinces. In Natal the quitrent is fixed in terms of grant according to a rate laid down by Proclamation or according to the value of the land. In the Cape Province the quitrent, which

\footnotetext{
12 O.Y.B. 1918, 1. 679.

13 Half-yearly Abstract of Union Statistics, Jume 1919, P. \&1, and

Auditor-General's Report for 1919-20, p. 72 .
} 
is fixed by contract, is based generally on the value of the land or purchase price. The quitrent may be redcemed at 15 or 20 years' purchase, the redemption charge being the purchase price and the quitrent payable being approximately 5 per cent. interest on such purchase price. In Natal the quitrent has now been almost entirely redeemed.

The revenue derived from quitrents constitutes an item of ordinary revenue and is assigned to the Revenue Account. The following table $^{14}$ shows the net receipts derived from quitrents in the Cape Province during the period from 1912-13 to 1916-17, and the number of persons subject to quitrent :

$\begin{array}{rcrrc}\text { Fiseal } & \text { Year. } & & \begin{array}{c}\text { Net Receipts. } \\ \mathfrak{E}\end{array} & \text { No. of Persons. } \\ 1912-13 . & \ldots & \ldots & 101,322 & 49,735 \\ 1913-14 & \ldots & \ldots & 104,018 & 51,748 \\ 1914-15 & \ldots & \ldots & 101,532 & 50,283 \\ 1915 \cdot 16 & \ldots & \ldots & 107,970 & 51,36.1 \\ 1916-17 & \ldots & \ldots & 110,826 & 54,100\end{array}$

3. Rents of Crown Lands and Native Locations.-The amount of revenue obtained during the year 1916-17 in the form of rents of Crown lands and native locations is given hereunder $:^{15}$

Head of Revenue.

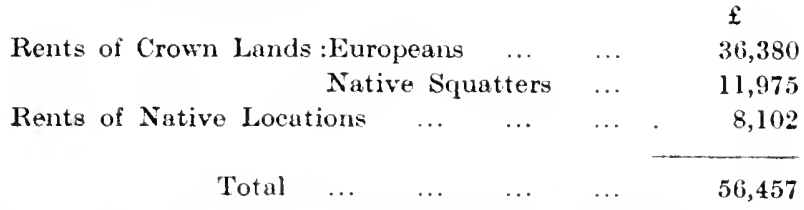

4. Interest on Investment in Land Seltlement Schemes.-The following table ${ }^{16}$ shows the amount of interest collected by the Department of Lands during the three years from 1916-17 to 1918-19, such interest being paid into the Revenue Account towards meeting the interest on the public debt:

Fiscal Year.

\begin{tabular}{cccccc} 
& & & & \multicolumn{2}{c}{$\mathfrak{E}$} \\
$1916-17$ & $\ldots$ & $\ldots$ & $\ldots$ & $\ldots$ & 101,552 \\
1917.18 & $\ldots$ & $\ldots$ & $\ldots$ & $\ldots$ & 105,000 \\
$1918-19$ & $\ldots$ & $\ldots$ & $\ldots$ & $\ldots$ & 101,239
\end{tabular}

Loan Recoveries.-Loan recoveries in respect of land settlement, including that portion of the instalment payments which represents

\footnotetext{
14 Report of the Commissioner for Inland Revenue, 1916-17, p. 16. 16 O.Y.B. 1918, p. 396, and O.Y.B.

15 Report of Commissioner for Inland 1919 , p. 485.

Revenue, 1916-17, p. 26.
} 
a repayment of principal, are assigned to the Loan Account and may be applied to new schemes.

Summary of financial results of the Administration of Crown Lands and Land Sellement Schemes.-The Union scheme of land settlement, as at present conducted, represents a losing proposition, constituting a direct financial loss to the Treasury of several thousands of pound per annum. The reasons for this loss are as follows:

(1) The interest clarged by the Government in connection with land settlement schemes was 4 per cent, until recently, whereas the rate of interest on loans floated by the Government during the last five vears has been $4 \frac{1}{2}$ and 5 per cent. All the large loans that have been floated at par since 1915 bear 5 per cent. interest. (Since May 1, 1922, the rate of interest chargeable in respect of land sales and advances to settlers has been fixed at 5 per cent.)

(2) In the case of allotments of private land acquired by purchase for land settlement purposes and leased for five years with an option to purchase extended over twenty vears, the rentals charged on the allotment price are $(a)$ for the first year, nil, $(b)$ for the second and third years, 2 per cent. per annum, and $(c)$ for the fourth and fifth years, $3 \frac{1}{2}$ per cent. ; and in the case of land specially purchased for applicants no payments are made during the first two years.

(3) Amounts totalling several thousands of pounds sterling are annually written off as irrecoverable. For example, in 1919-20 the amount written off was $£ 16,670,{ }^{17}$ a portion of which represented unaccrued instalments of the purchase price of allotments in the case of holdings which have been resumed by the Government, owing to failure of the settlers to carry out the terms of their purchase.

If land settlement is to prove self-supporting, the rate of interest charged to settler's should be slightly in excess of the rate at which the Government has to borrow, so as to allow for cost of administration. irrecoverable amounts, and the like. The Union Government has probably been indirectly compensated for the direct financial loss incurred in land settlement schemes by means of the increased yield of certain sources of revenue as a result of increased agricultural development; in fact, the promotion of agricultural development and of the settlement of an agricultural population in the inland portions of all the provinces of the Union constituted the main aim of the Government.

Net Revenue derived from Crown Lands and Land Settlement.Taking 1916-17 as a typical normal year. the following computation

17 Report of Auditor-Ceneral for 19]9-1920, p. 352. 
may be made in the attempt to arrive at the amount of net revenue derived from Crown lands and land settlement, considered as a joint activity of the Union Govermment :-

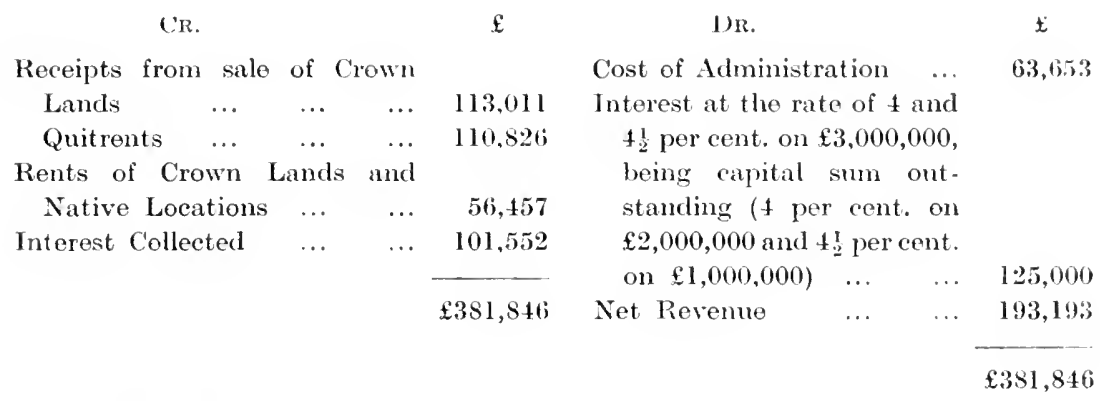

\section{For estry.}

Organization of the Forest Department.- The Forest Department is under the control of the Chief Conservator of Forests, and is a subdepartment of the Union Department of Agrieulture. For the accomplishment of the twofold purpose of preserving the existing forests and providing the eountry with a new and more ample supply of timber and ornamental trees, the Union is divided into seven Conservancies, in each of which nurseries and plantations are established.

Each Conservancy is controlled by a Conservator of Forests and is divided into distriets, which again are under the supervision of District Forest Officers. Each district usually comprises several forest stations which are in charge of Foresters.

The Financial Results.--In view of the fact that South Africa is a poorly timbered country, about 6 million cubie feet of timber being imported every year whereas only about 1,500,000 cubic feet are anually produced in the Union, and that forestry is undertaken by the Union Government, not as a source of net revenue but as the means of preserving the existing forests, of inereasing the production of timber by the estabishment of new plantations, and of encouraging the general afforestation of the country by the development of nurseries and the sale of tramsplants and seeds at very low prices, the test of success, as applied to forest administration in South Africa, does not require either the attainment of a surplus or the balancing of revenues and expenditures. Under the peculiar circumstances the results aimed at are not capable of realization, except at the expense of the taxpayer. However, the test of financial success may be taken to preseribe that the poliey of

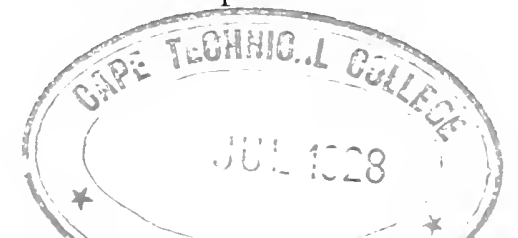


the forest department be carried into effeet without imposing an excessive burden on the taxpayer and this requirement may be justifiably regarded as implying that the revenue shall cover about half of the expenditure. This has been the aim of the forest department and has been attained within reasonable limits during the decade 1910-1920.

The following table ${ }^{18}$ shows the variations in ordinary expendi. tures in respect of forestry, as a result of war conditions:-

\begin{tabular}{|c|c|c|c|c|c|}
\hline Head of Expenditure. & $1911 \cdot 12$ & $1913-14$. & $1915-16$. & 1917.18. & $1919 \cdot 20$ \\
\hline & $£$ & $\boldsymbol{\epsilon}$ & $\mathfrak{f}$ & $\mathfrak{f}$ & $\mathfrak{E}$ \\
\hline Salaries and Wages & 34,214 & 38,457 & 38,316 & 46,606 & 68,672 \\
\hline Nurseries and Plantations & 49,919 & 64,065 & 40,713 & 50,571 & 56,137 \\
\hline Forest Protection and & & & & & \\
\hline Development & 7.805 & 7,101 & 5,523 & 5,301 & 7,637 \\
\hline $\begin{array}{r}\text { Afforestation by } \\
\text { white labour }\end{array}$ & & 一 & - & 17,799 & 21,604 \\
\hline Miscellaneous $\quad \ldots$ & 19,697 & 11,204 & 10,503 & 11,008 & 16,954 \\
\hline Total & 111,635 & 120,827 & $£ 95,055$ & $£ 131,285$ & $£ 171,004$ \\
\hline
\end{tabular}

The increase in expenditure in 1913-14, as compared with 1911-12, is to be attributed to the extension of the activities of the forest department, the main inerease being registered in respect of nurseries and plantations. This normal extension of departmental activities was obstrueted by the outbreak of the European War and by the shrinkage in the yield of eertain sources of revenue, which necessitated a poliey of retrenchment and eeonomy. As a result the expenditure in 1915-16 showed a substantial derrease as eompared with 1913-14. The eeonomy was effeeted mainly in eonneetion with nurseries and plantations. By 1917-18 the fiseal system had been readjusted so as to yield the increased revenue required for ordinary governmental purposes, and the depreciation in the purehasing power of money had manifested itself in a substantial inerease in expenditure, an increase of almost 40 per cent. over 1915-16. In addition, the sum of $£ 17,799$ was expended in that year for afforestation by white labour. Afforestation was one of the methods employed by the Union Government in their attempt to solve the poor-white problem. At the time there was acute distress in certain sections of the Union as the result of a severe drought followed by floods. Representations were made to the Government, and various measures were taken for the relief of clistress, one of them being the absorption of poor whites in new afforestation schemes.

18 O.Y.B. 1919, p. 852, and Appropriation Aceounts 1919.20, p. 28. 
The expenditure on forestry was further enhanced after $1918 \mathrm{by}$ the sharp rise in the cost of living and of materials of all kinds, as well as by an increase in the staff.

The forest revenues illustrate the same variations as the expenditures during the period under consideration, namely, a deerease in the first two years of the war followed by an annual inerease. The following table ${ }^{19}$ exhibits the various subdivisions of forest revenue :

Head of Revenue. 1914.15. 1916.17. 1917.18.

\begin{tabular}{rrrrrr} 
& & & \multicolumn{1}{c}{ \pm} & \multicolumn{1}{c}{} & \multicolumn{1}{c}{$£$} \\
Timber & $\ldots$ & $\ldots$ & 16,613 & 26,527 & 33,565 \\
Firerrood and & \multicolumn{1}{c}{ Charcoal } & 10,307 & 10,639 & 11,920 \\
Bark $\ldots$ & $\ldots$ & $\ldots$ & 1,809 & 1,877 & 881 \\
Hut-rattles & $\ldots$ & $\ldots$ & 1,708 & 1,617 & 2,241 \\
Minor produce & $\ldots$ & $\ldots$ & 13,823 & 17,193 & 16,748 \\
& & & & & \\
Total & $\ldots$ & $\ldots$ & 44,260 & 57,853 & \\
\end{tabular}

The sale of timber constitutes the main source of revenue and is tending to increase in importance. In 1914-15 the revenue from timber represented less than 40 per cent. of the total forest revenue. whereas in 1917-18 the percentage was more than 50. Also the timber receipts were enhaneed by more than 100 per cent. during the three-year-period from 1914-15 to 1917-18, duc to the increased yield of the plantations. The yield of timber from the indigenous forests showed a small increase, namely, from 909,331 cubic feet in 1914-15 to 960,898 eubic feet in 1917-18, whereas the yield or timber from plantations was increased from 180,256 eubie feet to 629,362 cubic feet during the same period." The increase in the timber receipts accounts for almost the entire increase in the total forest revenue.

With regard to the minor produce, the most important single item is the sale of transplants and cuttings, which is likewise tending to increase in importanee. During the financial year 1914-15. $2,851,600^{21}$ transplants were sold from the Government nurseries. whereas in 1917-18 the number of transplants sold was $4,558,652,2=$ an increase of 60 per cent. The other items under the heading "minor produce" are the receipts from the sale of sceds, from grazing and cultivation, from licences for the eollection of buchu leaves on the forest reserves, or of flower's, bush tea, etc.

19 Lait's Commercial Blue Book for South Africa, 1916, p. 339 and O.Y.B. 1918 , p. 456 .

20 O.Y.B. 1918, ก. 457.
21 Laite's Commercial Blue Book. 1916 , p. 339.

22 O.Y.B. 1919, p. 573. 
Summary of Financial Results.-The following table serves as an adequate summary of the financial results of forestry in South Afriea during the period in question :

\begin{tabular}{|c|c|c|c|c|c|c|c|}
\hline Heading. & & $\begin{array}{c}1911-12 . \\
£\end{array}$ & $\begin{array}{c}1913-14 \\
\mathfrak{E}\end{array}$ & $\begin{array}{c}1915 \cdot 16 . \\
£\end{array}$ & $\begin{array}{c}1917 \cdot 18 \\
\mathfrak{f}\end{array}$ & $\begin{array}{c}1919-20 . \\
\mathfrak{f}\end{array}$ & $\begin{array}{c}1920-21 \\
\mathfrak{f}\end{array}$ \\
\hline Expenditure & $\ldots$ & 111,635 & 120,827 & 95,055 & 131,285 & 171,004 & 215,554 \\
\hline Revenue & $\cdots$ & 55,224 & 50,603 & 51,978 & 63,767 & 117,256 & 107,220 \\
\hline fic & $\cdots$ & 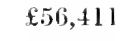 & $\mathfrak{f} 70,224$ & $£ 43,077$ & $\mathfrak{f} 67,518$ & $\mathfrak{f 5 3 , 7 4 8}$ & $£ 108,334$ \\
\hline
\end{tabular}

The revenue referred to in the above table represents eash revenue only ; but gratis issues are made every year to the extent of several thousands of pounds sterling. In 1914-15, for example, the gratis issues involved an amount of $£ 14,147 .^{23}$ However, taking merely the cash revenue as a basis, it is observed that, on the whole, the revenue covers about one-half of the expenditure. In 1913-14 the revenue represented slightly more than 40 per cent. of the expenditure, whereas in 1919-20 the pereentage was more than 67 , but spread over a number of years the revenue constitutes about onehalf of the expenditure, which does not by any means represent a heavy burden on the taxpayer for the valuable services rendered to the community in the form of forest conservation and afforestation.

Moreover, the inerease in the yield of timber from plantations bids fair to equalise revenues and expenditures in the near future. The great increase in revenue after 1915 is mainly to be contributed to increased sales of timber. ${ }^{2 t}$ The yield from the plantations has been so encouraging that the Union Government has embarked upon the policy of applying moneys from the loan fund towards the extension of afforestation and the purchase of land for such purposes. In 1918-19 the sum of $£ 38,000$ was expended on afforestation from the loan fund; in 1919-20 the capital expenditure amounted to $\mathfrak{f} 11,244,,^{25}$ and in the estimates for $1920-21$ provision was made for an appropriation of $£ 59,000^{26}$ in respect of forestry.

Prior to 1918 all expenditure on afforestation has been met from ordinary revenue, but in that year it was decided to extend the work of afforestation in view of its remunerative prospeets and its aceordance with the public welfare, and to provide for such extension and for the purehase of land specially suited for afforestation out of oan funds. Up to that time afforestation was confined to the old

27 Laite's Commercial Blue Book, 1916 , p. 339 .

a4 Report of Auditor-General for 1919. 1.920. p. 88 .
25 Ibid, p. 425.

26 Q.S. of Union Statistics, Oct. 1920 , p. 78 . 
Government forest reserves, which are situated on Crown lands and which therefore did not neeessitate any expenditure on the part of the Government for the purchase of forest lands. The new poliey embodies the eonvietion that afforestation requires land specially suited for the purpose, if it is to prove remunerative.

The eonclusion may therefore justifiably be drawn that the forest department of the Union of South Afriea is well on its way to removing the present burden on the taxpayers in respect of forestry. The burden has been light in comparison with the advantages to be derived from the activities of the forest department. Forestry will probably never prove to be a profitable adjunct of the Union Government, but it shows every promise at present of according inestimable benefits to the present generation and more so to posterity at eomparatively small cost. 


\section{(HAPTER 4.}

Mining Laxds anil Mining Rights. Irrigation. Guano Istaxids.

\section{Mining Lands and Mining Rights.}

(a) Government Ounership Share of profits in Diamond Mines.In accordance with the provisions of the Transvaal Precious Stones Ordinance of 1903 , the State is entitled to a six-tenths share of any diamondiferous land that is proclaimed a mine. ${ }^{1}$ The Premier Diamond Mine is practically the only diamond mine in the Transval that is deserving of mention. Mining operations were commenced in 1903, the year in which the abovementioned ordinance went into effect. The proprictors of the Premier mime might have taken the four-tenths share to which they were entitled, and worked that part of the mine without any further liability to taxation. In view, however, of the difficulty of ascertaining in which part of the diamondiferous area the pipe was loeated, they elected to work the whole area of the mine. thus, virtually entering into a partnership with the Govermment, to whom they are required to pay six-tenths of the net profits earned.

In the Cape of Good Hope and the Orange Free State similar precions stonc laws are in force, but the great producing coneerns in these provinces, namely, the De Beers Consolidated and the Jagersfontein mines respectively. arc only subject to taxation in the form of the profiti taxes applying to all mining eoneerns, these mines having been in operation at the time of the promulgation of such laws.

In the Orange Free State. the State is entitled, under the Mining of Precious Stones Ordinance of $190 \frac{1}{4}$, to a four-tenths share in any diamond mine on private land. but in cases where a small mine is proclaimed, not exceeding 135,000 square feet in area, the Government may lease the portion owned by the Crown to the owner or minc-holder on such terms as may be agreed upon.: In accordance with this provision, the Government has leased to three small diamond mining companies operating in that province the 40 per cent. interest owned by the Crown. As consideration for the lease

\footnotetext{
1 Ordinance of 1903,66 (Transvaal)

2 Ordinance 4 of 1904 (O.F.S.), sec. 50 ser. 27 (1).
} 
of the Crown's share the mines pay annually a percentage of the profits to the Government in the form of a royalty.

Heneeforth, all new diamond mines will be subjeet to partnership with the Union Government, whether proelaimed in the Transvaal, the Crange Free State, or the Cape Province.

During the deeade from 1910 to 1920 the Union Government derived a eonsiderable revenue from its ownership share of profits in diamond mines, the amount being about $£ 3,500,000$ for the tenyear period. The annual revenue from this source varied appreeiably during that deeade, depending upon the prevalence of prosperity or depression in the diamond mining industry, as illustrated in the following table :"

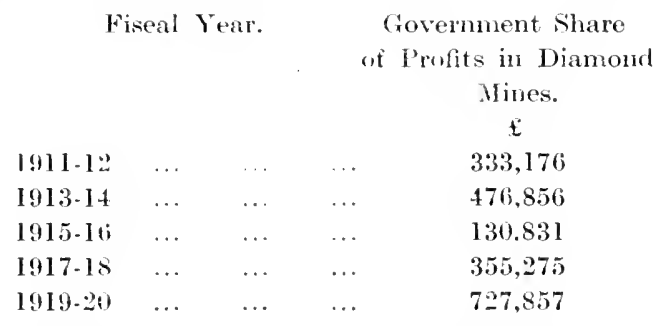

The low mark of 1915-16 was oceasioned by the disturbance in the diamond industry in eonsequence of the ontbreak of the War, and the high mark of 1919-20 was the result of the exceptionally high prices obtained in that year.

This form of revenue is regarded as an item of ordinary revenue, payable into the Revenue Account to be applied towards the payment of the current expenditures of the Government. This action is not in eonformity with the prineiples of sound finance. which would prescribe that one-half of such receipts should be devoted to the redemption of debt, in view of the diminution in the value of the mineral assets of the State, and the other half to the payment of current expenditure, in view of the fact that no taxation is payable on the Government's share of the profits of the mine, and that the state is building up a patrimony for future generations.

(b) Leases. (1) "Public Diggings."-Under the old Transval mineral laws the right of mining for and disposing of all precious metals is vested in the Crown. Whenever precious metals liave been found on Crown or private land, and the Government is satisfied that they exist in payable quantities, it may proclaim such land a publie digging. In the case of private land the owner of the Mineral 
rights has the right to select either one or two areas called a "mynpacht," which may not in the aggregate exceed one-fifth of the extent to be proclaimed, while the owner of the freehold has also the the right to a certain reservation for homestead and agricultural purposes. ${ }^{*}$

Under the provisions of the Transvaal Precious and Base Metals Act of 1908, the Government is empowered to lease to any person the exclusive right to mine for precious metals on publie diggings. The consideration payable to the Government in respect of such leases is an agreed share on a sliding scale percentage basis of the annual profits, prescribed as follows in the Mining Leases Act of $1918^{5}$ :

Profits expressed as a percentage of revenue.

10 per cent. or under ...

$12 \quad$,

20 ",

$40 \quad$,

60

\begin{tabular}{|c|c|}
\hline unde & $\ldots$ \\
\hline$\ldots$ & $\ldots$ \\
\hline$\ldots$ & .. \\
\hline $\begin{array}{l}\ldots \\
\text { over }\end{array}$ & \\
\hline
\end{tabular}

$\begin{array}{lll}\ldots & \ldots & \ldots \\ \ldots & \ldots & \ldots \\ \ldots & \ldots & \ldots \\ \ldots & \ldots & \ldots \\ \ldots & \ldots & \ldots\end{array}$

Percentage of profits payable to the Government.

$$
\text { Nil. }
$$

2.6 per cent.

12.9

37.5

50

Prior to 1916-17 the leasing of rights to mine on public diggings had yielded no revenue at all to the State. One lease had been granted and had been in operation for several years, but the Government had agreed to treat its share of the profits as a loan to the mining company until the annual profits should amount to $£ 250,000$, when its share of the profits in excess of that sum would become payable. This mark was reached in 1916 with the result that during the financial year 1916-17 the Govermment reeeived the sum of $£ 5,102$ as a first payment in respect of the lease. Subsequent to that date the growth in the receipts from this source has been extraordinary.

By the end of 1918 six additional leases had been granted under the aforementioned provisions, and by 1919 two of these were yielding a small revenue to the State. In respect of the remaining leases, the companies had not yet reached the producing stage.

In terms of the General Loans Consolidation Act of 1917, a proportion of the revenue derived from this source, representing taxation in aceordance with the Income Tax Consolidation Act of 1917, is to be assigned to the Revenue Account, and the remainder is to be placed to the credit of the Loan Account. ${ }^{i}$ This action on the part of the Government is highly commendable, being in entire accord with the fundamental principles of scientific finance.

$\checkmark$ Transvaal Act 35 of 1908, secs, 20 \& 23.

5 Act 30 of 1918. Ist Schedule.
6 Auditor-General's Report for 1919 $1920, \mathrm{p}, 97$.

${ }^{7}$ Act 22 of 1917 , sec. $3(d)$. 
The following table illustrates the remarkable growth in the revenue from the leasing of public diggings:

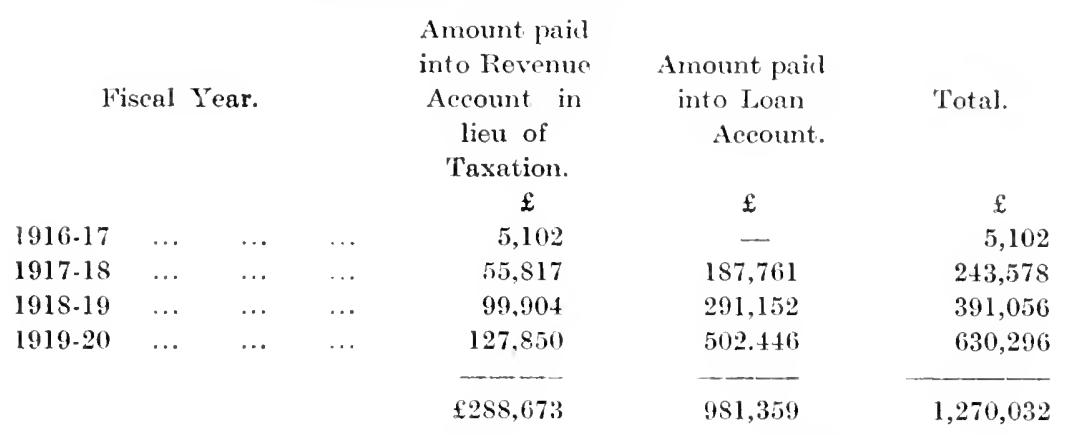

The great bulk of the reeipts referred to represents the Government's share of the profits in the "Govermment Gold Mining Areas (Modderfontein) Consolidated." The other gold mines subject to Government ownership were only in the initial stages of production, two of which had, however, begun to yield a small revenue, which will naturally tend to increase eonsiderably as the mines extend and produce a larger yield of gold and as the percentage of the Government's share of the profits inereases in aceordance with the sliding scale.

This method of leasing the right to mine on public diggings bids fair to become a very important source of revenue in the future. The Far East Rand, where the State owns a large number of undeveloped elaims, has reeently assumed a very important position in Witwatersiand mining, and it is from this distriet that a progressive output of gold may be looked for to take the place of the exhausted outerop properties of the Central Rand and to counteract the diminishing output of a large group of mines showing a serious reduction in values at depth. Recent ealculations show that, if only one-half of the state-owned claims on the East Rand which are not held by producing companies and whieh contain reef at a depth of less than 5,000 feet prove remunerative, after a deduction of 60 per cent. for non-payable zones, a yield of gold to the approximate value of $£ 450,000,000$ will be obtained.

Thus, if expectations are fulfilled and a transition takes place from the Central Rand to the Far East Rand, the Union Government will be in receipt of a considerable annual revenue from the leasing of gold mines on public land. 
(2) "Bewaarpluatsen." - Under the provisions of the Transvaal Precious and Base Metals Act of 1908, the right to mine for precious metals underneath any place reserved by former laws dealing with the mining of such metals is vested in the erown, and the Government is empowered to lease the right to mine under such areas on terms which it may deem most advantageous. ${ }^{9}$ The so-called "Bewarplaatsen Receipts" refer to the proceeds obtained by the Government from the leasing of the right to undermine such " bewaarplaatsen." i.e. storage sites, towns, villages, public squares, eemeteries, gardens, permanent fortifications, etc., which were reserved from pegging and prospecting and were situated on proclaimed land when the Act of 1908 came into effect.

The Government was direeted to assign the receipts from such leases to a separate fund or account until ownership thereto could be determined. This aecount was known as the Special Bewaarplaatsen Account, which was a speeial account within the Revenue Account. This complicated question was scttled by the Bewaarplaatsen Moneys Application Act of $191 \overline{7}$, which provided for the payment to the registered owner of the land upon which bewaarplaatsen were situated of nineteen-fortieths of the moneys received by the Government prior to the commencement of the Act, which went into effect in July, 1917, and of eighteen-fortieths of the moneys thereafter reeeived. The moneys received prior to the eommencement of the Act and available for distribution amounted to

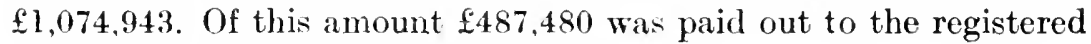
owners other than the State. ${ }^{10}$

In accordance with the provisions of the General Loans Consolidation Act of 1917, the greater part of the balance representing the Government's share was placer to the eredit of the Loan Aceount, a small portion thereof being payable to the Revenue Account. The sum due to the registered owners became a debt to be discharged by the issue of Union 5 per cent. stoek. ${ }^{11}$

Subsequent to 1917 the annual bewaarplaatsen receipts have been definitely allocated according to the terms of the act referred to, the Government's share being twenty-two-fortieths and the remaining eighteen-forticths being distributed amongst the registered owners of the land on which the bewaarplaatsen are situated. In the distribution of the latter amount the Government again comes into eonsideration, being the registered owner of several bewar-

\footnotetext{
9 (Transvaal) Act 35 of 1908 , sec. 52.

10 Report of Commissioner for Inland

11 Act 21 of 1917 , sec. 2 . Revenue, $1917-18$, p. 6
} 
plaatsen. Of the amount aecruing to the Government, the greater portion is assigned to the Loan Acconnt, as indicated in the following table."

Government's Shate of BewaArplatatsen Receipti, 1917-18 to 1919-20.

\section{Fiscal Year.}

$\begin{array}{ccccc}1917.18 & \ldots & \ldots & \ldots & \mathfrak{E} \\ 1918.19 & \ldots & \ldots & \ldots & -193 \\ 1919.20 & \ldots & \ldots & \ldots & - \\ & & & & \mathfrak{E} 44,193\end{array}$

Amount pairl
into Reveme
Account.

\begin{tabular}{cc} 
Amount paid & \\
into Loan & Total. \\
Ireonnt. & \\
$\mathfrak{E}$ & $\mathfrak{1}$ \\
50,532 & 124,725 \\
$118,965.5$ & 118,965 \\
128.021 & 128,021 \\
\hline $\mathfrak{E} 327.51 \mathrm{~s}$ & $£ 371,711$
\end{tabular}

This souree is expected to yield a steady revenue every year for the present and the near future, and, like the leases of gold mines on publie diggings, has great possibilities in the more remote future when the exhaustion of the oldest mines will probably occasion a more intensive demand for new mining lands.

(3) Base Metal Mines. - When base metals have been discovered in payable quantities on Crown land, the Government is empowered to lease to the discoverer the sole right of mining such base metals, subjeet to the payment of such rovalty and under such other conditions as may be agreed upon. ${ }^{13}$ Two base metal leases have been granted in this manner. The eonsideration for each lease is a percentage of the annual net profits, such payment being in addition to any taxation imposed by statute on the profits of mining.

The revenue derived from these base metal leases is comparatively small and has been very irregular in amount from year to year, depending on the vieissitudes of the eopper and tin-mining industries. as will appear from the following table. ${ }^{14}$

Revenue from Base Metal Leases.

\begin{tabular}{rccccc} 
Fiscal Year. & & & \multicolumn{2}{c}{$\begin{array}{c}\text { Amount. } \\
£\end{array}$} \\
& & & & & 16,540 \\
$1911-12 \ldots$ & $\ldots$ & $\ldots$ & $\ldots$ & $\ldots$ & 16,510 \\
$1913-14 \ldots$ & $\ldots$ & $\ldots$ & $\ldots$ & $\ldots$ & 5,619 \\
$1915-16 \ldots$ & $\ldots$ & $\ldots$ & $\ldots$ & $\ldots$ & 12,010 \\
$1917-18 \ldots$ & $\ldots$ & $\ldots$ & $\ldots$ & $\ldots$ & 26,662 \\
$1919-20 \ldots$ & $\ldots$ & $\ldots$ & $\ldots$ & $\ldots$ & 3,082
\end{tabular}

The receipts from the base metal leases are paid into the Revenue Account and so eonstitute an item of ordinary revenue.

\footnotetext{
12 Half-yearly Abstract of Union Statistics, June, 1919, p. 81 , and Finance 13 Transvaal Aet 35 of 1908 , sec. 119. Accounts. 1919-20. 14 O.Y.B. 1918 , p. 680 \& O.Y.B. 1921 .
} 
(c) Licences and Mynpacht Dues.-This revenue accrues under the provisions of the laws relating to prospecting and mining throughout the Union. Licences are required for the purpose of prospecting, or of working claims available for pegging by the public. Dues are also payable in respect of a "mynpacht," i.e., the portion reserved for the owner of the land or of the mineral rights. The licence fees and mynpacht dues are payable under the laws in force in the respective Colonies at the establishment of the Union, and thus vary considerably. In respect of private land, one-half of the licence moneys received by the Mining Commissioner is paid to the owner of such land.

The revenue derived from licences and mynpacht dues is fairly stationary, being subject to slight fluctuations only, as illustrated in the following table. ${ }^{15}$

Fiscal Year.

$\begin{array}{llll}1911.12 \ldots & \ldots & \ldots & . \\ 1913-14 \ldots & \ldots & \ldots & . \\ 1915-16 \ldots & \ldots & \ldots & . \\ 1917-18 \ldots & \ldots & \ldots & . \\ 1919-20- & \ldots & \ldots & .\end{array}$

Revenues from Licences and Mynpacht Dues.

$$
\mathfrak{E}
$$

.. 304,651

.. 274,473

.. 241,024

... 261,307

.. 274,867

This form of revenue is treated as ordinary revenue and paid into the Revenue Account. It has proved to be a factor of no small fiscal significance, and there is every likelihood of its continuing to yield a substantial revenue for a long period of time.

Summary.- The total revenue accruing to the Union Government from mining lands and rights has assumed immense proportions in recent years. In the year 1919-20 the Union Treasury received the sum of $£ 1,764,123$ from this source, whereas in 1913-14 the receipts had amounted to about $£ 850,000$. This great increase is indeed to be attributed in part to the prosperity prevailing in the mining industry at the time, but it also serves to indicate the natural trend of this branch of revenue and the enhancement of such revenue as a result of greater activity in regard to the leasing of mineral rights and mining lands belonging to the State.

The total revenue derived from the various items of the socalled "Government Ownership Mining Revenue" dluring the nineyear period from 1911-12 to 1919-20, both inclusive, amounted to $£ 8,038,956$, distributed as follows : 


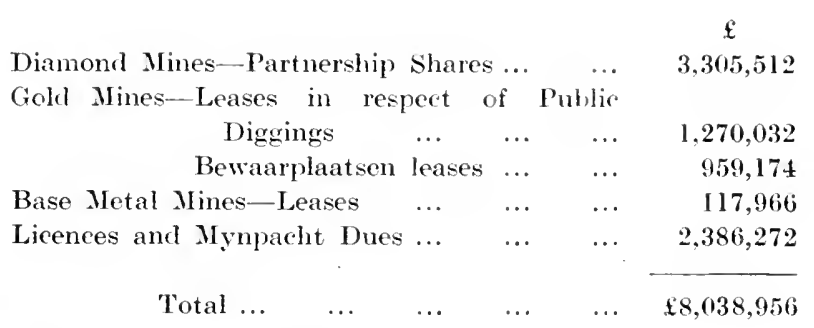

(2) Irrigation and Conservation of Water.

Prior to the establishment of the Union the principle of water conservation had been entirely ignored in colonial legislation, whereas in a country with large arid and semi-arid tracts this tormed the most essential factor of a water law. After the formation of the Union it was found impossible to frame a law approximating even remotely to an ideal water law, as consideration had to be given to the large vested interests which had aecrued during previous generations. The only solution was to adapt the old common law principles which had controlled the situation previously.

The Union Irrigation and Conservation of Water Act ${ }^{16}$ was passed in 1912. This Act fulfills a threefold purpose. In the first place, it is a national law regulating the use of water in public streams. Secondly, it provides special judicial machinery for dealing with the definition of water rights along public streams, the settlement of disputes, and the like. And finally, it contains a variety of provisions designed to promote the development of irrigation, such as the constitution of Irrigation Districts and Boards, and irrigation loans to private persons and Irrigation Boards.

The administration of the Irrigation Act is vested in a special department known as the Irrigation Department, which is a subdivision of the Department of Lands, under the control of the Director of Irrigation, who is assisted by a staff of engineers and other administrative officers. The functions of the Department of Irrigation may be briefly characterised as follows: $(a)$ to supervise, construct, and control irrigation works and to do all acts necessary or incidental to the conservation of the water resources of the Union; $(b)$ to examine and advise upon any seheme for the establishment or maintenance of irrigation works submitted to it by 
private individuals, river boards, irrigation boards, or local authorities; $(c)$ to advise as to the expediency of sanctioning and granting loans in connection with irrigation or water supply works. ${ }^{17}$

Government Irrigation Worls.-The Union Government is empowered to construct, subject to the approval of Parliament. any irrigation work which it considers necessary or desirable for the purpose of conserving or utilizing any public stream, or for abstracting, storing, or preventing the waste of subterranean water, and to supply and distribute, in accordance with regulation, water from any such works. The government is also empowered to assess rates (to be called Government rates) upon land irrigated or benefiting directly or indirectly by water from works constructed under its authority. ${ }^{18}$

Irrigation Loans.-The Union Irrigation Act contains elaborate provisions in respect of irrigation loans to individuals and irrigation boards. If an owner of land applies for a loan exceeding $£ 250$, the security offered therefor is to be a mortgage of immovable property. In the case of an irrigation board the security offered for a loan is to be the rates leviable by the board or such other security as may be approved by the Government. ${ }^{19}$

In fixing the period of the loan regard shall be had to the nature and probable durability of the works as determined by the Director of Irrigation. An irrigation loan repayable within a longer period than thirty years is not to be granted without the approval of Parliament, and an irrigation loan shall not, without the previous approval of Parliament, be granted in respect of any works if the total estimate of the cost thereof exceeds, when complete as an independent scheme, $£ 30,000 .{ }^{20}$

Capital Expenditure.-The capital expenditure in respect of irrigation in the Union of South Africa has been of considerable dimensions. During the decade from 1910 to 1920 the Union Government expended the sum of $£ 2,871,692$ on irrigation from loan funds, of which sum the greater proportion represented loans to irrigation boards and individuals in connection with irrigation projects approved of by the Director of Irrigation. In fact, the Irrigation Department is one of the most important organizations through which the Union Government assists in the development of the resources of the country.

17 Act 8 of 1912 , sec. 4 .

18 Ibid, sec. 7 .
19 Ibid, sec. 118.

20 Act 8 of 1912, sees, $119-120$. 
The following table ${ }^{21}$ serves to indicate the range of the expenditures from loan fund and the relative significance of the various items.

\begin{tabular}{|c|c|c|c|c|c|}
\hline Heading & $\begin{array}{c}1911 \cdot 12 . \\
\mathfrak{E}\end{array}$ & $\begin{array}{c}1913-14 \\
\mathfrak{E}\end{array}$ & $\begin{array}{c}1915-16 . \\
£\end{array}$ & $\begin{array}{c}1917-18 . \\
f\end{array}$ & $\begin{array}{c}1919-20 . \\
£\end{array}$ \\
\hline Government Schemes . & 29,605 & 36,061 & 34.527 & 141,367 & 128,415 \\
\hline Irrigation Loans & 76,900 & 186,074 & 198,735 & 224,908 & 295,674 \\
\hline Boring on Crown Land & 3,498 & 36,873 & 1,656 & 14,604 & 38,825 \\
\hline Purchase of Land & 71,401 & - & - & - & - \\
\hline Miscellaneous & 3,885 & 950 & - & - & - \\
\hline Total $\ldots$ & $£ 185,289$ & $\mathfrak{£ 2 5 9 , 9 5 8}$ & $£ 234,918$ & $\mathfrak{£ 3 8 0 , 8 7 9}$ & $£ 462,914$ \\
\hline
\end{tabular}

The most significant feature illustrated by the foregoing table is the extraordinary increase in the amount of the annual expenditures from loan funds, the year 1919-20 showing an increase of almost 150 per cent. over 1911-12.

Ordinary Expenditure on Irrigation and Water-boring.-The cost of departmental administration is comparatively small, taking into consideration the great variety of functions assigned to the Irrigation Department, such as the investigation of schemes for irrigation works and settlements, the consideration of applications for loans, the services of Government engineers in connection with irrigation projects, and water-boring for agricultural and stock farming purposes.

The following table ${ }^{22}$ shows the range of the ordinary expenditures on irrigation and water-boring which are defrayed from general revenue. The year 1915-16 represents the low mark of such expenditures as a result of the disturbance in revenue occasioned by the first years of the War and of the policy of economy necessitated thereby.

Ordinary Expenditure on IRrigation aNd Water-boring.

Head of Expenditure. 1911-12. 1913-14. 1915-16. 1917-18. 1919-20.

\begin{tabular}{|c|c|c|c|c|c|c|}
\hline & & $\mathfrak{£}$ & $\mathfrak{E}$ & $\mathfrak{E}$ & $\mathfrak{£}$ & $\mathfrak{f}$ \\
\hline Salaries and Wage & $\ldots$ & 26,842 & 37.747 & 33,303 & 38,536 & 48,149 \\
\hline Surveys ... & $\ldots$ & 17,215 & 19,019 & 7,246 & 21,042 & 25,785 \\
\hline \multicolumn{7}{|c|}{ Maintenance of Govern- } \\
\hline ment Works ... & .. & 3,700 & 2,453 & 7,131 & 7,397 & 2,054 \\
\hline Boring $\quad \ldots$ & $\ldots$ & 53.687 & 51,516 & 21,724 & 43,624 & 66,248 \\
\hline Miscellaneous & $\ldots$ & 15,510 & 21,165 & 10,363 & 18,239 & 27,524 \\
\hline Total ... & $\ldots$ & $£ 116,954$ & $£ 131,900$ & $£ 79,767$ & $£ 128,838$ & $£ 169,760$ \\
\hline
\end{tabular}

21 O.Y.B. 1919 , p. 506, \& Appropriation Accounts 1919-20, p. 363 .

22 O.Y.B. 1919. p. 853 \& Appropria. tion Accounts, $1919-20$, p. 322. 
The main reduction was made in the expenditure on boring operations, namely, from $£ 51,516$ in 1913 to $£ 21.724$ in 1915-16. Subsequent to $1915-16$ the expenditure was subject to sharp increases in view of the war bonus allowances, the increase in salaries and wages, the increased cost of materials, and the extension of the activities of the Irrigation Department. As a result of these factors the expenditure in 1919-20 showed an increase of almost 50 per cent. over that of 1911-12.

The greater part of these current expenditures represents a net financial loss to the Union Government, in view of the fact that only a small portion of such expenditures is covered by the departmental receipts from Government irrigation works, boring operations, sale of meteorological charts and meteorological and hydrographic data, etc. In 1916-17, for example, the current expenditure on irrigation and boring amounted to $£ 87,352$, whereas the departmental receipts yielded only $£ 21,901$, i.e. about one-fourth of the expenditure. Of the latter amount, $£ 15,231$ represented revenue derived from boring operations, such revenue being of the nature of a payment for services rendered, and $£ 3,883$ was derived from the Government irrigation works. ${ }^{23}$

With regard to boring, the annual loss cluring the latter part of the decade tended to increase as a result of the rise in the cost of boring.

Heading.

Cost of Boring (exclusive of certain adminis.

trative charges) $\quad \ldots \quad \ldots \quad \ldots \quad \ldots$

Charges raised $\ldots \quad \ldots \quad \ldots \quad \ldots \quad \ldots$

Loss $\quad \ldots \quad \ldots \quad \ldots \quad \ldots \quad \ldots$
1917-18. 1918.19. 1919-20.

$\mathfrak{f} \quad \mathfrak{f} \quad \mathfrak{E}$

The Government bears not only the loss between the tariff charge

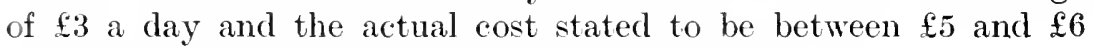
a day, but also the loss on unsuccessful boring. ${ }^{24}$ p

The receipts from Government irrigation works do not by any means represent an adequate return on the capital investment. This is to be attributed to the absence of the fiscal motive in the construction of the Government works, the main aim being to construct such irrigation works as are considered to be necessary or desirable for the purpose of conserving water. These works may prove to be self-supporting or even profitable, but there is every likelihood of their being a losing proposition for a long period of

23 Report of Commissioner of Inland 24 Report of Auditor-General for 1919. Revenue for $191617, \mathrm{p} .28$. 1920 . 1. 327. 
time. After the construction of such works the Government does make every effort to encourage the more extensive use of the water for irrigation purposes and to facilitate the formation or irrigation settlements, but frequently the cost of construction is so great that the rates will be excessive if levied with the intention of making the undertaking self-supporting. However, the burden imposed on the taxpayer is justified by the aims of the Government.

Interest on Irrigation Loans.-Every attempt is made to render the investment in respect of irrigation loans a self-supporting governmental activity. The Union Irrigation Act of 1912 contains a variety of provisions designed to preclude the possibility of such investment becoming a burden on the taxpayer. The Minister of Finance is even empowered to levy and recover rates and to collect any dues payable to an irrigation board, in the event of such a board failing to pay any moneys due from it to the Government in respect of a loan. The rate of interest payable on such loans was fixed at $3 \frac{3}{4}$ per cent. ${ }^{25}$ by the above act, representing the current rate of interest on government loans at the time. When, however, the European War occasioned a rise in the rate of interest, an amending act $^{26}$ was passed by Parliament in 1916 providing for changes in the rate of interest on irrigation loans, such changes to be notified in the Government Gazette by the Minister of Finance. Subsequent to that date the rate of interest on such loans has been 5 per cent., which amply covers the moneys issued from the Treasury in respect of irrigation loans, but which does not provide for the cost of administration, including the cost of investigating the proposed schemes.

In view of the fact that the Union Government assumes a risk in its role as money-lender and uses its credit in order to raise the funds for irrigation loans, it is entitled to derive some benefit from the irrigation works after the loans have been redeemed. The activity of the Government in respect of irrigation is one of national interest, and it is not fair to other localities if the State receives no additional compensation for the special benefits conferred on certain regions. It would seem advisable, then, for the Government to levy a low rate on the irrigation works of boards after redemption of the loans.

Prior to 1919-20 the loss sustained by the Treasury on account of certain amounts being written off as irrecoverable was slight. In 1917-18 the amount written off was $\mathfrak{£ 2}$, and in 1918-19 there was no occasion for any such action. In 1919, however, a special act ${ }^{27}$ 
was passed by Parliament with a view to providing for the writing off of an amount of $\mathfrak{E} 19,560$ in respect of loans to three irrigation boards, whose works suffered a great deal of damage during the flood in those regions in $1916 .^{28}$ The basis on which the remission of moneys due to public funds was fixed was to remit the proportionate capital cost under the original scheme of such land as had actually becn destroyed, plus 33 per cent. of the expenditure necessitated by the flood.

Summary.-It is apparent, therefore, that the promotion of the development of irrigation in all its aspects in South Africa has been secured by the Union Government at no slight expense to the taxpayer. The amount of the annual expenditure on irrigation and boring to be defrayed by taxation depends on the following factors : the cost of departmental administration, the loss incurred in connection with the boring operations of the department, the amount by which the interest on the capital investment of the Government irrigation works exceeds the income from those works, and the loss which may arise from the non-payment of interest due and from the remission of interest payable on such amounts as are written off as irrecoverable.

However, the results likely to be obtained in the future from the irrigation policy of the Union Goverrment, the essence of which is the conservation of water and the promotion of irrigation by means of irrigation loans extending over a period of 40 or 50 years at the rate of 5 per cent. under present conditions, amply justify the imposition on the taxpayer of the burden referred to. In fact, the only regret is that the Colonial Governments had not handled the irrigation problem with such vigour and determination as the Union Government has.

(3) Guano, Penguin Eggs, and Seal Skins.

The collection and distribution of guano and other products located on the Government Islands are vested in the Office of the Guano Islands, which is a sub-division of the Union Department of Agriculture, under the control and management of the Superintendent of the Government Guano Islands. The Government Guano Islands comprise all the principal islands, islets, rocks, and reefs situated along and round the western and southern portions of the South African coast. These islands are being worked mainly for the production of guano, but other products, such as penguin eggs, seal skins, seal oil, etc., are also obtained. 
Guano is sold in a pulverized form, and is used mainly in the cultivation of cereals and vegetables. Its principal chemical conftituents are nitrogen, potash, phosphorie oxide, and lime. The main objeets aimed at, in the working of the Guano Islands as a Government undertaking, is to assist the farmers in proeuring a first-class fertilizer at reasonable cost, and thus the guano is sold at a price fixed by the Goverument, very much below its commercial value. Prior to the War the price of guano was $\mathfrak{E 5}$ per ton. In 1915

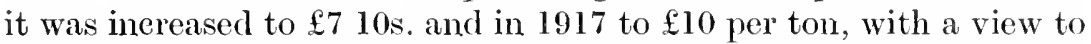
meeting the increased cost of production and also to placing some check upon the great seramble for the product at the low figure.

Financial Results.-The guano business has proved to be a profitable enterprise for the Union Government, yielding a substantial net profit every year. The following table shows the receipts, expenditures, and net profit over a period of years.

\begin{tabular}{|c|c|c|c|c|c|c|c|}
\hline \multicolumn{3}{|c|}{ Heading. } & 1911-12. & 1913.14 & $1915-16$ & $1917-18$ & $1919-20$. \\
\hline eceints & • & $\ldots$ & 39,490 & 42,771 & 74,911 & 82,584 & 291,994 \\
\hline Expenditure & & $\ldots$ & 26,474 & 33,539 & 31,916 & 44,424 & 63.538 \\
\hline et Profit & $\cdots$ & $\cdots$ & $£ 13,016$ & $£ 9,232$ & $\mathfrak{f} 42,995$ & $£ 38,160$ & $\varepsilon 228,45 t$ \\
\hline
\end{tabular}

The extraordinary inerease in the receipts for 1919-20 is to be attributed entirely to the phenomenal prices of seal skins during that year, an amount of $\mathfrak{\$ 1 9 3 , 5 7 5}$ having been realised from the sales in London of seal skins secured from the Government Guano Islands. The price had advanced from an average of $37 \mathrm{~s}$. 6d. per

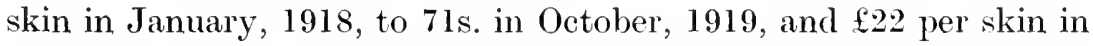
January, 1920. The high prices realised in January, 1920, were regarded by the South African Trades Commissioner as phenomenal, and were attributed by him to foreign competition engineered with a view to capturing the seal-skin trade. ${ }^{29}$

With regard to the expenditures, the increase is mainly due to the extension of the war bonus in 1918 and to the general increase in salaries and wages authorised in 1919, and to the increased eost of supplies.

The guano business is an enterprise in respect of which the capital expenditure is comparatively small, the capital account as on

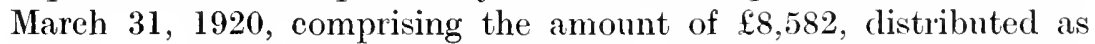
follows: general plant, $\mathfrak{1 , 4 0 2}$; houses, pier's and other structures,

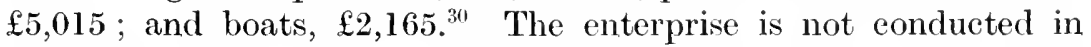
aecordance with strict commereial principles, no provision being 
made for the payment of interest on the capital investment, which, however, is such an insignificant item that it does not appreciably affect the situation. Taking the rate of interest to be $4 \frac{1}{2}$ per cent.,

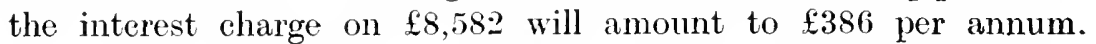
The depreciation charge represents a fairly large percentage of the total capital investment, namely 10 per cent., the amount assigned to depreciation in 1919-20 being $£ 825 .^{31}$

As a result, then, of the favourable conditions attending the conduct of the guano enterprise, it has been a source of net revenue to the Union Government. 


\title{
3. INVESTMENT.
}

\author{
CHAPTER 5.
}

Investment of Cash Balances and Deposits.

\section{(a) Investment of Cash Balances.}

The Union Treasury is entrusted with the temporary investment of cash balances, which is interpreted in the Exchequer and Audit Act of 1911 as meaning "the placing of moneys on deposit at interest with any banking institution at eall or subject to notice not exceeding twelve months." "With a view to economising the public balances, the Treasury is directed to restrict the sums to be issued or transferred from time to time to the credit of accounting officers, to such total sums as the Treasury may consider necessary for conducting the current payments for the public service assigned to accounting officers. ${ }^{2}$

The revenue derived from this source varies considerably from year to year, depending on the amount of the balances available for investment. The interest on the cash balances generally ranges from $£ 75,000$ to $£ 100,000$ per annum, the amount in $1916-17$ being $£ 82,219 .^{3}$

(b) Investment of Deposits.

The investment of all trust funds or deposit moneys coming into the hands of the Government-such as post office savings bank moneys, guardians' funds, pension funds-is assigned to the Public Debt Commissioners, subject to the retention at the disposal of the officers who have the control, management or administration of any deposits of such reasonable working balances as may be approved by the Minister of Finance. Any profit earned by the Commissioners in connection with their transactions in any financial year is to be payable to the Consolidated Revenue Fund, and any loss incurred by them is to be ehargeable on that fund. ${ }^{*}$

This practice, however, has been followed consistently in the case of the Guardians' Funds only, the surplus income from the investment of Savings Bank moneys being placed in a reserve fund

1 Act 21 of 1911, sec. $28(a)$.

2 Ibid, sec. 22 (2).
3 Report of Commissioner for In!and Revenue 1916-17, p. 27.

4 Act 18 of 1911 , sec. 9-13. 
which was created to provide against depreciation, and any profit realized on investments in respect of pension or other funds being credited to such funds, or any loss incurred being borne by such funds.

The surplus interest earned in connection with the investment of the guardians' funds, and paid into the Revenue Account, was subject to appreciable fluctuation, ranging from $£ 38,854^{5}$ in $1916-17$ to $£ 51,926^{6}$ in $1919-20$.

Thus, the revenue from investment varies from about $£ 120,000$ to $£ 150,000$ per annum.

5 Report of Commissioner for Inland Revenue, $1916 \cdot 17$, p. 27.
${ }^{6}$ Report of Public Debt Commis* sioners $1919 \cdot 20$, p. 31 . 


\title{
B. ADMINISTRATIVE REVENUE.
}

\author{
CHAPTER 6.
}

\section{Fees. Departmental Receipts. Fines and Forfeitures. Miscellaneous Revenue.}

(1) Fees.

(a) Fees of Office or Court.-These fees are prescribed by law, regulation, or rule of court in respect of proceedings or documents used in any court of law, or in respect of transactions performed or documents used in any public office. They are regarded as payments for services rendered.

The payment of such fees is to be denoted by means of adhesive revenue stamps of the required value affixed to the documents chargeable or by means of impressed or embossed stamps.

The following table ${ }^{1}$ shows the collections in respect of fees of office or court and the heads of the various government departments and offices in which such fees are collected.

\begin{tabular}{|c|c|c|c|c|}
\hline Heading. & $\begin{array}{c}1912.13 \\
£\end{array}$ & $\begin{array}{c}1914-15 . \\
f\end{array}$ & $\begin{array}{c}1916 \cdot 17 \\
\mathfrak{f}\end{array}$ & $\underset{f}{1917.18}$ \\
\hline Masters of Supreme Court & 27,902 & 27,131 & 33,736 & 34,812 \\
\hline Registrars of Superior Courts ... & 14,547 & 11,688 & 11,443 & 8,774 \\
\hline Registrars of Deeds & 48,623 & 29,302 & 48,858 & 52,18 \\
\hline Registrars of Patents & 14,073 & 10,472 & 9,158 & 14,5 \\
\hline Registrars-General of Births, Mar- & & & & \\
\hline $\begin{array}{l}\text { riages, and Deaths } \\
\text { Sheriffs } \quad \ldots \quad \ldots\end{array}$ & $\begin{array}{l}7,058 \\
1,493\end{array}$ & $\begin{array}{r}7,148 \\
623\end{array}$ & $\begin{array}{l}7,821 \\
1,010\end{array}$ & $\begin{array}{l}9,438 \\
2,768\end{array}$ \\
\hline Surveyors-General ... & 6,904 & 5,291 & 6,249 & 8,30 \\
\hline $\begin{array}{cccc}\text { Magistrates and } & \text { District } & \text { Officers } \\
\text { (estimated) } & \ldots & \ldots & \ldots\end{array}$ & 40,000 & 40,000 & 40,000 & 40,000 \\
\hline Total ... & $£ 160,600$ & $£ 131,655$ & $£ 158,275$ & $£ 170,7$ \\
\hline
\end{tabular}

(b) School and Hospital Fees.-In the Cape of Good Hope local school administration is conducted by school boards, which have the general financial control of schools under their jurisdiction. The expenditure on school education is defrayed from grants-in-aid made by the Provincial Council supplemented by local sources of revenue. Contributions from local sources are derived almost

1 Reports of Commissioner for Inland Revenue for 1916-17 and 1917-18, pp. 10 and 7 respectively. 
entirely from school fees. These fees are not paid into the Provincial Revenue Fund, but are retained by the school boards and, together with the provincial grants-in-aid, applied toward the payment of school expenditures. Thus, in the Cape Province, school fees do not constitute an item of provincial revenue. In 1916 the amount received as school fees by school boards in this province was $£ 258,289,{ }^{2}$ or more than 25 per cent. of the total school expenditure.

In Natal and the Orange Free State, where school fees are also in force, the receipts are paid into the Provincial.Revenue Fund and all school expenditures paid out of that fund. In the Transvaal school fees have been abolished and both primary and secondary education rendered free, while books and school materials are provided by the Provincial Administration. This change was brought about in 1914, involving the loss of provincial revenue to the extent of about $£ 30,000$ per annum.

In respect of hospitals the same condition prevails. In some provinces hospital fees constitute an item of provincial revenue, such as in Natal and the Transvaal, whereas in the Cape of Good Hope and the Orange Free State it is not the ease. In Natal four hospitals are under the direct control of the Provincial Administration and in Transvaal nine are maintained by the Province. The fees charged in these hospitals are paid into the revenue funds of those provinces. In the Cape Province and the Orange Free State, on the other hand, the management of hospitals, as well as the full financial responsibility, is vested in hospital boards which are financed by provincial subsidies calculated on the amount of their revenue derived from patients' fees and voluntary contributions and bequests.

The following table ${ }^{3}$ shows the amount of those school and hospital fees which are paid into the revenue funds of the Provinces concerned and so represent provincial revenue.

Revenue from Hospital
Fiscal Year.

$\begin{array}{cccccc} & & & & & \\ 1913.14 & \ldots & \ldots & \ldots & \ldots & 1 \\ 1914-15 & \ldots & \ldots & \ldots & \ldots & 114,030 \\ 1915-16 & \ldots & \ldots & \ldots & \ldots & 104,874 \\ 1916.17 & \ldots & \ldots & \ldots & \ldots & 110,172 \\ 1917-18 & \ldots & \ldots & \ldots & \ldots & 117,874 \\ 19 & & & & 151,428\end{array}$

2 O.Y.B. 1918, p. 261.

3 Half-yearly Abstract of Union Statistics, June 1919, p. 81. 
Heading.

SUMMARY :

1913-14. 1915-16. 1917-18.

$\mathfrak{f}$

Revenue from Fees $\quad \ldots \quad$...
Percentage of Gross Ordinary Revenue (Union

Percentage of Gross Ordinary Revenue (Union
and Provincial) $245,685 \quad 248,590 \quad 322,215$

Per Capita of European Population $\quad \ldots \quad$...

$\begin{array}{lll}1.4 & 1.4 & 1.5\end{array}$

3s. 8 d. 3s. $7 \mathrm{~d}$. $4 \mathrm{~s} .6 \mathrm{dl}$.

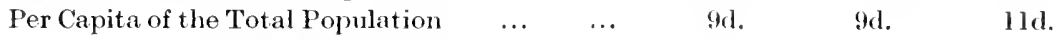

\section{(2) Departmental Receipts.}

These receipts accrue to the various government departments either in the form of payments for services rendered, such as police services, prison labour services, or printing services to the Railway and Harbour Administration and the general public, or in the form of income from public estate, such as the receipts from the agricultural experimental farms, or in the form of receipts from the sale of government stores and equipment.

The revenue from this source varies considerably from ycar to year, as shown in the following table.

\begin{tabular}{|c|c|c|c|c|c|}
\hline Heading & $\begin{array}{l}1911 \cdot 12 \\
\mathfrak{f}\end{array}$ & $\begin{array}{c}1913 \cdot 14 . \\
\mathfrak{f}\end{array}$ & $\begin{array}{c}1915-16 . \\
£\end{array}$ & $\begin{array}{l}1917.18 . \\
£\end{array}$ & $\begin{array}{c}1919 \cdot 20 . \\
£\end{array}$ \\
\hline Departmental Receipts ${ }^{4}$ & 555,425 & 390,929 & 367,885 & 437,045 & 522,043 \\
\hline $\begin{array}{l}\text { Percentage of total Ordin- } \\
\text { ary Revenue (Union } \\
\text { and Provincial) }\end{array}$ & 3.9 & 2.3 & 2.1 & 2 & 1.7 \\
\hline $\begin{array}{c}\text { Per Capita of European } \\
\text { Population } \ldots \\
\text { Per Capita of Total Popu- }\end{array}$ & $8 s .8 \mathrm{~d}$. & 5s. $10 \mathrm{~d}$. & 5s. $3 \mathrm{~d}$. & 6s. $1 \mathrm{~d}$. & $7 \mathrm{~s} . \quad 1 \mathrm{~d}$. \\
\hline lation $\ldots \quad \ldots \quad \ldots$ & 1s. $10 \mathrm{~d}$. & 1s. $3 \mathrm{~d}$. & ls. $\quad 1 \frac{1}{2} \mathrm{~d}$. & ls. $3 \mathrm{~d}$. & ls. $6 \mathrm{~d}$. \\
\hline
\end{tabular}

(3) Fines and Forfeitures.

The revenue from fines and forfeitures is likewise an item of revenue that is subject to considerable fluctuations.

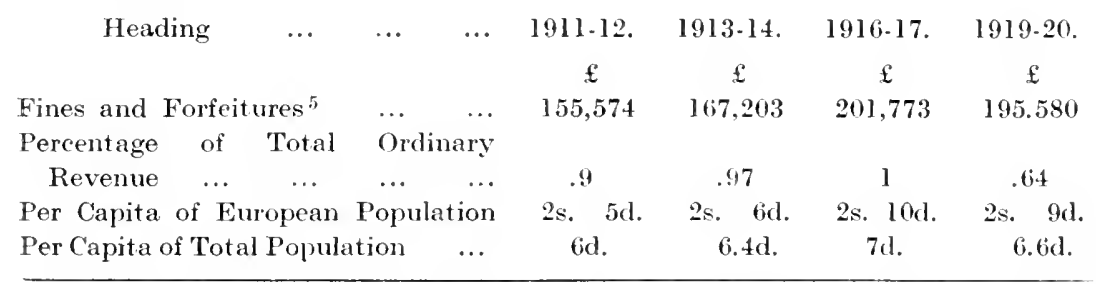

4 O.Y.B. 1919, p. 834 , and Auditor-
General's Report for $1919-20$, p. 88 .
(The departmental receipts do not
include the receipts from the Govern- ment Guano Islands which are treated under commercial revenues.)

5 O.Y.B. 1919 , p. 834, and AuditorGeneral's Report for 1919-20. p. 88. 
(4) Rents of Government Houses and Buildings.

This revenue is included under the general head "Rents of Government Property " along with the rentals from Crown Lands payable by European settlers and native squatters. The average annual revenue from the rents of Government houses and buildings is about $£ 50,000$, the amount in $1916-17$ being $£ 49,281 .^{6}$

(5) Miscellaneous Revenue.

Heading.

Miscellaneous Revenue

Percentage of Total Ordinary

Revenue $\ldots$...
1911-12. 1913-14. 1916-17. 1919-20.

$\begin{array}{cccc}\mathfrak{1} & \mathfrak{1} & \mathfrak{1} & \mathfrak{f} \\ 87,739 & 175,207 & 65,202 & 84,877^{\circ}\end{array}$

$\begin{array}{lll}1.09 & 1 & .33\end{array}$

.28 


\title{
C. REVENUE FROM tAXATION.
}

\author{
CHAPTER 7.
}

\section{Customs Duties.}

Introductory.-In 1903 the South African Customs Union was formed, comprising the following territories: Cape Colony, Natal, Transvaal, Orange River Colony, Rhodesia, Bechuanaland Protectorate, Basutoland, and Swaziland. The establishment of this customs union was the result of a Convention concluded between the territories named.

Since the establishment of the legislative Union of the four self-governing British Colonies in South Africa in 1910, the statistical bureau created by the parties to the Customs Union has been merged into the Union Department of Customs and Excise.

Upon the constitution of the first Ministry of the Union, a portfolio of Commerce and Industries was instituted which provided for the control of customs and excise, and also of inclustrial and commercial matters. On a rearrangement of portfolios, the Department of Commerce and Industries was abolished, ministerial control of customs and excise being vested in the Department of Finance; so that the Customs Department is now a sub-department of the Department of Finance.

The Customs Union Convention terminated on June 30, 1910, and customs agreements were concluded between the Union of South Africa and the neighbouring territorities included in the former Customs Union, whereby a free interchange of South African products and manufactures was secured and an equitable share of the duties collected on goods passing through the Union of South Africa to those territories was to be paid over to them, and vice versa.

Customs Administration in the Union of South Africa.-The administration of the Customs of the Union of South Africa is provided for by the Customs Management Act which became operative in August, 1913, in substitution for numerous laws previously in force in the various provinces. The control and management of the collection of duties, and of the officers and persons employed in the Customs Department, is vested in a Commissioner of Customs."

\footnotetext{
1 S.A. Year Book, 1914, pp. 276-280.
}

$$
2 \text { Act } 9 \text { of 19I3, sec. I. }
$$


Definition of Value.-The Customs Tariff Act of 1914 specifies the procedure to be adopted in respect of valuation. For the purpose of estimating the amount of customs duty whenever levied on goods ad valorem and for the purpose of declarations and oaths which may at any time be required by law or regulation in relation to such duty, the value of those goods shall be taken to be the true current value for home consumption in the principal markets of the country from which the goods were imported at the time of importation, including the cost of transportation to the port of shipment and the cost of packing, but not including agents' commission when such commission does not exceed 5 per cent.; provided that in no case shall the value for purposes of duty be less than the cost of the goods to the importer at the port of shipment. Whenever goods are imported into the Union under such circumstances or conditions as render it difficult to determine the value thereof for purposes of duty, the Commissioner of Customs is to estimate the value of such goods. ${ }^{3}$

Tariff System of the Union.-The tariff system of the Union is formulated in the Customs Tariff Act of 1914, in accordance with which the customs duties are divided into specific and " ad valorem " duties, the latter being again subdivided into three groups, namely, the 25 per cent. ad valoreni rate, the 3 per cent. ad valorem rate, and the general ad valorem rate of 15 per cent., which, however, was increased to 20 per cent. by the Customs Amendment Act of 1915 in view of the shrinkage in revenue occasioned by the outbreak of the European War and the South African Rebellion. The general ad valorem rate applies to all goods, wares, and merchandise not specified under other headings or enumerated in the free list.

As articles of merchandise subject to the 25 per cent. ad valorem rate may be mentioned the following: leather manufactures, blankets, sheets, rugs, jewellery, harness and saddlery, light beverages, gold and silver plate, tobacconists' wares, perfumery, phonographs, gramophones and records. With regard to the 3 per cent. ad valorem rate the following items may be enumerated: machinery, apparatus, appliances, and implements for agricultural, manufacturing, mining, bookbinding, printing, and other industrial purposes; bookbinders' requisites: railway, telegraph, and telephone requisites, bolts, rivets, screws. and nails, ambulance materials, unmanufactured wood; wire; disinfectants; leather; bottles and jars of common glass and earthenware. ${ }^{4}$ 
In respect of the specific duties, the great bulk of articles relate to the varieties of food, drinks, and tobacco. As foodstuffs of animal origin may be mentioned: butter, $2 \frac{1}{4} \mathrm{~d}$. per 1b. ; eggs, ld. per lb. ; fish, $1 \frac{1}{4} \mathrm{~d}$. per lb. ; meat products, $1 \frac{1}{4} \mathrm{~d}$. per 1b. : cream, 5s. 2d. per $100 \mathrm{lb}$.; and as foodstuffs of vegetable origin: wheat, 1s. 2d. per $100 \mathrm{lb}$.; flour, 2s. 6d. per $100 \mathrm{lb}$.; rice, 1s. Od. per $100 \mathrm{lb}$. ; confectionery, $2 \frac{1}{2} \mathrm{~d}$. per $\mathrm{lb}$. ; butter and margarine, $3 \frac{1}{4} \mathrm{~d}$. per lb. ; potatoes, 2s. od. per $100 \mathrm{lb}$. ; fruit canned or dried, $2 \frac{1}{4} \mathrm{~d}$. per lb. ; onions, $\frac{1}{2} \mathrm{~d}$. per $1 \mathrm{~b}$.

With regard to spirits and alcoholic liquors the rates in 1919 were as follows: ale, beer and cider, 2s. 9d. per imperial gallon; perfumed spirits, $£ 11 \mathrm{ls}$. $6 \mathrm{~d}$. per gallon (and in addition 10 per cent. ad

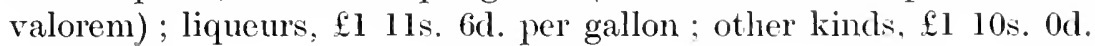
per gallon.

On tobacco and tobacco products the duties were as follows: prepared tobacco, 4s. per lb. ; umprepared tobacco, 3s. 6d. per lb.; cigars, 6s. per 1b. ; and cigarettes, 5s. per lb., In the case of cigars and cigarettes there is an additional duty of 15 per cent. ad valorem. ${ }^{5}$

In normal times the revenue derived from the specific duties was of about the same amount as that from the "ad valorem"

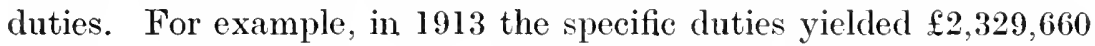

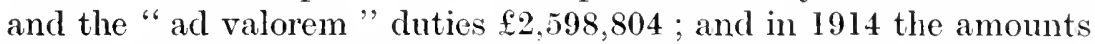
were $£ 2,016,599$ and $£ 2,064,545$ respectively. By 1918 , however, the situation was entirely changed, the revenue from specific duties

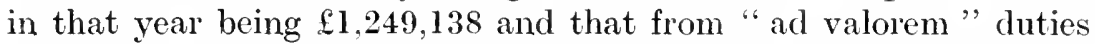

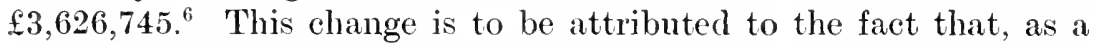
result of war conditions, the importation of those articles of merchandise which are subject to specific duties, such as foodstuffs, drinks, and tobacco, was restricted to a considerable extent; and the increase in the yield of "ad valorem " duties is due to the enhanced value of goods.

Of the articles enumerated in the free list the following are the most important : uniforms for military, naval, or other forces of His Majesty whether Imperial, Union or Colonial ; bags ; atlases, charts, globes and maps; books and music ; dyes for manufacturing purposes and tanning substances for leather; surgical instruments and appliances; church decorations; bullion, coin, and specie ; nitrates and guano. ${ }^{\top}$

Preferential Rates.-In 1903 under the Customs Union Convention concluded between the British Colonies and territories in South 
Africa, it was agreed to grant a rebate of certain percentages of customs duties on any goods and articles produced or manufactured in the United Kingdom and imported into those colonies and territories, and also on goods and articles produced and manufactured in those British colonies, protectorates, and possessions which granted equivalent reciprocal privileges. Rebates of duty were continued in subsequent Conventions and have been continued since the constitution of the Union in favour of the United Kingdom and those British dominions which have afforded reciprocal treatment.

Under the Customs Tariff Act of 1914, a rebate of 3 per cent. was allowed in favour of the United Kingdom and reciprocating British dominions in the case of "ad valorem " duties $;{ }^{8}$ so that in the case of the goods subject to the 3 per cent. ad valorem rate a rebate of the whole of the duty is granted on British merchandise. In respeet of the specific duties the rebate varies considerably, ranging from 10 per cent. of the duty as in the case of flour, where the duty is $2 \mathrm{~s} .6 \mathrm{~d}$. per $100 \mathrm{lb}$. and the rebate $3 \mathrm{~d}$., to 20 per cent. of the duty in the case of fish and meat products, where the duty is $1 \frac{1}{4} \mathrm{~d}$. per lb. and the rebate $\frac{1}{4} \mathrm{~d} .^{9}$

On an average, the rebates amount to about 2.8 per cent. of the value of the imports from Great Britain and the reciprocating British dominions, namely, Canada, Australia, and New Zealand. In 1913 the value of British goods imported into the Union and subject to rebate was $£ 22,494.415$, and the amount of the rebate $£ 628,935$; and in 1918 the corresponding figures were $£ 25,158,773$ and $£ 698,231 .^{10}$ The relation of the rebate to the total customs revenue varies from year to year in accordance with changes in the relation of the value of quantity of imports from Great Britain and the reciprocating dominions to the value or quantity of the total imports into the Union. The average ratio of rebates to the total customs receipts (including the amount rebated) is about 12 per cent. In 1913 it was 11.3 per cent., and in 191812.5 per cent. Thus, the policy of Imperial preference involves a remission of customs revenue to the extent of about 12 per cent. or to an amount of about $£ 650,000$ per year.

Customs Revenue.-As a result of abnormal conditions during the greater part of the decade from 1910 to 1920 , the customs revenue of the Union was subject to considerable fluctuations. The fluctua-

8 Act 26 of 1914. secs. 3 and 4.

10 O.Y.B. 1919, P. 734.

9 Schedule to Act 24 of 1916 . 
tions were not so marked in respect of the total customs receipts as in respect of the constituent items.

The following table ${ }^{11}$ serves to illustrate the changes brought about in the yield of the various items by the war disturbances:

Article of Import.

\begin{tabular}{cc}
1913. & \multicolumn{1}{c}{1918.} \\
$\mathfrak{f}$ & $\mathfrak{f}$ \\
258,874 & 22,900 \\
$1,003,544$ & 456,833 \\
745,345 & 469,962 \\
342,624 & 459,802 \\
213,574 & 97,500 \\
425,971 & $1,600,170$ \\
138,807 & 151,017 \\
110,058 & 119,731
\end{tabular}

The great decrease in the customs receipts in respect of foodstuffs, spirits and alcoholic liquors, and tobacco, is to be attributed to the restriction of the importation of those articles into the Union. The decrease is most marked in the case of foodstuffs, mainly as a result of the increased demand for such articles in the belligerent countries, but to a lesser extent also in consequence of the limited shipping accommodation available.

On the other hand, the increase in the customs revenue from clothing and fabrics is to be attributed to the greatly enhanced value of such articles, and to the continued importation thereof in about the same quantity as before the War in view of the lack of facilities for the extensive manufacture of textiles in the Union, whereas in the case of foodstuffs, drinks and tobacco the domestic production was capable of extension in accordance with the demand for domestic products, the higher cost of ocean transportation and of insurance serving as means of protection to domestic industries.

The fluctuations in the total customs receipts, as indicated in the following statement, ${ }^{12}$ were due to the operation of several factors.

Fiscal Iear.

$\begin{array}{cccc}1912-13 & \ldots & \ldots & \ldots \\ 1914-15 & \ldots & \ldots & \ldots \\ 1916-17 & \ldots & \ldots & \ldots \\ 1918-19 & \ldots & \ldots & \ldots \\ 1919-20 & \ldots & \ldots & \ldots\end{array}$

Net Customs Receipts. $£$

$$
4,634,929
$$

$3,690,531$

$5,237,530$

$5,991,733$

$6,288,524$

In the first place, the decline in the year 1914-15 is che to the violent disturbance in trade occasioned by the outbreak of the

11 Ibid, pp. 834 and 737 . 
European War and of the South African Rebellion during the last quarter of 1914. In 1913-14 the customs revenue amounted to $\{4,733,171$, so that the customs receipts for 1914-15 showed a decline of about 22 per cent as compared with the preceding year.

As a result of the decline in customs receipts during the first year of the War, legislation was introduced in 1915 with a view to increasing the customs duties on certain articles of general consumption, such as ale, beer, cider, coffee, tea, sugar, boots and shoes, the increase on an average being about 30 per cent.

In addition, the general ad valorem rate was increased from 15 to 20 per cent.

In 1915-16 the customs revenue amounted to $£ 4,744,691$, which represents the normal revenue from that source. The increase of about 28 per cent. over the preceding year is to be ascribed mainly to the increases in duties, and to a lesser extent to the increase in the value of the goods subject to "ad valorem" duties and to the revival of trade. In view, however, of the fact that additional revenue was needed, further increases were made in 1916, namely, in respect of mineral oils and spirits, to the extent of about 10 per cent.

In 1916-17 the customs receipts amounted to $£ 5,237,530$-an increase of about 10 per cent. over the preceding year. This increase is due mainly to the enhanced value of imported goods. The increases in specific duties did not yield much additional revenue, since the importation of those articles which were subject to specific duties had been checked somewhat by war conditions.

In 1917 the increases in the duties on mineral oils, coffee, and on tea in large tins or containers were removed, and the increase in the duty on tea in small tins was partially reduced, namely, from 7 d. to $6 \mathrm{~d}$. per $1 \mathrm{~b}$., the normal duty being $5 \mathrm{~d}$. per $1 b^{13}$

The customs receipts showed a decline of about 12 per cent. in 1917-18 as compared with the preceding year. This decline is due mainly to the diminution of the import trade during that year, but partly also to the reduction made in 1917. By 1918 the importation of foodstuffs and drinks had fallen off to a considerable extent. In that year the value of foodstuffs and drinks imported into the Union amounted to $£ 4,722,118$, in contrast with $£ 7,584,290$ in $1913 .{ }^{14}$ This contrast is more striking when one takes into consideration the great difference in prices in the two years.

After the middle of 1918 , however, there was a revival of trade, and this factor coupled with the further increase in the value of goods in general greatly enhanced the yield of the "ad valorem" duties. 
In that year the "ad valorem" duties yielded $£ 3,626,745$, as

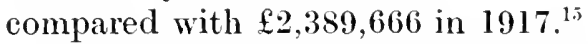

On the other hand, the yield of the specific duties decreased considerably on account of the great decline in the importation of articles subject thereto, such as foodstuffs and drinks. In 1918 the

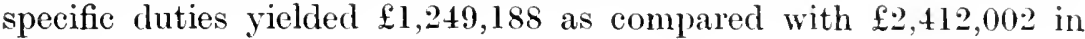
$1917^{16}$

The enhanced value of imported goods, and in particular of those goods which are subject to "ad valorem" duties, was mainly responsible for the large customs revenue for the years 1918-19 and

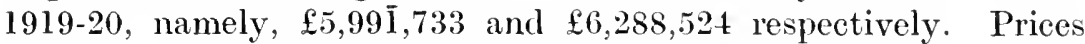
continued to advance, and in addition the improvement in respect of shipping accommodation led to increased importation. Also, the duties on drinks were further increased in 1919 and again in 1921 . In the latter year the duties on bioscope films and tobacco were also increased.

The following table serves to indicate the significance of the customs revenue in the fiscal system of the Union and the comparatively large yield per capita.

Heading.

Customs Revenue ... ... ...

Percentage of Gross Ordinary

Revenue (Union and Provincial)

Percentage of value of total imports

Per Capita (European Population)

Per Capita (Total Population) ...

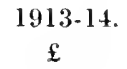

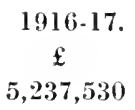

26.4

12.9

e3 14s. Od.

15s. $8 \mathrm{~d}$.
$1919-20$. $\mathfrak{E}$ $6,288,524$

20.8

$$
£ 45 \text { s. Od. }
$$$$
\text { 17s. } 7 \mathrm{~d} \text {. }
$$

The fiscal significance of the revenue from customs duties, in spite of the comparatively low rates (average of 11.3 per cent. in 1913-14), and the large yield per capita of European population are to be attributed to the fact that the Union of South Africa is, to a great extent, dependent upon imported goods. 


\section{CHAPTER 8.}

\section{Excise Duties.}

\section{Introductory.}

The management and control of the collection of excise duties within the Union is vested in the Commissioner of Lxcise, who is also the Commissioner of Customs. The Excise Department is associated with the Customs Department for purposes of administration, the joint Department of Customs and Excise constituting a sub-department of the Department of Finance.

Prior to the establishment of the Union, cach of the four colonies had its own system of administration and collection in respect of excise duties, whieh were confined to spirits and beer. Subsequent to the formation of the Union Department of Excise, the laws of the four provinees governing the collection of excise duties remained in force until consolidating legislation was introduced in 1913.

Under the Union régime excise duties have been levied in respect of spirits, beer, cigarettes, tobacco, sugar, matches. and playing cards.

(a) Spirits.-In 1913 new duties were imposed on spirits distilled in the Union in lieu of those in foree in the several provinces, as follows: ${ }^{1}$

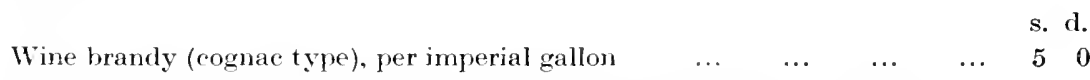

Spirits distilled from the produce of the vine other than wine brandy and

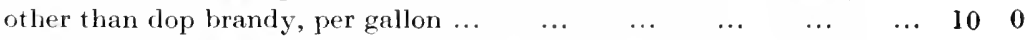

Dop brandy and spirits distilled from materials other than the produce of the

vine, per gallon $\quad \ldots \quad \begin{array}{llllllllllll} & \ldots & \ldots & \ldots & \ldots & \ldots & \ldots & \ldots & 15 & 0\end{array}$

It was provided that in respect of spirits exported for consumption outside the limits of the Union, or used in the fortification or preservation of pure wine, or lost through evaporation or leakage, the whole excise duty was to be rebated. It was also provided that spirits distilled in Natal from the products or by-products of the sugar cane should be subject to a rebate of $5 \mathrm{~s}$. per proof gallon when duty is paid for eonsumption in Natal.

In 1916, in view of the need for additional revenue, the excise duties on spirits were increased by two shillings and sixpence per 
proof gallon." At the same time a corresponding increase was effected in the eustoms duties on imported spirits to countervail the increase in excise duties.

In 1919 the duties on spirits were inereased by an additional two shillings and sixpence per gallon; so that in the period from 1913 to 1919 the excise duties on wine brandy were doubled, while those on grape brandy were subject to a 50 per cent. increase, and those on dop brandy to an advance of $33 \frac{1}{3}$ per cent. The customs duties on spirits were likewise increased, although on this oceasion by more than the advance in excise duties. And in 1921 the duties were once more increased by 2s. 6d. per gallon, thus making the duty on wine brandy 12s. 6d. per gallon, on grape brandy $17 \mathrm{~s} .6 \mathrm{~d}$. and on dop brandy $\mathfrak{f l} 2 \mathrm{~s} .6 \mathrm{~d}$.

(b) Beer.-In 1913 the duties on beer were rendered uniform throughout the country, in the following manner :

s. d.

Beer brewed from worts of the specific gravity of less than 1040 degrees, per

$\begin{array}{llllllllllll}36 & \text { imperial gallons } \\ \ldots & \ldots & \ldots & \ldots & \ldots & \ldots & \ldots & \ldots & \ldots & 6 & 0\end{array}$

Beer brewed from worts of the specific gravity of 1040 degrees and over, per

$\begin{array}{llllllllllll}36 & \text { imperial gallons } & \ldots & \ldots & \ldots & \ldots & \ldots & \ldots & \ldots & \ldots & 12 & 0\end{array}$

In 1915 the excise duties imposed on beer brewed in the Union were increased by 50 per cent, ${ }^{+}$and in 1919 by an additional 50 per cent., making the duties $12 \mathrm{~s}$. and $\mathfrak{f l} 4 \mathrm{~s}$. respectively ${ }^{5}$; so that during the period from 1913 to 1919 such duties were doubled. In 1921 these duties were further increased to 15s. and $£ 110 \mathrm{~s}$. respectively.

With regard to spirits and beer manufactured in the Union, it is provided by law that the manufacturer or dealer is to keep such books and documents as will show clearly the stocks in hand at the time when increased exeise duties are proposed, and is to permit all such books and documents and all such stocks to be open to inspection by the proper officer of excise. ${ }^{6}$

(c) Cigarettes and Tobacco.- In 1909 the Parliament of the Cape of Good Hope imposed a tax on eigarettes retailed. This tax was repealed in 1911 by the Union Cigarette Excise and Surtax Act, which imposed an excise duty on eigarettes imported into the Union, in the following manner : ${ }^{7}$

2 Act 37 of 1916 , Schedule, Part 2.

3 Act 37 of 1913 , First Schedule, Part 1.

4 Act 22 of 1915, Second Schedule.
5 Act 32 of 1919, Schedulc, Part 2.

6 Act 7 of 1913 . sec. 6 .

7 Act 16 of 1911 , Schedule 1. 
On all cigarettes manufactured in the Union, an excise duty for every one. half ounce net weight or fraction thereof $\quad \ldots \quad \ldots \quad \ldots \quad \ldots$ On all cigarettes imported into the Union and delivered for consumption therein, a surtax (in addition to the duty payable under the Customs laws) for every one-half ounce net weight or fraction thereof ... ... In 1922 this duty and surtax on cigarettes was increased to ${ }_{4}^{3} \mathrm{~d}$. per one-half oz.

Under the Cape law the excise duty on cigarettes was collected by means of stamps affixed to the tin, box, package, or other container at the time of their retail sale, whereas under the Union law the duty is collected from the manufacturer by means of stamps affixed to the container before shipment from the factory, or from an importer at the time of their first importation or delivery from a bonded warehouse. Nanufacturers overseas are allowed to purchase the necessary stamps and to affix them to the containers of cigarettes at the time of manufacture. 8

Tobacco.-In 1921, excise duties were imposed on tobacco manufactured in the Union for sale, and the customs duties were correspondingly increased. The following were the rates of these excise duties on tobacco manufactured in the Union:

(a) ready for smoking in a tobacco pipe, including cake, plug and

$\begin{array}{llllllllll}\text { stick tobacco } & \ldots & \ldots & \ldots & \ldots & \ldots & \ldots & \ldots & \text { ls. Od. per lb. }\end{array}$

(b) ready for use in the making of cigarettes $\quad \ldots \quad \ldots \quad \ldots \quad \ldots$ Is. Od. per lb.

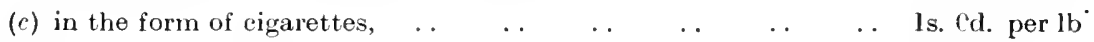

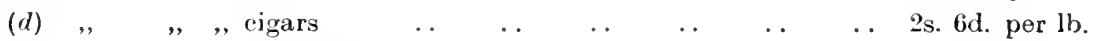

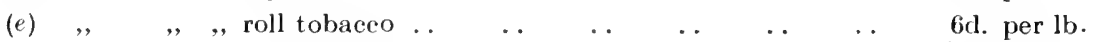

In 1922 these rates were reduced to $4 \mathrm{~d} ., 6 \mathrm{~d} ., 6 \mathrm{~d} ., 1 \mathrm{~s}$. and $3 \frac{1}{2} \mathrm{~d}$. per 。 Ib. respectively. They are in arddition to the abovementioned excise duty on cigarettes of $\frac{3}{4} d$. per half-ounce.

(d) Sugar.-In 1915 an excise duty was imposed on sugar manufactured or refined in the Union, to the extent of $1 \mathrm{~s}$. per $100 \mathrm{lb} .^{9}$ The duty was also payable in respect of sugar held in stock or at the order or otherwise in the possession or control of a sugar refiner.

A licence is required for premises on which sugar is manufactured, no fee or other charge being payable on such licence or renewal thereof. The duty is payable quarterly, and the sugar refiner is to furnish a bond to secure the due payment of duty. Sugar refiners are to keep reasonable or proper books or accounts of the transactions relating to their business in such form as will enable a true extract to be made therefrom of the particulars prescribed by regulation. ${ }^{10}$

8 Ibid, sec. 7 .

${ }^{9}$ Act 22 of 1915 , Third Schedule.

10 Act 22 of 1915 , Secs. 7-13. 
(e) Matches.-In 1914 an exeise duty was imposed on matehes manufactured in the Union, as follows: ${ }^{11}$

(1) In boxes or packages of not more than 100 matches, per gross of boxes or $\begin{array}{lllllllllll}\text { packages } & \ldots & \ldots & \ldots & \ldots & \ldots & \ldots & \ldots & \ldots & \ldots\end{array}$

(2) In boxes or packages containing more than 100 matches, but not more

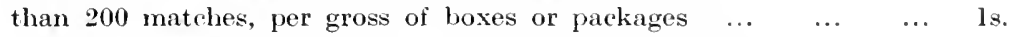

And for every additional 100 matches, in boxes or packages, per gross of 100 matches

(f) Playing Cards.-The Excise Duties Extension Act of 1915 imposed a duty on playing cards manufactured in the Union, at the rate of $3 \mathrm{~d}$. per pack (not exceeding fifty-three cards). ${ }^{12}$

In the case of sugar, matches, and playing cards, as in the case of spirits, beer, and cigarettes, the customs duties were increased to countervail the excise duties.

(g) Acetic and Pyroligneous Acids, etc.-In 1913 the following excise duties were provided for in respect of acetie and pyroligneous acids, extracts and essences of vinegar produced in the Union. ${ }^{13}$

If of a strength not exceeding the strength of proof, per gallon or fraction of $\begin{array}{llllllllllll}\text { a gallon } & \ldots & \ldots & \ldots & \ldots & \ldots & \ldots & \ldots & \ldots & \ldots & l_{s} .\end{array}$

And in addition for each degree of strength in excess of the strength of proof, per degree. (Proof held to be equal to 6 per cent. of absolute acid). ...

$4 d$.

Provision is made for the rebate of the whole duty if such acids or extracts are exported from the Union for consumption elsewhere.

\section{Excise Revenue.}

As a result of the imposition of new excise duties since the establishment of the Union and the increases in the existing duties, the revenue from exeise has undergone a considerable increase, as indicated in the following table $:^{14}$

\section{Heading.}

\begin{tabular}{|c|c|c|c|c|c|c|c|c|}
\hline & & & & $\mathfrak{E}$ & $£$ & $£$ & $f$ & $£$ \\
\hline Spirits & $\ldots$ & $\ldots$ & $\ldots$ & 239,954 & 343,319 & 475,095 & 675,291 & 880,296 \\
\hline Beer & $\ldots$ & $\ldots$ & $\ldots$ & 91,455 & 94,751 & 131,583 & 158,705 & 249,247 \\
\hline Cigarette & & $\ldots$ & $\ldots$ & 163,323 & 175,450 & 198,640 & 256,505 & 323,384 \\
\hline Sugar & $\ldots$ & $\ldots$ & $\ldots$ & - & - & 122,029 & 123,355 & 162,923 \\
\hline Matches & $\ldots$ & $\ldots$ & $\ldots$ & - & 16,647 & 26,122 & 26,041 & 31,137 \\
\hline Playing & Cards & $\ldots$ & $\ldots$ & - & - & 1,490 & 1,676 & 858 \\
\hline Miscellan & neous & $\ldots$ & $\ldots$ & 306 & 596 & 321 & 324 & 314 \\
\hline & Total & 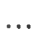 & ... & 495,038 & 630,763 & $5 \tilde{5}, 280$ & 41,897 & $, 648,159$ \\
\hline
\end{tabular}

11 Act 13 of 1914, Schedule.

12 Act 22 of 1915 , Fourth Schedule.

13. Act 37 of 1913, First Schedule,
14 O.Y.B. 1919, p. 835 and Auditor. General's Report for 1919-20, p. 85.

Part 1. 
The large increase in the yield of the excise duties on spirits and beer during the period under consideration is to be attributed partly to the increases in the duties and partly to the increased consumption of Union spirits and beer as a result of the decreased importation of those commodities. The revenue from the cigarette excise was doubled during the period in spite of the fact that the duty remained stationary, the increase in revenue being due to increased consumption, partly on account of the large number of troops which passed through the Union.

With regard to sugar, the increase in the excise revenue derived from this source has been due to greater production and the more extended use thereof in the local manufacture of jams and confectionery. The revenue from the duty on matches was also subject to increase, which was likewise due to greater production.

Taken as a whole, the cxcise revenue of the Union was more than trebled during the period from 1912-13 to 1919-20. Whereas in the beginning of the decade it was an item of comparatively small significance, the end of the decade found it a factor of importance. This exceptional increase in the excise revenue is, as has been pointed out, the result of three factors, namely, $(a)$ increases in the duties on spirits and beer, $(b)$ the imposition of new duties, and (c) the increased consumption of the local article in view of the difficulties experienced in the importation thereof from abroad in some cases and the prohibitive prices of the imported articles in other cases.

The excise revenue does not by any means play an insignificant role in the fiscal system of the Union. During the last four years of the decade the excise receipts represented on an average about 5 per cent. of the gross ordinary revenue of the Union. The yield per capita of European population is comparatively large, but in terms of total population it appears to be small.

\begin{tabular}{|c|c|c|c|c|c|}
\hline Heading. & $\begin{array}{l}1912-13 . \\
\mathfrak{f}\end{array}$ & $\begin{array}{l}1914.15 . \\
£\end{array}$ & $\begin{array}{l}1916 \cdot 17 . \\
\qquad\end{array}$ & $\begin{array}{l}1918-19 . \\
\mathfrak{f}\end{array}$ & $\begin{array}{l}1919 \cdot 20 . \\
\mathfrak{E}\end{array}$ \\
\hline Excise Revenue ... & 495,038 & 630,763 & 955,280 & $1,241,897$ & $1,648,159$ \\
\hline Percentage of & & & & & \\
\hline $\begin{array}{l}\text { Ordinary Revenue } \\
\text { (Union and Provincial) }\end{array}$ & 2.8 & 4 & 4.8 & 5.1 & 5.4 \\
\hline Per Capita of European & & & & & \\
\hline Population $\quad \ldots$ & $7 \mathrm{~s} .7 \mathrm{~d}$ & $9 \mathrm{s.} \quad 4 \mathrm{~d}$. & $13 \mathrm{~s} . \quad 5 \mathrm{~d}$. & $17 \mathrm{~s} . \quad 0 \mathrm{~d}$ & £l 2s. 0d. \\
\hline Per Capita of Total Popu. & & & & & \\
\hline lation $\ldots$ & 1s. $7 \mathrm{~d}$. & 1s. $11 \mathrm{~d}$. & $2 \mathrm{~s} .10 \mathrm{~d}$. & 3s. 6d. & $4 \mathrm{~s}$. \\
\hline
\end{tabular}




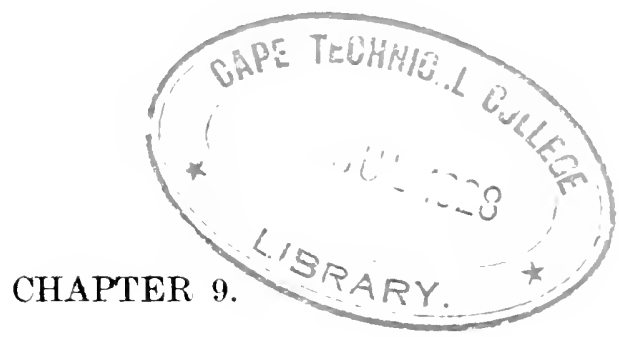

Ixcone and Excess Profits Taxis.

Prior to the Union the taxation of income was in vogue only in the Cape of Good Hope, where it was instituted in 1904. Upon the establishment of the Union, however, the Cape income tax was abolished; but by 1914 the need for additional revenue had rendered it necessary for the Union Government to introduce an income tax into its fiscal system. The initial Union income tax was of very limited application, but as the result of fiscal necessity created by the abnormal war conditions its scope was annually extended until in 1917 an elaborate consolidating ineome tax was brought into being.

The Income Tax Act of 1914 provided for an abatement of $£ 1,000$ and various exemptions. "Taxable income" was interpreted as income in excess of $£ 1,000$ which was received by any person wheresoever residing from any source in the Union during the twelve months ended June $30,1914 .^{1}$ The rates in respect of the taxable amount of any taxable income were as follows :

(a) Where the taxable amount was $\mathfrak{k l}$, the rate of income tax was $6 \mathrm{~d}$.;

(b) As the taxable amount increased, the rate of income tax per $£ 1$ of the taxable amount increased uniformly at the rate of $1 / 2000$ th. part of a penny for each $£ 1$ of the taxable amount up to $£ 24,000$, so that in respect of a taxable amount of $£ 24,000$ the rate was 1s. 6d. for every $£ 1$ thereof; and this rate applied to all taxable amounts in excess of $£ 24,000 .^{2}$

In 1915 three important amendments were introduced. In the first place, the abatement was reduced to $£ 300$, and no abatement was allowed in the case of taxable incomes in excess of $£ 24,300$. Secondly, secondary abatements were provided for in the case of

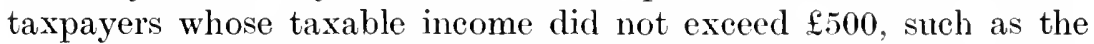
sum of $£ 20$ for each child under the age of 16 years on the first day of the year in respect of which a return was made of the taxable income, and any sum not exceeding $£ 25$ as life or accident or sickness 
insurance premium. ${ }^{3}$ Thirdly, the rates were increased as follows : (a) on every taxable amount not exceeding $£ 24,000$ the rate for every $£ 1$ of the taxable amount was 1 s. and as many two-thousandths of a penny as there were pounds; and $(b)$ on every taxable amount exceeding $£ 24,000$ the rate was 2 s. for every $£ 1$ of that amount. ${ }^{4}$

The Income Tax Acts of 1914 and 1915 were re-enacted by the provisions of the Income Tax Act of 1916, which did not differ in any material respects from the previous acts, with two exceptions: $(a)$ the extension of the secondary abatements (children, insurance, and fees to friendly or benefit societies) to taxpayers whose taxable income exceeds $£ 500$, diminished by the amount by which the taxable income exceeds $£ 500 ; 5$ and $(b)$ the introduction of a supertax on incomes exceeding $£ 2,500$, applicable to individuals only and being in addition to the normal income tax. "Supertaxable income" was construed to mean an income in excess of $£ 2,500$ per annum averaged over the period of two years ended June $30,1916{ }^{6}$

In 1917, the Income Tax (Consolidation) Act was passed which repealed the previous acts pertaining to the taxation of income as well as the mining taxation acts. Henceforth, the mines were to be liable to the income tax. In terms of this legislation four taxes were imposed: (1) normal tax, (2) super tax, (3) dividend tax, and (4) excess profits tax. Subject to the annual authority of Parliament for the levy of an income tax, the provisions of the act are permanent except in so far as they may be amended from time to time, and the rates to be levied are to be fixed annually by Parliament. ${ }^{\text {. }}$ Important amendments were introduced in 1921. Since that year the income tax has been constituted as follows.

A. Normal Tax._-"Gross Income" is interpreted as the total amount received by or accrued to any person other than receipts or accruals of a capital nature, and taxable income is an income in excess of $£ 300$ after deducting losses and expenses actually incurred in the Union by the taxpayer in the production of his taxable income, provided they are not of a capital nature, sums expended for the repairs of premises occupied for the purpose of trade, or of machinery, implements and articles employed for the purpose of trade, and sums set aside for depreciation or allowed in respect of depreciation. ${ }^{8}$

3 Act 23 of 1915 , sec 1 ( 2 and 3 ).

4 Ibid, sec. 1 (4).

5 Act 35 of 1916 , sec. 1 (3).

\author{
6 Ibid, sec. $4(2)$; \\ 7 Act 41 of 1917, sec. 5 (2). \\ 8 Act 41 of 1917 , sec. 17 .
}


Income is deemed to have acerued to a person notwithstanding that such income has been invested, aecumulated or otherwise capitalised by him, or that such income has not been actually paid over to him, but has been credited in account or re-invested or otherwise dealt with in his name or on his behalf. ${ }^{9}$

Every person carrying on pastoral, agricultural or other farming operations is required to include in the return rendered by him for income tax purposes the value of all livestoek and produce held by him and not disposed of, provided that the Commissioner for Inland Revenue shall allow such reduction to be made from the value of livestock held by any taxpayer at the end of any year of assessment as may seem to him to be fair and reasonable, having regard to the risks of mortality attaching to such livestoek.

The value to be placed upon such livestoek (other than livestock acquired by purchase for stud purposes) is to be :

(a) in the case of livestock acquired by the taxpayer by purchase, either the purchase price paid or such standard value as is applicable to such livestock;

(b) in the case of livestock acquirer by the taxpayer otherwise than by purchase, the standard value applicable to such livestoek.

The standard value of any class of livestock is to be either

(a) such standard value as may be fixed by the Governor-General by regulation; $\mathrm{or}$

(b) such standard value as may be adopted by the taxpayer in the first return.

The exercise of the option is binding upon the taxpayer in respect of all subsequent returns for income tax purposes. ${ }^{10}$

The taxable amount of any ineome is the amount remaining after deducting the abatements that may be applicable, such as the following :

(1) $£ 300$;

(2) $£ 50$ for each child or stepchild under the age of 18 years;

(3) $£ 30$ for each dependent;

(4) any sum not exceeding $f 50$ as life or accident or sickness insurance premium;

(5) any fees or subscriptions not exceeding $£ 10$ to any friendly or benefit society.

The total of these allowances is subject to reduction as follows: 
(a) in the case of married persons the reduction is to be $£ 1$ for every $£ 10$ by which the taxable income exeeeds $£ 600$;

(b) in the case of unmarried persons the reduction is to be $£ 1$ for every $£$ by which the taxable ineome exceeds $£ 300 .{ }^{11}$

The following diagram will serve as an illustration of the process to be adopted in calculating the taxable amount of any income :

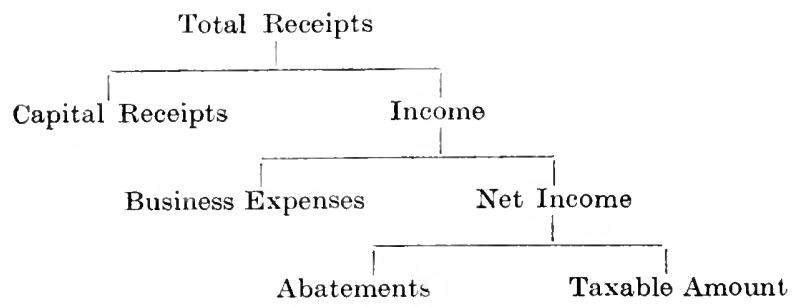

The rates of the normal tax are as follows:

(1) in the case of companies, 1s. 6d. for each $£ 1$ of the taxable amount; provided that in the case of companies wherein

(a) not more than 10 of the largest shareholders hold 90 per cent of the shares;

(b) restrictions are imposed upon the right to transfer shares;

(c) no invitation has been issued to the public to subscribe for any shares or debentures, the rate chargeable shall be that applieable to individuals.

(2) in the case of individuals-

(a) when the taxable amount does not exeeed $£ 24,000$, for each $£ 1$ of the taxable amount $1 \mathrm{~s}$. and as many two-thousandths $\left(\frac{1}{200 \pi}\right)$ of a penny as there are pounds in that amount;-

(b) when the taxable amount exceeds $£ 24,000,2 s$. for each $£ 1$ of that taxable amount. ${ }^{12}$

In the ease of individuals provision has been made for the exemption of dividends reeeived from any eompany in respect of which the dividend tax has been paid, or of interest on debentures or debenture stoek received from any eompany in respeet of which normal tax has been paid by such eompany.

B. Super Tax.-The super tax is a tax on individuals as distinct from eompanies. Supertaxable ineome is taken to be an income exceeding in the aggregate $\{2,500$ per annum, the amount being determined in the following manner. The aggregate eomprises:

(1) the taxable income of the individual as determined for normal tax purposes: 
(2) any dividends or debenture interest which although derived from sources within the Union were excluded in the computation of such ineome.

From such aggregate are to be deducted any losses and expenses, not being of a eapital nature, incurred by such individual within the Union in the production of any dividends or debenture interest described above. ${ }^{13}$

Thus, the basis of the supertax is normal taxable income plus income from debenture interest and dividends, the incomes from these sourees being exempt from normal tax in the assessment of individuals as the tax has been levied thereon in the hands of the companies from which they aecrued, with the proviso that, where the income subject to super tax docs not amount to $£ 5,000$, there shall be deducted an abatement of $£ 2,500$ diminishing by $£ 1$ for every $£ 1$ by which the ineome subject to super-tax exceeds $£ 2,500$. When such income exceeds $£ 5,000$, no abatement is allowed..$^{1+}$

Whenever the dividends distributed by any company wherein not more than ten of the largest shareholders hold 90 per cent. of the shares, are not in the opinion of the Commissioner a fair and reasonable distribution of the profits available for that purpose at the time when such distribution is made, or whenever in such a case no distribution has been made from the profits so available, the Commissioner may, for the purpose of determining the ineome subject to super tax of any shareholder in the said company, add to the dividend aetually loeated or distributed to such shareholder, or where no dividend has been distributed allocate to such shareholder such sum. proportionate to the amount of his shareholding in the company, as may seem to the Commissioner to be fair and reasonable. ${ }^{15}$

The rates of the super tax are as follows:

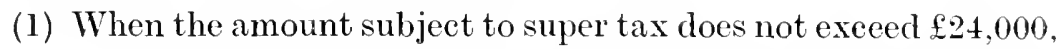
for each $£ 1$ of such amount ls. and as many five-hundredths $\left(\frac{1}{50}\right)$ of a penny as there are pounds in that amount;

(2) When the amount exceeds $£ 24,000,5 \mathrm{~s}$. for each $£ 1$ of such amount. ${ }^{16}$

C. Dividend Tax.-All dividends distributed by companies are liable to the dividend tax subject to specified exemptions and to the following abatement:

Where the aggregate dividends, distributed in any accounting period liable to taxation, do not exceed $£ 5,000$. there is to be deducted

$1 z_{1}$ Act 41 of 1917 , secs. 26 and 27 .

$1+$ ibici, ser. $29 \&$ Act 29 of 1921 , sec. 7 .
15 Act 29 of 1921 , sec. 6 .

16 Ibid, sec. 1 (2). 
from the amount of such dividends an abatement at the rate of

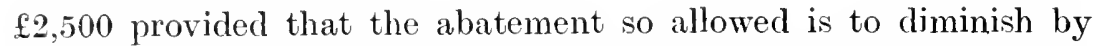
$\mathfrak{f l}$ for every $\mathfrak{f l}$ by which the aggregate dividends so distributed

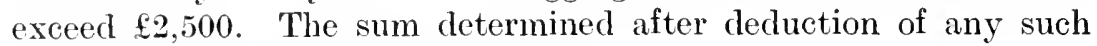
abatement is the taxable amount. ${ }^{17}$

The rates of the dividend tax are as follows:

(1) In respect of companies whose principal business is gold mining, a rate of $1 \mathrm{~s}$. 6d. for every pound of the taxable amount of such dividend;

(2) in respect of companies whose principal business is diamond mining, a rate of $1 \mathrm{~s} .6 \mathrm{~d}$. for every $£ 1$ of the taxable amount of such dividend;

(3) in respect of all other companies a rate of $1 \mathrm{~s}$. for every $£ 1$ of the taxable amount. ${ }^{18}$

Special provision is made that no company and no person acting on behalf of a company shall distribute any dividend chargeable with the tax until the tax payable in respect of such distribution has been paid, ${ }^{19}$

D. Excess Profits Tax.-The excess profits tax was instituted in 1917 as a temporary measure, for the period of the war and six months thereafter, ${ }^{20}$ the date of the termination of the war to be declared by the Governor-General in the Government Gazette, and was intended for the benefit of the loan account towards meeting war expenditure chargeable thereon. During the financial years 191718 and 1918-19 mole than $£ 1,000,000$ was collected in respect of the excess profits tax and paid into the loan account, but under the Income Tax Act of 1919 all amounts of excess profits duty collected after April 1, 1919, were to be assigned to the revenue account. ${ }^{21}$ This attitude on the part of the Union Government is to be deplored, since the yield of the excess profits tax constituted an extraordinary revenue to be applied only to extraordinary expenditures, and since there was no clear case of fiscal emergency, the year 1919-20

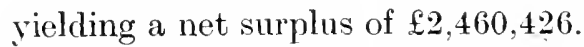

The excess profits tax was levied on all companies and individuals, carrying on any trade or business, whose profits for the accounting periods subject to that form of taxation exceeded by more than $£ 500$ their profits for the year ended June 30, 1914. The determination of excess profits was based upon the pre-war standard of profits, which was defined as the taxable income of any company

17 Ibid, sec. 36 .

18 Act 41 of 1917 , sec. 35 .

19 Ibid, sec. 47 .
20 In view of fiscal necessity the excess profits tax was extended to 1921. 21 Act 39 of 1919 , sec. 5 (2). 
or individual derived from any trade or business or inclustry for the year ended June 30, 1914, when computed on the same principles as are applicable for the computation of a taxable income for normal tax purposes, or upon a statutory percentage of the capital in cases in which such is allowable: $(a)$ in the case of companies a minimum of $s$ per cent. per annum, and $(b)$ in the case of individuals a minimum of 10 per cent. per annum. (Capital was interpreted as the net vahue of the assets employed. ${ }^{22}$ ). Thus the excess profits tax, as levied in South Africa, was virtually a war profits tax, although it contained the elements of an excess profits tax proper (i.e. profits in excess of a certain percentage) in the case of concerns established sinee the outbreak of the war. It was based mainly on the British excess profits tax.

The rate of the excess profits tax was fixed by the Income Tax Act of 1917 at $5 \mathrm{~s}$. in the $\mathfrak{f}^{23}$, but was increased to $10 \mathrm{~s}$. in the $\mathfrak{f}^{24}$ by the Income Tax Act of 1919 .

Innorations.-The innovations introduced by the Income Tax (Consolidation) Act of 1917 may be summarised as follows :

(1) special provisions relating to the taxation of profits from mining which were formerly taxed under Mining Taxation Acts ;

(2) the substitution of a normal tax at a flat rate, plus a dividend tax, for the taxation of companies' profits in place of a normal tax with a progressive rate of tax as formerly applied to such profits;

(3) the taxation of dividends and debenture interest at the source of payment, and, except in the case of the super tax, not in the hands of the individual recipients ;

(4) the imposition of a temporary excess profits tax.

Sources of Income.- The following table ${ }^{25}$ presents the various sources of income in the order of the amount of the taxed ineomes accruing therefrom and the distribution of such incomes between individuals and eompanies in respect of the normal tax for the year ended 30 June, 1917.

22 Act 41 of 1917 , sec. 50 .

23 Ibid, sec. 49 .
24 Act 39 of 1919 , sec. 5. (1).

25 O.Y.B. 1919 , p. 840 . 
Source of Income

Amount of Taxed Incomes.

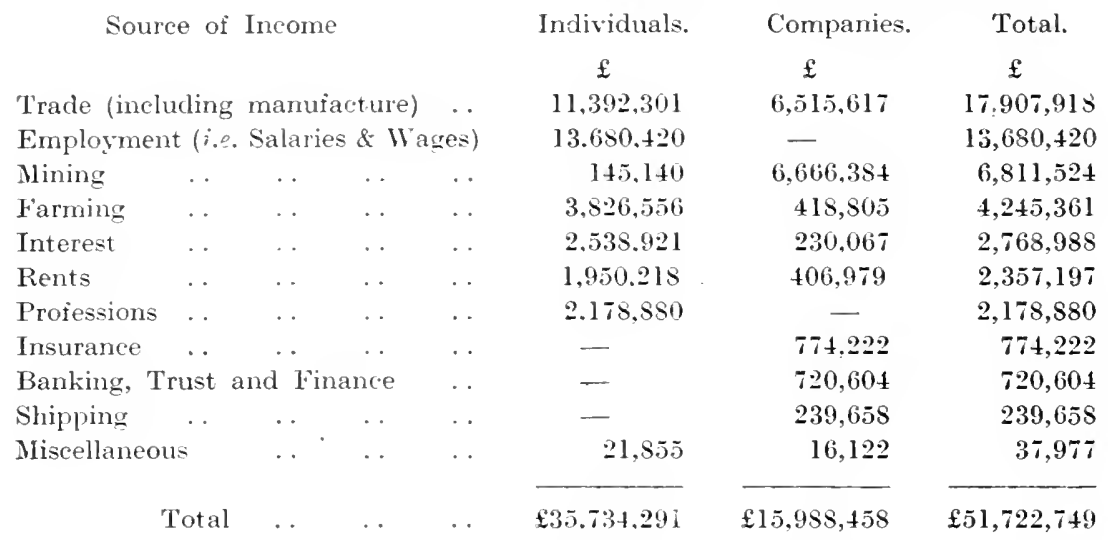

Trade and manufacture accounted for more than one-third of the total amount of incomes subject to the normal tax. With regard to "employment," the salaries and wages in the public service liable to the normal tax amounted to $£ 3,065,710$, or almost 25 per cent. of the total amount of salaries and wages taxed.

The number of taxparers subject to the normal tax for the year under consideration was 49,437 , and the amount of the tax paid was $£ 1,995,590$, representing $3 \frac{1}{2}$ per cent. of the total amount of taxed incomes.

In respect of the super tax the number of taxpayers was 1,523 , the amount of supertaxable income $£ 8.438,581$ and the amount of the super tax paid was $£ 482,056$, or 5.7 per cent. of the total amount of supertaxable incomes. ${ }^{26}$

The taxed dividends were distributed amongst the three groups of companies in the following manner :

Taxed 1)ividends.

Gold-mining Companiez . . .

Diamond-mining Companies ..

All other Companies

Total
$£$

$6.750,370$

2.417 .653

$4.601,878$

$£ 13,799,901$

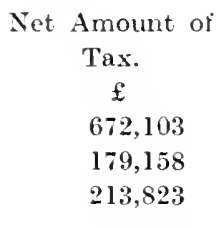

$£ 1,065,084$

The total amount of excess profits was $£ 2,259,700$, of which $£ 930,276$ was assigned to individuals and $£ 1,329,424$ to companies, and the number of taxpayers liable to the excess profits tax was 979 , namely 737 individuals and 242 companies. ${ }^{26}$ 
Amount of Abatements.- The abatements allowed as deductions for normal tax purposes in respect of taxable incomes for the rear ended June 30, 1917, amounted to £14,598.2.50 :

Primary Abatement $(\mathfrak{£} 300)$

Individuals. Companies.

Total.

Secondary Abatements (such as allowances for children, dependents, insurance, and fees to friendly societies). .

\begin{tabular}{ccc}
$\mathfrak{f}$ & $\mathfrak{f}$ & $\mathfrak{f}$ \\
$12,923,392$ & 318,140 & 13.241 .532 \\
& & \\
$1,356.718$ & - & $1,356.718$ \\
\hdashline $14.280,110$ & $£ 318,140$ & $\frac{14,595.250}{140}$
\end{tabular}

In addition to the aforementioned abatements, the abatements allowed as deductions from supertaxable incomes amounted to $£ 2,400,547$, thus making a total of $£ 16,998,797$ for the year.:-"

General Characteristics of Income Tax.-The South African ineome tax constitutes an admirable example of a combination of the two main types of income tax, namely the so-called "stoppageat-the-source" income tax and the "lump sum "income tax, the former being most completely organised in England and the latter in Germany. It represents an attempt to secure the characteristic advantages of both types in a compromising measure. The "lump sum " income tax requires considerable arministrative efficiency, but it possesses the great advantage of permitting the application of the principle of progression. On the other hand, while the "stoppageat-source" income tax presents serious impediments to the introduction of progression, it facilitates collection, minimises evasion and fraud, and avoids the adoption of undue inquisitorial procedure.

The principle of taxation at the source is applied merely to dividends through the dividend tax, and indirectly also to debenture interest through the normal tax on the ineome of companies, i.e.. to those elements of income which are most easily and conveniently stopped at the source. The exemption, in the case of the normal tax on individuals, of interest on debentures or debenture stock received from any company in respect of which normal tax has been paid by such company amounts practically to discrimination in favour of debenture stock as against capital stock.

The dividend tax is designed to secure not only stoppage at the source but also differentiation in the taxation of eompanies, the gold-mining and diamond-mining companies being subjeet to a higher rate than other companies. The gold-mining companies had

27 Report of Commissioner for Inland Revenme, 1917-15, p. 13. 
been rendered liable in 1917 to an additional $6 \mathrm{~d}$. in the $£$ as a special war levy.

The principle of progressive rates is applied to individuals both in respect of the normal and the super tax, companies being exempt from the super tax and subject to a flat rate under the normal tax. There is a fixed limit to progression in either case, progression ceasing at $£ 24,000$ in the normal tax on individuals and also in the super tax. Degressive progression is attained by means of an elaborate system of abatements, even in the case of the normal tax on companies up to $\mathfrak{2} 2,300$ and in the dividend tax up to $£ 5,000$, beyond which limits the abatements are not allowed.

Revenue from Income Tax.-The yield of the income tax has been subject to constant increase according as the scope thereof was extended and the rates were raised. In 1914-15 the income tax revenue constituted an insignificant item, whereas by 1919-20 it was seeond only to the customs revenue and had come to occupy an important place in the fiscal system of the Union.

Heading. 1914-15. 1915-16. 1916-17. 1917-18. 1918-19. 1919-20. $£ \quad £ \quad £ \quad £ \quad £$

Revenue from Income

Tax (including

Super Tax and Divi. dend Tax) .. $446,597 \quad 1,028,953 \quad 1,465,40 ! \quad 3,860.282 \quad 4,298,000 \quad 4,696.435$ Percentage of Ordinary

Gross Revenue

(Union and Provin.

$\begin{array}{llllllllll}\text { ciał) } \ldots & \ldots & \ldots & 2.9 & 5.8 & 7.4 & 18 & 17.9 & 15.5\end{array}$

Per capita of European

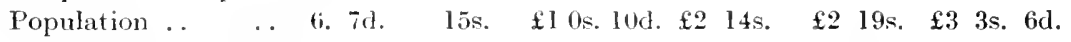
Per capita of Total

Population .. .. 1s. 5d. 3s. 2d. 4s. 5d. 11s. 3d. 12s. 4d. 13s. 2d.

The income tax receipts for 1915 -16 are more than double those for 1914-1915 on account of the reduction in the primary abatement from $£ 1,000$ to $£ 300$ and the increase in the rates authorised by the Income Tax Aet of 1915. The receipts for 1916-17 show a further increase as the result of the introduction of a super tax on

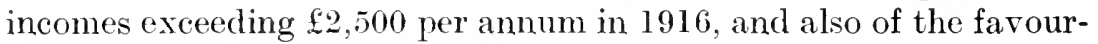
able trading conditions and restriction of competition due to prevailing war conditions. In 1917-18 there was an extraordinary increase in the revenue from the income tax which may be attributed to several factors.

In the first place, under the Income Tax (Consolidation) Act of 1917 the profits of mining which had prior to that year been taxed in 
accordance with the provisions of speeial mining taxation acts were rendered liable to income tax, with the result that a sum of about $£ 1,500,000$ was transferred from the head of "mining revenue " to that of "income tax revenue." Secondly, the legislation referred to provided for a special dividend $\operatorname{tax}$ on the dividends of companies. And thirdly, the restriction of imports from overseas had stimulated local production, industrial as well as agricultural, thereby enhaneing the national income.

In 1918-19 and 1919-20 the income tax receipts were subject to further increases as the results of $(a)$ larger dividend distributions in view of the enhanced price of diamonds and the premiums on gold, $(b)$ increased profits on trading, $(c)$ inerease of wages, and $(d)$ general trade expansion.

Summing up, then, the extraordinary increase of 1,000 per cent. in the income tax revenue of the Union during the five-year period from 1914-15 to 1919-20 may be ascribed to the following factors :

(1) the reduction of the primary abatement from $£ 1,000$ to $£ 300$;

(2) the increase in the initial rate from $6 \mathrm{~d}$. in the $f$ to $1 \mathrm{~s}$., and in respect of a taxable amount of $£ 24,000$ or over from ls. $6 \mathrm{~d}$. in the $£$ to $2 \mathrm{~s}$.;

(3) the addition of a super tax and a dividend tax ;

(4) the inclusion of the profits of mining;

(5) increase in incomes in consequence of the enhanced prices and increased production occasioned by war conditions.

With regard to fiscal significance, the income tax revenue constituted 18 per cent. of the gross ordinary revenues (Union and Provincial) in 1917-18, deelining to $15 \frac{1}{2}$ per cent. in 1919-20 in view of the greater enhancement of other items of revenue, such as customs and excise receipts, mining revenue, etc.

\section{Revenue from Excess Profits Tax.}

\section{Fiscal Year.}

1917.18

1918-19

1919.20
Contributions to the

Loan Account. ${ }^{25}$

$$
\begin{gathered}
£ \\
269,824 \\
945,417
\end{gathered}
$$

Contributions to the Revenue Account. ${ }^{2}$

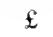

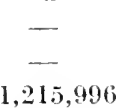

The excess profits tax was introduced into the Union tax system by the Income Tax (Consolidation) Act of 1917, in accordance with

28 Half-yearly Abstract of Union Statisties, June 1919, p. 81 .
29 Auditor-General's Report for 1919 . 1920 , p. ss. 
which it was to be levied for the benefit of the loan account towards meeting war expenditure chargeable thereon, but under the Income Tax Act of 1919 the receipts from the excess profits tax were to be paid into the revenue account, and at the same time the rate was increased from $5 \mathrm{~s}$. in the $£$ to $10 \mathrm{~s}$. in the $£$, thereby securing an increase in the receipts for 1919-20 as compared with those for 1918-19. However, this increase proved to be below the estimated increase due to the fact that the temporary fall in the value of trading stocks after the armistice resultcd in reduced comparative profits. ${ }^{3.1}$

Provincial Excess Profits Tax.-In 1917 an ordinance was passed by the Provincial Council of the Transvaal providing for the imposition of a tax on excess profits within that province in respect of the year ended 30th June, 1917. This excess profits tax was to be equivalent to one-fifth of the excess profits duty as assessed under the provisions of the Union Income Tax (Consolidation) Act of 1917. Exemption was allowed in favour of profits derived from sources outside the province. ${ }^{31}$

The revenue yiclded by this tax during the financial year 1917-18 amounted to $£ 13,647,^{32}$ or .9 per cent. of the total revenue of that province (including the Union subsidy).

The tax on excess profits was not re-imposed in the Transvaal in the following years as it was much resented, on the ground that a similar tax was at the same time being levied by the Union Government.

3 Transval Ordinance 22 of 1917 , Statistics, June 1919, p. 81 . sec. 3. 


\section{Mining Taxation.}

Prior to the establishment of the Union the gold mines in the Transvaal were subject to a tax of 10 per eent. on the net profits earned, which was imposed by the Crown Colony Administration in 1902 as being the equivalent of the charges indireetly levied by the Republican Government upon the gold industry before the AngloBoer War. In the ease of diamond mines the Transvaal Government was entitled to a partnership share of 60 per cent. of the net profits and the Orange Free State Government to 40 .per eent. In the Cape Colony there was no speeial tax on gold or diamond mines, but the De Beers (Diamond Mining) Company was subject to the income tax, which was graduated in such a manner as to fall most heavily on the largest ineomes.

Upon the establishment of the Union in 1910 legislation was introdueed to consolidate the various mining tax laws of the four provinees, known as the Mining Taxation Act of 1910, which imposed a uniform profits tax of 10 per eent. in respect of precious metals and precious stones and a graduated tax in respect of other minerals, ranging from $2 \frac{1}{2}$ per cent. upwards. The income tax in the Cape of Good Hope was abolished coneurrently with the imposition of a profits tax on mines throughout the Union.

The subject of mining taxation is to be treated under three distinct headings, namely, ordinary taxation of the profits of mining (i.e. under the Mining Taxation Act of 1910), the speeial war levy on the profits of gold mines imposed in 1915 and 1916, and the export duty on diamonds imposed in 1916.

(1) Ordinary Taxation of the Profits of Mining.- The Mining Taxation Act of 1910 provided for the imposition of the following taxes: ${ }^{1}$

(a) on the profits of mining for diamonds, 10 per eent.;

(b) on the profits of mining for gold, 10 per eent.;

(c) on the profits of mining for other minerals, according to the following seale : 
If the amount of profit does not exceed 5 per cent. of the gross revenue derived

If the amount of profit cxceeds 5 per cent. but does not exceed 10 per cent.

$\begin{array}{lllllllll}\text { of the gross revenue } & \ldots & \ldots & \ldots & \ldots & \ldots & \ldots & \ldots\end{array}$

10-15 per cent. of gross revenue

$15-20$

$20-30$

$30-40$

and thereafter for every additional 1 per cent. of profit an addition of $1 / 10$ th per cent. to the rate of the tax.

"Profits" was interpreted as including all revenue derived from the mining, winning or disposal of the diamonds, the gold, or the other minerals (as the case may be), or from any product in connecttion therewith, after deducting therefrom the amount of the working expenditure and an allowance for amortization of capital expenditure. ${ }^{2}$

With regard to the allowance for amortization of capital expenditure, the amount to be deducted was to be such sum as, if paid by way of annuity from the commencement of production for the whole period during which it was estimated that the mine would continue to be workable, would produce at the rate of 3 per cent. per annum (compound interest) a sum equal to the amount of the capital expenditure, the workable period to be determined by the Government Mining Engineer. ${ }^{3}$

Provision was made for exemption from this tax on the profits of mining in cases where such profits did not exceed $£ 1,000$ during the tax year. ${ }^{4}$

Revente from Ordinary Mining Taxation.

\begin{tabular}{|c|c|c|c|c|c|c|}
\hline Source of Re & & $\begin{array}{c}1911-12 . \\
£\end{array}$ & $\begin{array}{c}1913-14 . \\
£\end{array}$ & $\begin{array}{c}1915-16 . \\
£\end{array}$ & $\begin{array}{c}1916-17 \\
f\end{array}$ & $\begin{array}{c}1917.18 . \\
f\end{array}$ \\
\hline Gold Mines & . & $1,003.546$ & $1,049.067$ & 952,009 & 951,776 & - \\
\hline Diamond Mines & .. & 475,445 & 534,308 & 15,848 & 150,119 & 27,999 \\
\hline Other Mines & . & 32,637 & 33,956 & 13,616 & $-3,543$ & 19,480 \\
\hline
\end{tabular}

The receipts from gold mines showed a small decrease in 1915-16 and 1916-17 as compared with 1913-14, due to the increased working costs and the consequent reduction in profits. The revenue from diamond mines was subject to a considerable decline in 1915-16 as a result of the disturbance in the diamond industry on the outbreak of the European War. The diamond mines were practically closed from September, 1914 until January, 1916, when the wave of

2 Act 6 of 1910 , sec. 4. $\quad$ I Ibid, sec. 7 .

3 Ibid, sec. 5. 
prosperity in the United States eansed the renewal of mining operations, and a rapid recovery of the industry followed. The increase in 1916-17 was due to the revival of diamond mining. With regard to the other mines, the negative amount of $£ 3,543$ was the outeome of a readjustment between the mining profits tax and the income tax in terms of the Mining Taxation Amendment Act of 1915, which provided that in the ease of base metal companies the profits of mining might be liable to the income tax instead of the mining tax. The amount transferable to the income tax in respect of payments made during 1914-15 and 1915-16 cxeecded

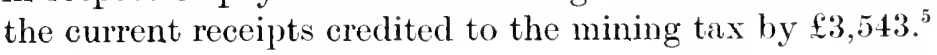

The Income $\operatorname{Tax}$ (Consolidation) Act of 1917 stipulated that the profits of mining were heneeforth liable to the income tax, and special provisions were included in the Act for the taxation of the profits of mining, such as the normal tax on eompanies at a flat rate plus a dividend tax, the latter bearing most heavily on the goldmining and diamond-mining companies. It was provided that the profits of mining companies whose accounting period elosed on a date subsequent to June 30,1917 , were to be assessable for tax under the Income Tax Aet, but in eases where the aceounting period closed prior to that date the profits were assessable under the Mining Taxation Act. This provision accounted for the small revenue of 1917-18 amounting merely to $£ 47,479$, as the great bulk of the revenue from taxes on mines had been transferred to the accounting head "income tax."

The fiscal significance of the revenue from ordinary mining taxation during the financial years 1911-12 and 1913-14 is indicated in the following table.

Heading.

Revenue from Ordinary Mining Taxation

Percentage of Gross Ordinary Revenue (Union and Provincial)

Per Capita of European Population ...

Per Capita of Total Population
$1911-12$.

$£$

$1,511,62 \mathrm{~s}$

10.6

£1 3s. 7 d.

5s. Od.
1913-14.

$£$

$1,617,331$

9.3

$£ 1$ 4s. 4 d.

5s. $2 \mathrm{~d}$.

(2) Special War Levy on Gold Mines.-Under the Mining Taxation Amendment Aet $^{6}$ of 1915 provision was made for a special

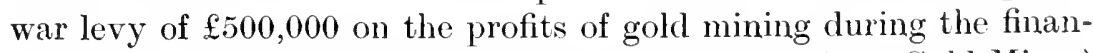
cial year 1915-16; and in 1916 the Special War Tax (Gold Mines) Act $^{\top}$ was passed, authorising the imposition during the financial

5 Auditor-General's Report for 1916 . 1917 , p. 27.

\section{Act 24 of 1915 .}

7 Act 34 of 1916 . 


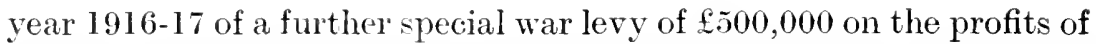
gold mining, in addition to the ordinary mining tax. In both cases the special levy was to be apportioned amongst the mines in such a way that the amount paid by each mine bore the same proportion to its profits as $£ 500,000$ bore to the whole amount of the profits assessed during that year. ${ }^{8}$

Thus, the profits of gold mining were rendered subject to a special war eontribution of $£ 1,000.000$, which was payable in four instalments, the first of which fell due for payment in the financial year ended March 31, 1916, and the last instalment in the financial year ending on March 31, 1918. This special war contribution was paid as follows: ${ }^{9}$

\begin{tabular}{|c|c|c|c|c|c|c|c|c|}
\hline Financial years: & & & & & & & $\mathfrak{E}$ & $\mathfrak{f}$ \\
\hline $1915-16$ & . & . & . & . & .. & . & 301,186 & \\
\hline $1916-17$ & $\cdots$ & . & $\cdots$ & . & .. & . & 198,814 & \\
\hline $1916 \cdot 17$ & . & . & . & .. & . & . & 277,725 & 500,000 \\
\hline 1917.18 & . & $\cdots$ & $\cdots$ & $\cdots$ & . & . & 222,275 & \\
\hline
\end{tabular}

This special contribution represented approximately $5 \frac{1}{2}$ per cent. of the assessed profits of mining during the years 1915-16 and 1916-17.

Under the Income Tax (Consolidation) Act of 1917 the rate of the dividend tax on the dividends of gold-mining companies was fixed at $2 \mathrm{~s}$. in the $\mathfrak{E}$, of which $6 \mathrm{~d}$. was deemed to be a special war levy. ${ }^{10}$

(3) Export Duty on Diamonds.-In 1916 provision was made for the imposition of a duty on the value of rough and uncut diamonds which, having been found in the Union, are exported therefrom. This duty was introduced on account of the need for more revenue in view of the increase in the interest charge by $\$ 1,000,000$ in respect of war debt incurred during the first two years of the war, and in view of the reduction in the yield from certain sources of revenue consequent upon the outbreak of the war.

Under the Diamond Export Duty Act of 1916 the rate of duty was a percentage of the value of the diamonds exported, ranging from one-half of one per cent. to five per eent., and was based upon the percentage ratio of profits to revenue. When the amount of profits exceeded $35 \mathrm{per}$ cent. of the revenue derived, the rate of duty

\footnotetext{
8 Act 34 of 1916 , sec. $2(d)$.

9 Report of Commissioner for Inland

10 Act 41 of 1917 , sec. 35 . Revenue 1916.17 , p. 9.
} 
was one-half of one per cent or a proportionate part thereof for every three-quarters of one per cent. or portion of three-quarters of one per cent. of the excess over and above 35 per cent., rising until the maximum rate of duty reached 5 per cent. When the amount of profits did not exeeed 35 per eent. of the rerenue, no duty was payable. ${ }^{11}$

The duty was not payable in respect of alluvial diamonds found by any digger or by any individual as distinguished from a corporate body. The duty was to be paid by the producer on exportation of diamonds or delivery within the Union; and a drawback was allowed in respect of the duty paid on any diamonds eut, shaped and polished within the Union. ${ }^{13}$

In 1917 an important amendment was made, which altered the basis of duty from a percentage of value based on the percentage ratio of profits to revenue to a flat rate of 5 per cent. of the value of the diamonds exported, the value being defined as the true market or selling price of such diamonds within the Union at the date of export. ${ }^{13}$

At the same time, the incidence was transferred from the producer to the exporter, the duty being payable by the exporter prior to or at the time of the registration of the diamonds for export. The exporter is to render a statement speeifying to the best of his knowledge and belief the true market value or price, and the Commissioner for Inland Revenue may authorise any person deemed by him to possess the requisite knowledge, to value any diamonds liable to duty. If the valuation exceeds by 10 per cent. the value or price specified by the exporter, double duty is to be paid on that excess, and if such valuation exceeds by 20 per cent. the value or price specified, double duty is to be paid on the entire value as ascertained by the valuation. ${ }^{14}$

In 1919 a further amendment was introduced, increasing the rate of duty from 5 to 10 per cent. and rendering alluvial diamonds, which had up to that time been exempted from the export duty, liable to it. ${ }^{15}$

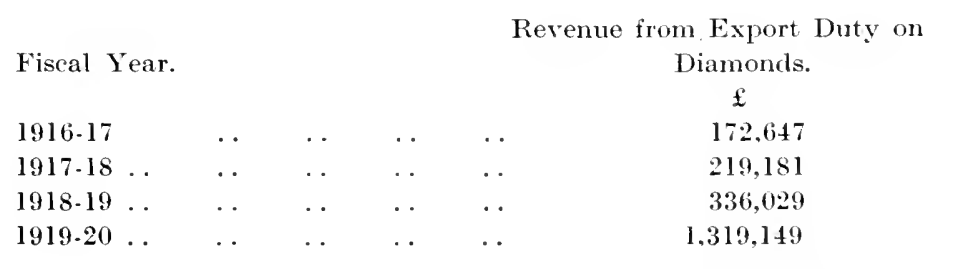

11 Act 36 of 1916 , secs. 1 and 2 .

12 Ibid, secs, 6,7 and 10 .

13 Act 27 of 1917 , sec. 3 .
14 Act 27 of 1917 . secs. 4 and 5 . 15 Act 34 of 1919 , secs. I and 2 . 
The extraordinary increase in this item of revenue in 1919-20 is to be attributed partly to the increase in the duty from 5 to 10 per cent. and partly to the enhanced prices realised for diamonds in that year.

Provincial Gold Profits Tax.-In 1918 the Transvaal Provincial Council imposed a tax upon the profits derived from the production of gold within the province of the Transvaal, provided that such profits exceeded $£ 300$ in any year. Where the gross profits exceeded 10 per cent. of the gross revenue but did not exceed 15 per cent. thereof, the rate was 1 per cent. on the net profits; and where the gross profits exceeded 15 per cent., the above rate of 1 per cent. increased by one-tenth of 1 per cent. for each additional one per cent. of such percentage of profits to gross revenue up to a maximum rate of 4 per cent. upon the net profits when the percentage of profits to revenue amounted to or exceeded 45 per cent. ${ }^{16}$

In 1921, however, legislation was passed by the Union Parliament (Act 5 of 1921) which deprived a provincial council of the power to make an ordinance which imposed direct taxation in respect of the product of, or the income or profits derived from, any mining operations or in respect of rights to mines and minerals. The Provincial Gold Profits Tax in the Transvaal, accordingly, ceased to be in operation after March 31, 192.2. ${ }^{17}$ In 1921-22 it had yielded a revenue of $£ 267,204$.

16 Transvaal Ordinance 14 of 1918 , secs. 1 and 4 . 
Estate and Succession Duties. Transfer Duty. Stamp Duties. Licences.

\section{(1) Estate and Succession Duties.}

A. On Estates of Persons who died prior to July 1, 1922.-Taxes on the estates of persons who have died within the Union and shareholders in Transvaal companies who have died outside the Union prior to July 1, 1922, are still levied under the various laws in force in the several provinces prior to the establishment of the Union in 1910. In the Transvaal the tax is raised by means of an Estate Duty chargeable on the net value of the estate of the deceased, and in the other three provinces by a Succession Duty on the value of successions accruing to heirs of a deceased person from his estate.

(a) Estate Duty in Transvaal.-Prior to July 1, 1909, this duty was leviable under the provisions of Law 15 of 1899 of the Transvaal Republic, in accordance with which a duty of one per cent. was imposed on the gross value of deceased estates. ${ }^{1}$ Subsequent to that date the duty was leviable under the Transvaal Estate Duty Act of 1909, which provided for the exemption of all estates whose net value did not exceed $£ 2,000$ and introduced a sliding scale of rates, ranging from 1 per cent. in cases where the net value of the estate exceeded $£ 2,000$ but did not exceed $£ 3,000$, to 10 per cent. on the net value of estates in excess of $£ 250,000 .^{2}$ The net value of the estate of a deceased person is to be ascertained by deducting (1) the debts and liabilities of the deceased person incurred bonafide and included in the liquidation account, (2) the funeral expenses, and (3) all costs and expenses incidental to the administration of the estate. ${ }^{3}$

The revenue varies from year to year according to the value of the estates dealt with.

Fiscal Year.

$\begin{array}{lllll}1912-13 & \ldots & \ldots & \ldots & \ldots \\ 1913-14 & \ldots & \ldots & \ldots & \ldots \\ 1914-15 & \ldots & \ldots & \ldots & \ldots \\ 1915-16 & \ldots & \ldots & \ldots & \ldots \\ 1916.17 & \ldots & \ldots & \ldots & \ldots\end{array}$

Revenue from Estate Duty.

$£$

337,612

65,233

53,913

69,720

47,257

1 Law 15 of 1899 , sec. 1.

2 Transvaal Act 28 of 1909 , Schedule.

3 Ibid, sec. 5. 
The high figure for 1912-13 is to be attributed to the death of a large foreign shareholder. In that year the value of net estates upon which estate duty was assessed amounted to $£ 4,515,316$ as compared with $£ 1,649,041$ in $1913-14$ and $£ 1,523,784$ in $1916-17 .^{3}$

(b) Succession Duty in the Cape of Good Hope, Orange Free State, and Natal.-In all three provinces the rate of duty varies in accordance with the degree of relationship, in respect of which the classification adopted in the Cape of Good Hope is identical with that prevailing in Natal, although the rates are different.

\section{Succession Dutr.}

\section{Degree of Relationship.}

(1) Lineal descendanit or ancestor

(2) Brother or sister $\quad \ldots$

(3) Descendant of brother or sister ...

(t) In any other degree of consanguinity, or stranger in blood

Cape of Good Hope.
$\%$
3
6
9

Orange Free State.

Natal.
$\%$
1
2
3
5

(1) In ascending or descending line, and husband and wife ... ... 1

(2) In the collateral line $\quad \ldots \quad \ldots \quad$, 2

(3) Stranger in blood $\quad \ldots \quad \ldots \quad$...

The administration of the laws relating to succession duty, and the responsibility for collection of the duty payable thereunder, is vested in the Masters of the Supreme Court of the Provinces of the Cape of Good Hope, Natal, and Orange Free State.

The recenue from succession is likewise subject to fluctuation from year to year. The Cape of Good Hope yields about 75 or 80 per cent. of the revenue in consequenee of the larger population and the higher rates of duty.

$$
\text { Fiscal Year. }
$$

$\begin{array}{lllll}1912.13 \ldots & \ldots & \ldots & \ldots & \ldots \\ 1913-14 & \ldots & \ldots & \ldots & \ldots \\ 1914-15 \ldots & \ldots & \ldots & \ldots & \ldots \\ 1915.16 \ldots & \ldots & \ldots & \ldots & \ldots \\ 1917.18 \ldots & \ldots & \ldots & \ldots & \ldots\end{array}$

Total Revenue irom Succession Duty.

$$
\text { f }
$$

80,269

104,024

93,565

116,466

134,453

The following table shows the total revenue from taxes on the estates of deceased persons in the Union and the relation thereof to the total ordinary revenues (Union and Provincial).

\footnotetext{
3 Report of Conmissioner for Inland Revenue 1916-17, p. 12.

5 Natal Act 35 of 1905 , sec. 2.

7 Cape Act 33 of 1908 , sec. 3 .

6 O.F.S. Law Book, ch. 68, sec. 1.
} 
Heading

Revenue from Estate and Succession

Duties ... ...

Percentage of Gross Ordinary

Revenue $\quad \ldots \quad \ldots \quad \ldots$

Per Capita of European Population

Per Capita of Total Population
1912-13. $1915-16$

£

417,881

2.4

6s. $5 \mathrm{~d}$.

1s. 4 d.
$1917 \cdot 18$

$£$

208,814

282,506

.9

2s. $11 \mathrm{~d}$. 3s. $10 \mathrm{~d}$.

7d. $\quad 91 \mathrm{~d}$.

B. On Estates of Persons who died after July 1, 1922.

The Death Duties Act of 1922 is a consolidating measure and brings about uniformity in the taxation of deceased estates within the Union. It applies only to the estates of persons who died on or after the first day of July, 1922.

The consolidation of the various laws relating to estate and succession duty in the four Provinces of the Union was a necessary procedure and a laudable achievement, since those laws overlapped and produced certain anomalies. For example, if a person died domiciled in Natal, with a farm and stock in the Cape and shares in Transvaal companies, the estate was to pay suceession duty in Natal upon the full value of the movables wherever situated and, in addition, succession duty was payable on the stoek in the Cape, and estate duty was levied also upon the shares in Transvaal companies. The great difference in rates in the several provinces was another serious anomaly.

The new death duties comprise an estate and a succession duty. The former is levied on the net value of the estate and the latter on the successions accruing to the various heirs from that estate. - For the purposes of the estate duty, the dutiable amount of any

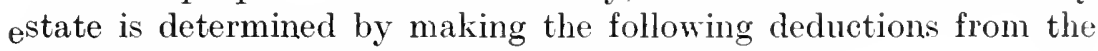
total value of all property included therein :

(a) all expenditure in connection with the death and funeral of the deceased ;

(b) all costs in the administration and liquidation of the estate :

(c) debts and liabilities of the deceased;

(d) the value of any property passing by disposition of the deceased to any public institution of a charitable, educational or ecclesiastical nature;

(e) any amount due and reeeivable under any policy of insurance upon the life of the deceased. when such amount is payable under a duly registered antenuptial or post-nuptial eontract to the surviving spouse or children : 


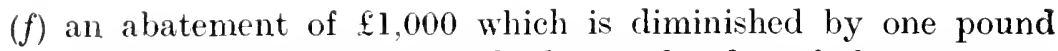
for every pound by which the total value of the property, after allowing the aforementioned deductions, exceeds $£ 1,000$; i.e. no estate duty is leviable on an estate the net value of which does not exceed $£ 1,000$.

The rates of the estate duty range from $\frac{1}{2}$ per cent. upon the first $£ 2,000$ of the clutiable amount to 3 per cent. upon so much of the dutiable amount as exceeds $£ 5,000$ but does not exceed $£ 10,000$, 10 per cent. between $£ 75,000$ and $£ 100,000$, and 17 per cent. upon so much of the dutiable amount as exceeds $£ 1,000,000{ }^{8}$

The rates of the succession duty vary aceording to the degree of relationship as follows :

Degree of Relationship.

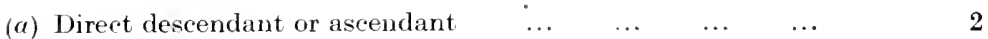

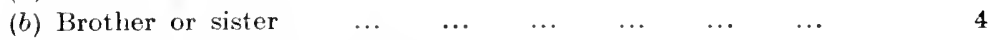

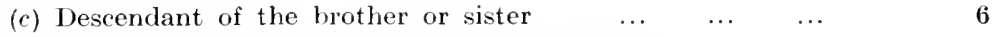

(d) Otherwise related to the deceased, or a stranger in blood, or

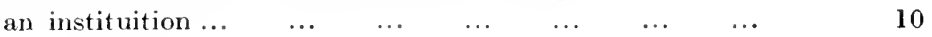

Exemption is granted in the case of the surviving spouse and public institutions of a charitable, educational or ecclesiastical nature.

The assessment of the new death duties has been transferred to the Commissioner for Inland Revenue. The Masters of the Supreme Court are to determine the dutiable amounts of the estates and of any successions and transmit statements thereof to the Commissioner. who is then to assess the duty chargeable in respect thereof; provided that if he is of opinion that any dutiable amount, as certified by the Master, does not in fact represent the correct amount upon which duty is required to be paid. he may review the account. in question and adjust such amount accordingly."

The new system of death duties is a great improvement on the old one, but in general the science of Finance approves of the graduated inheritance tax, i.e. graduated not only according to relationship but also according to the amount of the succession or inheritance, rather than of the combined estate and snceession duties. Under the latter system the estate duty is graduated aceording to amount and the succession duty according to relationship. More or less the same principle is realized in these tro varieties, but the great disadvantage of the combined system is that the estate duty 
falls entirely on the residual heir or heirs who are frequently the more significant parties involved and the most deserving of special consideration, whereas the heirs to fixed bequests or legacies are subject merely to the succession duty.

Hitherto the estate and succession duties have not by any means been an important source of revenue in the Union as in Great Britain, France and Germany, but it is to be hoped that the new system will prove to be more productive of revenue and a worthy adjunct to the income tax.

\section{(2) Transfer Duty.}

Transfer duty is imposed upon all persons purchasing or acquiring fixed property and is payable by the person acquiring such fixed property. It continues to be levied under the laws in force in the several provinces prior to Union, and the administration of these laws is vested in the Commissioner for Inland Revenue.

In accordance with the Financial Relations Act of 1913 the revenues from transfer duty were assigned to the provinces, but the power of legislation was retained by the Union Parliament. These revenues are raised and received by the Union Government, but instead of being paid into the Consolidated Revenue Fund they are paid over by the Union Treasury (without deduction for the cost of collection) to the province from which such proceeds have been raised. ${ }^{11}$

Prior to 1913 the rate of duty prevailing in the Cape of Good Hope and the Orange Free State was 4 per cent. upon the purchase price or value of any immovable property sold or otherwise alienated and transferred, ${ }^{12}$ whereas in Natal the rate was three per cent. upon the amount of the price paid or to be paid for the landed property or on the value of the land or property exchanged or alienated,$^{13}$ and in the Transvaal it was $1 \frac{1}{4}$ per cent. ${ }^{14}$ Under the Transfer Duty Reduction Act of 1913 provision was made for the reduction of the duty to 2 per cent. in the Cape of Good Hope, Orange Free State and Natal. ${ }^{15}$ The rate of $1 \frac{1}{4}$ per cent. in the Transvaal remained in force until 1919 when it was increased to 2 per cent.${ }^{16}$ thereby securing uniformity in rates in the four provinces of the Union.

The revenue from transfer duty has been subject to constant change as the result of :

11 Act 10 of 1913, sec. 13,

12 Cape Act 5 of 1884 , sec. 2, and

O.R.C. Ordinance 12 of 1906 , sec. 3.

13 Natal Ordinance 23 of 1907 , sec. 1.
14 Transvaal Ordinance 14 of 1905 , sec. 1 .

15 Act 11 of 1913 , sec. 1 .

16 Act 28 of 1919 , sec. 1 . 
(a) the reduction in the rate of the duty in 1913 ;

(b) the outbreak of the European War and the consequent disturbance in land values and land transactions;

(c) the rise in land values during the latter part of the war period;

(d) the great increase in the number of deaths occasioned by the Influenza epidemic in 1918.

Heading.

Total Revenue from

Transfer Duty ...

Percentage of Gross Ordinary Revenues ...

Percentage of Total Ordinary Provincial

Revenues $\quad \ldots \quad \ldots$

Per Capita of European Population ... ...

Per Capita of Total Popu. lation ...t
1912-13. 1913-14. 1915.16. 1917-18. 1918.19.

$£ \quad £ \quad £ \quad £ \quad f$

$\begin{array}{ccccc}523,187 & 383,626 & 235,490 & 411,864 & 554,000 \\ 3 & 2.2 & 1.3 & 1.9 & 2.3 \\ -- & 11 & 7 & 10 & 10.8\end{array}$

8s. 0d. 5s. 8d. $\quad$ 3s. 5d. 5s. 9d. $\quad 7$ s. 7 d.

1s. $8 d . \quad 1 \mathrm{~s} .2 \mathrm{~d}$. $9 \mathrm{~d}$. $\quad 1 \mathrm{~s} .2 \mathrm{~d} . \quad 1 \mathrm{~s} .7 \mathrm{~d}$.

(3) Stamp Duties.-Stamp duties are imposed upon a large variety of documents, the rates being very moderate, such as $:^{17}$

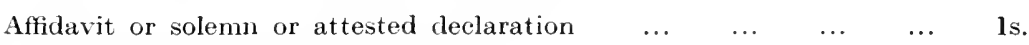

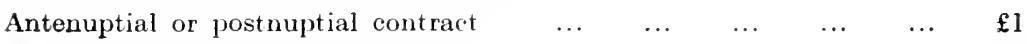

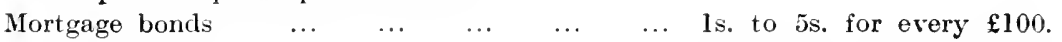

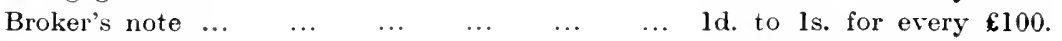
Marketable securities ... $\quad \ldots \quad \ldots \quad \ldots \quad \ldots \quad \ldots \quad 6 d$, to 2 s. for every $\mathfrak{£ l 0}$ of nominal value.

Insurance policies $\quad \ldots \quad \ldots \quad \ldots \quad \ldots \quad \ldots \quad \ldots \quad$ ld. to a maximum of $£ 5$. Transfer deed $\ldots \quad \ldots \quad \ldots \quad \ldots \quad \ldots \quad \ldots \quad \ldots \quad 6$ d. for every $£ 10$ of immov. able property.

Security or surety bond

ld. to 1s. for every $£ 100$.

The payment of stamp duties is to be denoted by means of adhesive revenue stamps of the required value affixed to the documents, or by means of impressed or embossed stamps. ${ }^{18}$

Heading.

Revenue from Stamp

Duties ... ... ...

Percentage of Gross Ord.

inary Revenue ...

Per Capita of European

Population ... ...

Per Capita of Total Popu-

lation ...
1912-13 1913-14. 1914-15.

$\mathfrak{f}$

333,096

343,971

291,236

1915-16. 1916-17.

$£ £$

$\mathfrak{f}$

$£$

$\begin{array}{ccccc}1.9 & 2 & 1.9 & 1.7 & 1.6 \\ \text { 5s. 1d. } & \text { 5s. 2d. } & \text { 4s. 3d. } & \text { 4s. 3d. } & 4 \text { s. } 6 \mathrm{~d} . \\ \text { 1s. 1d. } & \text { 1s. 1d. } & 10.9 \mathrm{~d} . & 10.7 \mathrm{~d} . & 11.4 \mathrm{~d} .\end{array}$

17 Act 30 of 1911, Second Schedule,

18 Ibid, sec. 6 (1).

and Act 31 of 1921 . 


\section{(4) Miscellaneous Duties.}

(a) Bank-note Duty.-Under the Stamp Duties Act of 1911 every bank which had the authority to issue notes within the Union was to render to the Commissioner for Inland Revenue, within one month after the end of each accounting half-year of such bank, a statement showing the amount of the note circulation of the bank during the preceding half-year, and was at the same time to pay duty thereon at the rate of $10 \mathrm{~s}$. per $£ 100$ of the amount of the average monthly circulation during the half year. ${ }^{19}$

\begin{tabular}{ccccccc} 
Fiscal Year. & & & & \multicolumn{3}{c}{$\begin{array}{c}\text { Revenue from } \\
\text { Bank-note Duty. 2" } \\
\mathfrak{E}\end{array}$} \\
& & & & & & \\
1912.13 & $\ldots$ & $\ldots$ & $\ldots$ & $\ldots$ & $\ldots$ & 23,021 \\
$1914-15$ & $\ldots$ & $\ldots$ & $\ldots$ & $\ldots$ & $\ldots$ & 21.910 \\
$1915-16$ & $\ldots$ & $\ldots$ & $\ldots$ & $\ldots$ & $\ldots$ & 26,278 \\
$1916-17$ & $\ldots$ & $\ldots$ & $\ldots$ & $\ldots$ & $\ldots$ & 28.141 \\
1917.18 & $\ldots$ & $\ldots$ & $\ldots$ & $\ldots$ & $\ldots$ & 39,781
\end{tabular}

The increase in this item of revenue after 1914-15 reflects the increase in paper money.

The Currency and Banking Act of 1920, however, vested the sole right to issue bank notes in the Central Reserve Bank for a period of 25 years, and this bank is exempt from the payment of any tax or duty upon its note issues, other than a graduated tax levied in the case of suspension of the reserve requirements at the following rates :

One per cent. per annum when the gold reserve against notes is less than 40 per cent, but not less than $32 \frac{1}{2}$ per cent. ; and, in addition,

$1 \frac{1}{2}$ per cent. per annum upon each $2 \frac{1}{2}$ per eent. decrease by which the reserve falls below $32 \frac{1}{2}$ per cent.

(b) Companies' Capital Duty.-A statement of the amount which is to form the nominal share capital of any company to be registered under any law relating to the registration of companies, and a statement of the amount of any inerease of share capital of any eompany, is to be delivered to the receiver of revenue before the registration, and upon every such statement there is to be paid a duty of 5s. for every $\mathfrak{f} 100$ of the amount of such capital, or increase of eapital, as the case may be. ${ }^{21}$

\footnotetext{
19 Act 30 of 1911 , sec. 8 .

20 Report of Commissioner for Inland

Revenue 1917.18, p. 6 .

21 Act 30 of 1911 , sec. 13 .
} 
Fiscal Year.
Revenue from Companies'

Capital Duty. ${ }^{20}$

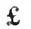

$\begin{array}{rlllllr}1912.13 & \ldots & \ldots & \ldots & \ldots & \ldots & 12,780 \\ 1914-15 & \ldots & \ldots & \ldots & \ldots & \ldots & 8,250 \\ 1916-17 & \ldots & \ldots & \ldots & \ldots & \ldots & 12,774 \\ 1917.18 & \ldots & \ldots & \ldots & \ldots & \ldots & 32.213\end{array}$

The considerable enhancement of the revenue in 1917-18 indicates the activity in respect of the registration of new companies and the increase in the capital of existing companies.

(c) Insurance Coupon Duty.-This is a duty of $2 \frac{1}{2}$ per cent. on the annual receipts from the sale or issue of any tickets, coupons, notices, bills, or other documents purporting to be, or to entitle to, an insurance in the event of death, injury, slekness, or the like. ${ }^{22}$

\section{Fiscal Year.}

Revenue from Insurance

1912.13

1914.15

1916-17

1917.18

\section{Coupon Duty.}

$\mathfrak{f}$

29

33

45

47

\section{(5) Licences.}

In accordance with the provisions of the Financial Relations Act, the following distribution of the revenue from licences between the Union and the Provinces was effected.

In the first place, certain trading and rocational licences were reserved to the Union. such as licences to carry on the calling of a commercial traveller or of an agent representing in the Union any foreign business undertaking, or to carry on business as a joint stock company, banker, banking company, insurance company, or a building, friendly, and provident society, or to import, export, manufacture, deal in or be in possession of arms and ammunition, or for prospecting and mining for minerals. ${ }^{23}$

Secondly, all other licences in respect of the exercise of any trade, business, vocation or profession were transferred to the Provinces in 1913, together with licences for dogs outside urban areas, licences to catch or kill game, fish. or other animals, and motor-car licences. The power of legislation in connection with these licences was likewise transferred to the Provinces. ${ }^{24}$ 
Thirdly, the revenue from liquor licences was assigned to the Provinces, but the right to legislate in respect thereof was retained by the Union Parliament. ${ }^{25}$

Head of Revenue. 26

A.-Union Licences

B.-Provincial Licences :
$1913 \cdot 14$. $\mathfrak{f}$ 130,006

129,369

198,195

129,246

185,471

126.491

246,574

130,592

(b) General Licences ...

(c) Dog, Fish and Game

(d) Motor-car Licences

$\begin{array}{r}45,852 \\ 17,451 \\ 11,936 \\ \hline\end{array}$

Total

43,106

21,322

62,058

27,329

4.434

$\overline{\mathfrak{1} 492,690}$
9,038

583,205
1917.18. 1919.20.

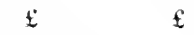

126,095

The following table will serve to indicate the fiscal significance of licences and the per capita revenue from licences.

Heading.

Total Revenue from Licences

Percentage of Total Ordinary Revenue...

Per Capita of European Population ...

Per Capita of Total Population
$1913 \cdot 14$.

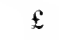

532,809

3

8s. $0 \mathrm{~d}$.

1s. $8 \mathrm{~d}$.
$1915 \cdot 16$.

£

492,690

2.8

7s. 2 d.

Is. $6 \mathrm{~d}$.
1917.18.

$\mathfrak{E}$

525,422

2.4

7s. $4 \mathrm{~d}$.

¿5 Ibid, sec. 13. 
CHAPTER 12.

Native Taxes. Layd Tax. Hocse Tax. Miscellaneous Provincial Taxes.

(1) Native Taxes.

(a) Hut and Poll Taxes.-In the Transvaal and Orange Free State a poll tax is imposed, whereas in Natal and the Cape of Good Hope a hut tax has been adopted in respect of the taxation of natives. In the Transvaal an annual poll tax of $£ 2$ is levied on each adult male native, with a further tax of $\mathfrak{£} 2$ on every native with more than one wife. Native farm labourers and natives in municipal locations are allowed a reduction of $f l$ each in respect of their tax liability. In the Orange Free State an annual poll tax of $£ 1$ is levied on each adult coloured person. In the Cape of Good Hope, on the other hand, a hut tax is levied on natives at the rate of $10 \mathrm{~s}$. per hut, in Natal at $14 \mathrm{~s}$. per hut, and in a small area of the Orange Free State at $£$ per hut. ${ }^{1}$

The collection of the hut tax in the Cape and Natal is undertaken by magistrates and superintendents of locations. The poll tax in the Transvaal is collected by magistrates, sub-native commissioners, and pass officers, and in the Orange Free State by non-commissioned officers of the police. ${ }^{2}$

Taking into consideration the great preponderance of the native over the European population, the revenue derived from these native taxes by the Union Treasury constitutes an insignificant item. The poll tax is in its nature more productive than a hut tax. The Transvaal poll tax alone yields slightly more than one-half of the total revenue from native taxes within the Cnion, as for example, $£ 417,445$ out of $£ 792,695$ in $1914-15$ and $£ 416,524$ out of $£ \$ 19,890$ in 1916-17, whereas the native population of the Transvaal represents merely 30 per cent. of the total native population of the Union. The native population in the Cape is larger than that in the Transvaal, whereas the native revenue yielded by the Cape hut tax is generally less than 30 per cent. of the vield of the Transvaal poll tax. This is due partly to the higher rate prevailing in the Transvaal and partly to the fact that in the Transvaal the basis of such taxation is 
the adult male native, whereas in the Cape and Natal it is the hut which may contain several adult male natives or which may be abandoned as the usual habitation by large numbers of natives as they rise in the scale of civilization. If the Transvaal poll tax is applied to the other provinces, the native revenues would be considerably enhanced.

(b) Native Pass Fees.-In aeeordance with the provisions of the Financial Relations Act of 1913, the pass fees payable by the employers of natives in the labour districts of the Transvaal were assigned to that province, but the power of legislation was retained by the Union Parliament. These fees are collected under the authority of the Union Parliament, but instead of being paid into the Consolidated Revenue Fund they are assigned by the Union Treasury to the provincial revenue fund of the Transvaal.

Native pass fees are also eolleeted in the other provinces, and these, together with certain pass fees eollected in the Transvaal, are paid into the Consolidated Revenue Fund. However, the great bulk of the pass fees is collected from the employers of natives in the labour areas of the Transvaal and assigned to that provinee, the Union share of pass fees constituting an item of comparative insignificance. Prior to 1913 all native pass fees were paid into the Union Treasury, but subsequent to that year the distribution between the Union and the Province of the Transvaal was effeeted in accordance with the Financial Relations Act.

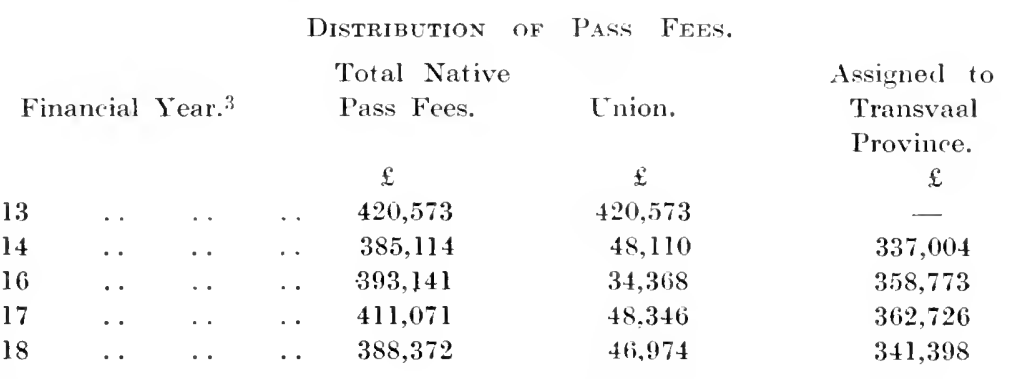

The variations in the revenue are mainly dependent on the number of natives employed in any particular year in the labour and municipal areas in the Transvaal, and also on the activity of the diamond industry in the Cape and the Orange Free State.

The pass fees represent on an average about 25 per cent. of the total revenue of the Province of the Transvaal.

\footnotetext{
3 Reports of Commissioner for Inland Revenue for 1916-17 and 1917-18, pp. 14 and 9 respectively.
} 


\begin{tabular}{|c|c|c|c|c|c|}
\hline Heading. & $\begin{array}{c}1911-12 . \\
£\end{array}$ & $\begin{array}{c}1913 \cdot 14 . \\
£\end{array}$ & $\begin{array}{c}1915 \cdot 16 . \\
f\end{array}$ & $\begin{array}{c}1917-18 \\
\mathfrak{f}\end{array}$ & $\begin{array}{l}1919-20 \\
f\end{array}$ \\
\hline $\begin{array}{c}\text { Revenue from } \\
\text { Taxes }\end{array}$ & $1.182,246$ & $1,195,816$ & $1,222,504$ & $1,210,325$ & $1,222,152$ \\
\hline $\begin{array}{c}\text { Percentage of Gross } \\
\text { Ordinary Revenue . }\end{array}$ & 6.8 & 6.8 & 6.9 & 5.7 & 4.1 \\
\hline Per Capita of Native & & & & & \\
\hline $\begin{array}{lll}\text { Population } & \text {. } & \end{array}$ & 5s. $10 \mathrm{~d}$ & 5s. $8 \mathrm{~d}$. & $5 s .6 \mathrm{~d}$. & 5s. 3d. & 5s. Id. \\
\hline
\end{tabular}

Land taxes are imposed only in the Transvaal and the Orange Free State and in three distriets in Natal-the three old Transvaal districts which were annexed to Natal.

In the Transvaal and Orange Free State a direet land tax on all farms within those provinees is levied. The rates are fixed aceording to the extent, and no aceount is taken of the value. The rates in force in the Transvaal are as follows:

Quitrent tenure-ls. 6d. per 100 morgen $^{5}$ or portion thereof in the ease of surveyed farms, and in respeet of unsurveyed farms $30 \mathrm{~s}$. for a whole farm or portion more than half, and $15 \mathrm{~s}$. for a half portion or less.

Freehold tenure-10s. for a whole farm not exceeding 3,750 morgen, with an additional 2s. 6d. per 100 morgen for any extent in excess of 3,750 morgen, and 5 s. for a half farm which is not more than 1.875 morgen, or for any portion less than half.

If the registered owner is domiciled ontside the Transvaal, the land tax in respect of quitrent farms is doubled.

The trouble and expense of colleeting this land tax are out of all proportion to the amount colleeted. A large amount of arrear taxes exists, due in many instances to the land being dereliet and the whereabouts of the owners being unknown. The Commissioner for Inland Revenue has been disinelined to take proceedings for the sale of the land as the tax outstanding in each ease is generally under $£ 10 .^{6}$

In the Orange Free State the rate is $2 \mathrm{~s}$. per 100 morgen or portion thereof, the area of unsurveyed farms being estimated according to the report of the Land Commission. An additional amount of $£ 5$ per annum is payable on each farm belonging to persons resident outside the province and not oeeupied. This tax is payable on the

\footnotetext{
4 Ibid, pp. $15-16$.

5 A morgen is the equivalent of ap. proximately $21 / 9$ acres.

6 Report for $1916 \cdot 17$, p. 15.
} 
31 st December of each year, and if not paid by the 31st March following, a fine equal to the amount in arrear is imposed. This provision greatly facilitates eollection and consequently there are very few arrear taxes.

In three districts of Natal the following land tax is in foree :

Quitrent farms-annual quitrent of 1s. 6d. for every 100 morgen or portion thereof.

Freehold farms-annual quitrent of $31 / 5 \mathrm{~d}$. for every 100 morgen or portion thereof.

Heading.

$\begin{array}{lrr}\text { Revenue from Land } \\ \text { Taxes .. } & . . & . . \\ \text { Percentage of Gross } & \text { Ord. } \\ \text { inary Revenue } & . . \\ \text { Per Capita of European } \\ \text { Population } & \text {. } \\ \text { Per Capita of Total Popu- } \\ \text { lation .. } & \text {.. } & \text {.. }\end{array}$
$1912-$

$£$

40,856

.23

$7 \mathrm{~d}$.

$1.6 \mathrm{~d}$.
$1913 \cdot 14$

$\mathfrak{L}$

38,385

$.2 \cdot 2$

6.9d.

$1.5 \mathrm{~d}$.
1914-15.

£

34,806

.22

6. $2 \mathrm{~d}$.

$1.3 d$.
1915-16. 1916-17.

$\mathfrak{E}$

£

$40,881 \quad 40,124$

.23

.20

7d. $6.9 \mathrm{~d}$.

$1.5 \mathrm{~d} .1 .4 \mathrm{~d}$.

These land taxes were inherited from the pre-Union period and yield a negligible revenue on account of the exceedingly low rates. Attempts have been made by the urban representatives in the Union Parliament to introduce a national land tax that will yield sufficient revenue to secure relief in respect of taxation for urban interests, but so far the numerical strength of the rural representatives in Parliament has been able to prevent it.

(3) House Tax.

The house tax prevailed only in the Transvaal where it was introduced by the Provincial Comeil in 1917. It was a tax on the occupiers of all dwelling-houses within the provinee. The rates as prescribed in the initial House 'Tax Ordinanee were as follows:

(a) in respect of dwelling-houses containing four rooms and not more than twelve rooms, the rate was 5s. for each room;

(b) in respect of dwelling-houses containing more than twelve rooms, 5s. for each room up to twelve and in addition 2s. 6d. for each room in excess of twelve rooms."

In 1918 an alteration was made in respect of the rates, a flat rate of $5 \mathrm{~s} .{ }^{9}$ for each room irrespective of the number being instituted.

In cases where a dwelling-house was occupied in separate

7 Ibid, p. 16 .

8 Transvaal Ordinance 19 of 1917 , Schedule.
9 Transval Ordinance 16 of 1918 , sec. 3 . 
parts as lodgings, flats, or tenements, the person granting the right of occupation thereof was deemed to be the occupier of every room in such dwelling-house. ${ }^{11}$

Exemptions were provided for in farour of the following dwelling houses :

(a) dwelling-houses unocenpied during the whole period of 12 months for which the tax is payable;

(b) dwelling-houses occupied as hospitals and aided by the State, charitable institutions, and school boarding-houses;

(c) dwelling-houses not of European construction and occupied exclusively by natives;

(d) dwelling-houses oeeupied by widows or single women not liable to the Union normal income tax. ${ }^{11}$

The revenue derived from the house tax in the Transvaal, during the first year of its operation, namely 1917 - 18 , amounted to $£ 73,102,{ }^{12}$ or 4.8 per cent of the total revenue of the Transvaal Provincial Administration (i.e. ineluding the subsids from the Unior Government). It was repealed in 1920 .

\section{(4) Miscellaneous Provincial Taxes.}

(a) Wheel Tax.-The wheel tax was adopted by the Transvaal and the Orange Free State in 1916, and by Natal in 1918. In the Transvaal the rates are as follows:

On any vehicle, not being a bicycle or tricyele, $7 \mathrm{~s}$. $6 \mathrm{~d}$. per wheel;

On any bicycle or tricycle. 2s. 6d. ${ }^{13}$

In the Orange Free State the rate is 2s. $6 \mathrm{~d}$. per wheel in the case of any vehiele, not being a bieycle, and $9 \mathrm{~d}$. per wheel in the case of a bicrcle, ${ }^{14}$ the rates having been redueed from $5 \mathrm{~s}$. and $1 \mathrm{~s}$. 6d. respeetively in 1917. In that year also it was enaeted that the proeeeds of the wheel tax levied and eollected in any Magisterial District are to be alloeated to the road districts within that magisterial district and expended solely for the construetion, maintenance and repair of roads.

In Natal the rates of the wheel tax are:

10s. per wheel in respect of motor cars, motor lorries and traction engines not exceeding $1,500 \mathrm{lb}$.;

15 s. per wheel in respect of such vehicles when exceeding 1,500 lbs. but not exceeding $2,000 \mathrm{lb}$. ;

10 Ibid. sec. 5.

11 Transvaal Ordinance 16 of 1918 , Sichedule.

12 Half-yearly Abstract of Union Statistics. June 1919, p. 81.

\footnotetext{
13 Transvaal Ordinance 11 of 1916 , ser. 3.

14 O.F.S. Ordinance 11 of 1917 , sec. 2.
} 
20s. per wheel in excess of $2,000 \mathrm{lb}$.;

$2 \mathrm{~s}$. $6 \mathrm{~d}$. per wheel in respect of every other vehicle. ${ }^{15}$

In 1916-17 the revenue derived from the wheel tax in the Transvaal and the Orange Free State amounted to $f 99,799$, and in 1917-18

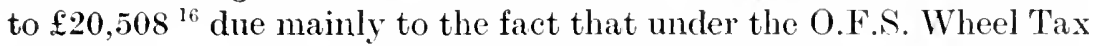
Ordinance of 1917 the receipts from the wheel tax in that province were to be allocated to the road districts for road expenditures. In 1921-22 the revenue from this source was $£ 48,081$.

(b) Totalisator Tax.--In accordance with the Financial Relations Act of 1913, the tax payable under the Transvaal law upon the takings of any instrument, machine or contrivance used in connection with betting or races (commonly known as a totalisator) doy the licensee thereof, was transferred to the provincial administration of the Transvaal. ${ }^{17}$

In 1914 the Cape Provincial Conncil introduced a similar tax at the rate of 40 per cent. of the amount of the totalisator commission deducted by the licence holder. such commission not to exceed 10 per cent. of the gross takings of each licensed totalisator. ${ }^{18}$ In 1918 the Natal Provincial Conncil likewise passed an ordinance providing for a tax on totalisators. Under this ordinance every club or person conducting a totalisator is to pay a tax of 4 per cent. on the total amount paid in to the totalisator in connection with any race meeting, provided that where such amount does not exceed $\mathfrak{E} 1,000$, the tax payable is to be equal to $2 \frac{1}{2}$ per cent. on the total amount paid in. ${ }^{13}$

The revenue derived from the totalisator tax by the provinces during the period from 1913-14 to 1919-20 was as follows:

\begin{tabular}{|c|c|c|c|c|c|}
\hline Fiscal Year & & & & & $\begin{array}{c}\text { Revenue from Totalisator } \\
\text { Tax. }{ }^{20} \\
£\end{array}$ \\
\hline $1913-14$ & . & . & . & . . & $31.56 \mathrm{~s}$ \\
\hline $1915-16$ & . & . & .. & . & 32.694 \\
\hline 1917.18 & $\ldots$ & . . & .. & . . & 60,109 \\
\hline 1919.20 & . & . & . . & . & 159.230 \\
\hline 1921.22 & $\ldots$ & .. & .. & .. & 112,986 \\
\hline
\end{tabular}

(c) Entertaimment Tax.-Prior to 1917 the only entertainment tax in force in Sonth Africa was a tax on the buildings or open spaces used for the purpose of entertainment, in the Cape Province. This

\footnotetext{
15 Natal Ordinance 13 of 1918 , sec. 2.

16 Half-yearly Abstract of Union Statistics, June 1919 , p. 81 .

17 Act 10 of 1913 , sec. 15 \& Schedule.
18 Cape Ordinance 8 of 1914 , sec. $8(4)$.
19 Natal Ordinance 12 of 1918 ,
20 O.Y.B. 1920 . sec. 33 (I).
} 
tax was of the nature of a lieence and yielded a small revenue of about $£ 3,000$ per annum.

In 1917 the O.F.S. and Natal Provincial Councils imposed a tax upon payments for admission to entertainments. In the Orange Free State the rates are as follows : ${ }^{11}$

Where the payment does not exceed ls. . . . . . . . . . 1 . exceeds 1s. Od. but does not exceed 2s. Od. .. 2 d.

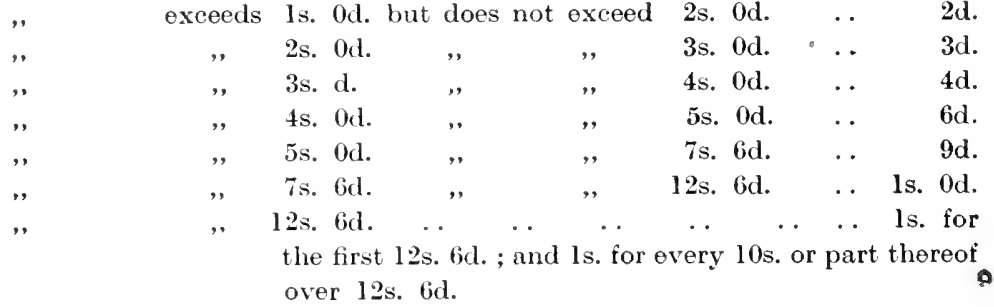

In Natal the rates of the entertainment tax are slightly different :

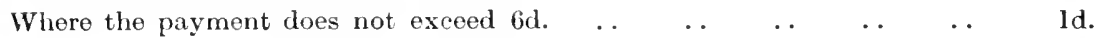

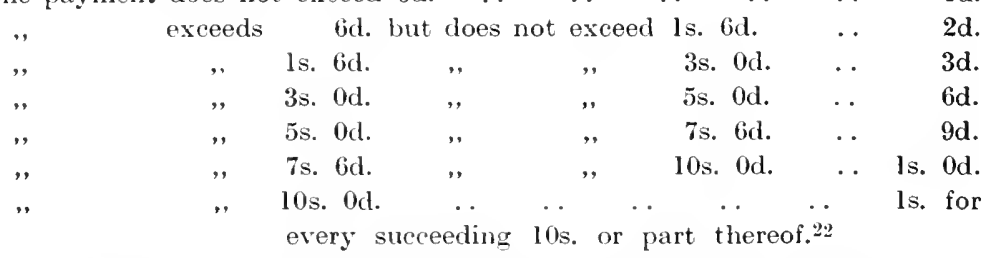

In 1918 the Cape Provincial Council followed the example of the two abovementioned Provincial Councils and introduced an entertainment tax, which was identieal with the Natal tax in all respects. ${ }^{23}$

The revenue from the provincial entertainment tax was very small until 1917-18, the first financial year in which the tax upon payments for admission to entertainments came into force in Natal and the Orange Free State.

\begin{tabular}{|c|c|c|c|c|}
\hline Fiscal & Year. & & & $\begin{array}{c}\text { Revenue from Entertainment } \\
\text { Tax. } \\
£\end{array}$ \\
\hline $1913-14 \ldots$ & $\ldots$ & . & $\ldots$ & 2,535 \\
\hline $1915.16 \ldots$ & $\ldots$ & .. & . & 2,632 \\
\hline $1917-18 \ldots$ & . & .. & $\ldots$ & 9,372 \\
\hline $1918.19 \ldots$ & .. & $\ldots$ & $\ldots$ & 56,907 \\
\hline $1919.20 \ldots$ & . & . & . & 79,706 \\
\hline $1921-22 \ldots$ & $\ldots$ & . & $\ldots$ & 99,487 \\
\hline
\end{tabular}

(d) Bachelor Tax.-In 1917 the Transvaal Provincial Council imposed a poll tax of $£ 1$ on every adult baehelor (other than a

21 O.F.S. Ordinance 6 of 1917 , sec. $2 . \quad 25$ Cape Ordinance 5 of 1918.

22 Natal Ordinance 11 of 1917 , sec 1. 
native) over the age of 21 years and ordinarily resident in that province. ${ }^{24}$ In 1918 an amendment was made in respect of bachelors over the age of 25 years, who were rendered liable to a tax of $\mathfrak{2} \mathrm{per}$ annum. ${ }^{23}$

Exemptions werc provided for in favour of the following bachelors :26

(1) bachelor's liable to the provincial house tax;

(2) bachelors who as students attend any recognised educational institution ;

(3) bachelors and widowers over 70 years of age ;

(4) Natives.

The revenue derived from the bachelor tax in the province of Transvaal, during the first year of operation, namely 1917-18, amounted to $\$ 19,024,2 \tau$ or 1.2 per cent. of the total revenue of that province. The bachelor tax was repealed in 1920 and the poll tax introduced in 1921 .

(e) Bookmaker Tax.-In 1917 a bookmaker tax was instituted in the province of the Transvaal. It is a tax payable by every bookmaker at the rate of $2 \frac{1}{2}$ per cent. on the gross amount of any money, security, or valuable thing paid or given by such bookmaker in fulfilment of any bet made by him with any person. ${ }^{2 s}$

In 1920 a similar tax was imposed in the Cape Province, at the rate of $2 \frac{1}{2}$ per cent. on the net winnings of every bookmaker upon each horse race run on a race day. ${ }^{29}$

The revenue from the bookmaker tax in the Transvaal in 1917-18, its first year, was $£ 13,243,,^{2 \pi}$ and in 1921-22, $£ 74,844$ altogether.

(f) Admission to Racecourse Tax.-The year 1917 also witnessed the imposition in the Transvaal of a tax of 20 per cent. on all payments made by persons in respect of admission to a raccourse on a day on which a racc meeting was being held. The revenue from this tax in 1917-18 was $\mathfrak{f} 3,462,{ }^{27}$ and in $1921-22, \mathfrak{f} 13,334$.

(g) Auction Tax.-This tax prevailed only in the Orange Free State, and in accordance with the provisions of the Financial Relations Act of 1913 it was transferred to that province. The revenue from the auction tax constitutes an item of comparative

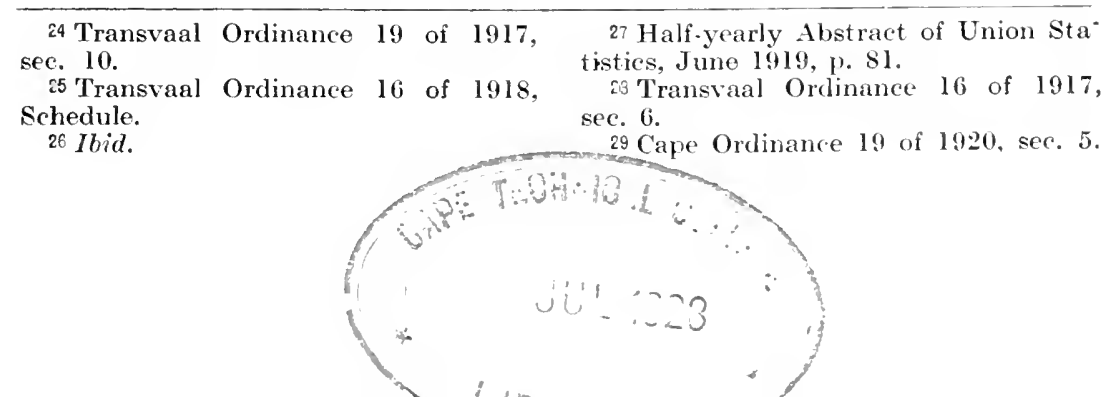


significance in the budget of the Orange Free State. (It has also been introduced in Natal recently.)

Heading.

Revenue from Auction Tax ..
1913-14.

$£$

17,892

3.5
$1915 \cdot 16$.

$\mathfrak{£}$

10,731

2.3
$1916 \cdot 17$

$\mathfrak{E}$

15,914

2.9

4.1

Revenue of O.F.S. Province (including Union Subsidy) . . . .

(h) Tax upon Immovable Property.-In 1918 the Cape Provincial Council imposed a tax on all immovable property, at the rate of three-eightlis of a penny for every $£ 1$ of the amount of the taxable value of the property. The tax is to be levied upon the valuation of the property as shown in the Provincial Valuation Roll. ${ }^{30}$ This tax yielded $£ 158,206$ in $1918-19$ and $£ 196,587$ in $1919-20$, declining to $£ 149,030$ in $1921-22$.

(i) Tax on Companies.-In 1920 an ordinance was passed in the Cape Province, providing for a tax on companies registered or carrying on business in the province, at the rate of 1s. for every $£ 100$ of market value of paid-up share capital. In cases, however, where the market value is not ascertainable, the nominal value of the paid-up capital is to be the basis of assessments. ${ }^{31}$ In $1921-22$ it yielded $£ 18,085$ in revenue.

(j) Tax on Crayfish Canning Companies.-In 1920 provision was also made, in the Cape Province, for a tax on companies carrying on the business of canning crayfish within the provinee, at the rate of 3 per cent. on the gross amount received by any such company from the sale of any tinned or eanned crayfish after deduction of 20 per cent to cover freight. insurance, exchange, broker's commission and minor sundry charges. ${ }^{32}$

(k) Tax on Increment in Land Values.-In 1919 the Transvaal Provincial Council authorised the imposition of an "increment value duty" in respect of the profit realised on the sale, cession, exchange, or any other disposal of fixed property. Where the ratio of profit to aggregate cost exceeds 5 per cent. but does not exceed 10 per cent., the rate of duty is 5 per cent., which increases by one per cent. for every 5 per eent. inerease in the profit up to and ineluding 50 per cent. increase in the profit, and thereafter the rate of duty increases by 1 per eent. for every 10 per cent. increase in the profit up to a maximum duty of 25 per cent. ${ }^{.33}$

30 Cape Ordinance 6 of 1918 , secs $1 \& 4$. 31 Cape Ordinance 17 of 1920 , sec. 3 .

32 Cape Orclinance 18 of 1920 . sec. 2
33 Transvaal Ordinance 5 of 1919 . see. 2. 
The amount of duty is subject to an abatement of $2 \frac{1}{2}$ per cent. in respect of each completed year from the date of acquisition. ${ }^{3 t}$

Exemptions have been provided for in favour of the following cases :

(1) every disposal of fixed property by a person who became entitled thereto by way of legacy or inheritance;

(2) every disposal of fixed property by an eeclesiastical, charitable or educational institution of a public eharaeter. ${ }^{35}$

Taxes have also been imposed on Tattersalls in the Transvaal, on betting in the Cape and Natal, and on professions in the Cape. The education tax was introduced in the O.F.S. in 1921, and the employers' tax in the Transvaal in 1922.

From the foregoing survey of provincial taxes proper, i.e. taxes actually levied by the Provinces in contrast to those levied by the Union Government but the proceeds of which are handed over to the Provinces, it will be observed that the Provinces have taken recourse to a great variety of small taxes in their search for additional revenue to cope with the rapid increase in their expenditures, especially those on education and hospitals, the former having risen from $£ 1,640,708$ in $1911-12$ to $£ 4,563,291$ in $1919-20$ and the latter from $£ 234,180$ to $£ 507,274$. The Union subsidies (with the exception of the special subsidies) are limited to one-half of the normal or recurrent expenditure of the respective Provinces, provided that, if the normal expenditure for any year exeeeds that of the previous year by more than 15 per cent. in the case of primary and secondary education and 5 per cent. in respect of any other matter, that Province is entitled to one-third only of that excess; so that the Provinces have to provide for a portion of the increase in their expenditures by new taxation or by a rise in the rates of existing taxes. In 1915-16 provincial taxation provided merely

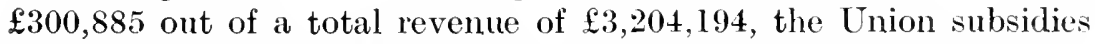
amounting to $£ 2,069,628$ and the remainder being accounted for by the so-called assigned revenues, i.e. revenues assigned to the Provinces by the Union Government such as transfer duties, liquor licences and native pass fees, and by miscellaneous receipts and fees. In 1919-20, however, provincial taxation yielded $£ 1,614,719$ out of a total revenue of $£ 7,058,715$ or 23 per cent., as compared with $9 \frac{1}{2}$ per cent. in 1915-16.

34 Ibid, sec. 3 . 35 Ibid, sec. Iti. 


\section{4}

\section{REVENUES.}

Provincial taxation has been considerably extended in recent years, although the extension has been more in the form of a multiplication of a scries of insignificant taxes than in the development and exploitation of existing taxes. The Cape of Good Hope and Transvaal, especially, have been very active in this respect. The system of taxation in the Provinces, considered in conjunction with Union and local taxation, needs to be revised and consolidated. 


\section{PART III.}

\section{PUBLIC DEBT.}

Public Debt of Colonies.

At the establishment of the Union in 1910, the public debt of the four constituent Colonies amounted to $£ 116,036,978$, of which $£ 52,566,034$ was allocated to the Cape of Good Hope, $£ 32,317,592$ to the Transvaal, $£ 22,220,943$ to Natal, and $£ 8,932,409$ to the Orange Free State. ${ }^{1}$ The greater part of this debt was elassed as reproductive, namely, $£ 80,000,000$ or about 69 per cent. of the total, and of this about $£ 75,000,000$ was asiigned to railways and harbours.

In aceordance with the provisions of the South Africa Act, the Union Government assumed all the debts and liabilities of the Colonies included in the Union; and in return all stocks, eash. bankers' balances, securities. crown lands, publie works, movable and immovable property. rights in mines and minerals, and all rights in connection with the "searching for, working for", or disposing of minerals or precious stones." which were vested in the Governments of the Colonies, were assigned to the Union Government. The annual interest of the public debts of the Colonies and any sinking funds eonstituted by law at the consummation of the Union were to form a first eharge on the revenues of the Union."

The following table indicates the nature of the capital expenditure and indebtedness of the Colonies on May 31, 1910.

Public Debt of Colonies at the time of Union. Item of Expenditure.

Amount. $\mathfrak{t}$

Railways

$6 \cdot 4,006,479$

Harbours

War and Defence.

Repatriation

Deficiency in Revenue

Lands, Agriculture and Irrigation

Public Works and Building

New Territory and Liability of Territory Annexed.

Miscellaneous

$\begin{array}{llll}\ldots & \ldots & \ldots & \ldots \\ \ldots & \ldots & \ldots & \ldots \\ \ldots & \ldots & \ldots & \ldots \\ \ldots & \ldots & \ldots & \ldots \\ \ldots & \ldots & \ldots & \ldots \\ \ldots & \ldots & \ldots & \ldots \\ \ldots & \ldots & \ldots & \ldots \\ \text { nexed } & \ldots & \ldots & \ldots \\ \ldots & \ldots & \ldots & \ldots\end{array}$

$0,074,422$

$10,538,647$

$6,584,514$

$4,470,491$

$4,462,665$

$3,926,059$

$\mathbf{3}, \mathbf{4 9 6 , 5 6 8}$

$5,448,896$

Total Expenditure

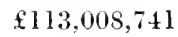

Total Expenditure

$113,005,741$

Unexpended Balances

$\begin{array}{lllll}\ldots & \ldots & \ldots & \ldots & . \\ \ldots & \ldots & \ldots & \ldots & .\end{array}$

$3,028,237$ 
Public Melst of L mion.

The gross debt of the Union was increased by about 50 per cent. during the decade from 1910 to 1920 . from $£ 116,036,978$ to

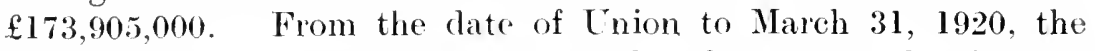
expenditures from loan funds amounted to $£ 73,079,601$, but in view of the so-called loan revenues. i.e. receipts payable into the Loan Account such as recoveries of advances to irrigation boards or settlers and the proceeds from the gold mine leases, or from the sale of war material or of Crown lands, and the occasional application of moneys out of the Sinking Fund toward the redemption of

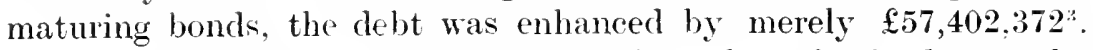

The great bulk of the expenditure from loan funds during the decade under review was incurred in connection with the war and the railways and harbours, as indicated in the following table.

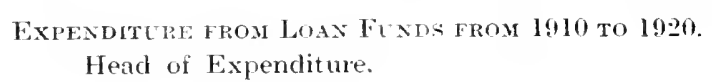

Amount.

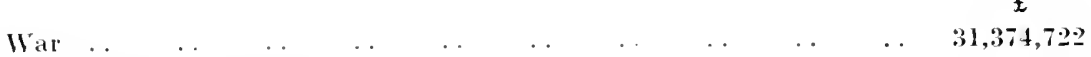

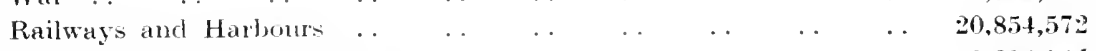

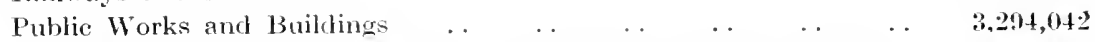

Loans to Provincial Administrations, Local Authorities, Colleges, etc. 4,414,651

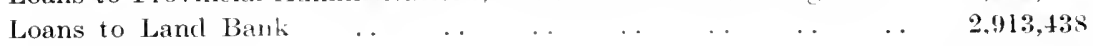

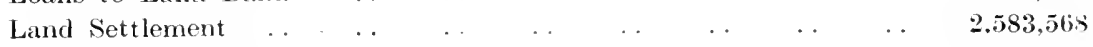

$\begin{array}{lllllllllll}\text { Irrigation } & \ldots & \ldots & \ldots & \ldots & \ldots & \ldots & \ldots & \ldots & \ldots & \mathbf{2}, 871,801\end{array}$

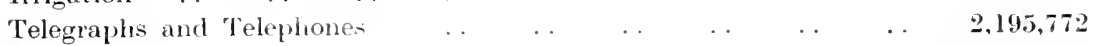

$\begin{array}{lllllllllll}\text { Miscellaneons } & \ldots & \ldots & \ldots & \ldots & \ldots & \ldots & \ldots & \ldots & \mathbf{2 , 5 7 7 , 0 3 3}\end{array}$

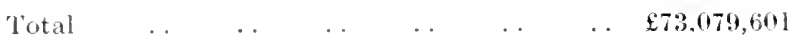

The war expenditures repiesent ahout 43 per cent. of the total outlays from loan funds and, together with the other items of unproductive expenditure such as those public works and buildings that are not used for commercial purposes, the deficit of $\mathfrak{2} 2,012,465$ for the financial year $1914-15$ which is included under miscellaneous expenditure, etc., constitute about one-half of the total cxpenditure; so that, with a fair degree of accuracy. one-half of the gross expenditure from loan funds during the first decade of the Union may be classified as reproductive, and the other half as inproductive. The unproductive expenditure, however, is considerably diminished by deducting therefrom the proceeds from the sale of war material (amounting to sereral million pounds) and the revenues which were assigned to the Loan Account 
to meet war expenditure, such as the proeecds from the gold mine leases, the sale of Crown lands. and the exeess profits tax (in the years 1917-18 and 1918-19).

No aecurate computation ean be made as to the proportion of the public debt which may be classified as reproduetive. An examination of the main heads of expenditure from loan funds does render it possible to secure approximate figures, but the financial system in vogue does not permit of statistieal precision. The statements of the public debt of the Union show only expenditures from loans which are still in existence at the time, and do not aceount for such expenditures as have been paid out of the loan revenues or made from loans which have been redeemed. For example. during the decade from 1910 to 1920 the expenditure. from loan funds amounted to

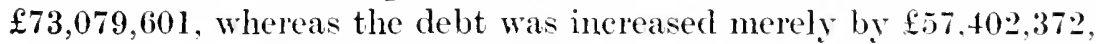
leaving a difference of $\mathfrak{f 1 5 , 6 7 7 , 2 2 9}$ or more than one-fifth of the total expenditure.

Some items of the publie debt are clearly reproduetive, stech as the capital invested in the railways, harbours. telegraphs, telephones, and land bank, and the loans male to local authorities. irrigation boards, and settlers on Crown land. Others, again. are essentially unproductive, the most important being expenditure on war and on those public works and buildings that do not yield revenue. Finally, there are items which appear to be reproductive at first sight but which prove to be partially unproductive. Loans to the Provinces and to edueational and industrial institutions can be classed as reproductive only to the extent to which the interest charges do not fall upon the Union taxpayer. Thus, loans to the Provinces are reproductive merely to the extent of one-half of their amount, since half the interest and redemption charges are met by the Union taxpayer through the annual subsidies paid by the Union Government.

The only practical method of arriving at any clear distinction between the productive and non-productive debt is to examine the incidence of interest charges and the proportion of interest which is earned by the various objects of eapital outlay, and the proportion which has to be met from taxation. By applying the proportions so ascertained to the public debt it is possible to determine how mueh of the debt may be regarded as paying for itself and how much falls as a dead weight on the revenue of the Union.

In ascertaining the interest charge on the unproductive debt, various factors have to be taken into consideration. In the first place, a fair proportion of the capital expenditure in respect of rail- 
ways and harbours has been paid out of revenue, either directly or indirectly by means of contributions towards the redemption of the loans from which the expenditure was made. Thus, on the 31st March, 1920. the interest bearing capital of the railways and harbours comprised $£ 92,125,471$ on the public debt account and $£ 13,138,263$ attributable to general revenue. Interest is paid by the Railway and Harbour Administration to the Consolidated Revenue Fund on the combined amounts; so that a corresponding deduction will have to be made from this interest in order to arrive at the amount of the interest on the public debt which is earned by the railways and harbours.

Secondly, with regard to the post office, including the telegraphs and telephones, no direct provision is made for the payment of interest on the capital investment; and furthermore the capital investment does not permit of accurate computation, as the capital expenditure in respect of the post office, and to a certain extent in respect of telegraphs and telephones, is ineluded under the head of "public works and buildings," in which ease a considerable proportion of the expenditure is defrayed from revenue, The gross receipts are paid into the Consolidated Revenue Fund and the operating expenditure paid out of that fund. However, there is almost invariably a small surplus, and for the purpose under consideration this surplus may be regarded as interest.

The proportion of interest on the public debt which is defrayed by taxation is comparatively small, generally less than one-third of the total interest charge, the greater part of the gross interest being earned by the various objects of capital outlay. The following table demonstrates that the taxpayers of the Union are not subjected to an overburdening interest charge, as is commonly held.

\begin{tabular}{|c|c|c|c|c|c|}
\hline Heading. & $\begin{array}{l}1911-12 . \\
\qquad\end{array}$ & $\begin{array}{c}1913-14 \\
f\end{array}$ & $\begin{array}{c}1915 \cdot 16 . \\
£\end{array}$ & $\begin{array}{l}1917-18 . \\
\quad \mathfrak{L}\end{array}$ & $\begin{array}{l}1919-20 . \\
f\end{array}$ \\
\hline Interest on Gross Debt . & $3,982,539$ & $4,233,598$ & $4,873,050$ & $5,813,866$ & $6,385,698$ \\
\hline $\begin{array}{l}\text { Interest on Railways and } \\
\text { Harbours Loan Capital, } \\
\text { on Government Loans, } \\
\text { etc., and Post Office }\end{array}$ & & & . & & \\
\hline Surplus & $2,800,000$ & $3,050,000$ & $3,300,000$ & $3,700,000$ & $3,900,000$ \\
\hline $\begin{array}{c}\text { Interest charged to unpro- } \\
\text { ductive debt } \ldots\end{array}$ & $1,182,539$ & $1,183.598$ & $1.573,050$ & $2,113,866$ & $2,485,698$ \\
\hline
\end{tabular}

The great increase in the interest on the unproductive debt was occasioned by the debt incurred in connection with the war. 
The foregoing table shows that out of a nominal interest eharge of $£ 5,813,866$ in $1917-18$ the taxpayers were required to contribute merely $£ 2,113,866$ or 36.3 per cent. This amount of interest payable out of revenue from taxation constituted 11.2 per cent. of the gross ordinary expenditure of the Union Government. Taking into consideration that at the time an expenditure of $£ 26,000,000$ had been incurred in respect of war operations, involving interest to the amount of slightly more than $£ 1,000,000$, the conclusion may justifiably be drawn that the Union is in a very favourable position as regards the incidence of its interest charges.

Applying to the total debt of the Union on March 31, 1920, namely $£ 173,905,000$, the proportions between the interest earned by the commercial undertakings of the Govermment and that charged to the unproductive debt for $1919-20, £ 3,900,000$ and $£ 2,485,698$ respectively, the following amounts are determined:

Productive and Unproductive Debt, 31 st March, 1920.

Heading.

Productive Deht

Unproductive Debt
P'roportion.

$\%$

61

39

100
Amount.

$\mathfrak{E}$

$106,082,000$

$67,823,000$

$173,905,000$

Total Debt

-

Thus, taking the incidence of the interest charge as the only practical basis for computation, it is found that in the beginning of 1920 , the public debt of the Union of South Afriea consisted of a reproduc-

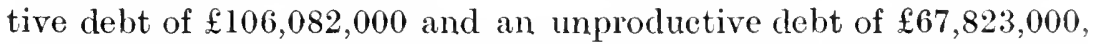
or 61 and 39 per cent. respcctively of the total debt. Prior to the War the proportion of reproductive debt was larger, as the War had occasioned a more than proportionate increase in the unproductive debt. For example, in 1911-12 the reproductive debt represented 70 per cent of the total debt.

Management of Public Debt.-The management of the public debt is vested in a board of Public Debt Commissioners, composed of the Minister of Finance as ex officio chairman, a member of the Railway Board, and one other member appointed by the Governor-General.' The powers and functions of these Commissioners are circumscribed in the Public Debt Commissioners Act of 1911.

Sinking fund contributions prescribed under any law enacted by the legislature of any Colony included in the Union are to be paid to the Commissioners and applied by them in accordance with the pro- 
visions of such laws." Redemption is provided for by various Colonial statutes, the annual redemption payments ont of revenue being generally in excess of $£ 600,000$. The most important of such redemption payments are those made in connection with the guaranteed loan of $£ 35,000,000$, granted by the British Government to the Transvaal and the Orange Free State in 1903 (the year after the elose of the Boer War) for the purpose of reconstruction, and the guaranteed loan of $£ 5,000,000$ by the British Government to the Transvaal in 1907, on both of which an annual redemption of 1 per cent. is due, comprising the sum of $£ 400,000$. In the Cape of Good Hope and Natal provision had likewise been made for contributions to the sinking fund in respect of eertain loans.

It is also provided that the surplus of revenue over ordinary expenditure in any year is to be paid to the Commissioners for loan redemption, and that the Commissioners are to be credited with such further sums as may lawfully become available from time to time for the redemption of debt."

Unless otherwise provided in any law, the Commissioners are to devote such moneys to the redemption or purchase of stock or debentures issued in respect of any loan, and thereafter all securities so redeemed or purchased together with the interest coupons (if any) applicable to such securities, are to be cancelled. If, however, it appears to the Commissioners to be in the public interest that the redemption of securities should be delayed until more favourable terms can be secured, they may effect a temporary investment of the moneys under their control; provided that they shall be restricted to the purchase of Treasury Bills and bonds of the United Kingdom or of any British Colonial Government which has eomplied with the provisions of the Colonial Stock Acts of the United Kingdom, or to deposits at interest with any banking institution of approved standing within the Union or in London.'

Sinking Fund.-During the decade under consideration the total receipts of the sinking fund amounted to $£ 11,595,556$, of which

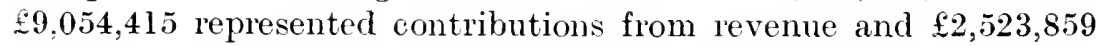
interest on investments, the remaining $\{17.282$ being composed mainly of profit on realization of investments. Of the contributions from revenue, surplus revenue accounted for $£ 3,157,612$.

On the other hand, payments to the extent of $\mathfrak{f} 6,279,782$ were made out of the fund, the sum of $£ 6,000,385$ having been applied to the cancellation of debentures and stock, and the remainder ot

\footnotetext{
5 Ibid, sec. 4.

(Act 18 of 1911 , secs. 5 and 6 .

7 Ibid, secs. 7 and 8 .
} 
meeting the loss on realization of investments, expenses of drawings, etc. Thus, the sinking fund was enhanced by $55,315.774$. from $\$ 4,540.422$ on Nay 31,1910 to $\$ 9,8.56 .196$ on Nareh 31,1920 , thereby reducing the gross national debt on the latter debt to $£ 164,049,000$.

The amount of $\$ 9.856,196$ in the sinking fund of the Union, on the

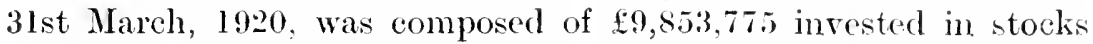
and the balance of $f 2,421$ in cash. The investments comprised

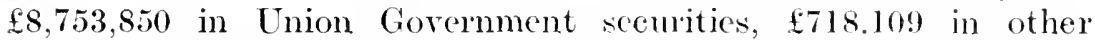

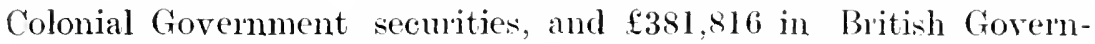
ment securities. The rate of interest in respect of these investments is on an average 4 per cent., ranging from $2 \frac{1}{2}$ per cent. in the case of certain India stock to 53 per cent. in the case of certain New Sonth Wales stock."

Method of raising Loans.-When authority is granted to raise any sum of money, the Government may, from time to time as it may deem expedient, raise such sum cither by stock issued in the Union (local stock) or by stock issued in the United Kingdom (consoli(lated stock), or by debentures issued in the Union or elsewhere. Local stock is to be disposed of either by public tender or by issue to the public at a fixed price, and the Treasury is to keep books relating to local stock and is to enter therein in respeet of each issice of stock:

(a) the name and address of each owner for the time being of any amount of stock;

(b) the amount of stock held by each owner and the date at which such stock was eredited to such owner.

On payment in full of the amount payable by an owner of stock in respect of the stock credited to him, the Treasury is to issue to him a certificate of the amount of stock standing to his credit. ${ }^{10}$

Debentures may be issued in the Union, or elsewhere, in sums of $£ 100$ or multiples thereof. Treasury bills may likewise be issued in sums of $£ 100$ or multiples thereof of a currency of twelve months or less, and any such bills may be renewed or 'xtended from time to time for a period not exceeding twelve months at any one time. With the concurrence of the holders, Treasury bills may, before the date thereof, be retired or converted into debentures or stock if it appears in the public interest to do so.

8 Quarterly Abstract of Union Statistics, Oct. 1920, . p. 78, and Auditor. General's Report for 1919-20, pp. 60-63.
9 Report of Public Debt Commis. sioners 1919-20, pl. 19-21.

10 Act 22 of 1917. secs. 4-6. 
The Government may appoint any bank or any person as agent for the issue, management or repayment of any securities.

The expenses necessarily incurred in connection with the issue of seeurities having a currency of not less than five years, including discount (if any), commission (if any), and all other expenses incidental to sueh issue are to be paid out of the amount raised, and the amount authorised to be borrowed is to be increased to that extent. All such expenses incurred in connection with the issue of securities having a currency of less than five years are to be paid out of the revenue account.

The Government may, on maturity, repay any securities and it may raise the money required for such repayment by the issue of new securities, and such issue is deemed to be within the borrowing power authorised by Parliament." The Government was also empowered to eonvert, renew or consolidate the colonial debts.

Funded and Unfunded Debt.-.The following table' ${ }^{12}$ shows the relation between the funded and the unfunded debt at the date of Union (May, 1910) and on the 3lst March, 1920.

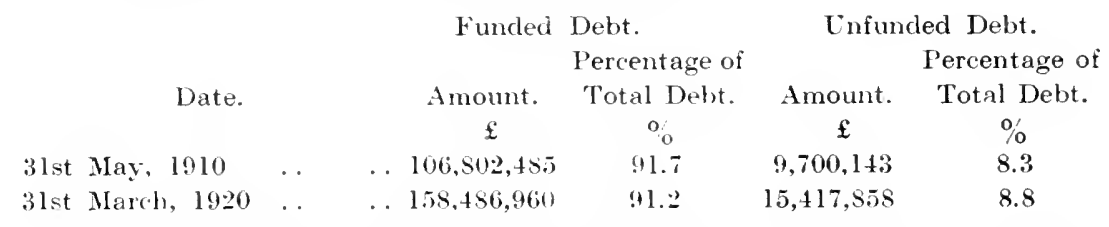

On the 3lst Mareh. 1920, the funded debt of the Cnion consisted of $£ 144,7+6,760$ in stock and $£ 13,740,200$ in debentures, and the average rate of interest on the funded debt was 3.77 per cent. in 1920 , as compared with 3.37 per cent. in 1910 . The unfunded debt eomprised $£ 6,425,300$ in Union Treasury Bills, $£ 1,606,343$ in Union Loan Certificates, and $£ 7,386,215$ in respect of advances from the Imperial Government during the $\mathrm{War}$, the average rate of interest being 4.4 per cent. ${ }^{13}$

Foreign and Domestic Debt.- The following table ${ }^{1 *}$ shows the marked ehange in the relation between the foreign and the domestic debt during the decade from 1910 to 1920 .

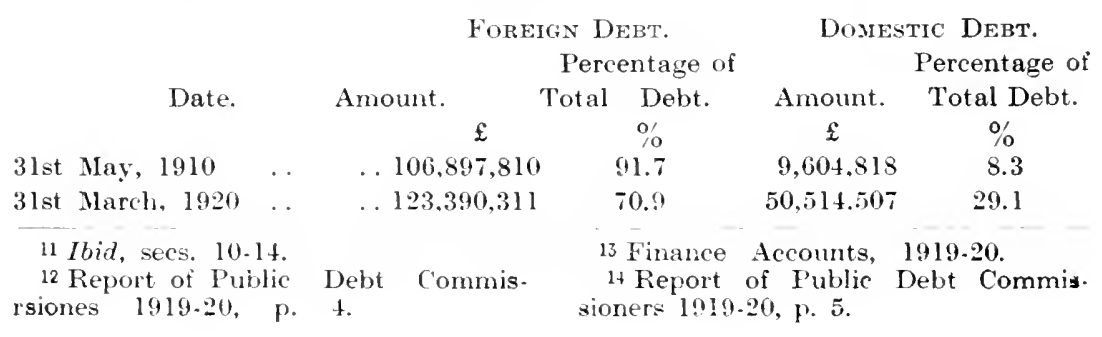


Prior to 1915 the government loans were generally secured from abroad. At that time the Union Government was in great need of funds for financing its military operations and could not resort to the London money market in view of the demands of British war finance. Accordingly, an appeal was made to the South African public, to which there was an adequate response.

Comparison with other Countries.-It is practically impossible to make accurate comparisons between the per capita public indebtedness in the Union of South Africa and that in other countries. on account of the important differences in respect of population, constitution, and scope of governmental functions.

In the first place, the numerical preponderance of the coloured races in the Union and the difficulty of determining the relative economic position of the individual of the coloured races and the individual of the white race constitute serious obstacles to the establishment of a comparable basis. In 1920 the total population of the Union was estimated to be $7,305,377$, namely $1,503,904$ white and $5,801,473$ coloured, or 20.6 and 79.4 per cent. respectively. If the economic relation of the white to the coloured is taken to be 1 to 4 for the purpose of comparison with other countries, the economic population will be about 3 million. Thus the per capita debt of the Union may be regarded as $\mathfrak{f} 64$ on the 3 lst March, 1922 .

Secondly, under the system of unitary government prevailing in South Africa the responsibility for the whole of the public debt (excluding local debt) is vested in the Union Government, whereas in countries with federal constitutions, such as the Cnited States of Anerica, Australia. Canada, Germany and Switzerland, each state or province has its own debt. For example, the public debt (exclusive of local debt) of the United States consists of the Federal debt plus the debts of the 48 states. Our provincial debt is a constituent part of the Union debt.

Thirdly, the scope of governmental functions in the Union of South Africa is considerably more extensive than in most other countries, inasmuch as the Union Government undertakes the development of railways, harbours, telegraphs, telephones, irrigation, land settlement, forestry, etc. The greater part of the Union debt is essentially reproductive, viz.. more than 60 per cent., whereas nearly the entire American debt is umproductive and by far the largest portion of the English or French debt.

Accordingly, in making a comparison between the per capita debt in the Union of South Africa and that in the United States of America, the white population of the Enion must first be doubled 
(riz. 3 million); then the debts of the American states must be added to the federal debt; and finally the unproductive debt only must be taken, namely $£ 70$ million for the Union in 1922 or $£ 23$ per capita. The total American debt was in 1920 over 4,000 million pounds (after deducting $\$ 950$ million due by the British Government and also the reproductive debt), or $£ 40$ per capita. It must, however, be taken into consideration that the per eapita national income is much larger in America than in South Africa, and that therefore our unproductive debt of $f 23$ per capita is perhaps a heavier burden than the American debt of $f 40$ per capita.

The countries whose conditions most nearly approximate those in South Africa and which therefore afford the most appropriate basis of comparison are Australia and New \%ealand, where the

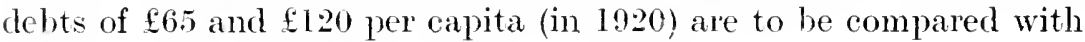
our gross debt of $\mathfrak{f} 64$ per capita (in 1922).

In 1920 the public debt of England was $£ 160$ per capita, of France $£ 1, n$. Germany $£ 1 \geq 0$, Austria $£ 110$, Italy $£ 80$, Russia $£ 60$, Belgium $\$ 0$, Canada $f 40$, ete. These high figures are due to the tremendous war debts of those countries and should not render us liable to the impression that our debt is comparatively small and that therefore we need not regard the matter scriously. 


\title{
PART IV.
}

\section{ADMINISTRATION AND CONTROL OF THE FINANCES.}

\author{
CHAPTER 1 \\ The Financial Relations Betiveen the Uxion and \\ the Provinces.
}

The Union Constitution does not contain a rigid definition of the financial relations between the Union and Provincial Governments, as in the case of the federal constitutions of the United States, Canada, or Anstralia, but provision was made for an elastic system of finance by assigning the final determination of those relations to the Union Parliament, which is to effect such re-adjustments as altered conditions and cireumstances may demand.

Under the Union Constitution the powers of the Provincial Commeils were confined to the following activities: ${ }^{1}$

(I) education. other than higher education;

(2) the establishment, maintenanee, and management of hospitals and eharitable institutions:

(3) local works and unclertakings within the provinee, other than railways and harbours and other than such works as extend beyond the borders of the province:

(4) roads, ponts, and bridges, other than bridges connecting two provinces ;

(5) agriculture to the extent and subject to the conditions to be defined by Parliament;

(6) preservation of fish and game;

(7) direct taxation within the province in order to raise a revenue for provincial purposes.

Instead of defining the fiscal jurisdiction of the Provinces, the Union Constitution directed the Union Government to appoint a commission of inquiry into the financial relations which should exist between the Union and the Provinces. This eommission was to consist of one representative from each province and was to be presided 
over by an officer from the Imperial Service. Pending the completion of the inquiry and until Parliament otherwise provided, the Union Government was to pay annually out of the Consolidated Revenue Fund to the administrator of each province ;

(a) an amount equal to the sum provicled in the estimates for education, other than higher education, in respect of the financial year 1908-1909, as voted by the Legislature of the corresponding colony during the year 1908 ;

(b) such further sums as the Government may consider necessary for the due performance of the services and duties assigned to the provinces respectively.

Until such inquiry was completed and Parliament made other provisions, the executive committees in the several provinces were required to submit annually estimates of their expenditure for the approval of the Union Government, and no expenditure was to be incurred by any executive committee which was not provided for in the approved estimates. ${ }^{2}$

The majority report of the Financial Relations Commission served as the basis of the Financial Relations Act, which came into operation on April 1, 1913. Thus, from the date of the constitution of the Union (May 31, 1910) until April 1, 1913, all the funds required by the provinees were provided by means of grants from the Union Treasury. In accordance with the Financial Relations Act, the funds required by a province to meet its normal or recurrent expenditure upon matters entrusted to it are derived from the following sources :"

(a) moneys appropriated by the Union Parliament by way of subsidy to the province;

(b) the sources of revenue transferred and the revenues assigned to the province under the act;

(c) such other revenues as may be raiser by the province under the authority of law, i.e. by virtue of its taxing powers under the constitution.

Under the Financial Relations Act of 1913 the amount of the subsidy was to be one-half of the normal or recurrent expenditure, provided that, if in any provinee the normal expenditure for any financial year exceeded that of the previous financial year by more than $7 \frac{1}{2}$ per cent., that provinee was entitled by way of subsidy in the succeeding year to one-third only, in lieu of one-half, of that excess.' In 1917 an amendment was made to the effect that, if

2 S.A. Act, sec. 118.

3 Act 10 of 1913 , sec. 4 .

4 Act 10 of 1913 , sec. 5 . 
the nomal expenditure for any year exceeded that of the previous year by more than 15 per cent. in the case of primary and secondary education and 5 per cent. in respect of any other matter, that province was entitled to one-third only of that excess; $;$ and in 1921 it was limited to 5 per cent. in respeet of the expenditure on education, no increase in subsidy being permitted in respect of other expenditures. In 1922 it was enacted that the subsidy for the year 1922-23 was to be only nine-tenths of the amount paid over to the respective provinces in 1921-22, and that in respeet of any financial year after 31 March, 1923, the subsidy was not to be increased by more than 3 per eent. over the amount paid in the preceding year.

In the case of Natal and the Orange Free State a special subsidy of $£ 100,000$ per annum was granted, in view of the fact that the funds otherwise placed at their disposal were insuffieient to balance the commeneing expenditure of these provinces.

It was specially provided that the expenditure of any divisional council, school board, or native council out of revenues raised locally should rank as ordinary expenditure of the province for the purpose of assessing the subsidy." This provision was necessary in order to put the Cape Province on terms of equality, financially, with the other provinces, as the provincial services in the Cape are, to a great extent, undertaken and paid for by subsidiary local authorities; so that the charges on the Cape Provincial Revenue Fund and consequently the subsidy payable by the Union Government in respect of these charges are relatively less than in the other provinces, where no such system of devolution exists.

As the trading and liquor licence revenues in Natal are collected by the Municipalities, provision was made for a special grant to that province equal to the revenue ascertained by the Treasury to have been derived by the municipal or local authorities in Natal from trading licences (other than those to earry on trades which are subject to municipal supervision and inspection) and from licences for the sale or supply of intoxicating liquor. ${ }^{i}$

As a result of these special grants and speeial provisions for the assessment of the subsidy payable to the Cape Province, the Union Government subsidy represents on an average about 62 per cent. of the total ordinary revenue of the four provinces taken as a whole, as indicated in the following statement :

5 Act 9 of 1917 , Schedule. Act 10 of 1913 , sec. 14 .

t Act 10 of 1913, sec. 5 . 
Provincial Revenue.

Revenue Collected by the Provinces
Union Government Subsidy

Total Revenue of the Provinces..

\begin{tabular}{|c|}
\hline $\begin{array}{c}1913-14 . \\
£\end{array}$ \\
\hline $1.289,190)$ \\
\hline $2,165,100$ \\
\hline 454.290 \\
\hline
\end{tabular}

$1915 \cdot 16$.

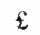

$1,134.566$

$2,0+9,627$

$3,184,193$

$1916 \cdot 17$.

$\mathfrak{f}$

$1,423,667$

$2,345,517$

$3,769,184$

The following table shows the distribution of the Union Government subsidy between the provinces and the relation thereof to the ordinary expenditure of the several provinees, for the financial year 1916-17:

\begin{tabular}{|c|c|c|c|c|c|}
\hline \multirow[t]{2}{*}{ Province. } & & & $\begin{array}{l}\text { Union } \\
\text { Government }\end{array}$ & $\begin{array}{c}\text { Ordinary } \\
\text { Expenditure. }\end{array}$ & $\begin{array}{l}\text { Percentage } \\
\text { Pelation of } \\
\text { Subsidy to } \\
\text { Expenditure }\end{array}$ \\
\hline & & & $£$ & $\mathfrak{£}$ & $\%$ \\
\hline Cape of Ciood Hope & . & . & 935,161 & $1,286,038$ & 72.7 \\
\hline Transvaal & . & . & 710,999 & $1,425,584$ & 49.9 \\
\hline Orange Free State... & . & . & $345,0 \geq 9$ & 519,973 & 66.3 \\
\hline atal.. & $\ldots$ & $\therefore$ & 354,328 & 477,089 & 74.2 \\
\hline
\end{tabular}

In the case of the Cape of Cood Hope, the high percentage is attributable to the provision that the expenditures by divisional councils, school boards, or native councils out of revenues raised locally are to be regarded as part of the normal expenditure of the provinees for the purpose of assessing the subsidy. In the Orange Free State and Natal the high percentages are due to the special subsidy of $£ 100,000$ per annum and, also, in the case of Natal, to the special grant by the Union Government in lien of the revenue from trading and liquor licences which accrues to the municipalities in that province. In the case of the Transvaal the percentage is slightly under the provision of one-half of the normal or recurrent expenditure in view of the proviso that, when the expenditure increased by more than $7 \frac{1}{2}$ per cent. over that of the previous financial year, the province was entitled to one-third only of that excess.

For the purpose of detérmining the amounts to be appropriated in any financial year in respect of subsidies to the provinces, the Administrator of each province is to transmit to the Treasury on such date as it may from time to time direct, a eertificate of the amount which is estimated by the executive committee of the provinces to be required for meeting the normal expenditure thereof during such finaneial year. The subsidies, when appropriated, are to be wholly paid over to the respective provinces during the finaneial year to which they are applicable, provided that, if by reason 
of an over-estimate or under-estimate of the requirements of any province the payment in respect of subsidy is shown to have been in excess of, or less than, the subsidy whieh that province is entitled to receive in respect of that year, the necessary adjustment is to be effected by abatement from or addition to (as the case may be) the payment which that province is entitled to obtain in the succeeding year."

The normal or recurrent expenditure of a province is defined as comprising :

(a) the cost of general administration in the province:

(b) the cost of carrying out the matter's cntrusted to the province, where such cost is not to be treated as capital or nonrecurrent expenditure :

(c) the interest and sinking fund payments for which the provinee is liable in respect of advances made to it by the Union Treasury to meet capital expenditures :

(d) the cost of construction and maintenance of roads, provided that, in speeial cases authorised by the Treasury, the cost of construction of any particular road. but not of its maintenance, may be regarded as capital or non-recurrent expenditure!"

Sources of Revenue Transferred to Provinces.-The Financial Relations Act of 1913 transferred the following sources of revenue to the provinces:

(a) hospital fees, and fees received in respect of education other than higher education:

(b) the duty payable uncler any law upon the takings of any instrument, machine, or contrivance used in connection with betting on races (commonly known as a totalisator) by the licensee thereof;

(c) auction dues:

(d) licences required for dogs outside urban areas; lieences to take, catch or kill game, fish or other animals : licences to pick or sell wild flowers;

(e) all other payments for trading or professional licences, save such as are retained by the Union Govcrnment;

$(f)$ miscellaneous receipts connected with matters entruster to a province. $^{10}$

8 Act 10 of 1913 , sec. 7 .

9 Act 10 of 1913 , sec. $6(2)$.

10 lbid, sec 11 and First siheduls. 
These sources of revenue were transferred to the provinces, together with the power to legislate in respect thereof.

Revenues Assigned to Provinces.-The following revenues were assigned to the provinces, but the power to legislate in regard thereto was retained by the Union Parliament :

(1) transfer duty on fixed property :

(2) licences for the sale or supply of intoxicating liquor;

(3) native pass fees payable in the labour districts of the Transvaal.

These revenues are raised and received by the Union Government, but, instead of being paid into the Consolidated Revenue Fund, the proceeds are paid over by the Union Treasury (without deduction for the cost of collection) to the province from which such proceeds have bren raised or received."

Dired Taxation in the Provinces.-Under the Enion Constitution authority is conferred upon the Provincial Councils to levy direct taxation within the Province in order to raise revenue for provincial purposes. The principal forms of direct taxation which have thus far been resorted to by the provinces are : a tax on the payments for admission to entertainments ; a duty on the receipts from totalisators on racecourses ; a wheel tax ; a house tax (in the Transvaal) ; a tax on bachelors, converted into a poll tax in 1921 (in the Transvaal); a tax upon immovable property (in the Cape of Good Hope) ; a tax on admission fees charged by owners of racecourses; a tax on bookmakers, etc.

Capital Expenditure in the Provinces.-The funds which may from time to time be required by any province for the purpose of meeting any capital or non-recurrent expenditure are advanced to that province by the Union Treasury upon loan in such amounts as Parliament may authorize by annual appropriation. Any such advance bears interest at a rate not exceeding 5 per cent. per annum from the date of issue, and is to be repaid by the Province to the Treasury in equal half-yearly instalments so calculated that the whole advance and the interest thereon will be paid within a period of not less than 15 years ${ }^{12}$ and not exceeding 40 rears, regard being had to the nature of the work for which such advance is made.

Specific provision is made, in the Financial Relations Act, that the interest and redemption charges are to be treated in the Appropriation Ordinance and in the accounts of the province as part 
of its normal or lecurrent expenditure, for the purpose of atsessing the Union subsidy. ${ }^{13}$ Thus loans to provinces are only reproductive to the extent of one-half of their amount, since the Union Treasury pays one-half of the interest and amortization charges through the annual subsidies.

Capital or non-recurrent expenditure. in the case of the Provinces, is defined as comprising expenditure (whether directly or by loan to local bodies) upon the erection. construction, acquisition. extension, or improvement of any building, bridge, or pont, or upon any work of a permanent nature in relation to a matter entruster to the province, but not expenditure upon the construction of a road unless authorised by the Treasury; provided that if the expenditure npon any such building or extension thereof does not exceed $£ 1,000$, or if the expenditure upon any bridge, pont, or other such work does

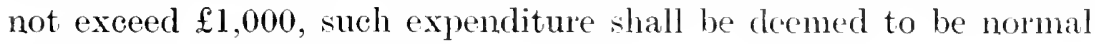
or recurrent expenditure. ${ }^{11}$

The most striking feature in respect of the financial relations between the Union and the Provinces is the almost entire dependence of the Provinces upon the Union Government with regard to financial affairs. In the first place, the Provinces are dependent on subrentions from the Union Govermment in order to defray their comparatively limited expenditure. Secondly, the Provincial Councils have certain powers of taxation, but these, like all other matters of legislation, are subject to the reto of the Union Gorernment. Thirdly, the Provinces are not permitted to borrow from any source other than the Union Treasury, except that a Province may borrow from a bank by way of temporary overdraft for a period not exceeding 6 months, such sum as may be required to meet a deficit in the provincial revenue fund. ${ }^{15}$ 


\section{System of Financial Administration.}

\section{Union Finance.}

Department of Finance.-The Department of Finance is placed under the control of the Minister of Finance, who is responsible to Parliament. The Secretary for Finance is the permanent head of the Department, the administrative functions of which permit of the following subdivision:

(1) the Treasury proper :

(2) the Department of Inland Revenue;

(3) the Department of Customs and Excise ;

(4) the Public Debt Commissioners.

Treasury.-The general control of the finances of the Union (excepting the finances of the Railway and Harbour Administration) is vested in the Treasury. It is charged with the performance of all duties relating to appropriation and supply (except for the services of the Railways and Harbours), with the regulation of the financial relaticas between the Cnion Government and the Provincial Administrations, the raising and management of loans, the payment of pensions and gratuities, the supervision of banking institutions and the regulation of the currency.

The Treasury is divided into the following branches :

(a) Accounts Section, which is under the control of an officer designated the Chief Accountant, ranking in status next to the Under Secretary, and deals with all matters relating to the system of accounts ;

(b) Establishments Section, which is supervised by an offlcer with the rank of Chief Clerk and deais with all matters relating to the establishment of the Public service, namely, the creation of posts, the fixing of emoluments, etc. ;

(c) Pensions Section, which is also controlled by an officer with the rank of Chief Clerk and is responsible for the administration of all pension laws.

Department of Inland Revenue.-The Department of Inland Revenue is concerncd with the imposition, assessment, and collect- 
ion of revenues other than eustoms and excise and postal revenue. The Department is under the eontrol of an officer designated the Commissioner for Inland Revenue.

The eolleetion of revenue in the larger towns is undertaken by officials paid by, and directly responsible to, the Department of Inland Revenue. There are 13 departmental revenue officers in the Union. In the remaining towns and districts at which there are revenue offices (numbering in the aggregate 2.27 ) the magistrate is the local receiver and, as such, reports directly to the Department of Inland Revenue concerning revenue matters.

The multifarious duties imposed upon the magistrate, as the ehief Government representative in the distriet, result in the ineffieient performanee of revenue work. This is not the fault of the magistrate whose work is conseientiously performed under great difficulties, but of the system. With the exception of the magistrates in the Transkeian Territories, who are responsible to the Native Affairs Department, the magistrates are on the establishment of the Department of Justice, and it is natural that they should regard the work of that department as of paramount importanee and the work of the Revenue Department as of secondary concern only.

The ideal solution, ${ }^{1}$ in the opinion of the Commissioner for Inland Revenue, is a separate revenue establishment, under which the Union would be divided into large collecting areas supervised by a senior offieer, with wide diseretionary powers, and with eollecting offieers in the important places within the area. The head office would then confine itself to initiating the procedure necessary for the colleetion of taxes levied, the general supervision and control of the collecting areas, and the consolidation of the collections made. and would be the final reference authority for the solution of questions of real difficulty or disagreement between the public and the eollecting officers.

The conditions created by the war rendered it almost impossible to effect any important changes, although in 1918 an attempt was made to simplify and co-ordinate the accounting system in the offices of all receivers of revenue. This work is now on a uniform basis throughout the Union.

The Department of Customs and Excise.-The Department of Customs and Exeise is under the control of the Commissioner of Customs and Excise and is eharged with the administration of the laws relating to Customs and Excise and the colleetion of dues thereunder.

\footnotetext{
1 Report of Commissioner for:Inland Revenue, 1916-17, pp. 3.4.
} 
Upon the constitution of the first Ministry of the Union a portfolio of Conmerce and Industries was created which provided for the control of customs and excise. as also of industrial and commercial matters. Subsequently, however, the Department of (Commerce and Industries was abolished, and ministerial control of customs and excise was vested in the Department of Finance.

Public Debt Commissioners.-The investment of all trust funds, e.g. Ninking Fund, Pension Fund, Guardian Fund. and Post Office Savings Bank moneys, coming into the hands of the Government or the Railways and Harbour Administration, and the management of the public debt are vested in a board of Public Debt Commissioners, composed of the Minister of Finance as ex officio chairman, a member of the Railway Board, and one other member appointed by the Governor-(ieneral."

A bank account is to be kept in the name of the Commissioners, into which are to be paid all the moneys to be dealt with by the Commissioners and from which are to be withdrawn the moneys required to meet the payments for which they are responsible. ${ }^{3}$

sinking fund contributions prescribed under any law enacted by the legislature of any Colony included in the Lnion are to be paid to the Commissioners and applied by them in accordance with the provisions of such laws. It is also provided that the surplus of revenue over ordinary expenditure in any year is to be paid to the Commissioners for loan redemption, and that the Commissioners are to be credited with such further sums as may lawfully become arailable from time to time for the redemption of debt.

The Public Debt Commissioners are also entrusted with the investment of deposits, subject to the retention at the disposal of the officers who have the Control, management or administration of any deposits of such reasonable working balanees as may be approved by the Minister of Finance. The Commissioners are empowered to sell or otherwise dispose of securities held by them as investments whenever they may think it advisable to do so in the public interest. ${ }^{5}$

The accounts of the financial transactions of the Commissioners are to be kept in the Treasury. As soon as possible after the close of each financial year the Treasury is to prepare and transmit to the Controller and Auditor-General accounts showing the amounts due by the Commissioners in respect of each sinking fund and of each class of deposits controlled by the Commissioners, and showing also

\footnotetext{
2 Act 18 of 1911 , sec. 2 .

3 Ibid, sec. 3 .

4 Act 18 of 1911 , secs. 4,5 , and 6 .
5 Ibid, secs. 9 and 12 .
} 
the investments held by them in respect thereof. Any profit earner! by the Commissioners in connection with their transictions in any financial year is to be payable to the Consolidated Revenue Fund, and any loss incurred by them is to be chargeable to that fund."

Consolidated Revenue Fund.-In accordance with the provisions of the Union Constitution, a Consolidated Revenne Fund was instituted, into which are paid all revenues raised or received by the Union Government other than the revenues from the administration of the railways, ports, and harbours, which are paid into a fund designated the Railways and Harbours Fund.'

The Consolidated Revenue Fund comprises the Revenue Account and the Loan Account, the former being credited with all money, received from revenue proper, the latter with moneys derived from the raising of loans, together with the following receipts:

(a) moneys received in respect of the sale of Crown Lands;

(b) moneys received in respect of the proceeds of the realization of assets originally purchased from the loan account ;

(c) moneys received in respect of the repayment of advances or loans made from the loan account;

(d) moneys accruing to the Crown under any lease or other contract disposing of a right to mine for precious or base metals, to the extent to which such moneys exceed the amount payable in respect of any claim licence or taxation which would have been paid to the Crown if the right leased or disposed of or the profits derived from the mining had been by law subject to the payment of such licence money or taxation ;

(e) such sums as by vote of Parliament may be direeted to be so placed."

Exchequer Account.-Provision has been made for a bank account entitled "The Account of the Exchequer of the Union of South Africa," into which are paid all sums payable to the Consolictated Revenue Fund and all sums lawfully borrowed.

Receipt and Custody of Revenues.-All revenues are to be accounted for by principal receivers of revenue, and for this purpose revenues are classified under four main divisions:

(a) revenue from Customs and Excise, to be accounted for by the Commissioner of Customs and Excise;

(b) revenue from Posts, Telegraphs, and Telephones, to be accounted for by the Postmaster-General ;

$6 \mathrm{Ibid}$, sec. 13.

7 S.A. Act, sec. 117
8 Aet 22 of 1917 , sec. 3 .

9 Act 21 of 1911. sac. 22 (1). 
(c) Inland Revenue, to be accounted for by the Commissioner for Inland Revenue;

(d) proceeds of loans raised and other loan revenues, to be accounted for by the Secrctary for Finance. ${ }^{10}$

The Commissioner for Customs and Excise and the Commissioner for Inland Revenue are to credit all revenues and other moneys collected by their departments to a bank account entitled the "Customs and Excise Account" and the "Inland Revenue Account" respectively. At the end of each business day they are to transfer from those accounts to the Exchequer Account the amounts banked duing the day, after deduction of the payments for drawbacks, repayments, or discounts which the departments under their control nray be subject to.

The Postmaster-General is to pay all revenues and other public moneys collected by his department and all deposits made with him to the credit of an account to be kept at the bank entitled the "Postmaster-General's Account." The growing balances of this account are available for meeting the drawbacks, repayments, and discounts to which the postal receipts may be liable, and in addition for meeting temporarily the current liabilities of the department, provided that the amount of all disbursements made from the account to meet the cost of administration of the department is to be repaid as soon as possible out of the moneys provided by Parliament for such services; and the Postmaster-General is to make transfers out of the growing balances on the "Postmaster-General's Account " to the credit of the Exchequer Account.

The proceeds of all loans raised are to be lodged in the Exchequer Account provided that in the case of loans raised in the United Kingdom the proceeds thereof are to be paid by the High Commissioner to his official account at the bank in London, and the amount thereof is to be entered into the Exchequer Account in the Treasury books upon the receipt by the Treasury of adrice from the High Commissioner.

Recoveries of advances are to be paid to the credit of the account (revenue or loan, as the case may be) from which the advances were made. ${ }^{11}$

Collection of Revenues.-The responsibility for the collection, custody, banking, and management of revenues is vested in the principal receivers thereof. Principal receivers of revenue are personally responsible for the prompt and effective collection of all

io Financial Regulations, p. 8.

11 Financial Regulations, p. 8. 
revenues placed under their control, and for duly accounting therefor. No irrecoverable revenue is to be written off without Treasury Authority, but in special circumstances, where such a course may scem to be in the interests of the public service, the Treasury may delegate to principal receivers and accounting officers, authority to write off revenues under their control that may be found to be irrecoverable.

The accounts of principal receivers of revenue are to show the gross amount of revenues collected, the sums paid out by way of refunds, and the net amount due to the Exchequer Account.

Revenues and other public moneys are payable in cash, in the following forms:

(a) Bankers' drafts.

(b) Cheques marked by a banker.

(c) Post Office money orders.

(d) Postal order's.

Returns of Revenue.-The Commissioner of Customs and Excise, the Commissioner for Inland Revenue, and the Postmastrr-General are each to render to the Controller and Auditor-General at the end of every month an account showing :

(1) the general heads and each sub-head of revenue collected ;

(2) all non-revenue receipts, classified according to their individual accounts :-

(a) the gross receipts during the month;

(b) the refunds for drawbacks, repayments, or discounts ;

(c) the net receipts;

(d) the total net receipts from the commencement of the financial year.

As soon as possible after the elose of the financial year, these three principal receivers of revenue are to furnish statements showing :

(1) for that financial year, under each head and sub-head of revenue appearing in the estimates, the gross amount collected in his department, the disbursements in drawbacks, repayments, and discounts, and the net amount due to the Exchequer ;

(2) a comparison between the astual and the estimated revenue. and between the revenues of the two last completed financial years under each head, together with explanations of the increases and decreases;

(3) the amount of revenue outstanding at the close of the financial year under each head; 
(4) the amount- written off as irrecoverable during the financial year.

All feen received hy officers in their official capacities are to be paid into the revenue aceont, unless such fees are assigned by proper anthority as personal remuneration. A note of the fees so assigned as personal lemuncration is to appear in the estimates."

Administration of Expenditures.-Acconnting Officers are responsible for the general financial administration of the rotes or funds in their charge. The accountant or clerk in cluarge of accounts of each department is responible to the accounting officer for keeping the various aecounts. For the aceuracy of those accounts, and for the safe eustody of the public money entrusted to him. He is to prepare requisitions upon the Treasury for fund necessary to meet expenditure chargeable to the varioms votes of his department, and to prepare cliafts for payment.

Issues to sub-accountants are to be made by accounting officers by draft. and such issues are to be regarded as being of the nature of advanees to be aecounted for monthy to the aecounting offieer, and are not to be treated as final charges until they have been accounted for and vouchers furni-hed in support of the expenditure.

The official banking accounts of accounting officers are to be with the Paymater-General. In any case where it is deemerl to be esiential that an officer should be allowefl to open an official account with any bank the written authority of the Treasury must first be obtained, and the requisite instructions shall be issued to the bank by the Treasury.

Aecounting officer's are provided with such banking accounts with the Paymaster-General as the Treasury may deem neeessary, such as (a) "Vote" accounts. to which are to be eredited all moneys received relating to voted services and on which are to be drawn all warrant rouchers in respect of parments for roted services, and (b) "Deposit" aceount. to which are to be paid all revenues and other moneys received by accounting officers which have no relation to roted services and from which are to be paid all clisbursements in respect of such moners.?

Inter-departmental Serices.-Any department requiring a service which another department is specially charged to perform is to requisition on that department for the performance of the service, but the Treasury may anthorise a deviation from this regulation in special eases where it can be hown that the service can be otherwise

12 Financial Regulations, pp. 10 \& 11 . 13 Lbil, pp. 12, 13 and 23. 
more economically performed. All department: are to obtain all stationery and printing required by them from the Printing and Stationery Department, and all furniture, cleaning materiak. ete., from the Public Works Department. If, in cases of urgeney, sueh articles have to be purchased dircet, the areounts are to be submitted to either of those departments, or, if already paid, the cost is to be recovered from the appropriate votes of those departments upon the paid vouchers. ${ }^{1+}$

\section{(2) Railway and Harbour Finance.}

The Enion Constitution provided for the institution of a Railway and Harbour Fund, into which are to be paid all revenues raised or received by the Union Government from the administration of the Railways, Ports, and Harbours.."

The Railway and Harbour Fund comprises a Revenue Account and a Capital Account. Capital expenditure is mainly finaneed from Loan Fund Moneys, that is to say, moneys obtained by the flotation of loans in the open market by the Union Government. These loans have as security to the investors the entire assets of the Union, and the proceeds of the amounts realized are retained by the Treasury. The Railway and Harbour Administration obtains what it requires in regard to capital expenditure from the Treasury in such sums and at such times as are considered to be most economical, and it has no liability in respect of the cost of raising loans or discount expenses in connection with the flotation of loans. Such expenses are wholly defrayed by the Treasury, jointly with expenses for meeting the requirements for public works and other purposes served by loans."

The railways and harbours constitute an independent service of the Union Government, their finances being administered entirely separate from those of other government departments. The railway and harbour budget is prepared and presented to Parliament by the Minister of Railways and Harbours, and. unlike other Departments of State, the Department of Railways and Harbours does not come under the control of the Minister of Finance. It is only when the Railways and Harbours Administration requires additional loan funds for railway construction and other eapital works that the Minister of Finance is consulted, as he has to provide the necessary funds from the Loan Account.

\footnotetext{
14 Financial Regulation, pp. 21 \&2. 15 O.Y.B. 1919. p. 795.

15 S.A. Act, sec. 117.
} 
(3) Provincial Finance.

In respect of provincial revenues, provision was made in the Union Constitution for a Provincial Revenue Fund in every province, into which are to be paid all revenues raised by or accruing to the Provincial Council and a!l moneys paid over by the Union Government to the Provincial Council, ${ }^{17}$ such as the subsidies, the revenues assigned by Parliament to the Province, and the advances from the Union Treasury in respect of the capital expenditure of the Province.

Funds for the capital or non-recurrent expenditure of the Provinces are advanced by the Union Treasury, acting under the sanction of Parliament, at a rate of interest not exceeding five per cent. per annum, being repayable in half yearly instalments extending over a period of not less than 15 nor more than 40 years. The provincial debt is thus a part of the Union debt, the provincial loans being included in the investment account of the Union Govermment. 
CHAP'TER 3.

\section{Budgetary Procedure.}

(1) Union Budget.

The budget statement in respect of the finances of the Union (excluding Railways and Harbours) is delivered by the Minister of Finance in the Legislative Assembly towards the end of the financial year, namely, in March of each year, and is introduced by way of a motion "that the House go into Committee of Supply upon the estimates of expenditure for the financial year...." The main purpose of the Budget Statement is to inform Parliament of the financial position of the country for the year about to close and of the estimated position for the ensuing year based upon figures which are furnished by the principal receivers of revenue and accounting officers.

In the preparation of the Budget the following officials are concerned :

$$
\begin{aligned}
& \text { Minister of Finance. } \\
& \text { Secretary for Finance. }
\end{aligned}
$$

Principal Receivers of Revenue.

(1) Commissioner of Customs and Excise.

(2) Commissioner for Inland Revenue.

(3) Postmaster-General.
Accounting OfFicers for ExpendiTURE. VOTES.

The principal receivers of revenue are the permanent heads of the three revenue-collecting departments. The accounting officers for the expenditure votes are not neeessarily the permanent heads of the various departments, but, generally speaking, these officer's undertake the responsibility for their votes. In fact, there are only two cases where officials other than the head of the department concerned fulfil the obligations of accounting officer', namely, the Under Secretary in the ease of the Treasury and the Chief Inspector in the case of the Control and Audit Office.

The estimates of revenue for each financial year are to be submitted to the Treasury by the principal receivers of revenue, who are to show under the various heads:

(a) the anticipated revenue for the ensuing financial year ;

(b) the estimates of revenue for the expiring financial year ; 
(c) a foreeast of the revenues that will be received during the expiring financial year ;

(d) the actual reeeipts for the preceding financial year. ${ }^{1}$

The draft estimates of expenditure, ineluding expenditure upon loan services, are to be prepared by the accounting officer of each vote, who is responsible for furnishing all the information necessary in connection therewith. The following data are to be inserted against each salary item under the sub-head "Salaries, Wages, and Allowances":

(a) the number of officers for whom provision has been made ;

(b) the number of offieers provided for on the estimates of the expiring financial vear ;

(c) the description and amount of any allowances other than local or elimatic allowances drawn by, and of any free services granted to. any officer of the administrative and elerical service.

The approval of the Treasury is required for the inclusion in the draft estimates of :

(a) any addition to the number of officers (permanent or temporary) provided for in the estimates for the expiring year ;

(b) any increase in the salaries of existing officers other than the ordinary inerements attaehed to their seales or authorised rates of remuneration:

(c) any new work or service and any increase in the authorised provision for any existing work or service.

All programmes of new works for which provision has to be made, whether upon revenue or loan votes, are to be submitted in advance of the estimates by aeeounting offieers to the Ministerial Head of the Department, who is to refer them to the Treasury, and the Treasury again, after examination, is to submit them for the instruetions of Ministers.

The draft estimates of expenditure for cach department within a ministerial division are to be submitted to the Treasury by the permanent heads of ministerial divisions, and the final estimates are to be presented to Parliament by che Minister of Finance."

Revised Estimates.-Toward the close of the third quarter of the fiscal year, namely, in December, the Treasury calls upon the principal receivers of revenue and the accounting officers to submit revised estimates of revenue and expenditure for the eurrent fiscal year, together with memoranda explaining the reason for any variations that may have oceurred between the original estimate and the 
revised estimate. When these estimates are reeeived in the Treasury. they are carefully examined in detail and such criticism is made upon the rariations as may be demanded by the cireumstances of each case. Thereafter. statements are prepared showing the total revenue to be received and the total issues to be made. When these have been completed, the financial position on the revenue account, as distinguished from the loan (or capital) account, will disclose whether there is an estimated surphlus of revenue over expenditure or a deficit in respect of that fiscal year.

Budget.--In his budget statement the Minister of Finance deals comprehensively with the position thus disclosed, mentioning the improvement, or otherwise, of imports and exports as a whole and South African produce in particular, the mining industry, manufactures, etc. The causes of the fluctuations, if any, in the revenue received from customs and excise, gold, diamonds, income tax, posts, telegraphs and telephones, etc., are also explained. If expenditure has exceeded the original estimate and further supply is required, the Minister is to explain to the House the necessity for additional moneys.

The disposal of any ascertained surplus at the close of the financial year is provided for by statute and is to be utilised to redeem public debt. In the event of a deficit being foreshadowed when the revised figures are received in December, every effort is made to curtail expenditure, more especially on services that may be termed "unessential " in order to avoid snch contingeney. During the first decade of the Union $(1910-20)$ there was a deficit in only one year (1914-15), and that was due to the violent disturbance in revenue oceasioned by the outbreak of the European War and the South African Rebellion. That deficit was charged to the Loan Account in view of the fact that surpluses are utilised to redeem debt.

The next item to be dealt with in the budget statement is the position for the ensuing financial year when the Government avails itself of the opportunity of expressing its financial policy. If a deficit is forecasted, the Minister informs Parliament of its proposals in regard to meeting this deficit. This may take the form of imposing more taxation or inereasing the rates of existing taxes or, if only a comparatively small deficit is budgetted for, making no provision for' the defieit in the hope that the revenue may improve or that expenditure may be reduced. 'There is another expedient, namely. that of transferring to the revenue account the proceeds of certain taxes. or other income, which, in the ordinary course of events, would be credited to the loan account. On the other hand, if a surplus is 
anticipated. the Government may deeide to abolish certain taxes or to give rebates or reductions upon existing taxation or to allow the surplus to materialise for the redemption of debt.

Upon the completion of the review of the finances in respect of the revenue (or current) account, the Minister deals in a similar manner with the Loan Account, which provides for the capital expenditure upon railways, harbours, telegraphs, telephones, buildings, irrigation works, eapital required for advances by the Land Bank, etc. The interest on thesc investments is credited to the revenue account, but realisations and repayments of capital are credited to the loan account.

When the Minister has eoncluded his statement, the House of Assembly is at liberty to diseuss it. After the discussion is completed the Minister replies to the debate, and thereafter the motion "that the House go into Committee of Supply" is put. If accepted, the House resolves itself into "Committee of Supply," when each expenditure vote is considered and debated until all votes are passed by the House. A Bill-the Appropriation Act-is then brought up by the Committee embolying the amounts included in the estimates of expenditure. When this Bill has been passed by the Legislative Assembly it is transmitted to the Senate for its concurrence. Upon the introduction of the Bill in the Senate, the Minister of Finance gives a resume of the budget statement made in the House of Assembly. The Bill is debated, and if passed through the usual three readings it is returned to the House of Assembly with a notification that the Bill is concurred in. It is then transmitted to His Excelleney the Govemor-General for his assent and this completes the necessary legislative action upon the Government's proposed financial measures for the year.

The statement of revenue to be collected, which is presented to Parliament, is not dealt with by the legislature, except in debate, as it only embodies the amounts estimated to be received from sources of taxation imposed by statute.

Pending the passing of the main Appropriation Act which may take two or three months to go through both Houses of Parliament, from the date of the budget speech, a Partial Appropriation Aet is passed which authorises expenditure in the new year upon the basis of the expenditure of the financial year just elosing. The power granted under these bills lapses upon the passing of the main appropriation bill. 
(2) Railway and Harbour Budget.

Provision was made in the Union Constitution for an independent railway and harbour budget. The budget statement in respect of the finances of the railways and harbours is delivered by the Winister of Railways and Harbours in the Legislative Assembly, at about the. same time that the Union budget statement is delivered by the Minister of Finance. The budgetary procedure is practically identical with that in the case of the Union budget, the Honse resolving to go into "Committee of Supply" and consictering the estimates of expenditures, ordinary and eapital. item by item.

(3) Provincial Budgets.

Provincial budgets are submitted to the Provincial Councilby the Administrators of the respective provinces, the Councit resolving itself into Committee of the whole and voting upon each item of expenditure.

The final stage is the passing of the Appropriation Ordinance by the Council, the procedure being virtually the same as in the eare of the Union budget.

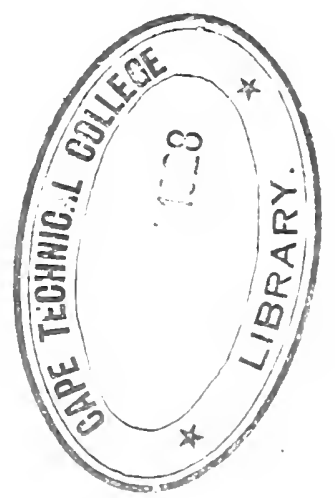


Control, of the Fixaxces.

(1) Union Fimance.

The control of the finances of the Union (exclusive of railway and larbour finance) resolves itself into four stages:

(1) the power of appropriation vested in the Union Parliament;

(2) the control over the isives from the Exchequer exercised

by the Union Treasury and the Controller and AuditorGineral ;

(3) the audit of the accounts of the Union Government conducted by the Controller and Auditor-General;

(4) the examination of the annual report of the Controller and Auditor-General and the reports of the institutions in receipt of grants from the Gorernment, by the Public Accounts Committee of the Tniom Parliament.

Appropriation.--The Union Parliament is entrusted with the power of appropriation. not only in respect of the ordinary exlenditures but also the capital or non-recurrent expenditures of the Union Government. Parliament resolves itself into "Committee of Supply" and considers each expenditure rote (estimate) until all votes are passed. Subsequently, the Appropriation Bill is introduced and the appropriations are roted on item for item.

The charges upon the Revenue and Loan Accounts are thus provided for by ammual appropriation acts, and it is only under the autholity of such an act that a withdrawal from the Consolidated Revenue Fund can take place. ${ }^{1}$

Issues from the Excheruer.- Issues on account of voted services are to be credited to accounting officers by the Treasury upon their requisitions, which are to be submitted in such form and at such times as may be prescribed. The total issucs on account of any vote are not to exceed the total of the rote as authorised by Parliament unless a special warrant has been granted by the Governor-General.

No accounting officer (with the exception of the PostmasterGeneral) is to meet expenditure chargeable against roted services in excess of the sums credited to him from time to time by the 
Treasury by drawing upon revenue or deposit moneys in his hands, and any sum temporarily advanced out of accruing revenue by the Postmaster-General is forthwith to be repaid to revenue out of the amount credited to him by the Treasury.

When issues have been sanctioned to meet the requisitions of accounting officers, each accounting officer is to be notified by the Treasury of the credit that has been granted to him with the Paymaster-General in respect of each vote. When a credit has been notified by the Treasury to an accounting officer, he may draw on the Paymaster-General against that credit. Requisitions for, and issues on account of, voted moneys are to be strictly limited to amounts required for expenditure within the period covered by the requisition. No issue is to be made from the Exchequer after the last day of a financial year under any credit granted in the financial year ending on that date ; provided that an accidental overdraft by an accounting officer on his account with the Paymaster-General may be adjusted after the close of the financial year by an issue from the Exchequer if there are available balances upon the votes concerned."

With a view to economising the public balances the Treasury is to restrict the sums to be issued or transferred from time to time to the credit of the accounts of accounting officers to such total sums as the Treasury may consider necessary for conducting the current payments for the public service entrusted to accounting officers. ${ }^{3}$

When any revenues have been appropriated by law for any specific purposes the Governor-General may, by warrant under his hand, authorise and require the Treasury to issue to the accounting officer's concerned, out of the credits on the Exchequer Account to be granted to the Treasury by the Controller and Auditor-General, the sums which may be required from time to time to meet the cost of the said purposes, not exceeding the total of the moneys so appropriated. If, however, it appears to the Governor-General to be necessary in the public interest that an issue should be made from the Exchequer Account to defiay unforeseen expenditure of a speeial charaeter which is not provided for in an Appropriation Aet, and which cannot, without serious injury to the public interest, be postponed until adequate provision can be made therefor by Parliament, or to meet an excess on a vote of Parliament, the Governor-General may. by special warrant

Financial Regulations, pp. 11.12.

3 Act 21 of 1911 , sec, 22.2. 
under his hand, and in antieipation of the approval of Parliament, authorise the Treasury to issue to the accounting officers coneerned the amounts required; provided that:

(a) the total sum authorised in anticipation of Parliamentary approval is not at any time to exceed $£ 300,000$;

(b) the sums issued are to be submitted for appropriation by Parliament not later than during the following session, if Parliament is not in session at the time;

(c) no contract involving expenditure in excess of an amount of $£ 10,000$ upon any work or building, for which provision is not made in a vote of Parliament or by a special warrant, is valid or binding upon the Government until it has lain for one month upon the table of the House of Assembly without disapproval. ${ }^{4}$

All amounts issued from the Exchequer Aecount out of the credits granted to the Treasury by the Controller and AuditorGeneral are to be credited by the bank to the Paymaster-General's Aceount, and by the Treasury in its records of the said aceount to the aceounting officers responsible for the votes or services affected."

If at any time it appears that the moneys in the Revenue Aceount are likely to be insuffieient to defray the authorised charges upon that account, the Treasury is to preparc and submit to the Controller and Auditor-General a statement showing the amount of the estimated deficieney, and if he is satisfied that there is a likelihood of such a deficieney arising, he is to certify the amount thereof, whereupon the Treasury may obtain advances by means of Treasury bills or otherwise. All such advanees are to be plaeed to the credit of the Exehequer Aecount and are to be available for issues. The principal of any such advances together with the interest thereon are to be repaid out of the growing balance of the Exchequer Account. ${ }^{6}$

The provision for expenditure included in any Appropriation Act or in any Special Warrant is not to be deemed to confer upon accounting officers authority to expend the full amount of the sums so granted, but are to be regarded as indicating the maximum amount that may be devoted to the services specified; and it is within the power of the Treasury to limit or suspend expenditure provided in those ways if the exigencies of the financial situation render it desirable. All such limitations or suspensions of ex-

4 Act 21 of 1911 , sec. 26 .

5 Ibid, sec. 31.

E Act 21 of 1911 , sec. :32. 
penditure are to be recorded in the Treasury, and the controllex and Auditor-Cieneral is to be notified thereof.

Audit.-Provision has been made for an claborate sytem of audit under the direction of an independent officer, designated the Controller and Auditor-General, whose appointment by the Union Govermment was provided for in the Union Constitution. This officer can only be removed by the Government. when an address praying for such removal is presented to the forernorGeneral by both Houses of Parliament. He may inclecel be temporarily suspended by the Govermment on the ground of incompetence or misbehaviour, when Parliament is not in sexion; but in order to be valid and final such suspension requires the confirmation of both Houses of Parliament. A full statement of the circumstances is to be submitted to both Houses of Parliament within fourteen days after the commencement of its next sesion. If an address is presented to the Government by both Houses praying for the reinstatement of that officer, he is to be reinstated accordingly; otherwise the Governor-General shall declare the office vacant.

The Controller and Auditor-General is, therefore. independent of the Govermment but responsible to Parliament. This is an essential requisite of an effective system of audit control. 'The Auditor-General is entrusted with the examination and audit of the accounts of all accounting officers and of all persons responsible for the receipt, custody, or issue of public moneys, stamps, securities and stores.

It is the duty of the Auditor-General to satisfy himself-

(a) that all reasonable precautions have been taken to safeguard the proper collection of public moneys, and that the laws and regulations relating thereto have been duly observed;

(b) that all issues and payments are made in accordance with the proper authority and are supported by sufficient voncher's or proof of payment.

However, the Auditor-General may, in the examination of any accounts, admit and allow in cases where it appears to him to be reasonable and expedient, vouchers for any moneys expressed therein, although those vouchers are not stamped as required by law ; and where a voucher is defective in any respect or has been lost or destroyed, the Treasury, if sati-ficr with the explanation given by the responsible officer, may make such order as in the

7 Financial Regulations, [). $1 \%$. 8.S.A. ACt, soc. $1: 32$. 
eircumstances may appear necessary, either dispensing with the production of a voucher or otherwise, and every such order is to be accepted by the Auditor-General."

In the exercise of his powers and duties the Auditor-General may, by notice in writing, require any officer in the public service to appear before him at a time and place named in the notice, and to produce to him all such records, books, vouchers and documents in the possession and control of such officer as may appear necessary.

As soon as possible after the aceounts have been closed in respect of any financial year, the Treasury is to prepare statements of :

(a) the Exchequer Account;

(b) the Revenue Account:

(c) receipts and payments in respect of loans:

(d) all other funds of which the Treasury may have charge:

(e) the amount of the public debt of the Union and the annual charge thereon and showing also the amount of debt created and redeemed in the financial year;

(f) the purposes to which the jublie debt of the Union has been appliecl.

These statements are to be tran-mitted to the Auditor-General for examination. ${ }^{10}$

Likewise, within three month. after the elose of any financial year, accounts of the appropriation of all the services comprised in any Appropriation Act of that financial year are to be prepared by the accounting offices and transmitted for examination to the Auditor-Gencral, who is to examine these ". appropriation accounts" and to transmit them, together with his certificate and a report signed by him, to the Minister of Finance, and the Minister is to present the accounts and the report to both Houses of Parliament. ${ }^{11}$

In reporting on the appropriation accounts. the Auditor-General is to call attention to:

(a) every case in which it appear's to him that a grant has been exceeded or has been applied to any service or for any purpose other than that for which it was intended;

(b) any special question of audit arising out of the aceounts;

(c) any expenditure which appears to him to have been incurred without the anthority of the Treasury. ${ }^{12}$

3 Act 21 oi 1911 , ser. 13.

10 Act 21 of 1911 , sec. 36 .
11 Ibid, secs. $37-40$.

12 Act 21 of 1911 , sec. 41 . 
Summing up, then, the Controller and Auditor-General is an officer of Parliament independent of the Government, and it is his duty as Auditor to call attention to any expenditure not authorised by Vote of Parliament, or any irregular or improper expenditure, or expenditure ealling for special account. The examination of the Public Accounts is directed with a view to exposing cases of extravagance and waste, preventing and detecting fraud, and securing sound accounting in aecordance with recognised principle. In fact. the Auditor-General is the watch dog of Parliament so far as expenditme is concerned.

For the purpose of conducting the audit of th accounts of th" Union Government an elaborate establishment, composed of 140 members, has been instituter. Subject to the Minister of Finance, the staff engaged in the audit of accounts is under the control of the Controller and Auditor-General.

Public Accounts Committee.-The Public Accounts Committee is appointed regularly at the commencement of every session of Parliament, and its special work is to examine the report of the Controller and Auditor-General on the cxpenditures of the Government during the preceding financial year. The annual report: of institutions which are in receipt of grants from the Union Government are also referled to the Committee for examination and report.

The members of the Public Accounts Committee examine the report of the Auditor-General in considerable detail. In going through the report on any department they have before them the accounting officer for that department, who is called upon to explain any matter which in the opinion of the Committee requires explanation. The committee then reports to Parliament on all matters brought up in the report of the Auditor-General to which in their opinion the attention of Parliament should be directed.

The chief function of the committee is to check improper or irregular expenditure, which it does very effectively by reportings to Parliament and thereby making such expenditure public. According to the testimony of a former chairman of the committer. there is no Government in the world where there is less of that sort of expenditure than in South Africa.

However, the Public Accounts Committce and the Controller and Auditor-General have no control over any expenditure sanctioned by Parliament. If the Government supported by Parliament is extravagant, that committee cannot check it. 
Comparison with the United Kingrom.-The financial system of the Union is in its main prineiples based upon that of the United Kingtom. There are, however, two important differences:

(a) The United Kingrlom has a system of "appropriationin-aid," which are reeeipts relative to the particular vote in aid of which they are appropriated. Thereby inflation of both sides of the account is avoided, only the net expenditure being shown in the finance accomts. In the Union, however, such receipts are credited to revenue and cannot be utilised without appropriation by Parliament. Though this has a tendency to swell both the receipts and expenditure sides of the account, it is considered that more effective Parliamentary eontrol is obtained by this method ;

(b) In the United Kingdom there is a large amount of expenditure whieh is a permanent eharge upon the Consolidated Fund. This expenditure, which is permanently appropriated by Aet of Parliament and of which the chief item represents publie debt charges, is not inchuded in the Supply Acts. In the Union all the expenditure for the financial year is included in the annual appropriation acts, in order that the financial position of the comtry may be clearly set before Parliament.

Comparison with Canada.-In the Dominion of Canada the same principles are in vogue as in the Union of South Africa, with one important exception. The Canadian Government has unlimited power to obtain by means of a warrant of the Governor-General funds for expenditure over and above that authorised by Parliament, whereas in the Inion the control in this direction is much more effective, a sum of $\$ 300,000$ being the limit set to the expenditure which the Government is permitted to make in antieipation of the sanction of Parliament.

\section{(2) Railerey ame Harbour Finance.}

In respeet of railway and harbour finanec the power of appropriation is likewise vested in the Union Parliament, and provision is also made for unforeseen expenditure.

With a view to enabling the Railway Administration to ineur expenditure on such unforeseen services as camnot be postponed without serious injury to the public interest until adequate provision therefor ean be made: by Parliament, the Governor-General is empowered to authorise the Administration by special warrant to incur such expenditure not exceding in the aggregate the sum of $f 30 g, g(t)$ in one year. or the amount by whieh the acerued earnings 
of the Administration, caleulated to the last day of the month immediately preceding the day on which the special warrant is issued, is in excess of the proportion of the earnings caleulated to the said day on the basis of the estimate of revenues at the commencement of the financial year (in other words, the amount by which the actual revenue exceeds the estimated revenue), whichever amount is the greater. ${ }^{13}$ The amount allowed for unforeseen expenditure was inereased to $£ 500,000$ in 1922. ${ }^{1 \text { t }}$

In a large concern such as the South African Railways there is every likelihood of instanees arising where it is not possible to foresee the necessity for certain expenditure being incurred. The Administration may be confronted with an unprecedented volume of traffie to be handled which could not have been foreseen, thereby necessitating an expenditure in running trains far in exeess of the amount authorised by Parliament. It would be detrimental to the interests of the eommunity to wait until the authority of Parliament could be obtained to expend moneys on this service, and for this reason the latitude mentioned is provided for.

In order to facilitate the lubrication of the railway mechanism, authority to incur expenditure at their discretion is delegated to subordinate officials, and this is aecomplished by fixing specific emounts up to which they are authorised to incur expenditure without previously obtaining the sanction of the General Manager. The amounts vary in every instance aceording to what is considered the maximum latitude that should be allowed to these subordinate ofticials.

The railway and harbour finances are not subject to the control of the Treasury as in the ease of the financial operations of the other State departments. The railways and harbours eonstitute an independent organisation. and subject to the authority of the Minister of Railways and Harbours the General Manager is the responsible head.

The expenditure of the department of railways and harbours is liable to audit and examination by the Controller and AuditorGeneral. Within three months after the elose of any financial year the accounting officer of the Railway and Harbour Administration is to prepare and render to the Auditor-General accounts and statements, showing the true finaneial position of the railways and harbours in respeet of that financial year. The AuditorGeneral is to certify that he has examined the accounts and is to transmit them with his report thereon to theylinister of Railways

13 Ant 21 of 1911 , ser. 4i. 
and Harbours. who is to present all such accounts and reports to both Houses of Parliament. ${ }^{15}$ In this annual report the AuditorGeneral is to draw attention to expenditure which he considers does not fall within the appropriations authorised by Parliament, and also to instances where the appropriations have been exceeded, which in turn necessitates Parliament voting the additional sum provided it is satisfied that the expenditure was justified.

The report of the Auditor-General on the railway and harbour accounts is referred to the Select Committee on Railways and Harbours for examination. This Committee is appointed at the commencement of each session of Parliament. The main function of this committee, as of the Public Accounts Committee, is to check irregular and improper expenditure by calling the attention of Parliament theretr.

\section{(3) Provincial Finance.}

In respect of provincial finance the power of appropriation is vested in the Provincial Council, and no money is to be issued from the provincial revenue fund exeept in accordance with the appropriations authorised by the Council. However, the Administrator of any Province may, by special warrant under his hand, authorise the issue of moneys from the revenue fund to defray unforeseen expenditure of a special character which is not provided for in an Appropriation Ordinance and which cannot without serious injury to the public interest be postponed until adequate provision (an be made therefor by the Council. or to meet an excess on a vote of the Council. The total sum which an Administrator may authorise in this way in respect of any Province is not at any time to exceed $\{25,000$, and the relative expenditure is to be submitted to the Comneil for appropriation not later than during the following ression. ${ }^{15}$

Adequate provision is made in the Union Constitution for the audit of provincial accounts. In each Province there is an auditor of accounts appointed by the Union Government. It is the duty of this officer to examine and audit the accounts of the province to which he is assigned subject to such regulations and orders as may be framed by the Government and approved by Parliament, and no warrant signed by the Administrator authorising the issue of money is to have effect unless it is countersigned by the auditor. ${ }^{2-}$

15 Act 21 of 1911 , secs. $50-51$ and Ar.t 31 of 1916 , sec. 16 .

It Act 10 of 1913 , sec. 17 .

3 S.A. Act, sec. 92. 


\section{CONCLUSIONS.}

The decade from 1910 to 1920 has been an exceptionally unsettled period in South African finance as the result of the operation of several important factors. In the first place, the establishment of the Union of the four Colonies in 1910 involved a partial reorganisation of the Colonial departments. In the ease of certain items of expenditure, such as expenditures on agriculture, financial administration, police, mines and industries, economies were effected by the consolidation of four Colonial departments into one Union department; but in general there was a small inerease in view of greater activity and the broader interpretation of departmental functions.

Secondly, the outbreak of the European War in July, 1914, followed by the South African Rebellion, occasioned a serious disturbance in trade and industry and, in consequence, a substantial reduction in revenue. This necessitated the adoption of a policy of economy and retrenchment wherever possible. The fiscal year 1914-15 closed with a deficit of $\{2,012,000$, so that economy was to be applied with equal vigour in 1915-16. Increased taxation was resorted to, reflected in the extension of the income tax and the imposition of two special war levies of $\mathfrak{f 5 0 0 , 0 0 0}$ each in 1915 and 1916 and an export duty on diamonds. The year $1915-16$ yielded a surplus of $£ 397,918$, and as the revival of trade and industry, together with the full operation of the new taxes, was expected to effect a considerable increase in revenue, the rigid economy was somewhat relaxed. The outcome of this economy. was (1) a reduction, during the first two years of the war, in those expenditures which afford scope for retrenchment in the case of an emergency, without undue sacrifice, such as constitutional expenditure and expenditures for public works and buildings, justice, agriculture, etc.; and (2) a check on the normal growth of expenditures for services which are essentially subject to annual inerease, such as primary and secondary education, public health, care of the dependent and defective classes, prisons and reformatories.

Thirdly, the enhanced eost of living and of materials eaused a large advance in expenditure after 1917. The war bonus was first instituted in June, 1916. It was paid at a flat rate of 25s. per month to all married officers in receipt of less than $£ 240$ per annum, increased in April, 1917, to 35s. per month and extended to married officers in receipt of salaries up to $£ 300$ per annum, and again increased in November, 1917, to 50s. per month and 
made payable to married officers drawing up to $£ \notin 80$ per annum. The war bonus was continued on this basis until the lst April, 1918 , from which date effect was given to certain recommendations made by the Commission of Inquiry which had been appointed by the Union Govermment to investigate the question of salaries and wages in the Public Service, and particularly the need for a revised war bonus. Under the new system the war bonus was extended to ummarried officials as well as to those whose emoluments exceeded $\mathscr{E} 480$ per annum, and a sliding scale was adopted in respect of the married officials, the amount of the bonus rising in proportion to the amount of the salary and the increase in the cost of living subsequent to that date. Furthermore, in 1919 the Commission recommenderl a gencral increase in the scale of pay on the ground that salaries were fixed on too low a basis on reorganisation in 1912. The pre-war salary of $£ 240$ per annum was permanently increased by $£: 30$ per annum, with a commensurate addition to salaries above and below that figure.

Prior to 1918 the war bonus did not represent a heavy burden on revenue on account of the small amount and the limited seope of its application. but the introduction of the revised bonus system in 1918 entailed a considerable increase in expenditure. The following table indicates the growth in expenditure in respect of war bonus allowances in the Union Public Service (exclusive of railways and harbours) and the Provincial Services.

$$
\text { War bones Expexditukl. }
$$

Expenditure in

Fiscal Year. Union Service.

$\mathfrak{f}$

1916.17

1917.18

$1915-19$

1919.20

Expenditures.

Thus, from the view point of progression or retrogression the expenditures may be grouped in three classes:

(1) those expenditures which were subject to decrease during the initial years of the Union as the result of economies effected by the reorganization of the Colonial departments and their consolidation into one Union department;

(2) those expenditures which were subject to decrease during the first two years of the War (the financial vears 1914-15

Aulitor-(ieneral's Report for 1919-20, pp. 36.37, and Comparative Summary of Expenditure issued by Treasury in 1920 . 
and 1915-16) as compared with the figures for 1913-14including the expenditures in class I. which were capable of further reduction, in consequence of the necessity to secure economy :

(3) those expenditures which show a continuous increase during the whole decade in view of their strong natural tendeney to advance with the growth of population and the progrese of civilization-an increase which was held in check during the first two years of the War but was accentuated during the latter part of the decade by the effects of the andancerl cost of living and of materials.

Expenditures subject to decrease in first two years of Union.

Financial Administration. Agrieulture l'roper.

Police.

Promotion and Rerulation of Industry.
Expenditures sulijert to deerease during first two years of War.

Constitutional Expendi. ture.

I'ublic Works and Buildings.

Financial Administration.

Agriculture Proper.

Agricultural Eduration.

Higher Education.

Justice Proper.

Promotion and Regula. tiou of Industry.

Sative Affairs.
Fispenclitures subject to continuons increise.

National Defence.

Primury and secondary Elucation.

Public Health.

Dependent and Defertivo C'lasses.

Irisons and Reforizd. tories.

Public Dolst C'harent.

The following table serves as a summary of the ordinary expenditures (excluding commereial expenditures) for the rear 1911-12 and 1919-20.

Head of Expenditure.

Constitutional Expenditure.

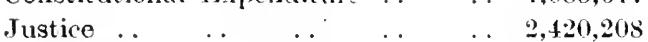

Fducation $\quad \ldots \quad \ldots \ldots+1,74,596$

Public Works and Buildings _. 1,656,549

$\begin{array}{llllll}\text { Agriculture } & \ldots & \ldots & \ldots & \ldots & 627.351\end{array}$

Dependent and Defeetive Classen .. 519,166

National Defence $\quad \ldots \quad \ldots \quad \ldots \quad \ldots \quad 456,707$

Financial Administration $\quad \ldots \quad \ldots \quad 296,180$

Native Aftairs . . . . . . .

Promotion and Regulation of Industry

Public Health

287,482

190,848

101,453

Public: Debt Charge . . . . . . $1,848,058$

Miscellaneous Expenditure . . . . 180,422

$$
\text { Total } \quad \ldots \quad \ldots \notin 11,+18,637
$$

Percentage

Pereentage 919-20. of Total.

\begin{tabular}{|c|c|c|}
\hline tal. & $9-20$. & $10 t 8$ \\
\hline$\%_{0}^{\prime}$ & $\dot{t}$ & $\%$ \\
\hline 9.4 & $1,809,510$ & 8.9 \\
\hline 21.2 & $3,592,754$ & 17.6 \\
\hline $15 . ;$ & $4,762,11 j$ & 29.4 \\
\hline 14.5 & $1,574.495$ & 7.7 \\
\hline 5.5 & 674.691 & 3.3 \\
\hline 4.5 & $1,078,04: 3$ & 5.3 \\
\hline 4.1$)$ & $2,276,065 ;$ & 11.2 \\
\hline 2.6 & 384,$581 ;$ & 1.9 \\
\hline 2.6 & 414.05 .15 & 2.0 \\
\hline 1.7 & 294.877 & 1.5 \\
\hline .9 & 234,$1114 ;$ & 1.1 \\
\hline 16.2 & $3,011,(1,211$ & 14.8 \\
\hline 1.6 & $267,76.5$ & 1.3 \\
\hline 0.0 & $1: 34$ & 100.0 \\
\hline
\end{tabular}


It will be observed in the foregoing table that all the items of expenditure; with the exception of public works and buildings, show an absolute increase, whereas only the expenditures on education, the dependent and defective classes, national defence, and public health show a relative increase.

During the period from 1911-12 to 1919-20 the total expenditure was subject to an increase of 82 per cent., but the per capita expenditure in respect of the white population adranced only 57 per cent., and that in respect of the total population 53 per cent.; namely,

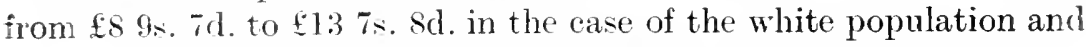

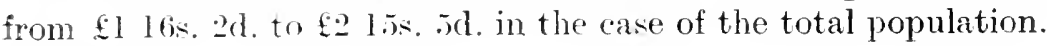

\section{Rerenues.}

In accordance with the requirements of scientific classification, the revenues have been grouped under three main heads:

(1) Commercial Revenue ;

(2) Administrative Rerenue:

(3) Revenuc from Taxation.

\section{(1) Commercial Revenue.}

(a) Industries.-The industrial undertakings of the Union Gorernment vield no net revenue, i.e. revenue in the form of a profit, to the Union Treasury. On the contrary. they involve a small net loss.

In the first place. the railways, harbours, and steamships are managed independently and are not subject to the authority of the Treasury. During the first three rears of the Union, the sum of $\{3,179,000$ was paid orer to the Treasury out of the net earnings of the railways. but since the readjustment of the railway finances, -o as to conform to the cost principle specified in the Constitution and pay expenses merely. was effected in 1913, the railways and harbours are practically isolated from the Lnion finance proper. Under the present regime, any surplus that is earned by these three enterprises is to be paid into the Railway and Harbour equalization fund, and any deficit that may be incurred in connection with the operation thereof is to be met out of that fund, or, as was necessitated by the depletion of the fund during the war and by the continuance of abnormal conditions after the war. out of funds borrowed from the Treasury. The deficits incurred by the Railway and Harbour Administration in recent years do not represent a burden upon taxation, but are to be defrayed out of future earnings.

Secondly, the operation of the post office, telegraphs, and telephones of the Cuion results in a small deficit, as a general rule. In some years, as in 1911-12 and 1919-20, the deficit would be comparatively large if business methods of accounting were applied, 
since in those years the revenue was hardly sufficient to pay the operating expenses; but, taking the whole decade as a basis, the amount that was to be paid out of taxation on behalf of the postal, telegraph, and telephone services might be estimated to be relatively small.

Finally, in the ease of the Post Office Savings Bank and the Land Bank, the net surplus that is a regular onteome of their financial operations is not available for appropriation by Parliament, but is assigned to their respective reserve funds. The Land Bank, moreover involves a slight loss to the Treasury inasmuch as the advanees to the bank by the Treasury, subsequent in 1914. were made at the rate of 4 per cent., whereas the rates of interest on the loans of the Union Government sinee 1915 have been $4 \frac{1}{2}$ and 5 per cent.

Thus, the operation of the industrial enterprises of the Union Government imposes a burden on the taxpaying eonmunity, it burden which is the result of publie policy and which is eomparatively small when taking into consideration the fact that the State was obliged to undertake the development of the modern facilities of transportation and communication, on account of the laek of private initiative and the scant prospects of rendering snch industries profitable in a country of vast area with a sparse population.

However, the Treasury reeeives annually from the Railway and Harbour Administration an amount of about $\$ 450,000$ as interest

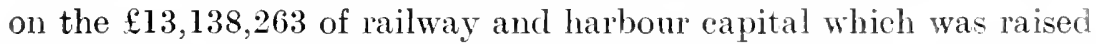
from general revenue by the Colonies prior to the Union; and this may be classified as an item of commercial revenue.

(b) Domains.-In view of the fact that the accomnting procerlure is not in accordance with the requirements of scientific finance and that, as a result, it is impossible to secure an accurate computation of the net revenue from domains, it is necessary to resort to approximate and average figures, in the attempt to arrive at an estimate of such net revenue. The following table represents the results of a proeess of computing the approximate average surplus or deficit during the deeade in respeet of each of the five sub-divisions of domains, and deriving from this the approximate arerage ammual net revenue from domains in general:

$$
\text { Classification. }
$$

Crown Lands and Land Settlement

Mining Lands and Mining Rights

Irrigation and Conservation of Water

Forestry

Guano Islands

$\cdots$
$\cdots$
$\cdots$
$\cdots$
$\cdots$

$$
\text { surplus. }
$$$$
\mathfrak{f}
$$$$
190,000
$$$$
1,000,000
$$

40.000
Deficit \&

$1: 0,000$ 60,000 
(c) Investments.-.The revenue from investments, comprising interest on the cash balances and the surplus interest in connection with the investment of the so-called guardians' funds. varies from about $£ 120.000$ to $\$ 150,000$ per annum.

\section{(2) Administiatice Revenue.}

Administrative revenue is not of much significance in South Africa. The most important items are fees and miscellaneous departmental receipts, which together represent about two-thirds of the total administrative revenue.

\section{(3) Taxation.}

Taxation provides the great bulk of the revenue. the most prorluctive taxes leeing the customs and the income tax, the former vielding in 1919-20 26.7 per cent. of the total net ordinary revenue and the latter 20 per cent. In 1912-13 taxation yielded 76.3 per cent. of the total net ordinary revenue whereas by 1919-20 the proportion had risen to 86 per cent.

The requirements of a well-balanced tax system have been atisfactorily complied with in South Africa. In the first place, the taxes levied on property or ineome, such as the income and excess profits taxes. inheritance tax, etc., effect a distribution of the burden of taxation with some approximation to ability to pay, while the so-called consumption taxes, such as the customs and excise and the export duty on diamonds, reach the tax-paying capacity of people, individually possessing property or income in amounts too small to be effectively tapped by property and income taxes, but into whose hands pases a very large part of the national income.

In general, the consumption taxes yield about 50 per cent. of the total revenue from taxation for the Union and the Provinces and the froperty and income taxes from 30 to 35 per cent., the remainder being accounted for by taxes on transactions, legal and commercial locuments, the pursuit of specified occupations, and polls. The regresive character of consumption taxes is. to a great extent, offset by the exemptions and progressive rates of the income tax, and the imposition of excise duties mainly on luxuries or on articles the consumption of which can be curtailed without real injury or I erhaps eren with benefit.

Secondly, in accordance with the modern interpretation of ability and equality in taxation, provision has been made for progression in the income tax not only by means of an elaborate system of primary and secondary abatements, but also by means of progressive rates in the case of the normal tax on individuals and the super tax. 
The progression has been rendered degressive by the abatements as well as by the limitation of progressive rates to an income of $\mathfrak{f 2 4 , 0 0 0}$ in the normal tax and $\mathfrak{f} 48,000$ in the super tax. The high

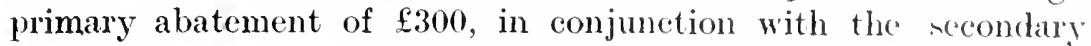
abatements for children, insurance premiums, ctc., was amply justified by the large yield of the consumption taxes which press most heavily on the smaller incomes.

Thirdly, although no provision has been made in the income tax for the differentiation of funded and unfunded incomes or of unearned and earned incomes, as in England, and although there is no supplementary national or provincial property tax (with the exception of the nominal land tax in the Transval and the Orange Free state and the recently-imposed tax on immovable property in the Cape of Good Hope) as an alternative of specific differentiation. as in Germany, the desired effect is obtained in large measure through the local rates on immovable property which render income from such property subject to a higher rate of taxation than ineome lerived primarily from personal exertion.

Thus the two main principles of justice in the distribution of the public charges, namely those of uniformity and universality, have been incorporated in the South African tax system.

The determination of the relative fiscal significance of the three main classes of revenue and of their subdivisions is a comparatively difficult task, in view of the fact that the system of accomnting does not permit of the accurate computation of the net commercial revenue by the simple method of dedueting gross expenditures from gross revenues in respect of the commercial actirities of the Union Government. With the exception of the railways and harbours which are managed aceording to business practices and treated in a separate budget, the accounting in the government departments or sub-departments in charge of commercial activities is conducted not with a view to showing the net surplus or defieit in each case, but mainly to furnish the requisite material for the Union budget and to comply with the requirements of the existing organization. For example, the Department of Public Works is entrusted with the erection, equipment, and maintenance of public offices and institutions for the Union, and the provision of accommodation and other services for all departments. Such expenditure is charged to the Department of Public Works and not to the department for which the service was performerl. Any department requiring a service which another department is specially charged to perform is to requisition on that department for the performances of the service.

The budgetary statement presents revenues and expenditures under general heads, wherever possible. In the case of interest. 
all interest receivable by the Treasury is included under the general revenue head of "interest," and all interest payable by the Treasury on outstanding loans is included under the general expenditure head of "interest." Likewise, the item "land revenue" covers the revenue from land taxes as well as the revenue from quitrents on Crown land. The accounting procedure is adapted to this practice.

However. the net commercial revenue can be calculated by the application of the common accounting device of credits and debits, i.e. by putting on the one side the non-commercial revenues (administrative revenue and revenue from taxation) and the deficits of the Union and of the Provinces (if any), and on the other side the nonconmercial expenditures and the surpluses of the Union and of the Provinces (if any), the difference constituting the net commercial revenue. By way of exemplification, the following is the procedure adopted in ascertaining the net ordinary commercial revenue for 1919-20:

Administrative Revenue .. $\quad \stackrel{\mathfrak{E}}{1,488,621}$

Revenue from Taxation . 20.223,970

Net Commercial Pievenue 1.792,532

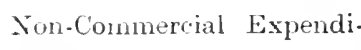

Total
$£$
374,034
460,426
670,663
505,123

The adoption of this method has rendered possible the construction of the following table, showing the relative fiscal significance of the three main classes of revenue.

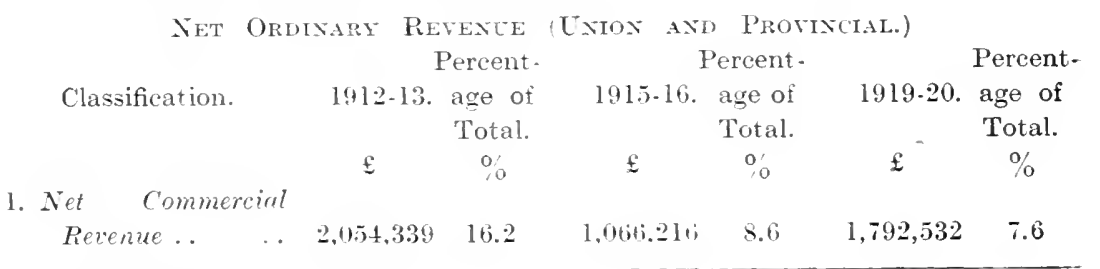

2. Administrative

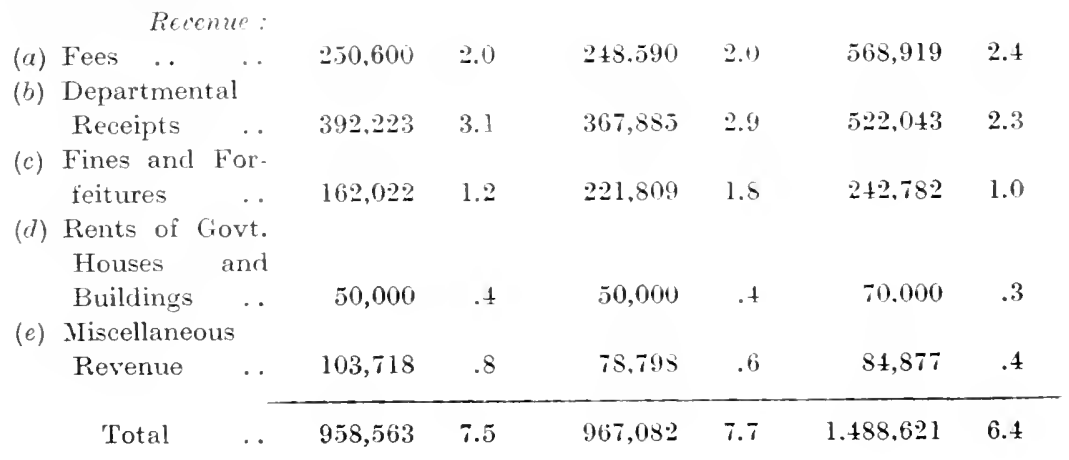


3. Revenue from Traxa. tion.

\begin{tabular}{|c|c|c|c|c|c|c|c|}
\hline$(a)$ & Customs & +.634 .929 & 36.5 & $4.744,6901$ & $: 30.0$ & $(i, 288,324$ & 26.7 \\
\hline (b) & Excise & 495,038 & 3.9 & 806.191 & (i..) & $1,648,159$ & 7.0 \\
\hline (e) & Income Taxes & - & & $1,(128.95: 3$ & 8.3 & $4,696,435$ & 20.0 \\
\hline (d) & Excess Profits & & & & & & \\
\hline & $\operatorname{Tax} \ldots$ & - & & - & & $1.215,996$ & 5.2 \\
\hline (e) & Mining Taxes.. & $1,478,007$ & $11.6 \mathrm{i}$ & $1,282.659$ & 10.3 & $1,319,149$ & 5.6 \\
\hline (f) & Native Taxes & $1,200,256$ & 9.4 & $1,222,501$ & 9.9 & $1,222.152$ & 5.2 \\
\hline (g) & Inheritance Tax & +17.881 & 3.3 & 156,186 & 1.5 & 282.506 & 1.2 \\
\hline (h) & Transfer Duty & 538,187 & 4.2 & 235,490 & 1.9 & 969,162 & 4.1 \\
\hline (i) & Land Tax & $40,8.56$ & $\therefore$ & 40,851 & .3 & 40.000 & $\therefore$ \\
\hline & Provincial Taxes & & & & & & \\
\hline & Proper ${ }^{2}$ & - & & 46,058 & .4 & $1.114,719$ & 4.7 \\
\hline (k) & Licences & 528.623 & 1.2 & 493,184 & 3.9 & 778,769 & 3.3 \\
\hline (I) & Stamp Duties & 368,920 & 2.9 & 336,564 & 2.7 & 658.399 & 2.8 \\
\hline & Total & $9,702.903$ & 76.3 & $10,423,361$ & 83.7 & $20,223,970$ & 86.0 \\
\hline & Grand Total & $12,715,805$ & 100 & $12,456,659$ & 100 & $23,505,123$ & 100 \\
\hline
\end{tabular}

In respect of the commercial revenue, the high figure for 191213 is to be attributed to the contribution of $£ 500,000$ from the Railway and Harbour Fund out of the profits for the year, and the low figure for 1915-16 is the result mainly of the depression in the diamond-mining industry. This implies merely the net ordinary commercial revenue and does not take account of such commercial revenues as were assigned to the Loan Account after 1917 to meet capital expenditure, namely, the proceeds from the sale of Crown lands and from the leasing of public diggings and "bewaarplaatsen."

The administrative revenues were subject to an increase of more than 50 per cent. during the period from 1912-13 to 1919-20, and the revenues from taxation were more than doubled. The most significant changes were $(a)$ the introduction and elaboration of income taxes; (b) the remarkable growth of direct taxation by the Provinces; and $(c)$ the extension of the excise system. The phenomenal increase of almost 90 per cent. in the revenues during this period of 7 years was necessitated by the enormous advance in the expenditures, due to the increased cost of living and of supplies and to the interest on the war debt.

2 These do not include the general licence taxes levied by the Provinces, such being classed with licences in gencral. 


\section{Comparative Summary of Revenues and Expenditures.}

The following table serves as a comparative summary of the gross ordinary revenues and expenditures of the Union, the Provinces, and the railways and harbours in five alternate financial years during the deeade from 1910 to 1920 .

$\begin{array}{cccccc}\text { Heading. } & 1911-12 . & 1913-14 . & 1915-16 . & 1917-18 . & 1919-20 . \\ & \mathfrak{f} & \mathfrak{f} & \mathfrak{L} & \mathfrak{f} & \mathfrak{f}\end{array}$

(1) Union.

Gross Revenues .. $\quad \ldots \quad 17,228,418$ 15,805,076 $16.556,397 \quad 19,657,597 \quad 26,885,957$ Gross Expenditures

. $16,547,381 \quad 16,492,612 \quad 16,158,479 \quad 18,959,198 \quad 24,425,531$

Surplus or Deficit . $\quad 681,037 \quad-687,536 \quad 397,918 \quad 698,399 \quad 2,460,4: 6$ (

(2) Provinces.

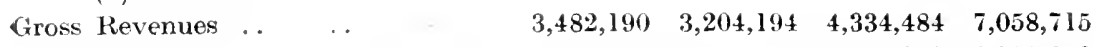

Gross Expenditures $\quad \ldots \quad 3,324,136 \quad 3,365,705 \quad 4,255,051 \quad 6,388,052$

$\begin{array}{lllll}\text { Surplus or Deficit } \ldots & 158,054 & -161.511 & 79,433 & 670,663\end{array}$

(3) Railureys de Harbours.

Gross Revenue .. . . $13,226,666 \quad 13,484,375 \quad 13,768,736 \quad 15,726,613 \quad 20,854,877$

Gross Expenditure . $11,686,608$ 14,012,141 12,411,379 15,957,879 21,453,775

SurpIus or Deficit . $\quad 1,540,058 \quad-527,766 \quad 1,357,357 \quad-231,266 \quad-598,898$

Total Surplus or Deficit $\quad 2,221,095-1,057,248 \quad 1,593,764 \quad 546,566 \quad 2,532,191$

The results of the financial operations for the entire decade (i.e. from 1910-11 to 1919-20) may be summed up as follows:

Heading.

Net Surplus.

E

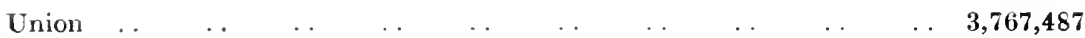

$\begin{array}{lllllllll}\text { Railways and Harbours } & \ldots & \ldots & \ldots & \ldots & \ldots & \ldots & \ldots & \mathbf{1 , 4 7 4 , 7 4 1}\end{array}$

$\begin{array}{lllllllllll}\text { Provinces } & \ldots & \ldots & \ldots & \ldots & \ldots & \ldots & \ldots & \ldots & \ldots & 711,982\end{array}$

Total . $\quad \ldots \quad \ldots \quad \ldots \mathfrak{£ 5 , 9 5 4 , 2 1 0}$

Public Debt.

The gross debt was increased by about 50 per cent. during the decade. from $£ 116,036,978$ to $£ 173,905,000$. The bulk of the expenditure from loan funds was incurred in connection with the war and the railways and harbours. By adopting the incidenee of the interest charges as the only appropriate basis for determining the relation between the reproductive and the unproduetive debt, the public debt of the Union on the 31st Mareh, 1920 was found to be composed of a reproductive debt of 61 per cent. and an unproductive debt of 39 per cent. It was also observed that there 
had been a marked change in the relation between the foreign and the domestic debt. In 1910 the domestic debt comprised merely s.:3 per cent. of the total debt, whereas by 1920 it had adranced to 29.1 per cent.

\section{Financial Administration and Control.}

The financial system of the Union is in its main principles bitcol upon that of the United Kingdom, such as the centralization of responsibility for the budget in the Government, the establishment of an independent Treasury Department entrusted with the supervision of the financial operations of all Government departments, the vesting of the power of appropriation in Parliament, the control orer the issues from the Exchequer by the Treasury and the Controller and Auditor-General, the audit of accounts by the Auditor-General who is an independent officer and acts as the watch-dog of Parliament, and the examination of the annual report of the Auditor-General by a select Committee of Parliament known as the Public Accounts Committee.

There are, however, two important differences:

(a) The United Kingdom has a system of " appropriation-in-aid" which are receipts relative to the particular vote in aid of which they are appropriated, whereas in the Union such receipts are credited to revenue and cannot be utilined without appropriation by Parliament.

(b) In the United Kingdom there is a large amount of expenditure which is a permanent charge upon the Consolidated Fund, but in the Union all the expenditure for the financial year is included in the anmual appropriation acts in order that the financial position of the country may be clearly set befor' Parliament. 


\section{APPENDIX}

Gexeral Survey of the Finaxces of the Lyion of South AFriCA FROM 1910 TO 19:2.

In the foregoing pages the finances during the first decade of the Union have been analysed in detail, and this appendix purports to he a brief summary of South African finance during the entire periorl from 1910 to 1922 , with special reference to the finaneial year's 1920-21 and 1921-2.y.

(a) Union Finance (exclusive of the railways and harbours).The following is a comparative summary of the gross ordinary revenue and cxpencliture of the Union for the twelve-year period:

\begin{tabular}{|c|c|c|c|c|c|c|}
\hline \multicolumn{3}{|c|}{ Year. } & Revenue. & Expenditure. & Surplus. & Deficit. \\
\hline 1910.11 & $\ldots$ & $\ldots$ & $14.418,23 \mathrm{i}$ & $13,593,207$ & 825,029 & \\
\hline 1911.12 & . . & . & $17.228,418$ & $16,5+7.381$ & 681,037 & \\
\hline $1912-13$ & . & . & $17,292,520$ & $17,064,387$ & 228,133 & \\
\hline 1913.14 & . & . & $15,805,07 t$ & $16,492,612$ & & 687,536 \\
\hline $1914-15$ & . & . & $14,265,096$ & $16,253,1+0$ & & $1,988,044$ \\
\hline $1915-16$ & . & . & $16,556,397$ & $16,158,479$ & 397,918 & \\
\hline $1916-17$ & . & . & 18.408 .615 & $17,8+5,377$ & 563.238 & \\
\hline 1917.18 & . & . & $19,657,597$ & 18.959 .198 & 698.399 & \\
\hline $1918-1 !$ & . & . & $21,911,029$ & $21,322,142$ & 588,387 & \\
\hline $1919-20$ & . & . & $26,885,957$ & $24,425.5331$ & $2.460,426$ & \\
\hline 1920.21 & . & $\ldots$ & $29,676,186$ & $30,075,71 t$ & & 399,530 \\
\hline 1921.2 .2 & . & . & $28,881,270$ & $30,091,023$ & & $1,206,75: 3$ \\
\hline & & & $40,989,3: 17$ & $238,628,19: 3$ & $6.443,067$ & $4,281,863$ \\
\hline
\end{tabular}

Thus there was a net surplus of $f 2,161,204$ over the twelve-year period from 1910 to 1922 . There were deficits in four years, viz. $1913-14,1914-15,1920-21$ and 1921-2.2.

If the year $1911-12$ is taken as the hasis for comparison instead of 1910-11 in view of the fact that the latter was not a full year (from 31 May, 1910 to 3list Mareh, 1911), the expenditure was inereased by 83 per cent. and the revemue by 68 per cent., whereas the population was subject to an increase of 20 per cent only.

The main causes of the considerable advance in the eurrent expenditure are the following: 
(1) the interest on the war debt which amounts to iblout $£ 1 \frac{1}{2}$ million per annum ;

(2) military pensions which occasioned an cxpenditure of $£ 1,273,036$ in $1920-21$;

(3) the Union Defence Foree which receives an annual appropriation of about $f 1 \frac{1}{4}$ million out of the current revenue;

(4) war bonuses to govermment employees which took up the amount of $£ 1,770,957$ in $1920-21$ :

(5) increases in salaries and wages which cnhanced the expenditure to the extent of several million pounds per annum ;

(6) enlargement of staff in all the departments of the Truion Government (excluding the Department of Railways and Harbours) from 31,000 in 1911-12 to 38,000 in 1920-21in conjunction with the rise in salaries and wages the enlarged staff caused an increase in the expenditure from

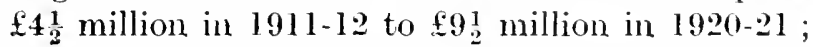

(7) the higher prices of materials and requisites which the Goverument has to purchase each year in conncetion with its activities.

The enhancement of the expenditure necessitated the extension of existing forms of taxation and the introduction of new forms. The customs duties on spirits, ale, beer, cider, coffee, tea, sugar, boots and shoes, etc., were increased, and the general ad valorem rate was raised from 15 to 20 per cent. The excise duties on spirits and beer were increased on three occasions since 1913, viz., in 1916, 1919 and 1921, and the excise duty on cigarettes which prevailed in the Cape of Good Hope was extended to the other thrce provinees. The stamp duties were also increased.

In addition, a whole series of new taxes has been introduced since the establishment of the Union, such as excise duties on sugar, tobacco, matches, playing cards and vinegar, income tax (including the super-tax and dividend tax), exeess profits tax, and the diamond export duty.

Up to 1920 the inerease in expenditure was generally mole than covered by increased taxation and the greater productivity of taxation as the result of favourable conditions in agriculture, industry, mining, trade and commerce. In 1920-21, however, the expenditures increased more rapidly than the revenues, and

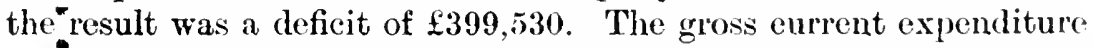

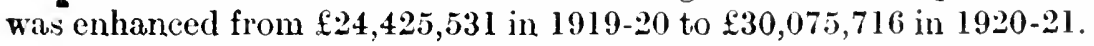
This great increase of $\mathfrak{f 5}_{2}^{1}$ million was due mainly to a further rise 
in salaries, war bonuses and prices, and also to an increase in the public debt charge, provincial subsidies, military pensions, etc.

The gross revenue was also enhanced but not to the same extent

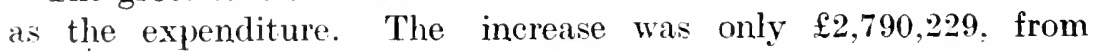
$£ 26,885,957$ in $1919-20$ to $£ 29,676,186$ in $1920-21$. The customs and excise yielded a net increase of $£ 2,379,205$ mainly as the result of increased importation and the enhanced value of imports, and the posts, telegraphs and telephones an increase of $\mathfrak{\$ 1 1 5 , 5 1 2}$ due to higher rates and charges; but inland revenue showed a decrease of $£ 4,487$, whereas an increase of $\mathfrak{2} 2 \mathbf{2 0 , 0 0 0}$ was estimated, the reason for the discrepancy being the initial effects of the general coonomic depression which set in toward the end of 1920 .

In the science of finance there is a maxim that in times of inflation and prosperity the Government should do everything in its power to restrain the increase in expenditure and to provide for a substantial surplus, so that when the time of depression and deflation arrives. the margin between the revenue and expenditure is wide enough to cover the consequent diminution of the revenue and perhaps even to permit of a reduction of the more obnoxious taxes. The state is. as a general rule, not capable of bringing about economy and retrenchment immediately and effectively, and accordingly strict and rigid control over the expenditure is the first requisite of an adequate fiscal system, especially in time of war. And this is where our otherwise good system of financial administration was defective.

The depression found the expenditure fully on a level with the revenue. The was no favourable margin as a reserve. No provision was made for the depression which was an inevitable consequence of the World War. The enhanced expenditure of the war period had rendered increased taxation necessary, and when the favourable economic conditions of 1919 and 1920 brought more revenue into the Treasury than was estimated, the abundance of revenue gave rise to still greater expenditure. The Government departments wore extended, the staff unduly enlarged, high war bonuses awarded and salaries excessively raised.

The depression hit the Treasury hard because (1) certain revenues were considerably diminished, (2) the gross eurent expenditure could not be reduced, (3) there was no favourable margin between the revenue and expenditure to offset the diminished revenue, and (t) the Government had already resorted to practically every arailable source of revenue. 
The revenues which were most adversely affected by the depression were $(a)$ the customs revenue which declined from $£ 9,015,875$ in $1920-21$ to $£ 5,292,786$ in $1921-22$, due to the decreased importation and the decline in the value of imports, $(b)$ the revenue from diamonds and diamond mines, such as the Government's share of the profits of the Premier Diamond Mine which yielded only $£ 54,213$ as compared with $£ 799,797$ in $1920-21$, the revenue from the export duty on diamoinds which fell from $\mathfrak{E} 810,463$ to $£ 142,559$, and the yield of the nurmal income tax on diamondmining companies and of the dividend tax on the dividends distributed by such companies which was likewise subject to a large reduction, and $(c)$ the revenue from stamp duties and fees which declined from $£ 1,017,844$ in $1920-21$ to $£ 874,764$ in 1921-22.

There was no net reduction in the gross expenditure in 1921-22 in spite of the efforts to secure economy and retrenchment. The war bonus was gradually eliminated, the purchase of materials was restricted, etc. However, the increase in the public debt charge, provincial subsidies, defence, posts, telegraphs and telephones, etc., and the provision for unemployment to the extent of 1399.84 ; occasioned a net increase of about $£ 15,000$ in the expenditure.

The following measures were taken in order to meet the diminution of the revenues referred to above and the net increase in expenditure in 1921 :

(1) The excise duties on spirits were increased by $2 \mathrm{~s}$. 6d. per proof gallon, so that wine brandy was rendered subject to an excise duty of $12 \mathrm{~s}$. 6d. per gallon, grape brandy $17 \mathrm{~s} .6 \mathrm{~d}$. and dop brandy $£ 12 \mathrm{~s} .6 \mathrm{~d}$, ; and the duties on beer were raised from $12 \mathrm{~s}$. and $£ 14 \mathrm{~s}$. per 36 gallons to $15 \mathrm{~s}$. and $£ 110 \mathrm{~s}$. respectively.

(2) A new excise duty was imposed on tobacco manufactured in the Union for sale, ranging from $6 \mathrm{~d}$. per $\mathrm{lb}$. of tobacco in the form of roll tobacco to ls. per lb. of tobacco ready for use in the making of cigarettes or for smoking in a tobacco pipe. and to $2 \mathrm{~s}$. $6 \mathrm{~d}$. per $1 \mathrm{~b}$. of tobacco in the form of cigars. (These rates, however, were reduced in 1922.)

(3) The customs duties on spirits, beer and tobacco were increased to countervail the increased excise duties, as also the duty on films for bioscopes.

(4) A special effort was made to collect a large portion of the arrear income and excess profits taxes, and the income tax was rendered applicable to the increase in the value of livestock and produce held by a farmer. 
(5) Certain loan revenues were diverted from the loan aceount to the revenue aecount, such as the proceeds of the sales of Crown lands and the revenue from the Government gold mine leases and the "bewarplaatsen."

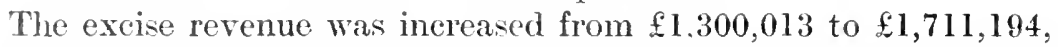

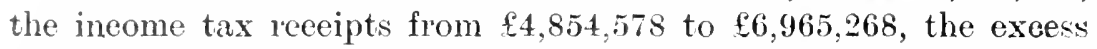

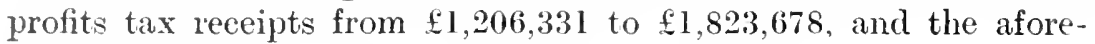
mentioned loan revenues amounted to $£ 934,106$.

However, the inerease in these revenues was not sufficient to offset the diminution of the other revenues, and the year 1921-22

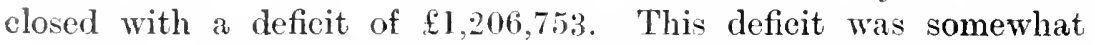
reduced in view of the fact that it was resolved to eredit to the Revenue Account the sum of $\$ 460.426$ ont of the net surplus of $\mathfrak{2}, 460,426$ of the year $1919-20$.

The current financial year 1922-23 is also expected to close with a fairly large defieit in view of the diminished vield of the ineome and excess profits taxes and the delay in the revival of agrieulture, industry, trade and diamond-mining. The Government has resolved to apply economy and retrenchment as far as possible, and the amount of the defieit will depend on the extent to which that ean be realised.

Public Debt.-The Union Government commenced in 1910 with a gross debt of $£ 116,036,978$, which was increased to $£ 191,784,936$ by Mareh 3 lst, 1922-an increase of 65 per cent. during the twelveyear period. The eapital expenditures during this period anounted

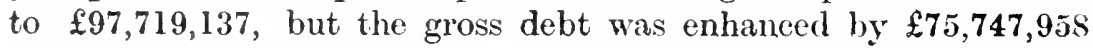
only, as the result of $(a)$ the appropriation of the loan revenues from the gold-mine leases, "bewaarplaatsen;" sales of Crown Lands and of surplus war material and supplies, repayments of advances made to the Provinces, irrigation boards, land settlers, universities and eolleges, local authorities, etc., and (b) the occasional redemption of loans out of the Sinking Fund.

The capital expenditure of $£ 97,719,137$ was distributed as follows: $£ 33,004,801$ for railways and harbours, $£ 32,393,452$ for the War and the Rebellion, $\mathfrak{1 2}, 179,669$ for land settlement, irrigation and the Land Bank, $£ 9,351,989$ in loans to the Provinces

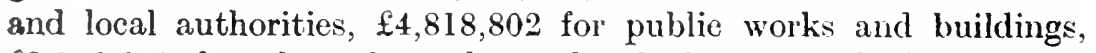

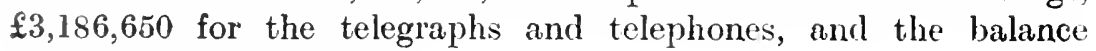
for miscellaneous items.

By adopting the incidence of the interest eharges as the only appropriate basis for determining the relation between the reproductive and the unproduetive debt, the public debt of the Union on the 
31st March, 192:- was found to be eomposed of a leproductive debt of $\mathfrak{f} 120,824,510$ and an unproductive debt of $\{70,96(1), \mathfrak{2} 26$, or 63 and 37 per cent respectively.

The real net debt of the Union can be obtained by deducting from the gross debt of $\mathbb{1} 191,784,936$ :

(1) the reproductive debt of $\{120,8 \div 4,510$;

(2) the amount of $£ 11,575,502$ in the sinking Fund; ind

(3) the balance of $£ 3,160,000$ on the loan atecount.

Thus the net debt of the Union on March 31st. 192.2. amomnted

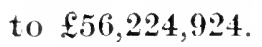

(b) Railway and Harbon Finance.-The following is at conparative summary of the gross earnings and expenditure of the Union railways and harbours (including steamships in operation since 1919) during the period under consideration:

\begin{tabular}{|c|c|c|c|c|c|c|}
\hline \multicolumn{3}{|l|}{ Year. } & $\begin{array}{c}\text { Earnings. } \\
£\end{array}$ & $\begin{array}{c}\text { Exprenditure. } \\
£\end{array}$ & $\begin{array}{c}\text { Surplus. } \\
\mathfrak{f}\end{array}$ & $\begin{array}{c}\text { Defì.it. } \\
\pm\end{array}$ \\
\hline 1910.11 & . & $\ldots$ & $11,184,757$ & $9,589,365$ & $1,595,392$ & \\
\hline $1911-12$ & . & $\ldots$ & $13,226,666$ & $11,686,608$ & $1.540,058$ & \\
\hline 1912.13 & .. & . & $13,316,800$ & $13,436,147$ & & 119,347 \\
\hline 1913-14 & .. & . & $13,484,375$ & $14,012,141$ & & 527,760 \\
\hline 1914.15 & .. & . & $12,829,863$ & $13,373,659$ & & $5+3,796$ \\
\hline $1915 \cdot 16$ & . & . & $13,768,736$ & $12,411,379$ & $1.357,357$ & \\
\hline $1916 \cdot 17$ & . & .. & $14,899,864$ & $14,909,457$ & & 9,593 \\
\hline $1917-18$ & . & .. & $15,726,613$ & $15,957,879$ & & 231,266 \\
\hline $1918 \cdot 19$ & . . & . & $16,712,979$ & $17,700,646$ & & 987,667 \\
\hline 1919.20 & . & . & $20,854,877$ & $21,453,775$ & & $598,89 \mathrm{~s}$ \\
\hline 1920.21 & .. & .. & $26,243,476$ & $27,293,166$ & & $1,049,690$ \\
\hline 1921.22 & . & . & $22,532,765$ & $24,123,256$ & & $1,590,491$ \\
\hline & & - & $94,781,771$ & $195,947,478$ & $4,492,807$ & $5,6.58,01+$ \\
\hline
\end{tabular}

Thus there was a net deficit of $£ 1,165,707$ over the period from 1910 to 1922. However, in view of the fact that the sum of $\mathfrak{f 3 , 1 7 9 , 0 0 0}$ was paid to the Union Treasury out of the profits of the railways and harbours during the first three years of the Union. the Department of Railways and Harbour's was faeed with an accumulated deficit of over 4 million pounds on the 31 st March, 1922. And it must also be taken into consideration that, during those three years, substantial contributions were made to the Betterment and Renewals Funds of the Railways and Harbours out of the revenue account in view of the considerable net operating income. These contributions and the amount paid over to the Union Treasury for the current expenditure of the Government would have been more th an sufficient to meet the long serjes of deficits sinee 1916. 
In 1915-16 the profit was more fictitious than real since it was obtained mainly by a'reduction in the ordinary appropriations for depreeiation and renewals. The railway earnings were adversely affected by the disturbance in trade and traffic oceasioned by the routbreak of the European War and the South African Rebellion, and it was decided to offset the diminution of the earnings by a reduetion in the expenditure on depreeiation and renewals which

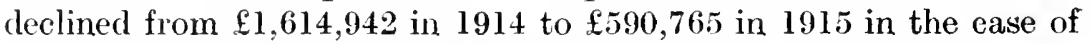
the railways, and from $£ 184,735$ to $£ 46,504$ in the case of the harbours. However, the revival of trade and industry brought about an inerease in the revenue, the year 1915-16 yielding a surplus of $\{1,357,357$. Accordingly, a special appropriation of $£ 958,497$ was made to the Renewals Fund in 1916, the result being a defieit of 99.593 in 1916-17.

The Railway and Harbour Administration ineurred the error of disposing of practically all the large profits obtained during the first three years of the Union. An Equalization Fund was instituted to maintain uniformity of rates over a long period and meet any deficits that may occur, but the amount available in the time of need was so small that it was speedily absorbed. The Administration could not be blamerl for not having predicted the World War and its dimensions and effeets, but it would certainly have been more advisable to ereate a strong contingeney fund at the start when the surplus earnings were available. But the Parliament was justified in authorising, during the session of 1922 , the transfer of $£ 2,000,000$ from the renewals fund towards meeting the deficit incurred up to March 31st, 1922, in view of the contributions to that fund from the profits of the favourable years, thus reducing the aeeurnulated deficit to $£ 2,189,374$.

The expenditure was more than doubled during the period under review, partially as the result of the extension of the railway net from 7,041 miles of line in 1910 to almost 10,000 in 1922 and the denser traffic, but mainly due to the increased cost of living and of materials. The war bonus was introduced in 1916 and was"extended until it was of general applieation in 1918. The salaries and wages were appreeiably increased in 1919 and 1920, and in addition the 8-hour day was instituted. These three factors enhanced the expenditure of the railways and harbours by several million pounds per annum.

The two great diffieulties which confronted the Administration sinee the ontbreak of the War were (1) how to eover the rapidlyncreasing expenditure, and (2) how to diminish the expenditure 
according to the decrease in earnings since the seeond half of 1920 . as the result of the economic depression.

The Administration first resorted to the suspension of exeursion pacilities and the levy of a sureharge on coal for bunkering purpose-, and of a terminal charge on all kinds of goorls traffic, and then took to increasing the passenger fares and gencral freight rates on four or five different occasions until toward the end of 1920 the average inerease was about 58 per eent. above the pre-war rates. This was the turning point and the railway traffic could not bear any further increase in rates. The depression brought about a decrease in traffic and consequently in earnings. and the prevailing high rates contributed towards the further diminution of traffic.

Aceordingly, the Administration deeided to reduce the expenditure by gradually eliminating the war bonus and discharging a portion of the staff, and also to reduce the rates in certain necessary cases, e.g., bunker and export coal, grain. cement, guano, etc. The railways are now in the middle of a transition period. The expenditures must be brought on a normal hasis and the rates fixed accordingly.

The expenditure of the railways, harbours and steamships wareduced from $\{27,293,166$ in $1920-21$ to $\{24,123.2 .56$ in $1921-22$, and further attempts are being made during the eurrent financial year (1922-23) to economise and reduce expenses, but in view of the slow recovery of trade and industry the year is expected to close with a loss and add one more to the long list of deficits.

(c) Provincial Finance.-Provineial finance as such dates from April 1, 1913. From the date of the constitution of the Union until April, 1913, when the Financial Relations Aet came into operation, all the funds required by the Provinces were provided by grants from the Union Exchequer.

The following is a comparative summary of the gross current revenue and expenditure of the Provinces since 1913-14:

\begin{tabular}{|c|c|c|c|c|c|c|}
\hline \multicolumn{3}{|l|}{ Year. } & $\begin{array}{c}\text { Revenue. } \\
\mathfrak{E}\end{array}$ & $\begin{array}{c}\text { Expenditure. } \\
\pm\end{array}$ & Sirplus. & 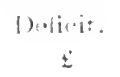 \\
\hline $1913-14$ & . & . & $3,482.190$ & $3,324,136$ & $1,59,054$ & \\
\hline 1914-15 & $\ldots$ & . & $3,341,519$ & $3.346,142$ & & $4 .+24$ \\
\hline $1915 \cdot 16$ & . & . . & $3,204.194$ & $3,365,70.5$ & & {$[61.511$} \\
\hline 1916.17 & . & . & 3.769 .183 & $3,708,684$ & $n(0,+4: 4$ & \\
\hline $1917 \cdot 18$ & . & . & $4,334,484$ & $4,255,051$ & $79.43: 3$ & \\
\hline $1918-19$ & .. & . & $5,122,178$ & $5,212,710$ & & $\{0,53: 3$ \\
\hline $1919-20$ & .. & . & $7,058,715$ & $6,388,05 \pm$ & 6713,663 & \\
\hline $1920-21$ & . & . & 8.074 .764 & $8,417,256$ & & 342.492 \\
\hline 1921.22 & . & . & $8,358,44 !$ & $8,798,400$ & & 439,951 \\
\hline & & . & $46,745,675$ & $46,816,134$ & 965.1519 & $1,9: 39.110$ \\
\hline
\end{tabular}


Thus there was a net deficit of 50,461 over the nine-year period. There were deficits in 5 years, namely 1914-15. 1915-16, 1918-19, $1920-21$ and $1921-22$.

The exceptional advance in the expenditure from $\{3,324,136$ in 1913-14 to $\$ 8.798,400$ in 1921-22 rendered the increase of old taxes and the introduction of a whole serics of new taxes necessary. The sources of revenue which were transferred to the Provinces under the Financial Relations Act, such as licences, anction dues, totalisator tax, educational and hospital fees, etc., were made to field $f 1,242,247$ in $1920-21$ as compared with $\mathfrak{E} 641,581$ in 1916-17. In addition. more than a dozen new taxes were introduced in one or more of the Provinces during the period under consideration, as follows:

Taxes on.

(1) Admission to Racecourses

(2) Bachelors

(3) Betting

(4) Bookmakers

(5) Companies . .

(6) Crayfish Canning Companies

(7) Entertainments .. . .

(8) Excess Profits .. . .

(9) Gold Mines Profits

(10) Houses

(11) Increment Value . .

(12) Polls (Poll Tax) .. ..

(13) Property . . . . .

(14) Tattersalls , . . . . .

(15) Wheels $\ldots$.. . .
Provinces and Years in which Taxes introduced.

Transvaal (1920).

Transvaal (1917)-repealed in 1920.

Cape (1920).

Transvaal (1917) and Cape (1920).

('ape (1920).

Cape (1920)-repealed in 1921.

. Natal and O.F.S. (1917). Cape (1918).

. Transraal (1917)-repealed in 1919.

. Transvaal (1918)-repealed in 1921.

. Transvaal (1917)-repealed in 1920.

. Transvaal (1919)-repealed in 1920.

. Transvaal (1921).

. Cape (1920).

.. Transraal (1918).

. Transvaal, Natal and O.F.s.

.. O.J.S. (1921).

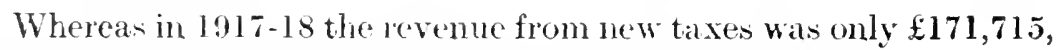
by 1920-21 they were cxtended so as to rield $11,013.445$.

The enhancement of the current expenditure of the Provinces by 165 jer cent. during the nine-year period is due mainly to the considerable increase in the expenditure on education from $£ 2,065,407$ in $1913-14$ to $\mathfrak{f} 6,654,373$ in $1921-22$, which again is to be attributed partly to the extension of educational facilities and the increase in the number of schools from 6,600 in 1913 to over 8,000 in 1922 and in the number of teachers from 13.000 to 19,000 , but mainly to the rise in salaries as the result of the increased cost of living and to the higher prices of materials and requisites. There was also a substantial advance in the expenditure on general administration, roads, bridges, hospitals and poor relief. 
During the last five years the great problem of the Provinedal Administrations has been how to eover the rapidly increang expenditure with the limited sonrees of revenue at their di-ponal. Under the Union Constitution and the Financial Rolation. Act the Provinees have been entrusted with aetivities and functions which necessarily entail an inerease in expenditure from roale to year, whereas they are practically confined to stationary sources of revenue. The result has becm that the Proviness have hat to search for new sources every year in their attempt to cover the increased expenditure. The Provinces have now reached a stage where they cannot impose additional taxation without incurring riolent opposition. They have exhanted almont erery available source of revcmute.

In 1922 the Cape Province attempted to introduce a sales tax and the 'Transvaal an employer's' tax, in view of the fact that the yeir $1921-22$ elosed with a deficit of $£ 108.090$ in the case of the (ape and that the Union subsidy was diminished. The sales tax aromed such vehement resistance from the husiness interests that the Cape Administrator was obliged to abandon the project and accept an advance of $£ 200,000$ from the Union Government.. The Provincial Council in the Transvaal, however, persisted and introluced legislation providing for the imposition of the employer tax.

The prevailing system of provincial finance needs to be revised. The Provinces must either be relieved of certain functions and consequently of certain expenditures, or a substantial new rource of revenue must be assigned to the Provinces. The latter appeari to be the better alternative. In order to minimize the evil and disadvantages inherent in a system of subventions from the central government, such as the inducement to extravagance resulting from the receipt of money from an outside source, it seems to be adrisable to reduce the ordinary Union subsidy to one-third of the normal or recurrent expenditure of a Province and in lieu of that to assign certain new sources of revenue to the Provinces, e./.. estate and succession duties, stamp duties, and native taxes. 'The right to legislate in regard thereto must be retained by the Union Pirliament, but the revenue assigned to the respective Provintes.

The Union Government has reeently appointerl a commin-mion to institute an inquiry into the whole system of provincial finances and to make recommendations as to the necessary molification- and alterations to be made. It is hoped that the commision will be able to bring about the desirable readjustment and an effective system of financial relations between the Union and the Provinces. 
Summary.- The results of the financial operations for the entire period from May 31st, 1910 to March 31st, 1922, may be summed up an follows:

$$
\text { Heading. }
$$

Union

$\begin{array}{lllllllllll} & \cdots & \cdots & \cdots & \cdots & \end{array}$

Railways and Harbour . . . . .

$\begin{array}{llllll}\text { Provinces } & \text {. } & \ldots & \ldots & \ldots & \ldots\end{array}$

Total . $\quad . \quad \ldots$

Net sumplus..
Surplus.

$\mathfrak{f}$

$2.161,204$

$2,161,204$

$1,236,168$

$£ 925.036$
Deficit.

$\mathfrak{f}$

$1,165,707$

70,461

$1,236,168$

Taking into consideration the fact that, in the above calculation, the sum of $\$ 3,179,000$ appeared twice, viz., as railway and harbour surplus in 1910-11 and 1911-12 and as Union revenue in 1910-11, 1911-12 and 1912-13, and that accordingly that amount is to be deducted from the net surplus which was computed in respect of all the financial operations of the Union and the Provinces, the result was a net deficit of $\mathfrak{f 2}, 253,964$. 


\section{INDEX.}

\begin{tabular}{|c|c|c|c|c|c|}
\hline & & & & & \\
\hline & & $198,201,206$ & Erlucation, ngrieulture & & \\
\hline inistrator & & $4,12,205,214$ & primary and se & ietondte & lary \\
\hline dministration of $\mathrm{l}$ & "inane & $\operatorname{ces} 8,9,192,225$ & higher .. & . & \\
\hline inistrative Rev & benne & $9,121,220,222$ & Education "Tax & . & \\
\hline o Racec & course & . 171 & Elections. expenditure & . & 14. \\
\hline ture, ex & liture & $\ldots+2$ & Amployers' 'Tax & . & 173.23 \\
\hline ffairs & . & 13 & Entertainment 'Tax & . & $\ldots 16$ \\
\hline $\mathbf{y}$, House of & . & $\ldots .2,12,201$ & Outy & . & $\ldots 15$ \\
\hline Revenues & $\ldots$ & $\ldots \quad \ldots 190$ & Est & $\ldots$ & .. 20 \\
\hline my $\quad \ldots$ & . & 14, 16 & Excess Profits 'Tux .. & . & 142.14 \\
\hline Tax & $\cdots$ & .. 171 & $\mathrm{Ex}$ & . & . 19 \\
\hline feneral & .. & . 5. 20.209 & $\begin{array}{c}\text { Excise Department } \\
. . \quad \text { Duties }\end{array}$ & $\begin{array}{l}\cdots \\
\cdots\end{array}$ & $\begin{array}{r}2(1.19 \\
\ldots .13\end{array}$ \\
\hline $\mathrm{ax}$ & .. & . 170 & e Committae & . . & \\
\hline Duty & . & .. 161 & Expenditures & . . 8. & 11. 21 \\
\hline Mines & . & . 109 & & & \\
\hline Beer, c & & . 127 & Fees & & 12 \\
\hline$\ddot{\epsilon} \epsilon$ & & . . 133 & Financial Administration & $\cdots$ & $\therefore \quad=$ \\
\hline Bew & & . 108 & Finaneial Relations Art & $8,13$. & .24 .18 \\
\hline oo & 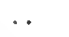 & $\ldots 171$ & Fines and For & . & $\ldots 12$ \\
\hline ric & & 22 & Forest & & \\
\hline 1 & & 9.201 & German South-West Afrid & ican C & \\
\hline ig & & . . 133 & & & . \\
\hline as & & & iold Mines, di & & . 14 \\
\hline 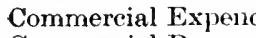 & ditu & es .. & . & & $\ldots 10$ \\
\hline $\mathrm{R}$ & nes & 18,222 & $\tan$ & & . . 1 \\
\hline s & & . & levy & . & $\ldots 15$ \\
\hline $\mathrm{Ca}$ & $D_{1}$ & .. 161 & or-General & 1,11 & 207,21 \\
\hline $\operatorname{Pr}$ & cial & $\ldots 172$ & nent Gold Mining & Areas & .. 10 \\
\hline ion & Wance & 18,28 & lands & $\cdots$ & $\ldots 11$ \\
\hline or & ater & $\because \quad \ldots 111$ & Gunrdians" Fund & . & \\
\hline Rev & nue $\mathrm{F}$ & Fund $5,11,195$ & & & \\
\hline & & ind and & He & $\because$ & 8, \\
\hline & & . & High Commi & & \\
\hline or & & $\begin{array}{l}8,9,206 \\
\end{array}$ & Educat & & $\cdots$ \\
\hline 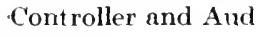 & litor & neral & $\mathrm{Hc}_{\mathrm{c}}$ & . & 48,12 \\
\hline & & $5,20,209$ & Ho & & .. 10 \\
\hline & . & .. 31 & & & \\
\hline & . & . & & & \\
\hline & . & . & ty $\mathrm{T}$ & & $\ldots 17$ \\
\hline$u$ & & 20,19 & & . & $\ldots 12$ \\
\hline P & & . 125 & Cont & ants & \\
\hline & & 75,230 & 15 & $\operatorname{tax}$ & .17 \\
\hline Def & . & 25 & $l_{1}$ & .. & \\
\hline tal $R$ & ipts & - 123 & . & & 57.21 \\
\hline De & fect & re Classes .. 48 & ion a & & \\
\hline Iine & i. & . 142 & & 80 & 1 of \\
\hline & & re 104 & & & 19. 19 \\
\hline & cofit & $\operatorname{tax}$ & Duty & . & .. 10 \\
\hline & duty & .. 1 & ent of & $\cdots$ & 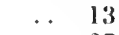 \\
\hline & . & $\ldots$ & & & $\cdots$ \\
\hline & & 93,21 & es .. & & \\
\hline Cast Rand Mines & & 10 & enue $\mathrm{i}$ & & 19. \\
\hline
\end{tabular}




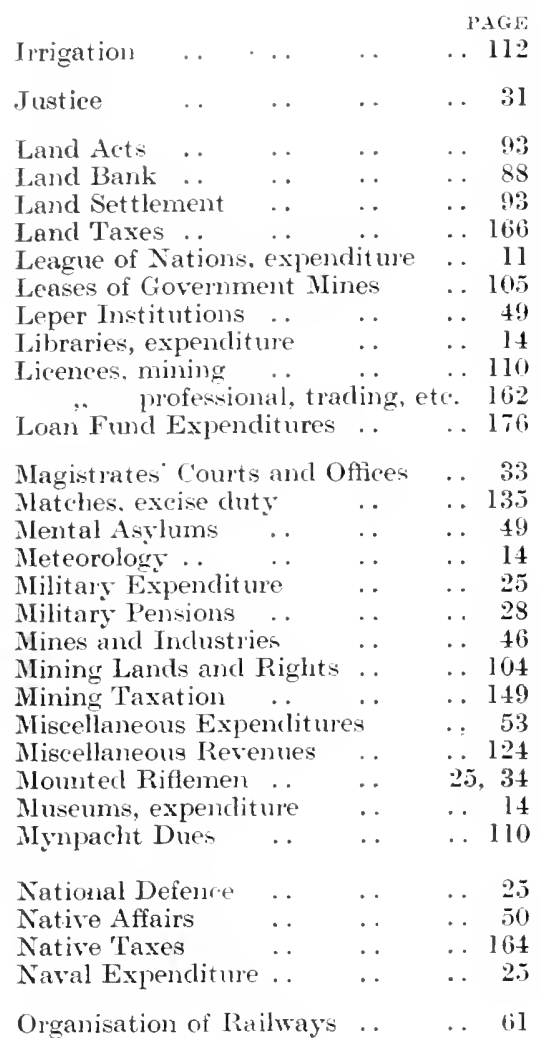

Parliament, powers of 3. 201, 206 $\because$ expenses $\quad$. $\quad \ldots \quad 12$ .. $\quad \ldots 16$. $\begin{array}{lllll}\text { Penquin eggs } & \ldots & \ldots & \ldots & 116 \\ \text { Pensions, civil } & \cdots & & & 16\end{array}$ ,. military .. $\quad$. $\quad$.. 28 Playing Cards, exeise duty. . . 135 $\begin{array}{llllll}\text { Police } & \ldots & \ldots & \ldots & \ldots & 33\end{array}$ $\begin{array}{lllll}\text { Poor Relief . . } & \ldots & \ldots & \ldots & 49\end{array}$

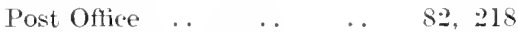
Premier Diamoni Xline . . . . 104 Primary Education . . $\quad$. 37 Prime IInister _. . . $\quad$. . 11 Printing and Stationery $\quad$. $\quad$.. 13

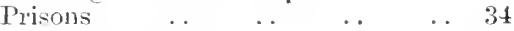
Provincial Arministrations _. 12 Auclit .. Council .. 4. 12. 205, 214 Excess profits Tax .. 148 Gold Profits Tax _. 154 Revenue Fund .. 5, :000 $\begin{array}{llll}\text { Subsidies } & \ldots & \ldots & 186\end{array}$ Taxation 168. 190. 234 Prussian Railways .. . . . . 60 Public Accounts Committee .. 211 Public Debt.. 8, 52, $175,224,230$
Publie Diggings

Public Health

Public Works and Buildings 21, 176

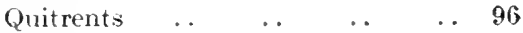

Railways $\quad \ldots \quad \ldots \quad 58$, 1, 231

Railway Board _. $\quad$. $\quad \ldots, 58$

Railway and Harbour Fund $\cong, 199$

Rebellion $\quad \ldots \quad \ldots . \quad \ldots 27, \mathbf{2 8}, 30$

Receivers of Reventie $\quad \ldots \quad 195,201$

Redemption .. $\quad \ldots \quad$. $\quad 52,179$

Reformatories $\quad . . \quad \ldots . \quad \ldots \quad 34$

Registration of Deeds $\quad \ldots \quad \ldots 54$

, of Doters $\quad \ldots \quad 13,15$

Rents of Crown Lands . . . . 97 , of Govemment Houses and

Buildings 124

Revenues $\quad \ldots \quad$. $\quad 8,57,218$

Roads, pxpenditure $\quad \ldots \quad \ldots 22$

$\begin{array}{lllll}\text { Sales Tax } & \ldots & \ldots & \ldots & \ldots 235\end{array}$

$\begin{array}{lllll}\text { Savings Bank } & \ldots & \ldots & \ldots & 87\end{array}$

School Fees . $\quad \ldots \quad$. . $\quad \ldots 121$

Seal Skins $\quad \ldots \quad \ldots \quad \ldots \quad \ldots \quad \ldots 116$

Secondary Education $\quad \ldots \quad \ldots 37$

$\begin{array}{lllll}\text { Senate } \quad \ldots & \ldots & \ldots & 2,12\end{array}$

Sinking Fund $\quad \ldots \quad \ldots 180$

South Africa Act $1,22,32,37,48$

$54,58,77,185$

Spirits, customs duty $\quad$. $\quad \ldots 127$

, excise duty . . $\quad \ldots \quad \ldots 132$

Stamp Duties _. $\quad \ldots \quad$. 160

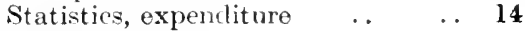

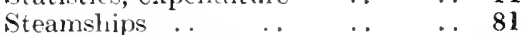

Succession Duty $\quad \ldots \quad \ldots \quad \ldots \quad \ldots 155$

Sugar, excise dut $\psi^{*} \ldots \quad \ldots \quad \ldots \quad \ldots 134$

Superamnution Allowances _. 18

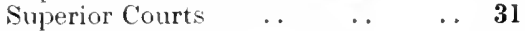

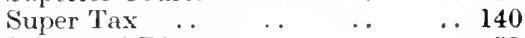

Survey of Diagrams $\quad$. $\quad \ldots \quad 53$

Swiss Railways . . $\quad$. $\quad \ldots 60$

$\begin{array}{lllll}\text { Tariff system } & \ldots & \ldots & \ldots & 126\end{array}$

Tattersall Tax $\quad \ldots \quad \ldots . \quad \ldots 173$

Taxation ... .. 9, 125, 220, 223

Telegraphs and Telephones $\quad \mathbf{8 2}, 218$

Tobacco, excise duty $\quad$. $\quad \ldots 134$

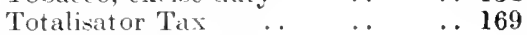

Trartes Commisioner _. $\quad$.. 18

Transfer Duty $\quad \ldots \quad \ldots \quad \ldots \quad \ldots 159$

Transferred Revenues _ . $\quad \ldots 189$

Treasury $\quad \ldots \quad \ldots \quad 20,192,206$

Universities .. $\quad \ldots \quad$. $\quad \ldots \quad 40$

Vinegar, excise duty $\quad \ldots \quad \ldots 134$

Water Boring $\quad$. $\quad \ldots \quad$.. 113

War Bonus .. . . . . . 215

., Expenditure .. 28, 30, 176

., Levy on Gold Mines .. .. 151

Whed Tax ..

Printed ly Cape tures limited, Cape Toun. 

UNIVERSITY OF CALIFORNIA LIBRARY

Los Angeles

This book is DUE on the last date stamped below.

$122136: 3$

Form $\mathrm{L} 9-30 \mathrm{~m}-11,{ }^{\prime} 58(8268 \mathrm{st}) 441$

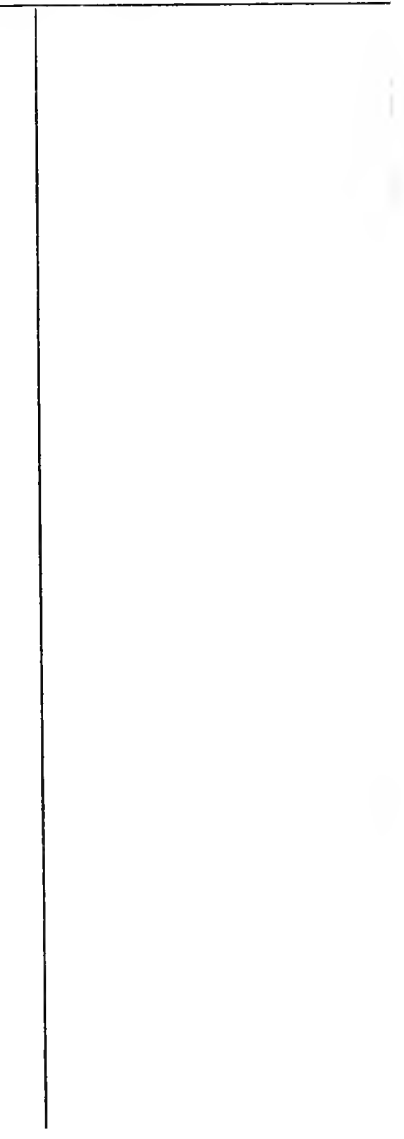




\begin{tabular}{|ll} 
HJ & De Kock - \\
\hline 1514 & Analysis of the \\
D369a finances of the & Anion of South \\
\hline 1922 & $\begin{array}{l}\text { Africa } \\
\end{array}$
\end{tabular}

$w^{R}$

16

UC SOUTHERN REGIONAL LIBRARY FACILITY

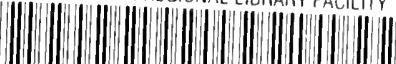

AA 0010277697

证

1514

D 3898

1922

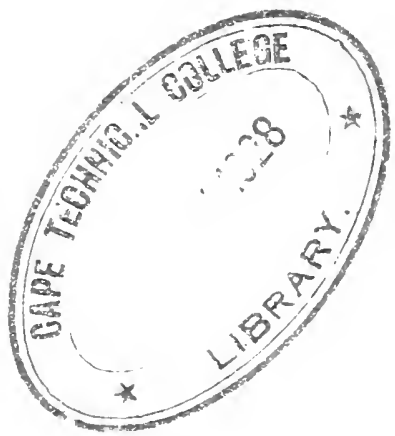


